Emerging-Economy State and International Policy Studies

Takashi Shiraishi

Tetsushi Sonobe Editors

\title{
Emerging States \\ and Economies
}

Their Origins, Drivers,

and Challenges Ahead 


\section{Emerging-Economy State and International Policy Studies}

\section{Series editors}

Tetsushi Sonobe, National Graduate Institute for Policy Studies, Tokyo, Japan Takashi Shiraishi, Prefectural University of Kumamoto, Kumamoto, Japan Akihiko Tanaka, National Graduate Institute for Policy Studies, Tokyo, Japan Keiichi Tsunekawa, National Graduate Institute for Policy Studies, Tokyo, Japan Akio Takahara, Graduate School of Public Policy, The University of Tokyo, Tokyo, Japan 
This is the first series to highlight research into the processes and impacts of the state building and economic development of developing countries in the non-Western World that have recently come to influence global economy and governance. It offers a broad and interactive forum for discussions about the challenges of these countries and the responses of other countries to their rise. The term 'emerging-economy state,' a part of the series title, or its shorthand 'emerging states,' is intended to promote dialogues between economists who have discussed policy problems faced by 'emerging-market economies' and scholars in political science and international relations who have discussed 'modern state formation.' Many emerging states are still in the middle-income status and not immune from the risk of falling into the middle-income trap. The manner of their external engagement is different from that of the high-income countries. Their rise has increased the uncertainty surrounding the world. To reduce the uncertainty, good understanding of their purpose of politics and state capacity as well as their economies and societies would be required. Although the emerging states are far from homogenous, viewing them as a type of countries would force us to understand better the similarity and differences among the emerging states and those between them and the high-income countries, which would in turn to help countries to ensure peace and prosperity. The series welcomes policy studies of empirical, historical, or theoretical nature from a micro, macro, or global point of view. It accepts, but does not call for, interdisciplinary studies. Instead, it aims to promote transdisciplinary dialogues among a variety of disciplines, including but not limited to area studies, economics, history, international relations, and political science. Relevant topics include emerging states' economic policies, social policies, and politics, their external engagement, ensuing policy reactions of other countries, ensuing social changes in different parts of the world, and cooperation between the emerging states and other countries to achieve the Sustainable Development Goals (SDGs). The series welcomes both monographs and edited volumes that are accessible to academics and interested general readers.

More information about this series at http://www.springer.com/series/16114 
Takashi Shiraishi - Tetsushi Sonobe Editors

\section{Emerging States and Economies}

Their Origins, Drivers, and Challenges Ahead

Springer Open 
Editors

Takashi Shiraishi

Prefectural University of Kumamoto

Kumamoto, Japan
Tetsushi Sonobe (iD

National Graduate Institute for Policy

Studies

Tokyo, Japan

\section{(9) $(\mathcal{Q} \Theta \Theta$}

ISSN 2524-5015

ISSN 2524-5031 (electronic)

Emerging-Economy State and International Policy Studies

ISBN 978-981-13-2633-2 ISBN 978-981-13-2634-9 (eBook)

https://doi.org/10.1007/978-981-13-2634-9

Library of Congress Control Number: 2018957249

(C) The Editor(s) (if applicable) and The Author(s) 2019. This book is an open access publication.

Open Access This book is licensed under the terms of the Creative Commons AttributionNonCommercial-NoDerivatives 4.0 International License (http://creativecommons.org/licenses/by-nc$\mathrm{nd} / 4.0 /$ ), which permits any noncommercial use, sharing, distribution and reproduction in any medium or format, as long as you give appropriate credit to the original author(s) and the source, provide a link to the Creative Commons licence and indicate if you modified the licensed material. You do not have permission under this licence to share adapted material derived from this book or parts of it.

The images or other third party material in this book are included in the book's Creative Commons licence, unless indicated otherwise in a credit line to the material. If material is not included in the book's Creative Commons licence and your intended use is not permitted by statutory regulation or exceeds the permitted use, you will need to obtain permission directly from the copyright holder.

This work is subject to copyright. All commercial rights are reserved by the author(s), whether the whole or part of the material is concerned, specifically the rights of translation, reprinting, reuse of illustrations, recitation, broadcasting, reproduction on microfilms or in any other physical way, and transmission or information storage and retrieval, electronic adaptation, computer software, or by similar or dissimilar methodology now known or hereafter developed. Regarding these commercial rights a non-exclusive license has been granted to the publisher.

The use of general descriptive names, registered names, trademarks, service marks, etc. in this publication does not imply, even in the absence of a specific statement, that such names are exempt from the relevant protective laws and regulations and therefore free for general use.

The publisher, the authors, and the editors are safe to assume that the advice and information in this book are believed to be true and accurate at the date of publication. Neither the publisher nor the authors or the editors give a warranty, express or implied, with respect to the material contained herein or for any errors or omissions that may have been made. The publisher remains neutral with regard to jurisdictional claims in published maps and institutional affiliations.

This Springer imprint is published by the registered company Springer Nature Singapore Pte Ltd. The registered company address is: 152 Beach Road, \#21-01/04 Gateway East, Singapore 189721, Singapore 


\section{Preface}

Since the turn of the twenty-first century, we have seen the emergence of new economic powers on an unprecedented scale and the concomitant rise of some states in regional and/or global affairs. Most of the emerging-economy states are still in the middle-income status. They are neither immune from middle-income trap nor status quoists as advanced industrialized democracies. Their future is full of uncertainties, both political and economic. Yet their rise is as significant a development as the rise of the "West" in the nineteenth century and will have enormous bearings on world affairs.

It is with this question in mind that we have assembled a group of economists, political scientists and historians and organized a joint research project. We have asked three sets of questions: what challenges the emerging states and economies face and how they are trying to meet them, what their long-term historical trajectories are, both political and economic, in modern times, and what lessons we learn from their rise for state building and economic development.

More than 50 academics, affiliated with universities or government think-tanks, have joined the group: economists who have been working on developing and emerging economies, political scientists who have examined developmentalist regimes and democratization in the non-"Western" world, and historians who have studied state formation and economic history in global and regional comparative perspectives. The four-volume Studies of Emerging-Economy State series, of which this book is the first to showcase our take on emerging states and economies, is an important product of our common endeavors. The series will include Paths to the Emerging State in Asia and Africa, which offers historical and contemporary case studies of the transition to an emerging state, Developmental State Building: The Politics of Emerging Economies which is an attempt to revisit and revitalize the notion of developmental state with more nuanced analysis of the role of human agency in structural transformation, and Emerging States at Crossroads, which analyzes economic, social, and political challenges emerging states and economies confront. 
In the course of the 5-year joint research, we have developed a lively forum for transdisciplinary dialogue, in which far more than our joint research project members participate. And we are pleased that the forum is now being boosted further by Springer Nature's new book series Emerging-Economy States and International Policy Studies, which seeks to publish monographs and edited volumes on a variety of topics related to emerging states and economies and policy studies.

Many people have contributed to the preparation of this and other books in the series as well as the slow maturation of the project itself. Particularly, we would like to thank Chris Baker, Peter J. Katzenstein, Taizo Miyagi, Keiichiro Oizumi, the late Cayetano Paderanga, Pasuk Phongpaichit, Osamu Saito, Hiroshi Nakanishi, and Akihiko Tanaka. Members of our research project who are not authors of chapters in this volume also gave us useful and valuable comments. We thank Caroline Sy Hau, Khoo Boo Teik, Yusuke Takagi, and Keijiro Otsuka among many others. The project has organized many seminars, workshops, and conferences over the 5 years at the National Graduate Institute for Policy Studies (GRIPS) and other places. We thank all participants and people who have made those seminars, workshops and conferences happen, especially GRIPS staff, including Akiko Ishikawa, Yu Ito, Eriko Kimura, Miori Maeda, and Yasuko Takano. We are also grateful to Jumpei Watanabe, Shiho Fujiwara, Toshihide Arimura, and Kengo Soga for advice about the project organization and management.

Funding for our project management and our studies included in this series was provided by Japan Society for Promotion of Science (JSPS) KAKENHI Grant Numbers 25101001, 25101002, 251004, 251005, 251006, and 15K21728. The support from KAKENHI Grant Number 25101002 made the Open Access publication of this series possible.

Kumamoto, Japan

Takashi Shiraishi

Tokyo, Japan

Tetsushi Sonobe 


\section{Contents}

1 Emerging States and Economies in Asia: A Historical

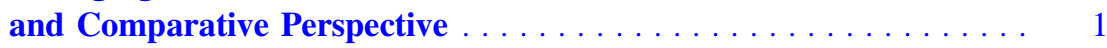
Takashi Shiraishi

2 Globalization and the Emerging State: Past Advance

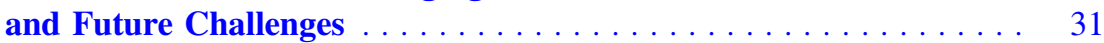
Keiichi Tsunekawa

3 The Asian Path of Economic Development: Intra-regional Trade, Industrialization and the Developmental State Kaoru Sugihara

4 Financing Colonial State Building: A Comparative Study of the 19th Century Singapore and Hong Kong Takeshi Onimaru

5 China's Emerging State in Historical Perspective R. Bin Wong

6 A History of the Indian Economy in Asian and Global Contexts, 1810s-2010s. Sugata Bose

7 Middle-Income Trap in Emerging States Tetsushi Sonobe 


\section{Editors and Contributors}

\section{About the Editors}

Takashi Shiraishi is Chancellor, Prefectural University of Kumamoto. He received his $\mathrm{Ph}$.D. in history from Cornell University and taught at the University of Tokyo, Cornell University, Kyoto University, National Graduate Institute for Policy Studies (GRIPS), and Ritsumeikan University. He served as Executive Member, Council for Science and Technology Policy (CSTP), Cabinet Office, President, GRIPS, and President, Institute of Developing Economies-JETRO. He also served as editor, Indonesia, Cornell Southeast Asia Program and editor-in-chief, nippon.com, a multilingual online journal. He was awarded the Medal with Purple Ribbon and designated to the Order of Cultural Merit. He was awarded the Medal of Bintang Jasa Utama from Indonesia. He is the author of three award-winning books: An Age in Motion (Ithaca: Cornell University Press, 1990, Ohira Masayoshi Asia Pacific Award), Indonesia: Kokka to Seiji (Government and politics in Indonesia, Tokyo: Libroport, 1990; Suntory Academic Award), and Umi no Teikoku (Empires of the seas, Tokyo: Chuokoron, 2000; Yomiuri-Yoshino Sakuzo Award). His recent works include Chugoku wa Higashi-Ajia wo Do'o Kaeruka (How is China changing East Asia? Tokyo: Chuo Koron, 2012, coauthored with Caroline Sy Hau), and Kaiyo Ajia vs. Tairiku Ajia (Maritime Asia vs. Mainland Asia, Kyoto: Minerva, 2016).

Tetsushi Sonobe is Vice President of National Graduate Institute for Policy Studies (GRIPS) and a development economist. His scholarship has contributed to a deeper understanding of industrial clusters, business management, public service delivery, and industrial development in developing countries based on a number of case studies conducted in Asia and Africa. Before joining GRIPS, he was a professor of economics at Tokyo Metropolitan University and a senior researcher at the Foundation for Advanced Studies on International Development. He received his $\mathrm{Ph} . \mathrm{D}$. in economics from Yale University. He is a coauthor of Cluster-based 
industrial development: an East Asian model (Palgrave Macmillan, 2006), Cluster-based industrial development: a comparative study of Asia and Africa (Palgrave Macmillan, 2011), and Cluster-based industrial development: kaizen management for MSE growth in developing countries (Palgrave Macmillan, 2014). $\mathrm{He}$ is a coeditor of Applying the kaizen in Africa: a new avenue for industrial development (Palgrave Macmillan, 2018). He is a recipient of the Nikkei Prize for Outstanding Book Publication and the Ohira Masayoshi Memorial Prize.

\section{Contributors}

Sugata Bose Department of History, Harvard University, Cambridge, MA, USA Takeshi Onimaru Kyushu University, Fukuoka, Japan

Takashi Shiraishi Prefectural University of Kumamoto, Kumamoto, Japan

Tetsushi Sonobe Graduate School of Policy Studies, National Graduate Institute for Policy Studies (GRIPS), Minato-Ku, Tokyo, Japan

Kaoru Sugihara Research Institute for Humanity and Nature, Kyoto, Japan

Keiichi Tsunekawa National Graduate Institute for Policy Studies, Tokyo, Japan

R. Bin Wong University of California, Los Angeles, USA 


\title{
Chapter 1 \\ Emerging States and Economies in Asia: A Historical and Comparative Perspective
}

\author{
Takashi Shiraishi
}

\begin{abstract}
Emerging nations are gaining weight in global economy and politics in the 21 st century. Proud of their achievement in recent years but confronted with the challenge of middle-income trap as well as specific risks and uncertainties that attend changes brought about by their rapid economic growth, they often question the postCold War global system of Pax Americana, liberal democracy, market economy, and self-regulating market and offer a new social contract of a life of plenty and security as the basis for a new global system. This chapter examines its significance in a long historical and comparative perspective and underscores the importance of states' ability to manage risks and uncertainties.
\end{abstract}

The notion of emerging nations - a shorthand for emerging states and economies-derives its meaning from such terms as emerging markets, emerging market economies, emerging powers, and emerging states, as well as the very idea of "emergence." But the notion is very much anchored in the idea of emerging economies and markets, the three fundamental characteristics of which are high economic growth, middle-income status, and higher risks and uncertainties institutional investors see those economies as facing compared to advanced industrialized economies. High economic growth over decades has put some of the emerging countries, most prominently BRICs (Brazil, Russia, India and China, a category originally invented by an investment bank), on a par in size with G7 advanced economies. The global share of developing and emerging economies also expanded from $20.2 \%$ in 2000 to $39.7 \%$ in 2015 , while the G7 share declined from $65.6 \%$ in 2000 to $46.3 \%$ in 2015.

Yet many emerging nations with middle-income status, confronted with the challenge of middle-income trap, tend to adopt approaches to global governance issues that differ from those of advanced industrialized nations. They also confront specific risks and uncertainties that attend the social, cultural, and political changes brought about by their rapid economic growth and their state capacity and behavior in manag-

T. Shiraishi $(\bowtie)$

Prefectural University of Kumamoto, Kumamoto, Japan

e-mail: takasisiraisi@gmail.com

T. Shiraishi and T. Sonobe (eds.), Emerging States and Economies, Emerging-Economy State and International Policy Studies, https://doi.org/10.1007/978-981-13-2634-9_1 
Table 1.1 GDP and GDP per capita in 2015, G20 countries, in current prices

\begin{tabular}{l|c|c}
\hline & GDP current prices (billion) & GDP per capita current prices \\
\hline USA & 18,037 & 56,175 \\
\hline China & 11,226 & 8167 \\
\hline Japan & 4382 & 34,513 \\
\hline Germany & 3365 & 41,197 \\
\hline UK & 2863 & 43,976 \\
\hline France & 2420 & 37,613 \\
\hline India & 2088 & 1616 \\
\hline Italy & 1826 & 30,032 \\
\hline Brazil & 1801 & 8810 \\
\hline Canada & 1552 & 43,350 \\
\hline S. Korea & 1383 & 27,105 \\
\hline Russia & 1366 & 9521 \\
\hline Australia & 1230 & 51,363 \\
\hline Mexico & 1151 & 9512 \\
\hline Turkey & 859 & 10,910 \\
\hline Indonesia & 861 & 3371 \\
\hline Saudi Arabia & 652 & 21,014 \\
\hline Argentina & 632 & 14,644 \\
\hline South Africa & 315 & 5721 \\
\hline & &
\end{tabular}

ing such issues as political instability and upheaval, social order, regulatory regimes, and macro-economic stability pertaining to currency, inflation, interest rates, and vulnerability to global economic changes, among others.

Emerging nations, thus defined, can still be identified differently, depending on which characteristics one focuses on. G20, the summit of which started to be held in 2008 in the midst of the global financial crisis, includes eleven emerging nations-Russia, China, India, Brazil, Mexico, South Africa, South Korea, Indonesia, Saudi Arabia, Turkey, and Argentina-together with G7 and Australia (and the European Union), because of their economic size (GDP) and hence their weight in the global economy (as shown in Table 1.1). Examining the steep decline of G7 shares in global manufacturing from 1990 to 2010, Richard Baldwin argues that the global manufacturing share of the Industrializing Six (I6) — China, Korea, India, Poland, Indonesia and Thailand-accounts for almost all of the G7's decline and that the manufacturing share of the rest of the world is hardly affected (Baldwin 2016: 3). Noting very high real income growth from 1988 to 2008, Branko Milanovic identifies emerging Asian economies, "predominantly China, but also India, Thailand, Vietnam, and Indonesia" as major beneficiaries of globalization and global expansion of middle classes (Milanovic 2016: 18-19).

Keiichi Tsunekawa in his chapter identifies 29 emerging states-defined as countries whose shares in the global economy have expanded substantially in the post- 
Cold War years of 1990-2014 and countries which are now seen as partners of advanced industrialized countries in global governance-and classifies them into three categories: eleven resource-rich countries (Iraq, Algeria, Nigeria, Venezuela, Saudi Arabia, Iran, Kazakhstan, Russia, Chile, Peru, and Egypt), whose exports overwhelmingly (60\% and above) depend on natural-resource exports and hence are vulnerable to fluctuations in global commodity markets; five countries with large domestic markets (China, Brazil, India, Korea and Mexico); and eleven others, many of which have succeeded in upgrading their technological capabilities and deepened their participation in global value chains, namely Singapore, Taiwan, Philippines, Indonesia, Malaysia, Thailand, Pakistan, Israel, Turkey, and Poland.

To put it in another way, the only world region in which examining emerging nations from a regional perspective makes sense is Asia (where natural-resourcerich countries aside, ten countries-China, India, Indonesia, Pakistan, Philippines, South Korea, Singapore, Taiwan, Thailand, and Vietnam-are located), while all the non-resource-rich emerging nations in other world regions with Poland as the only possible exception-Argentina, Brazil, Columbia and Mexico in Latin America, Israel and Turkey in the Middle East, and South Africa in Africa-are regionally isolated cases. This suggests that the trajectories of individual countries in Asia can better be understood by taking into account the larger regional system that shaped their internal and external dynamics as well as their interactions with each other and with other countries outside the region. The regional system of dense trade and production networks has developed in Asia, while it has hardly developed, for instance, in Latin America, even though Latin American countries liberalized their economies in the 1990s. This difference can be explained comparative-historically. In the colonial times, each part of Latin America was allowed to trade only with its metropole and not with each other. This pattern was enhanced further by the commodity boom in the late nineteenth and the early twentieth centuries when Latin American countries exported minerals and agricultural products to Europe and the U.S. The pattern was maintained in the succeeding years by the import substitution industrialization in which each Latin American country attempted to promote similar industries without any regional division of labor. Nor did Latin America benefit from "traditional" regional trading networks such as Indian and Chinese trading networks and, Mexico, a member of NAFTA aside, Japanese and NIEs investment for regional production networks. Hence the emphasis of this chapter on comparative historical and regional perspectives.

The scholarship on emerging states and economies tends to bifurcate either into cross-national inquiries, on the one hand, which address the questions of why and how some of the developing countries have emerged under a set of common global conditions, or into individual country studies, on the other hand, which address the question of what led them to choose the particular paths that resulted in their emergence. This book contributes to both types of scholarship and includes chapters on the historical trajectories of two major emerging nations-China and India- and a comparative analysis of colonial state-building of two city states (Hong Kong and Singapore) as well as chapters providing cross-national analysis of emerging states and economies and middle income trap. 
This introductory chapter focuses on emerging states and economies in Asia and looks at their pre-history, the political and economic issues, problems, and challenges they offer as well as confront, and the significance of their emergence in the region and the world. As such, this chapter, together with Kaoru Sugihara's chapter on intraregional trade, is meant to provide a comparative historical and regional framework and locate the trajectories of individual emerging countries in it to bridge the two approaches and to make better sense of emerging states and economies in Asia.

\subsection{Asia in the Long Nineteenth Century}

Angus Maddison has shown us what the advent of Europe, followed by the rise of the United States of America, meant for Asia. The share of Asia-and here Asia signifies India, China, Japan and the rest, including Southeast Asia-in the world economy was more than $50 \%$ in and up to 1820 . In the same year, China's population was 381 million, India's 209 million, Japan's 31 million, and Southeast Asia's 38 million, which combined accounted for $63 \%$ of the world population. China was the largest, both in terms of economic size and population, and had a 20-30\% share of the world economy and $23-37 \%$ of the world population under the Ming and Qing governments. India was the second largest, while the share of Britain, the front runner in the industrial revolution, in the world economy in 1820 was less than $5 \%$ (Maddison 2015).

After 1820, however, the Asian share of the world economy steadily declined, while the U.S. share, along with that of Western Europe as a whole, expanded rapidly, so that by 1950 , the Asian share had fallen below $20 \%$. In contrast, the share of the two world regions of North America and Western Europe combined surpassed 50\% in the mid-nineteenth century and remained so for more than a century.

By the turn of the 21st century, however, the Asian share in the global economy, in terms of purchasing power parity, has come back to almost $40 \%$, and it is now widely expected to surpass $50 \%$ and regain the position it occupied in the world economy two centuries ago (Maddison 2015). As Table 1.2 shows, the share of Asia (here denoting the Indo-Pacific region) in the global economy surpassed those of both North America and Europe (EU) in 2010 in terms of current prices.

The point here is not to argue that Asia, especially China and India, will be back as the two global centers of world economy and that a new Sino-centric tributary system will be in the making with the ascent of China in East Asia. For one thing, the last two centuries witnessed not only the ascendancy of Western Europe, but more importantly, the emergence of North America, especially the U.S., as the most dynamic and enduring center of the global economy. The rise of the U.S. has permanently changed the global distribution of wealth and population. The U.S. share in the global economy was miniscule in 1700 at $0.14 \%$ (when China's share was $22.29 \%$ ) and $1.8 \%$ in 1820 (when China's share was 32.9\%). But its share reached $27.3 \%$ in 1950 and has remained above $20 \%$ (both in purchasing parity and current prices) until now. This was and still is the most important development in the world history 
1 Emerging States and Economies in Asia: A Historical ...

Table 1.2 GDP and GDP shares of major regions and countries, current prices, in billion USD

\begin{tabular}{c|l|l|l|l|l}
\hline & 1990 & 2000 & 2010 & 2015 & 2020 \\
\hline World & 22,770 & 33,181 & 65,206 & 74,551 & 96,193 \\
\hline $\begin{array}{c}\text { Advanced } \\
\text { economies }\end{array}$ & $18,153(80 \%)$ & $26,486(80 \%)$ & $42,813(66 \%)$ & $44,940(60 \%)$ & $54,673(57 \%)$ \\
\hline G7 & $14,787(65 \%)$ & $21,778(66 \%)$ & $32,683(50 \%)$ & $34,530(46 \%)$ & $41,940(44 \%)$ \\
\hline $\begin{array}{l}\text { Emerging } \\
\text { economies }\end{array}$ & $4617(20 \%)$ & $6695(20 \%)$ & $22,393(34 \%)$ & $29,611(40 \%)$ & $41,520(43 \%)$ \\
\hline N. America & $6572(29 \%)$ & $11,024(33 \%)$ & $16,572(25 \%)$ & $19,541(26 \%)$ & $24,252(25 \%)$ \\
\hline USA & $5980(26 \%)$ & $10,285(31 \%)$ & $14,958(23 \%)$ & $17,968(24 \%)$ & $22,294(23 \%)$ \\
\hline Canada & $592(3 \%)$ & $739(2 \%)$ & $1614(2 \%)$ & $1573(2 \%)$ & $1958(2 \%)$ \\
\hline $\begin{array}{l}\text { EU (European } \\
\text { Union) }\end{array}$ & $7259(32 \%)$ & $8824(27 \%)$ & $16,966(26 \%)$ & $16,449(22 \%)$ & $20,188(21 \%)$ \\
\hline UK & $1093(5 \%)$ & $1549(5 \%)$ & $2407(4 \%)$ & $2865(4 \%)$ & $3852(4 \%)$ \\
\hline France & $1279(6 \%)$ & $1372(4 \%)$ & $2652(4 \%)$ & $2423(3 \%)$ & $2940(3 \%)$ \\
\hline Germany & $1593(7 \%)$ & $1956(6 \%)$ & $3423(5 \%)$ & $3371(5 \%)$ & $4005(4 \%)$ \\
\hline Italy & $1140(5 \%)$ & $1146(3 \%)$ & $2131(3 \%)$ & $1819(2 \%)$ & $2144(2 \%)$ \\
\hline Indo-Pacific & $5181(23 \%)$ & $8711(26 \%)$ & $18,735(29 \%)$ & $24,328(33 \%)$ & $33,966(35 \%)$ \\
\hline Japan & $3104(14 \%)$ & $4731(14 \%)$ & $5499(8 \%)$ & $4116(6 \%)$ & $4747(5 \%)$ \\
\hline China & $393(2 \%)$ & $1205(4 \%)$ & $6040(9 \%)$ & $11,385(15 \%)$ & $17,100(18 \%)$ \\
\hline S. Korea & $279(1 \%)$ & $561(2 \%)$ & $1094(2 \%)$ & $1393(2 \%)$ & $1899(2 \%)$ \\
\hline $\begin{array}{c}\text { Southeast } \\
\text { Asia }\end{array}$ & $373(2 \%)$ & $637(2 \%)$ & $1982(3 \%)$ & $2459(3 \%)$ & $3574(4 \%)$ \\
\hline Indonesia & $138(1 \%)$ & $179(1 \%)$ & $755(1 \%)$ & $873(1 \%)$ & $1194(1 \%)$ \\
\hline Malaysia & $47(0 \%)$ & $101(0 \%)$ & $255(0 \%)$ & $313(0 \%)$ & $544(1 \%)$ \\
\hline Philippines & $49(0 \%)$ & $81(0 \%)$ & $200(0 \%)$ & $299(0 \%)$ & $507(1 \%)$ \\
\hline Singapore & $39(0 \%)$ & $96(0 \%)$ & $236(0 \%)$ & $294(0 \%)$ & $395(0 \%)$ \\
\hline Thailand & $88(0 \%)$ & $126(0 \%)$ & $341(1 \%)$ & $374(1 \%)$ & $474(0 \%)$ \\
\hline Myanmar & $\mathrm{n} / \mathrm{a}$ & $10(0 \%)$ & $50(0 \%)$ & $66(0 \%)$ & $106(0 \%)$ \\
\hline Vietnam & $6(0 \%)$ & $31(0 \%)$ & $113(0 \%)$ & $199(0 \%)$ & $287(0 \%)$ \\
\hline South Asia & $419(2 \%)$ & $623(2 \%)$ & $2056(3 \%)$ & $2736(4 \%)$ & $3878(4 \%)$ \\
\hline India & $327(1 \%)$ & $477(1 \%)$ & $1706(3 \%)$ & $2183(3 \%)$ & $3444(4 \%)$ \\
\hline Oceania & $369(2 \%)$ & $451(1 \%)$ & $1389(2 \%)$ & $1412(2 \%)$ & $1711(2 \%)$ \\
\hline Australia & $323(1 \%)$ & $397(1 \%)$ & $1245(2 \%)$ & $1241(2 \%)$ & $1516(2 \%)$ \\
\hline
\end{tabular}


in modern times. For another, what we now call China, India, and other nations were very different entities, politically, economically, socially and culturally, in the nineteenth century. It is wrong to imagine China, India, and others as discretely defined national states floating in history and awaiting another glorious moment to appear on the center stage of global economy and world politics.

The regional distribution of wealth (and hence power) has undergone enormous changes over the last two centuries: Europe enjoyed its moment of glory in the long nineteenth century, from the post-Napoleonic wars to the Second World War; the U.S. emerged as the most dynamic center of global economy toward the end of the 19th century and has remained as such until now; and Asia, the region that encompasses the entire South, Southeast, and Northeast Asia, declined in the long 19th century and hit the bottom sometime in the early years after the W.W. II, but has since been regaining its share, although its ascent has come to be accepted as such only in the twenty-first century.

In light of these vicissitudes, the following questions can be raised: what are we to make out of the macro-level changes in the world economy over the last two centuries? What are the challenges ahead for Asia and the world, as China and India promise to be the two economic giants in an Asia that is now back in the center of the global economy? What challenges do emerging nations in Asia confront? What is the global and regional historical significance of emerging states and economies in Asia?

To address this set of questions, it is useful to recall what Karl Polanyi, a Hungarian political economist, had to say in his now classic book, The Great Transformation: the Political and Economic Origins of Our Time (2004), which he wrote in the U.S. during the Second World War. He began the book with the memorable sentence: "the nineteenth-century civilization has collapsed." And he continued:

\footnotetext{
Nineteenth century civilization rested on four institutions. The first was the balance-ofpower system, which for a century prevented the occurrence of any long and devastating war between the Great Powers. The second was the international gold standard, which symbolized a unique organization of world economy. The third was the self-regulating market, which produced an unheard-of material welfare. The fourth was the liberal state. Classified in one way, two of these institutions were economic, two political. Classified in another way, two of them were national, two international. Between them they determined the characteristic outlines of the history of our civilization. (Polanyi 2001)
}

Polanyi's notion of nineteenth century civilization was unabashedly Eurocentric, and the assumed singularity of this civilization meant that he literally viewed civilization as Civilization with a capital $\mathrm{C}$ and only in terms of the long nineteenth century of European ascendancy.

What is interesting about the Polanyi quotation is not its Eurocentrism, but its capacity to invite comparison. If we look back at European history, we may agree with Polanyi that the nineteenth century European system was indeed built on the four institutions of the balance-of-power system, the gold standard, the self-regulating market, and the liberal state. This system collapsed in the years between the 1910s and the 1940s, first with the breakdown of the balance-of-power system that led to the Great War in Europe (and we better remember that not much happened in Asia, 
except for economic booms, in those war years). The Great War was then followed by the collapse of Austrian-Hungary empire and the rise of nationalism as a legitimate political norm (as demonstrated in the establishment of The League of Nations), the rise of a communist state in Russia, the rise of Fascist Italy and Nazi Germany, the increasing erosion of liberal state legitimacy, the collapse of the gold standard, the Great Depression, the crisis in the self-regulating market, and the increasing state intervention in national economic management, culminating in the Second World War toward the end of the 1930s.

If we look at Asia in this long nineteenth century, an entirely different picture emerges. This was the long century in which Asia was colonized and subjugated. By the time the Napoleonic wars came to an end in Europe in the mid-1810s, the company-state called the British East India Company had transformed itself from one of several "country powers" in India into the "master of India". Administrative reorganization installed a "despotism of law" by creating the Indian Civil Service as the "steel frame" of Indian administration, and making the Company army, expanded to 155,000-strong during the Napoleonic wars, one of the largest European-style standing armies in the world (Metcalf and Metcalf 2012: 60-68).

The long nineteenth century of colonization and subjugation arrived in Southeast and Northeast Asia later. Hamashita (1997) argues that Maritime Asia was a series of seas extending from Southeast Asia to Northeast Asia, encompassing countries and regions, trading centers and sub-centers, located along the periphery of the Eurasian continent. Maritime Asia was not the same as non-Chinese Asia. The Kombaung dynastic state in upper Burma and Mataram in central Java were as inland, inwardlooking, and agrarian-based as Qing China, while the coastal regions of Southern China in the late Qing and the Republican era were as maritime, outward-looking, and trade-based as Manila and Bangkok had been in the same years. Historically China managed its trade with maritime zones through the tributary system (which was complemented by the Hushi [trade] system under the Qing) (Ueda 2005; Hamashita 1997). It did so, not because it wanted to translate its attraction as a market into political and cultural hegemony, but rather to prevent private trade from undermining the imperial order.

The British, who had colonized the Indian subcontinent by the early nineteenth century, expanded their informal empire into East and Southeast Asia in the course of the nineteenth century. The Dutch Verenigde Oost-indische Compagnie (VOC) and the Spanish Philippines, whose presence in the region predated the regimes in Tokugawa Japan and Qing China, had established colonial control over Java and the Moluccas (as well as a few strategically located outposts on Sumatra, Sulawesi and Kalimantan) and the northern and central parts of the Philippines by the end of the eighteenth century. Losing out in the Napoleonic wars (and, in the case of Spain, losing its huge colonial empire in the Americas), however, they were unable to compete with the British to establish hegemony in the seas in the first half of the nineteenth century. Britain projected its naval power into the Asian seas stretching from the Indian Ocean to the Malacca straits to South and East China Sea. The establishment of Singapore in 1819 (along with Penang in 1784 and Dutch-ceded control of Malacca in 1824) and Hong Kong in 1842 in the wake of British victory 
over Qing China in the Opium Wars of the 1840s were the most enduring historical legacies of British formal and informal empire-building.

British empire-building created the framework for collective imperialism in Asia. Its commercial origins meant that empire-building was structured to "maximize profits" (Kupchan 2014), with its colonies providing markets and raw materials for the metropole. The empire was built on naval supremacy and a network of linkages among strategic outposts. It kept its army small, while mobilizing its Indian army for the task of far-flung empire-building as well as for major wars. It deliberately avoided strategic commitments on the European continent, and as a logical extension of its policy to maintain a stable balance of power in Europe, it also accepted stable balances of power in major overseas theaters. Under its aegis, a framework for collective imperialism in Southeast Asia and China was constructed. The British also concluded an alliance with Meiji Japan in the early twentieth century to maintain balance against the French and the Russians in the Far East.

In this framework of collective imperialism, Southeast Asia, with Siam as a partial exception, was carved up by European powers into their respective colonies toward the end of the nineteenth century-Burma, Malaya, and northern areas of Borneo under the British, the Indies from Sumatra to the western half of New Guinea under the Dutch, Indochina under the French, and the Philippines, first under the Spanish and then under the Americans, with Goa, East Timor and Macao as the small outpost remains of the once powerful Portuguese seaborne empire in Asia.

Technological and organizational capacity accounted for the military superiority of European powers over local forces. Modern colonial states were fashioned for internal pacification and resource extraction. The colonial Leviathan was a machine, an apparatus, manned predominantly by natives under the command of white European officials and imposed on the colonies to control their lands and peoples. ${ }^{1} \mathrm{U} \mathrm{Nu}$, the first prime minister of independent Burma, famously compared it to a dilapidated car $(\mathrm{Nu} 1975)$.

Colonial economies were organized with plantations and mines as their mainstays. Sugar was produced in Java, Central Luzon and the Visayas, and Negros, tobacco in northern Luzon, tin in Malaya, rubber in Malaya, Sumatra and southern Vietnam, and rice in Burma, south Vietnam, and Thailand. Labor was imported from India and southern China, large-scale immigration that had lasting impact on the demographic structures of areas like Malaya as Sugata Bose writes in his chapter. Opium, imported from British India, provided a strategic means for colonial states to exploit Chinese coolie labor in British Malaya and Javanese peasants in Dutch Java for funding colonial state-building (Rush 1990; Trocki 1999).

The colonial drain, combined with the handicap in developing human capital and the lack of macro-economic policy autonomy, resulted in diminishing welfare. Income transfer from the Dutch Indies to the Netherlands amounted to more than ten percent of Dutch NDP (Net Domestic Product at factor cost) in 1921-1939, while colonial drain from India to Britain in the same years was about $1.5 \%$ of Indian NDP

\footnotetext{
${ }^{1}$ (Shiraishi 2000). Almost $90 \%$ of the colonial civil service, about a quarter of a million, were native in the Dutch Indies state in 1928, for instance (Anderson 1991: 98-99).
} 
(Maddison 1990; see also van Zanden and Daan 2012). Yet, in striking contrast to the countries in Africa, the Middle East, and Latin America, which were increasingly integrated into the metropole-led international economy as satellites, intra-Asian regional trade expanded faster than the trade between Asia and Europe from 1880 to 1938 , as Kaoru Sugihara argues in his chapter, owing to the expansion of Indian, Chinese and other Asian merchant networks.

A major institution of the collective imperialism in mainland China was the treaty port system, built on the unequal treaties Qing China concluded with Western powers that conferred extraterritoriality on Western powers and deprived Qing China of its tariff autonomy. The most-favored-nation clause in the treaties the Western powers concluded with Qing China underwrote the collective nature of empire. The treaty port system took shape with the opening of Hong Kong, Amoy and Shanghai, followed by the opening of more ports along the Yangtze River and the Yellow Sea coast in the mid-nineteenth century and the construction of railways in China's interior toward the end of the nineteenth century and the early twentieth century. ${ }^{2}$

This "western impact" undoubtedly threatened Qing China's territorial integrity and imperial confidence, but it was a series of regional rebellions culminating in the Taiping rebellion in the 1850 s and 1860 s that devastated its economy and society and triggered the shift in power from the center to the provinces where senior Han officials organized defense against rebellions, worked on the promotion of industries, and restored social order with the support of the local gentry.

It is also important to note that colonial and semi-colonial Asian countries were at peace with each other. European powers mostly fought brutal "little wars", coopting as well as killing and subjugating natives. But in the eighty-year period following the Napoleonic Wars, these colonial powers never fought with each other in the region until the Spanish-American war in 1898, in which the Americans defeated the Spanish naval forces in the Philippines as a part of the larger war centered on Cuba. The British-led collective "white peace," accompanied by internal colonial repression and subjugation in Southeast Asia, was a byproduct of the European balance-of-power system. This white peace under British naval hegemony would be broken by the U.S. to mark its arrival in Asia.

Two major countries escaped the fate of colonization. Siam lost its tariff autonomy and granted extraterritoriality to Western powers in the unequal treaties it concluded, starting with the Bowring treaty in 1851. Its traditional enemies-Burmese and Vietnamese-having been pacified by the European colonizers, Siam no longer worried about external threats as long as it could carefully maintain its (asymmetrical) relations with the British and the French. In the following years, especially under King Chulalongkorn, whose reign (r. 1853-19190) coincided with that of the Meiji Emperor (r. 1852-1912), the dynastic state in Siam went about its own internal pacification and undertook modern state building, modeling itself after the neighboring colonial states of British Malaya, Dutch Indies, and British India (Anderson 2014). Around the same time, Japan under the Meiji government embarked on its own civilizing project-here "civilization" meant European as per Polanyi's nine-

\footnotetext{
${ }^{2}$ For a different take of this process from the Qing state perspective, see (Okamoto 2016).
} 
teenth century Civilization (Fukuzawa 2013) — of building a nation-state from above along the lines of "Rich Nation and Strong Army" (modeled after the British, French and German imperial powers) and emerged as a regional power by the first decade of the twentieth century with its victory over Qing China in 1894-1895 and Russia in 1904-1905. In other words, the long nineteenth century that saw the rise of the British as the hegemonic power and Japan's victory over Qing China the 1890s sealed the fate of the Sino-centric tributary system.

In sum, what Polanyi calls the nineteenth-century civilization manifested itself in the colonization and semi-colonization of Asia, with the partial exceptions of Siam/Thailand and Japan, and the collective imperialism as a regional foundation of white peace, replacing the Sino-centric tributary system. It was built on a huge gap between Western powers and Asians in terms of technological and organizational capabilities and industrial prowess, buttressed by the myth of white supremacy. The emergence of Japan as a power was marked, characteristically, by the elevation of Japanese to the status of honorary whites, creating an anomaly, in the eyes of natives, of Japanese prostitutes in the Dutch Indies enjoying the status of Europeans while Chinese tycoons remained foreign Orientals.

The demise of the British-led collective imperialism in Asia also differed from the collapse of the nineteenth-century civilization in Europe. By the time President Woodrow Wilson made his national self-determination speech in 1918, revolution had broken out in Russia and led to the establishment of the Soviet Union. In the wake of the dismemberment of Austria-Hungary empire, nationalism was enshrined as a legitimate political norm by the League of Nations, and although Asians-and non-whites in general-were deemed (by their colonizers) not "ready" for national autonomy, nationalism was all the same on the rise in many places in Asia. Revolution broke out in the Spanish Philippines in 1896, and briefly led to the establishment of the first republic in Asia, even though it was soon destroyed by U.S. occupation. Sun Yat-sen, with his base in Hong Kong and Yokohama and other port cities, mobilized manpower and money for his revolutionary cause from among Chinese in the coastal regions of Southern China and Southeast Asia. By the mid-1920s the rise of Chinese nationalism threatened the informal imperialism in China and triggered an increasingly serious systemic crisis. The Dutch Indies witnessed the emergence of Sarekat Islam in the 1910s, the left wing of which turned to communism and organized an uprising in the mid-1920s. And in Indochina, the nationalist mantle was handed over from the Vietnamese literati of Phan Boi Chau's generation to French educated intellectuals of Ho Chi Minh's generation in the 1920s.

It was in this context of the deepening crisis of the nineteenth-century civilization in Europe and the rise of nationalism (and communism) in Asia that Japan belatedly embarked on its own empire-building. Japan colonized Taiwan in the wake of its 1895 victory over Qing China and Korea in 1911 after its victory over Russia, made the Twenty-One Demands on Republican China in 1915 to inherit German interests there, invaded Manchuria and established Manchukuo in the early 1930s, engaged in all-out invasion of and war against China in 1937, and finally went to war with the U.S. and Britain in the 1941. Historians tell us that the two events-the assassination of Zhang Zuolin in 1927 and the occupation of Manchuria in 1931, both engineered by 
officers of the Kwantung Army - that marked the Japan's "Asianist" turn in its empire building were themselves defensive moves against rising Chinese nationalism which threatened Japan's largely informal empire in Manchuria (Kitaoka 1999). This was a fatal grand-strategic mistake that caused enormous suffering, brutality, and countless lives lost.

Japan's belated empire-building not only destroyed the system of collective imperialism and took on the United Kingdom, the United States, and other powers as enemies, but also made nationalism in Asia, especially China, its enemy. Japan declared war on the United States and the United Kingdom in 1941. Japanese victories and occupation of Southeast Asia in the early days of the war destroyed the myth of white supremacy. In areas that came under Japanese occupation, colonial economies collapsed. Japanese army authorities imposed harsh levies in labor and kind and printed money, leading to hyperinflation and widespread corruption. Japanese brutality and exploitation aroused deep popular hatred among the colonized (Anderson 1966). The Greater East Asian War was the war that destroyed the nineteenth-century civilization in Asia.

Japan lost the war. A devastated China and Southeast Asia experienced deep and extensive social, economic, and political crises, while India went independent, although Pakistan went its own way in the wake of the bloody partition. Deep systemic crisis triggered revolutions and counter-revolutions, the repercussions of which would be felt well into the 1960 s, the so-called "age of decolonization."

\subsection{Asia Under the US Hegemony}

In the wake of World War II, a bipolar world emerged. Europe was divided into U.S.led Free Europe and the Soviet empire. The U.S.-led Free Europe, which would evolve into the twentieth century system, was built on the debris of the nineteenth century civilization. It was built on the three main institutional foundations. Pax Americana replaced the balance of power system. The liberal state was expanded into the liberal democratic state. Pax Americana and the liberal democratic state were to provide the political foundation for the new system. Embedded liberalism, informed by Keynesian economics, combined free trade with the freedom of national governments to provide welfare and to intervene in their economies to maintain full employment. It was institutionalized in the Bretton Woods system with the establishment of the International Monetary Fund (IMF) and the World Bank. It aimed not only at an open system of international trade in goods and services based on a semifixed dollar gold exchange rate system, but also at embedding market forces into a system in which those market forces would be regulated by national governments with their control over capital accounts (Helleiner 1994).

The U.S.-led twentieth-century system has undergone significant changes over the course of Cold War years and after. The dollar gold standard gave way to the dollarled floating exchange rate system in the 1970s. Capital movement across national boundaries became the norm by the early 1990s (Helleiner 1994). Regional Free 
Trade Agreements have gained momentum since the 1980s, while the GATT trading system has evolved into the WTO (World Trade Organization) system by the end of the 20th century. Capital account liberalization and free trade led the transformation of embedded liberalism into a de facto "self-regulating market without the gold standard." 3 This development, combined with the revolutionary advancement in information and communication technology, unleashed economic globalization or "the second unbundling" and led to "great convergence" and the rise of emerging states and economies (Baldwin 2016).

Democracy promotion also gained traction in the 1980s, with the "People Power" revolution in the Philippines in 1986, the democratization of South Korea in 1987, and the democratic revolutions in East European states in 1989. With the collapse of the Soviet Union the Cold War came to an end. As the sole remaining "superpower" with enormous military capability and technological prowess (as demonstrated in the Gulf War in 1991), American grand strategic thinking shifted from containment, which no longer made any sense, to globalism that promoted globalization in the name of free trade, financial globalization, democratization and good governance (Brzezinski 2008).

Different from the British hegemony, which was commercial and extractive in origin, U.S. hegemony was (and still is) founded on "geopolitical imperatives and ideological ambition" (Kupchan 2014). The U.S. constructed different architectures in different strategic theaters, relying on different geopolitical logics. This is clear from the way in which the U.S. went about fashioning a regional order in Western Europe and East Asia.

The strategic challenges the US faced in Western Europe in the immediate postwar years were: first, how to counter the communist threat and contain the Soviet Union, and second, how to rebuild West Germany economically and make it an American ally, while making sure that it would never again be a threat to the United States and its allies. The answers it found to these questions are well-known: In security this resulted in the creation of the American-led North Atlantic Treaty Organization (NATO) as a collective security institution, and in economic terms, the formation of a European common market built on the partnership between France and West Germany, which has evolved into the European Union (Katzenstein and Shiraishi 1997; Katzenstein 2005).

A similar set of questions was posed in Asia. The first was how to contain the threat of international communism emanating from Soviet Russia and communist China-and here, we should recall that China went communist in 1949 and war broke out in the Korean peninsula in 1950. The other question was how to revive Japan as a workshop and a base for American forward defense, but make sure at the same time that Japan would never again be a threat to the US. The answers the U.S. came up with are, again, well-known. One was double containment. Containing the Soviet Union and communist China on the one hand, while containing Japan on the other or, to use George Kennan's graphic metaphor, keeping America's light hold on Japan's jugular, which was done first by integrating Japan's military power into the

${ }^{3}$ I owe this point to Dr. Osamu Saito. 
regional security system created and led by the U.S. and second by American control over Japan's energy supply (Cumings 1997).

The other was the fashioning of the U.S., Japan and Southeast Asian triangular trade system. Before the war, Japan's two most important trading partners were the U.S. and China, and Japanese business hoped to trade with China, as well as with the U.S., after the war. In the early years of the Cold War, however, China had to be contained, and the U.S. could not afford to allow Japanese business to trade with China and undermine its containment policy against China. Instead, the U.S. encouraged Japanese to go south and normalize diplomatic relations with Southeast Asian countries in "Free Asia".

The American-led Free Asia was thus organized differently from American-led Free Europe. The PRC victory in China and the Korean war powerfully impacted the American design of Asian regional order. Applied to maritime Asia, U.S. policy was geared toward the containment of communism, and by the mid-1950s the demarcation line had been drawn at the border separating North from South Korea, Taiwan and Hong Kong from mainland China, and North from South Vietnam. War, however, continued in Vietnam and expanded to its neighbors, culminating in the unification of Vietnam in 1975 and Pol Pot's coming to power in Cambodia, only to be followed by the genocide and another war in Cambodia throughout the Cold War era. Outside the war zone of Indochina, Free Asia was anchored institutionally on a string of bases from which the U.S. projected its military power to contain communist Asia and maintain its hegemony in the region. China joined in Free Asia in the 1980s after Sino-US and Sino-Japanese rapprochement in the early 1970s and Deng Xiaoping's decision on reform and opening in 1978. In contrast to the British informal empire, whose interests were primarily defined in commercial terms, the outer limits of American hegemony were as military. Within these limits, the U.S. encouraged its allies, strategic partners and client states to develop their economies, while providing its huge market and its enormous financial and technological resources. Japan also joined in the U.S.-led development project. As long as they were anti-communist, it did not matter whether the US allies and clients were liberal democratic, illiberal democratic, authoritarian, or autocratic. And in the 1970s and 1980s after the rapprochement, the US also enlisted communist China as its strategic partner in its cold war against the Soviet Union and President Reagan famously called the People's Republic of China "so-called Communist China," implying it is not really communist (Mann 1999). The name of the game was stability and order.

Free Asia was thus built, not exactly on the same institutional principles as in Free Europe. Pax Americana and the international framework for embedded liberalism - the Bretton Woods system and the GATT trading system — and its successor, the self-regulating market without the gold standard were there. But most states except Japan remained undemocratic and often quite repressive of their own people until very late in the Cold War and post-Cold War years. Many of the states also free-rode on the international economic system, actively managed their national economies and went about development from above, with their currency pegged to the US dollar and with their internal security and technocracy run by American-trained military officers and technocrats as two most important state institutions. 
Johnson (1982) in his attempt to account for the postwar Japanese economic miracle came up with the concept of "developmental state" as a "model and case" of successful late industrialization, "the best example of state-guided market system" involving close collaboration between the state and big business and the private sector more generally in pursuit of developmental goals. Although his equation of the developmental state with the combination of authoritarianism and developmentalism is unconvincing (and his attempt to call democratic Japan soft authoritarian is dubious), it provided an influential model for understanding the political economies of Asian NICs (South Korea, Taiwan, Hong Kong and Singapore), ASEAN 4 (Indonesia, Malaysia, the Philippines and Thailand) and finally China. ${ }^{4}$ Their arrival was marked with the establishment of a super agency of economic policy making, U.S.led international developmental support, and the change in general orientation of developmental policy from import substitution industrialization (ISI) to a mix of the ISI and export-oriented industrialization (EOI) (Takagi et al. 2018; see also Suehiro 1998).

In effecting a marriage between economic nationalism and neo-mercantilism, the developmental state represented the East Asian response to a world dominated by the West, a response that eschewed the option of socialist revolution by opting for a statebuilding and economic development from above, based on the politics of productivity. Focused on national economic development, the politics of productivity sought to contain class, ideological, and other divisions by delivering prosperity to the majority through rapid economic development, without recourse to regime change by violent revolution (Maier 1978). This politics would become a mainstay of the region, one that still exerts a powerful attraction for states like China. In aiming to catch up with developed nations, the developmental state manages its economic system on the basis of private property rights and a market mechanism, but sets industrialization as their main objective and intervention in the market as legitimate insofar as such intervention is able to achieve the main objective (Hau 2016).

The fact that the U.S. made different strategic choices in East Asia and Western Europe had a profound impact on the structure of the two regional systems. In Western Europe, the French and Germans embarked on a joint project that was deeply informed by a Europeanist ideology. The Europeanism underpinned the political will to build a peaceful and prosperous Europe and led to the formation of a community anchored in the larger North Atlantic collective security system. In other words, regionalism has been the driving force in the making of Western Europe.

In East Asia, by contrast, there was neither the political will to create a community nor a sense of identity as Asians to serve as the basis for "Asianism" as a regionalist ideology. Nationalism informed the purpose of national states. And the national political will to develop found its expression in developmentalism as part of the nation building project from above. East Asia has emerged as a region through a process of economic integration with the world economy driven by the tremendous regional economic development, powered by foreign direct investment, especially in

\footnotetext{
${ }^{4}$ But see Johnson (1987) for his argument about how and why communist China is different from developmental states.
} 
the wake of the Plaza Accord in 1985, from Japanese as well as American, European, South Korean, Taiwanese and overseas Chinese businesses. In other words, it was market forces, and not the collective political will informed by Asianism, that led to the regionalization of East Asia in the 1980s and 1990s. The regional structure fashioned by the U.S. in the early Cold War years provided the framework for this development. The regional security system remains an American-led hub-and-spokes system. At the same time, however, the regional trade system has evolved out of the original triangular trade system with the integration of China and other countries into the system since the 1980s.

Given the different regional architectures fashioned in the postwar years, it is not surprising that the Cold War also came to an end differently in Asia and Europe. Democratic revolutions in East European countries, the unification of Germany, the collapse of the Soviet Union, the bloody civil war in the former Yugoslavia, the NATO eastward expansion and the deepening and expansion of European integration-all these developments meant significant geopolitical changes in Europe. Nothing of this sort took place in Asia except the arrival of peace in Indo-China in the early 1990s and the joining of Indochinese nations and Burma/Myanmar in the ASEAN. Democratic transformations did take place in the 1980s and 1990s, not in socialist countries but rather in America's client and partner states such as the Philippines, South Korea, Taiwan and Indonesia. Although there were democracy movements in China and Burma/Myanmar, no socialist state in East Asia collapsed. Instead, China and Vietnam, opting for their own version of developmentalism, transformed themselves from socialist party-states into socialist market economy party-states. Myanmar chose for a different path of political liberalization, even though its future prospects look shaky, while North Korea remains Kim's brutally repressive and economically stagnant dynastic party-state (Shiraishi and Hau 2010).

The post-Cold War years also witnessed the 1997-1998 East Asian economic crisis and the demise of authoritarian developmental states. Buoyed by the inflows of FDIs and other capital in the wake of the Plaza Accord in 1985, some of the East Asian economies enjoyed enormous boom with the Thai economy, for instance, growing at $9.5 \%$ and Malaysian economy at $9.1 \%$ annually from 1987 to 1996 . With their currencies pegged to the U.S. dollar and their expectations for profit inflated in the bubble, their firms borrowed money in dollars without hedging currency risk for both productive and unproductive purposes. But the trend in the yen-dollar exchange rate movement reversed in 1995 and their currencies, pegged to the appreciating dollar, undermined their competitiveness in the international markets. This led to the liquidity crisis in Thailand in 1997, which then spread to South Korea, Indonesia and Malaysia. The U.S. seized the opportunity to impose structural reform as part of IMF conditionality for liquidity support. The South Korean developmentalist regime was dismantled. The crisis led to the constitutional revision and rise of Thaksin Shinawatra in Thailand, while triggeringthe collapse of Suharto's New Order regime in Indonesia and the near collapse of Mahathir Mohamad's National Front regime in Malaysia (Shiraishi 2005).

By the end of the 1990s, however, the premise of the developmental state, which stressed state-led late industrialization founded on export promotion and industrial 
upgrading, had been undermined anyway by the new reality of capital account liberalization, trade liberalization, evolving global value chains, and the increasing importance of services across economic sectors including those embedded in manufacturing and agriculture. ${ }^{5}$ Nothing shows this change better than the fact that India and the Philippines, once seen as two basket cases of flawed democracy and economic stagnation, have posted economic growth on a part with, if not better than, the last two remaining developmental states of socialist market economy type, China and Vietnam.

And finally, the post-Cold War years witnessed the rise of China. China's socialist economy has undergone enormous changes since the 1970s when the party leadership decided to shift gears from self-reliance to integrating China to the global economy and in so doing transforming its socialist economic system. In the 1980s China dismantled the communes and other collective institutions, welcomed substantial foreign direct investment, aid and loans, promoted domestic markets, and embarked on a national development strategy. There was a major setback in 1989-1990, in the wake of the Tiananmen massacre, which destroyed whatever legitimacy the communist ideology had provided with China's party state, forced it to embark all-out on its own politics of productivity and its own version of state capitalism to buttress its legitimacy. China's high economic growth in the 1990s and beyond proved its strategy right. The Chinese economy, export and import grew on average at 10, 15, and $16 \%$ respectively in ten years from 1991 to 2000 . Its trade dependence increased from $29.6 \%$ in 1990 to $39.6 \%$ in 2000 . In so doing, China has become deeply integrated into the postwar triangular trade system, while at the same time remaining outside the American-led hub-and-spokes regional security system (Shiraishi 2012).

That China successfully transformed itself from socialism to socialist market economy turned out to be crucial for the survival of other socialist states on its vicinity. Both the dynastic party state in North Korea and the military junta in Burma/Myanmar survived while becoming increasingly dependent on China. Vietnam followed China's footsteps in transforming itself from socialism to socialist market economy. The region, once bifurcated in the 1950s to the 1970s, became increasingly integrated economically, preparing the ground for institution-building in the post-Asian crisis years, with divergent political systems.

The rising China has also proven U.S. China policy wrong. American policy makers, both Democrats and Republicans, assumed that integrating China into the U.S.-led economic order would make China “like us." Sandy Berger (1997), President Bill Clinton's national security advisor pronounced that "the emergence of China as a great power that is stable, open and nonaggressive; that embraces political pluralism and international rules of conduct; that works with us to build a secure international order-the emergence of that kind of China profoundly is in America's interest." This assumption underpinned the U.S.-China grand bargain: China would be a junior partner of the U.S., working together to maintain the regional order that would provide China with a benign international environment for its export-led economic growth. The bargain, couched in the language of China's "hide and bide" (Deng Xiaoping)

\footnotetext{
${ }^{5}$ For the increasing importance of services embedded in manufacturing, see Baldwin et al. (2015).
} 
and American expectations that China would be a "responsible stakeholder," led to the creation of what Peter Temin and David Vines call Bretton Woods II (Mastanduno 2014; Temin and Vines 2014).

The Bretton Woods II arrangement worked for a decade. China enjoyed an accommodating global economic environment for its exports and posted high economic growth. Its trade surplus was recycled to finance U.S. current account deficits and keep U.S. interest rates low, allowing the U.S. to cut taxes, increase defense spending, fight the war on terror in Afghanistan, Iraq and elsewhere, and sustain economic growth (Mastanduno 2014).

Integrated into the regional economic system, China has in turn transformed the regional system by greatly expanding the intra-regional and global trade and in doing so, effectively decentering the U.S. Hence, we are witness to the current anomaly in which the U.S. has been increasingly decentered economically while remaining the hub of the regional security system, from which China is excluded. This structural anomaly has become pronounced in recently years since President Xi Jinping stopped talking about China's "hide (its power) and bide (time)" and in effect started challenging the U.S.-led regional order both in security and economic cooperation. The U.S. under President Obama called for pivoting, in effect giving up hope that China would be "like us" someday, a point now frankly admitted in the 2017 National Security Strategy President Trump signed. This explains why many states in the region engage in a delicate balancing act, aligning with the U.S. and its allies for security on the one hand, while engaging China for economic cooperation.

The kind of regional structure that now informs these two different but simultaneous types of politics - in short, power balancing and economic cooperation-is likely to remain in place for quite some time, while the structural tension between the U.S.-led regional security system and China's increasing clout in the trade and investment system will mount. This means that despite the promise of globalization, the twentieth century system-with Pax Americana, the liberal democratic state, and the self-regulating market without the gold standard as its defining institutional features-has not quite evolved into the twenty-first-century global system.

The zone of failed states has also been expanding from Central Asia to the Middle East, Maghreb and Sahel to East and West Africa, where radical Islamist challenges pose a fundamental opposition to the very assumptions of nation-states and globalization. A de facto Eurasian continental alliance, with China and Russia as senior and junior partners, may be in the making. In Asia, which survived its systemic crisis in 1989-1990, there are no signs that China, which has benefited greatly from the U.S.-led twentieth century system, is accepting all its institutional norms. China remains a party state and at least one-third of its market economy is under state control. Instead, China under Xi Jinping with his China Dream of restoring the country's 3000-year glory looks intent on making itself the regional hegemon, calling for "rich nation, strong military" (reminiscent of Meiji Japan's "Rich Nation, Strong Army") and "Asian security by Asians" (reminiscent of the Japanese empire's Asianist turn in the late 1920s and early 1930s), while promoting economic cooperation with its neighbors and building its sphere of influence in the name of OBOR (One Belt One Road) (Shiraishi 2016). 


\subsection{Challenges Ahead}

The world of the twenty-first century will not be the global expansion of the twentiethcentury Free World system. In the future, people may see the rise of Donald Trump as U.S. president and his call for America First as signaling the moment when the Americans lost their national political will to sustain the U.S.-led global system. ${ }^{6}$ But it is also important to remember that the U.S.-China grand bargain has been undermined since the 2008 global financial crisis and that the days when China could free-ride on a benign international system for its economic growth are coming to an end. China's share in the global economy, measured in current prices, expanded from less than $4 \%$ in 2000 to more than $15 \%$ in 2015 and is expected to surpass $20 \%$ in the early 2020s. A China this big cannot hope to free-ride on the global system for its economic growth, while maintaining its domestic political and economic system intact as a party state-led socialist market economy, making huge investment in technological development, insisting on technology transfer by MNCs, modernizing and expanding its military, asserting its sovereign rights on the basis of its imagined traditional suzerainty, building artificial islands on disputed waters in South China Sea, expanding its sphere of influence on its vicinities, and constructing a continental coalition vis-à-vis the U.S.-led alliance system in Asia.

There will be more uncertainties, if not mounting tensions, as China rises and becomes more assertive. Balance-of-power politics will be more pronounced in the coming years in Asia. Uncertainties will be compounded further by the "America First" President Trump. The U.S. fears China's technological ascendancy and is tightening its industrial security. U.S. third offset is targeted at China. Trade war may escalate anytime. Now that the US and its allies have given up hope that China will be a market economy and a democracy - even as China is building its state-of-the art surveillance state-there will come a time in the near future when its leadership has to make a set of major grand strategic choices about the position it wants to have in the region and the world. ${ }^{7}$

It is important to remember, however, that it is not just China which is rising. Asia has emerged as the region of emerging states and economies, all, including China, connected with each other as well as with advanced industrial economies by transnational value chains. The Indo-Pacific - a shorthand for the entire region of Northeast, Southeast, and South Asia plus Oceania-surpassed both North America and the European Union in economic size by 2010. China surpassed Japan in economic size in 2010. And sometime in the 2020s India as well as the ten Southeast Asian economies combined will also surpass Japan in terms of GDP. Although Southeast Asian states' military spending is miniscule for now-in 2016 Singapore had the largest defense budget which was less than 5\% of China's-India's military spending has surpassed Japan's for quite some time, while Australian military spending rose to more than two thirds of Japan's in recent years. This development

\footnotetext{
${ }^{6}$ For a different take on America First, see Bacevich (2016).

${ }^{7}$ My own take on the rise of China and its hegemonic implications, see Shiraishi $(2014,2016)$. See also Ikenberry (2014) for a more theoretically oriented examination of the question.
} 
explains why the Indo-Pacific regional framework makes sense from the U.S. and Japanese perspectives to promote security cooperation with Australia and India and why Southeast Asia, especially its maritime part, occupies such a strategic position for the future of this region.

Another challenge, which may create even more uncertainties in Asia in the coming years, is how to meet the expectations people have come to entertain in this region due to the phenomenal improvement in their standard of living over a generation. With Brexit and the election of Donald Trump as U.S. President in 2016, the rise of populism, nationalism, anti-globalism, anti-liberalism, racism and the "retreat of democracy" are much talked about. One way to understand this anti-globalist antiliberalist turn is to look at who did well in the current globalization and who did not (Milanovic 2016). Another way to understand it is to look at whether and how much people's expectations for better life are met. As Table 1.3 shows, the U.S., Canada, and West European countries did very well in the first ten-year period from 1996 to 2005, but dismally in the ensuing ten-year period from 2006 to 2015. In the first ten-year period from 1996 to 2005, countries such as the U.S., Britain, the Netherlands, Spain, France, Germany, and Italy experienced their GDP per capita expanding from 100 to 111-128. Japan's per capita GDP in the same period grew from 100 to 106, the most dismal performance among all the OECD countries. This is the reason Americans and West Europeans talked about the "Japan Disease", holding Japan up as an example of unsound economic management and a cautionary tale of what not to do when running the economy.

In the following ten-year period from 2006 to 2015, however, the picture changed radically. Germany was able to maintain its steady performance with its GDP per capita rising from 100 to 111 , in part because the Euro zone of currency stability allowed the German economy to exploit its competitive advantage vis-à-vis other European economies. But Germany was the exception. In such countries as the U.S., Canada, Britain, the Netherlands and France, their per capita GDPs only expanded on average from 100 to 101-104, while countries such as Italy and Spain saw their per capita GDPs shrink. For that matter, Japan's performance remained stagnant with its per capita GDP expanding from 100 to 104, on a par with the U.S. and Canada and better than Britain, the Netherlands, and France. We have thus seen the Japanization of North American and West European economies and the "Japan Disease" is no longer confined to Japan.

This difference in performance goes a long way toward explaining the difference in politics in the US and Western Europe on the one hand and Japan on the other. Precisely because the U.S. and Western European countries experienced an economic boom in the immediate post-Cold War years from the 1990s to the mid-2000s, their peoples had come to entertain higher expectations for bettering their living standards. When their expectations were not met, they became unhappy, sometimes angry, at their governments and "elite". Hence the rise of anti-globalism, inward looking nationalism, racism, etc. Nothing of this sort happened in Japan, because Japanese have come to accept stagnation in their living standards as "normal" and because they witnessed populist movements' self-destruction in the rise and fall of DPJ-led government in 2009-2012. 
Table 1.3 Revolution of rising expectations

\begin{tabular}{|c|c|c|c|c|c|c|}
\hline & \multicolumn{4}{|c|}{$\begin{array}{l}\text { GDP per capita, constant prices (national } \\
\text { currencies) }\end{array}$} & \multicolumn{2}{|c|}{$\begin{array}{l}\text { GDP per capita growth } \\
(\%)\end{array}$} \\
\hline & 1996 & 2005 & 2006 & 2015 & 1996-2005 & 2006-2015 \\
\hline China & 8916 & 18,251 & 20,460 & 43,074 & 205 & 211 \\
\hline S. Korea & $14,852,807$ & $21,486,890$ & $22,489,819$ & $28,906,439$ & 145 & 129 \\
\hline Indonesia & $21,404,547$ & $23,091,989$ & $24,019,723$ & $35,140,028$ & 108 & 146 \\
\hline Malaysia & 21,563 & 24,899 & 25,942 & 34,284 & 115 & 132 \\
\hline $\begin{array}{l}\text { The } \\
\text { Philippines }\end{array}$ & 44,245 & 52,560 & 54,228 & 74,203 & 119 & 137 \\
\hline Singapore & 40,838 & 54,568 & 57,572 & 70,704 & 134 & 123 \\
\hline Thailand & 89,141 & 105,117 & 109,533 & 137,588 & 118 & 126 \\
\hline Vietnam & $11,912,923$ & $19,281,532$ & $20,399,433$ & $31,369,228$ & 162 & 154 \\
\hline Canada & 37,344 & 46,652 & 47,396 & 49,357 & 125 & 104 \\
\hline USA & 39,176 & 48,070 & 48,887 & 50,836 & 123 & 104 \\
\hline France & 26,864 & 31,548 & 32,067 & 32,427 & 117 & 101 \\
\hline Germany & 26,328 & 29,325 & 30,507 & 33,869 & 111 & 111 \\
\hline Italy & 25,107 & 28,163 & 28,634 & 25,450 & 112 & 89 \\
\hline Netherlands & 29,920 & 36,323 & 37,542 & 38,429 & 121 & 102 \\
\hline Spain & 18,412 & 23,483 & 24,080 & 23,110 & 128 & 96 \\
\hline $\mathrm{UK}$ & 20,763 & 26,275 & 26,819 & 27,483 & 127 & 102 \\
\hline Japan & $3,717,615$ & $3,944,525$ & $4,011,484$ & $4,164,500$ & 106 & 104 \\
\hline
\end{tabular}

Processed from IMF, world economic outlook database, 2017

More important for our purpose is the revolution of rising expectations in Asia. As Table 1.3 shows, East Asian countries have done very well economically over the last two decades. It is true that the economic crisis in 1997-1998 devastated such East Asian countries as Thailand, Indonesia, South Korea and Malaysia. And yet, if we look at the ten-year period from 1996 to 2005, per capita GDPs expanded from 100 to 115-119 in Malaysia, Thailand, and the Philippines and more than doubled in China. Even Indonesia, the country which was hardest hit by the 1997-1998 economic and political crisis and went almost to the brink of national disintegration, saw its per capita GDP expand from 100 to 108. Even more important, all these countries did better in the second ten-year period from 2006 to 2015. Per capita GDPs expanded by $26-54 \%$ in Thailand, Indonesia, Malaysia, the Philippines and Vietnam, while China's per capita GDP more than doubled once again in the same period.

To put it differently, the standard of living in all these countries has improved enormously within the space of a generation. This has understandably given rise to optimism, people taking it for granted — or at least hoping — that their lives will be better tomorrow and that their children's lives will be far better than theirs. Of course we do not know what the future holds for us, but it is reasonable to expect that the kind of economic performance many countries and peoples in the region 
have experienced will be very hard to repeat in the coming years. There are signs that the Chinese economy has been slowing down, while economic performance of Southeast Asian economies has been uneven. The point is that the government will be held responsible if it cannot meet the kind of expectations its people have for improving their lives.

This is the reason the middle-income trap is now being debated widely as a major challenge in East Asia as well as elsewhere. Economists offer us advice on how to avoid the middle-income trap, telling us that human-resource and infrastructural development, inclusive growth and the creation of social safety nets are the way to go. Just as crucially, many societies in East Asia are aging over the coming fifteen to twenty-five years, if not earlier, and with only a few exceptions, they are aging without first having achieved high-income status. If we look at the timing in which each person belonging to the non-working-age population needs to be supported by less than two persons in the working age population, we see that Thailand is expected to cross this threshold in fifteen years, while China, South Korea and Vietnam will do so in twenty years. This means that social safety nets need to be put in place in the coming decade, and a lot more resources need to be invested to secure a minimum level of social safety for the aging population (Uemura 2015). In this sense, the future of Asia both nationally and regionally will depend very much on the sustainability and viability of productivity politics. With the kind of geopolitical structure and economic, political and cultural networks now in place in this region, individual states cannot afford to embark on nation-building and economic development in isolation.

This brings us to the final point we need to examine as a major challenge emerging states and economies in Asia face/offer. The twentieth century system of Pax Americana, the liberal democratic state, "the self-regulating market without the gold standard" and the market economy informed the modernization assumption that economic development will eventually lead to political modernization (i.e., democratization) because people who have attained the life of plenty would opt for freedom. But Singapore with its high-performance technocracy has long proven this assumption wrong. And now China, it seems, is confidently offering its people a similar social contract, no doubt in part learning from Singapore, that the party state will provide its people with a life of plenty and security, as long as they do not question the party state regime. To put it another way, China is offering the domestic systemic alternative of the party state cum socialist market economy (as opposed to the liberal democratic state cum market economy), which not a few emerging states in Asia and elsewhere may find more promising and attractive.

\subsection{The Shape of This Book}

Maier (2014) talks about modern nation-state formation in a world of war and competing states and in an age of blood and iron and rapid technological progress from the mid-nineteenth century to the 1970s. It was the long nineteenth century in which 
nation-states were fashioned in Europe and the collapse of Polanyi's nineteenthcentury civilization was synonymous with the collapse of Leviathan 2.0 in Europe.

In Asia, however, the story was different. The pre-history of emerging countries in this region consisted of the advent of imperial powers, bringing their Leviathan 2.0, to Asia and building modern state machines for colonial pacification, subjugation, and exploitation. As Takeshi Onimaru's chapter shows, the infrastructure of the modern state apparatus — tax collection and policing — was put in place in those years. Colonial economies were organized with the development of plantations and mines, sometimes through massive importation of labor, and directly connected with their respective metropolitan economies. This system of colonial states and economies as well as the British-led collective imperial system collapsed under Japan's onslaught during World War II.

After World War II, all of these countries went independent, and eventually all the countries, except North Korea, opted for controlled transformation through nation-building from above. Nationalism, seen as the force to move history forward, informed their nation-building projects, both from above and from below, and now inform the pursuit of power and rising chauvinism in China and some other countries. The developmental state was the name given to successful cases of controlled, catch-up transformation, while those which failed to deliver were condemned as purveyors of crony capitalism (Hau 2016). This template was recalibrated by the democratization of America's allies, but survives in China (and Vietnam) and is now celebrated as Beijing consensus (Halper 2011).

Asia is in transition. The balance of power is shifting fast, if the economic size (GDP in current USD prices) and the military spending are to be used as proxies for power. The Chinese economy is more than three times larger now (in 2015) than the Japanese economy and the Indian and ASEAN economies are expected to surpass the Japanese by the early 2020s. Chinese military spending is more than four times larger than Japan's, while Indian military spending has surpassed Japan's for some time. Emerging nations continue to face the challenge of not being bogged down in the middle-income trap and meeting people's rising expectations of a better life while investing more in the creation of social safety nets. And building its own domestic political and economic system on a social contract promising its people a life of plenty and security, China is offering a systemic alternative to the now passing long twentieth century system of the liberal democratic state and the market economy.

These conditions suggest that emerging nations and the region are confronting three major challenges. One is how to achieve economic growth and meet the growing expectations of the region's people to improve their living standards at a time when trade and capital flows are liberalized, people are moving across national boundaries in increasing numbers and becoming ever more aware of what is going on elsewhere in the world and exposed to images of affluence and consumption. The second challenge is how to ascertain the evolution of the regional order at a time when the balance of power is changing fast and China may be tempted to change the regional system to make it more hospitable to its hegemonic purposes. For individual emerging nations, this issue is posed as a question of maintaining balance in security in a time of increasing uncertainties while seizing the opportunities China offers for their own 
economic development. And finally China's promise of a life of plenty and security to its own people, if successful, will offer an alternative to states and peoples in this region and beyond. In sum, we may be facing yet another Polanyi moment, witnessing the collapse of the twentieth century system: the U.S. under President Trump may no longer have the political will to maintain Pax Americana, while China is intent on creating its own hegemonic sphere; the self-regulating market is under attack because of U.S. insistence on "fair and reciprocal" trade protectionism; the liberal democratic state built on the promise of the life of plenty and freedom is being challenged by technocratic party states built on the promise of a life of plenty and security; and finally the market economy under liberal democracy is being challenged by the socialist market economy in which the state and the economy are under party control and guidance. It should be clear, then, that whether emerging states, especially China, can overcome the middle-income trap, deliver on their promises of a life of plenty and meet the rising expectations of their people will have a huge bearing on the way in which the twentieth-first century system will be transformed.

The question of middle-income trap is often discussed as if it were merely an economic policy question of human-resource development, infrastructural development, inclusive growth, and social safety nets. But this question is closely connected, on the one hand, with the challenge that states face to meet the rising expectations of their own people, and on the other hand the state's external engagement in security and economic matters at the regional and global levels for its own gains. The core issues here are what kind of state is conducive to pursuing economic growth, what the purpose of politics is, and how this purpose defines state form, legitimacy, and allocation of scarce resources.

The developmental state had once offered itself as an answer to these core issues, and China still offers the developmental state model (now renamed the China Model) as a way of uplifting the standard of living of its people and enhancing its power and prestige without liberalizing political rights (Halper 2011). The developmental state defines the purpose of politics as nation-building and the pursuit of national economic growth as an important part of it. In so doing, it tries to contain, if not rule out, the "messiness" of politics arising from multiple claims made by multiple classes and social forces from across a broad spectrum of society. But resources are always limited. Government resource allocation - the issue of how and how much a government can allocate its resources to which sectors and for what purposes-is always and everywhere intensely political. Politics, which is sometimes defined as the authoritative allocation of scarce resources (Easton 1966), is by definition messy, and it is impossible, indeed futile, to remove that messiness from the political process, whether liberal democratic, authoritarian, or party state. Admittedly liberal democratic systems of government do not automatically foster high economic growth, nor is it a sure way to close the gap between the rich and the poor. The tension between democratic norms and economic growth and equity is even more strongly felt now in this globalizing world. This brings us back to a classic question of democracy and economic development, the long-term viability and sustainability of the productivity politics that has been the mainstay of this region since the 1960s/70s and is destined to haunt us still for some time to come. 
It is with these key questions in mind that all the chapters that follow are presented. In Chap. 2, Keiichi Tsunekawa defines and identifies twenty-nine emerging states and examines the general patterns of their economic development and sociopolitical changes in this age of globalization. Emerging states are in a good position to benefit from economic globalization because of their large domestic markets, abundant natural resources and/or appropriate technological capability. But upgrading their technological capability and strengthening their domestic production linkages, he argues, will be a big challenge in order for emerging states to advance further economically. He also underlines the strategic importance for emerging states to enhance redistributive measures and social linkages to address the gap between those who benefit from globalization and those who are left out. Meeting these challenges requires the delicate and politically adept coordination of interests among economic and social forces, and Tsunekawa concludes that the prospects of emerging states depend very much on the coordination capability of their public institutions.

Comparative history chapters follow the cross-national examination of emerging states and economies. In Chap. 3, Kaoru Sugihara examines Asia's regional path of economic development in a long historical perspective, focussing on trade, industrialization and the developmental state. In sharp contrast to many parts of Africa, Middle East and Latin America where local economies were integrated into the metropolis-led international economy as satellites, Asia's de facto economic integration took place in the era of collective imperialism because intra-Asian trade grew faster than world trade as well as Asia's trade with the West in 1880-1938. This was the regional context in which Asian industrialization happened. The growth of intra-Asian trade helped Japan's industrialization. When China went through importsubstitution industrialization in the interwar years, Japanese manufacturers expanded their exports of textile machinery to China. This marked the origin of 'flying geese' pattern regional industrialization. The post-war industrialization followed the same pattern. Intra-regional trade created a regional division of labour and mediated by merchant networks. Developmental states were instrumental in the mobilization of labour and capital. The development path of the countries in the Western Pacific rim became, at least in part, resource-intensive and growth-driven. In the recent years, China has expanded this model to integrate its inland regions and Eurasian neighbors into its growth orbit. This development, however, requires the mobilization of less tradable resources, such as water and eco-system services, put pressure on local resources, and raise questions about environmental sustainability. In conclusion, Sugihara argues that industrialization has to be sustainable both economically and environmentally, and at national, regional and global levels, if Asia's emerging states want to maintain developmentalism.

In Chap. 4, Takeshi Onimaru examines colonial state-building in Singapore and Hong Kong in comparative historical perspective. He notes two important differences in the revenue structures and policing processes of nineteenth-century Singapore and Hong Kong. Opium farming was the major source of revenue in Singapore, but not in Hong Kong. Secret societies were banned in Hong Kong, while they were tolerated in Singapore until the last decade of the nineteenth century. Onimaru explains the difference in political-economic structural terms. The Singaporean economy was 
built on entrepôt trade and inland plantation economy for China market. The colonial government outsourced revenue collection to opium farms. Chinese secret societies controlled inland plantation economy. Opium farmers relied on secret societies to sell opium to plantation workers under their control. The colonial government also outsourced the provision of social security and protection to secret societies. In contrast, Hong Kong was built on entrepôt trade, but did not have an inland plantation economy. Secret societies were seen as nothing but trouble-makers. The colonial government banned secret societies and fashioned a police force composed mainly of Chinese for the business of policing. The chapter provides useful insights on how and why colonial state building in Singapore and Hong Kong was different and underlines the geopolitical and political economic significance of distance between the two trading and financial centers and their most important hinterland, China, as well as their locations in what Sugihara calls Chinese trading networks.

In Chap. 5, R. Bin Wong looks at China in comparative historical perspective. He asks whether, and how, basic connections between imperial Chinese ideas about good governance, political economy and popular material welfare were reconfigured in the ideologies and institutions of development in China. He examines the imperial bureaucracy whose mission is geared to the material welfare of the population, the coalition of officials and local elites in pursuit of a shared Confucian agenda for maintaining social order, and the state campaigns for extraordinary projects. Wong notes that those approaches manifest themselves within very different ideological and institutional framework in Communist China. China's party-state aspires to achieve wealth and power. The pursuit of wealth in his view is closely connected to issues of distribution, raising living standards, and social security of the population, while the pursuit of power includes both domestic and external dimensions. Created by the social revolution from below, a communist-indoctrinated official elite had little to no potential for autonomous action under the strictures of party discipline for a long time. With the emergence of new social elites as a product of many years of economic reform and development, however, the question now being raised is how the relationship between party-state officials and social elites will stabilize and under what conditions and with what purpose of the state. These question are crucial for understanding the long term viability of the promise the party state offers to the population as social contract.

The nineteenth century witnessed great divergence in the economic fortunes of Europe and Asia. In Chap. 6, Sugata Bose underlines the critical importance of colonial rule for the great divergence. The post-Napoleonic years saw the transformation of British East India Company into a territorial state in India. Those years also saw Indian artisanal products losing their ability to compete in the global marketplace and the Company meeting its requirement of remittances to the metropolis through the forced cultivation of indigo and financing its China tea trade by establishing a government monopoly over opium. The mobility that characterized eighteenth-century rural society was replaced with the immobility and stern discipline of agricultural commodity production. The labor-intensive commercialization of agriculture took place on this basis of immobile servile labor. Peasant labor clung on to the basic means of production-land-but became increasingly dependent on merchant and 
usury capital. The political economy of late colonialism presented some marked departures from the classical patterns of the earlier era. The dislocations of World War I provided protection to India's cotton textile industry. The depression era witnessed a catastrophic price fall and a dramatic shrinkage in the availability of credit. With the outbreak of war in Europe a huge expansion in public expenditure triggered inflation. Colonial India had to pay for war expenditure here and now by printing rupees while sterling credits built up in the Bank of England. The colonial state also intruded into the food market to provision troops and industrial workers. The famine of 1943 shredded what little remained of the legitimacy of the British raj in India. In the postwar and post-independence era, India opted for the path of capital goods-led import-substituting industrialization. But the growth rate was sluggish. After the permits, licenses and subsidy raj was dismantled in 1991, however, the Indian economy has grown at a pace second only to China. Dynamic growth infused a new sense of confidence. Yet India's performance in the areas of basic education and health care for the poor has much to be desired. He concludes that India has prospered not through economic autarky, but by mustering political and cultural resources to set the terms of global engagement. In this process of denial colonized India suffered grievously. It is by engaging with the global economy and recovering its own agency that India is being able not just to ride the upswings of the global economy but also to reduce vulnerabilities to its more volatile downturns.

In the concluding chapter, Tetsushi Sonobe defines the middle-income trap as the failure of a middle-income country in moving into high-income status for many years. Applying empirical definitions of the middle-income trap, they suggest that some of the Asian as well as Latin American and Middle Eastern emerging economies might be in the trap. They argue the quality of education matters for economic growth, but question whether expansion in education is a major driver toward equal societies. Examining whether countries with higher education levels have more equal societies, they conclude that the results are mixed and that even though there is a direct correlation between education and economic equality, those who enjoy high educational attainment and quality tend to connect better globally and earn more than those not very well connected. This observation is relevant to China, which has the lowest high school enrollment among all the countries with comparable income level and where more than $30 \%$ of junior high school students drop out in poor rural areas. In such large emerging economies as China and India, many of their youth in rural areas might not be able to learn the required skills to secure decent jobs in the near future, a failure that may exacerbate both urban-rural income inequality and unemployment. They also underline the crucial importance of innovation. Confronted with rising labor cost, firms in middle-income economies find it hard either to compete with those in low-wage economies or with firms in technologically more advanced higher-wage economies. To examine ways to overcome this contradiction, Sonobe looks at three responses - substitution of expensive labor with capital, cost reduction measures, and product upgrading - and underline the importance of management. They also argue that the government's job in innovation is to reduce entry barriers (including import barriers), to put more competitive pressures on firms to improve their management and not to try to coordinate resource allocation for innovation. 
This book offers our take on what challenges China and other emerging states and economies confront now and in the coming years. It explores our ideas of emerging states and economies, their pre-history as well as the two largest emerging nations of China and India in historical perspectives, and the crucial importance of overcoming the middle income trap to meet the rising expectations of peoples for the future of Asia. In concluding this introductory chapter, I underscore the importance of states' ability to manage risks and uncertainties. We do not know what the future holds for us, but what we do now to manage risks and uncertainties internationally and domestically can lead us to a certain future and not to some other futures. Whether consciously undertaken or not, any attempt to manage risks and uncertainties is informed by normative thinking. It is important, therefore, to be aware of which norms inform our thinking and which norms at the end of the day will constitute the very foundation of our future life together.

\section{References}

Anderson, B. (1966). Japan, the light of Asia. In J. Silverstein (Ed.), Southeast Asia in world war II: Four essays. New Haven: Yale University Southeast Asia Monograph Series No. 7.

Anderson, B. R. O'G. (1991). Old state, new society: Indonesia's new order in comparative historical perspective. In Language and power: Exploring political cultures in Indonesia (pp. 94-120). Ithaca: Cornell University Press.

Anderson, B. R. O'G. (2014). Studies of the Thai state: The state of thai studies. In Exploration and irony in studies of siam over forty years (pp. 15-45). Ithaca: Cornell Southeast Asia Program.

Bacevich, A. J. (2016). America's war: For the greater middle east, a military history (p. 2016). New York: Random House.

Baldwin, R. (2016). The great convergence: Information technology and the new globalization. Cambridge, Massachusetts: The Belknap Press of Harvard University Press.

Baldwin, R., Forslid, R., \& Ito, T. (2015). Unveiling the evolving sources of value added in exports. Econ.hitu.ac.jp. Accessed on August 10, 2017.

Berger, S. R. (1997, June 6). Remarks by Samuel Berger assistant to the president for national security affairs. New York: Council of Foreign Relations New York.

Brzezinski, Z. (2008). Second chance: Three presidents and the crisis of American superpower. New York: Basic Books.

Cumings, B. (1997). Japan and northeast Asia into the twenty-first century. In P. J. Katzenstein \& T. Shiraishi (Eds.), Network power: Japan and Asia (pp. 136-168). Ithaca: Cornell University Press.

Easton, D. (1966). Varieties of political theory. New York: Prentice-Hall.

Fukuzawa, Y. (2013). Bunmei-ron no Gairyaku (originally published in Japanese in 1875, An Outline of a Theory of Civilization). Tokyo: Chikuma Shobo.

Halper, S. (2011). Pekin Konsensasu (Japanese translation of Beijing Consensus). Tokyo: Iwanami Shoten.

Hamashita, T. (1997). The intra-regional system in east Asia in modern times. In P. J. Katzenstein \& T. Shiraishi (Eds.), Network power: Japan and Asia (pp. 113-135). Ithaca: Cornell University Press.

Hau, C. S. (2016). People's power, crony capitalism, and the (anti-)developmental state. In J. P. S. Manzanilla, \& C. S. Hau (Eds.), Remembering/Rethinking EDSA (pp. 398-448), Mandaluyong, Philippines: Anvil. 
Helleiner, E. (1994). States and the reemergence of global Finance: From Bretton woods to the 1990s. Ithaca, NY: Cornell University Press).

Ikenberry, J. G. (Ed.). (2014). Power, order, and change in world politics. Cambridge, U.K.: Cambridge University Press.

Johnson, C. (1982). MITI and The Japanese miracle: The growth of industrial policy, 1925-1975. Stanford, CA: Stanford University Press.

Johnson, C. (1987). Political institutions and eonomic performance: The government-business relationship in Japan, South Korea, and Taiwan. In F. C. Deyo (Ed.), The political economy of the New Asian industrialization. Ithaca: Cornell University Press.

Katzenstein, P. J. (2005). A world of regions: Asia and Europe in the American imperium. Ithaca: Cornell University Press.

Katzenstein, P. J., \& Shiraishi, T. (1997). Conclusion: Regions in world politics: Japan and Asia-Germany in Europe. In P. J. Katzenstein \& T. Shiraishi (Eds.), Network power: Japan and Asia (pp. 341-381). Ithaca: Cornell University Press.

Kitaoka, S. (1999). Seito kara Gunbu he, 1924-1941 (in Japanese, From Political Parties to the Military, 1924-1941). Tokyo: Chuo Koron Shinsha.

Kupchan, C. A. (2014). Unpacking hegemony: The social foundations of hierarchical order. In J. G. Ikenberry, (Ed.), Power, order, and change in world politics. Cambridge, U.K.: Cambridge University Press.

Maddison, A. (1990). Dutch colonialism in Indonesia: A comparative perspective. In A. Booth, W. J. O'Malley, \& A. Weidemann (Eds.), Indonesian economic history in the dutch colonial era (pp. 322-335). New Haven, Connecticut: Yale University Southeast Asian Studies.

Maddison, A. (2015). Sekai Keizai-shi Gaikan Kigen 1 nen-2030 nen (Japanese translation of Angus Maddison's Contours of The World Economy, 1-2030 AD: Essays in Macro-Economic History). Tokyo: Iwanami Shoten.

Maier, C. S. (1978). The politics of productivity: Foundations of American international economic policy after world war II. In P. J. Katzenstein (Ed.), Between power and plenty: Foreign economic policies of advanced industrial states. Madison: University of Wisconsin Press.

Maier, C. S. (2014). Leviathan 2.0: Inventing modern statehood. Cambridge, Massachusetts: The Belknap Press of Harvard University Press.

Mann, J. H. (1999). About face: A history of America's curious relationship with China, from Nixon to Clinton. New York: Alfred A. Knopf.

Mastanduno, M. (2014). Order and change in world politics: The financial crisis and the breakdown of the US-China grand bargain. In J. G. Ikenberry, (Ed.), Power, order, and change in world politics. Cambridge, U.K.: Cambridge University Press.

Metcalf, B. D., \& Metcalf, T. R. (2012). A concise history of modern India (3rd ed.). New York: Cambridge University Press.

Milanovic, B. (2016). Global inequality: A new approach for the age of globalization. Cambridge, Massachusetts: The Belknap Press of Harvard University Press.

$\mathrm{Nu}$, U. (1975). U Nu: Saturday's son. New Haven: Yale University Press.

Okamoto, R. (2016). Chugoku no Tanjo (in Japanese, The Birth of China). Nagoya: Nagoya University Press.

Polanyi, K. (2001). The great transformation: The political and economic origins of our time. Boston: Beacon Press.

Rush, J. (1990). Opium to java: Revenue farming and colonial enterprise in colonial Indonesia, 1860-1910. Ithaca: Cornell University Press.

Shiraishi, T. (2000). Umi no Teikoku (in Japanese, Empires of the Seas). Tokyo: Chuo Koron-sha.

Shiraishi, T. (2005). The Asian crisis reconsidered. In P. N. Abinales, N. Ishikawa, \& A. Tanabe (Eds.), Dislocating nation-states: Globalization in Asia and Africa (pp. 17-40). Kyoto: Kyoto University Press.

Shiraishi, T. (2012). The rise of china and its implications for East Asia. In P. J. Katzenstein (Ed.), Sinicization and the rise of China: Civilizational processes beyond East and West (pp. 120-149). London and New York: Routledge. 
Shiraishi, T. (2016). Kaiyo Asia vs. Tairiku Asia (in Japanese: Maritime Asia vs. Mainland Asia). Kyoto: Minerva.

Shiraishi, T., \& Hau, C. S. (2010). Only yesterday: China, Japan and the transformation of East Asia. In Z. Yangwen, H. Liu, \& M. Szonyi (Eds.), The cold war in Asia: The battle for hearts and minds (pp. 25-38). Leiden and Boston: Brill.

Suehiro, A. (Ed.). (1998). 20-seiki Sistem: Kaihatsu-shugi (in Japanese, The 20th Century System: Developmentalism). Tokyo: Institute of Social Sciences, The University of Tokyo.

Takagi, Y., Kanchoochat, V., \& Sonobe, T. (Eds). (2018). Developmental state building: The politics of emerging economy. Tokyo: Springer, Emerging-Economy State and International Policy Studies.

Temin, P., \& Vines, D. (2014). Riida naki Keizai: Sekai wo Kiki kara sukuu tame no hosaku. Tokyo: Nihon Keizai Shimbun-sha. Japanese translation of The Leaderless Economy: Why the world economic system fell apart and how to fix it. Princeton and Oxford: Princeton University Press, 2013.

Trocki, C. (1999). Opium, empire and the global political economy: A history of the Asian opium trade, 1750-1950. London and New York: Routledge.

Ueda, M. (2005). Umi to Teikoku: Min Shin Jidai (in Japanese: Seas and the Empire: under the Ming and the Qing). Tokyo: Kodansha.

Uemura, Y. (2015). Fukushi no Asia (In Japanese: Welfare in Asia). Nagoya: Nagoya University Press.

van Zanden, J. L., \& Daan, M. (2012). An economic history of Indonesia, 1800-2012. New York: Routledge.

Open Access This chapter is licensed under the terms of the Creative Commons AttributionNonCommercial-NoDerivatives 4.0 International License (http://creativecommons.org/licenses/bync-nd/4.0/), which permits any noncommercial use, sharing, distribution and reproduction in any medium or format, as long as you give appropriate credit to the original author(s) and the source, provide a link to the Creative Commons license and indicate if you modified the licensed material. You do not have permission under this license to share adapted material derived from this chapter or parts of it.

The images or other third party material in this chapter are included in the chapter's Creative Commons license, unless indicated otherwise in a credit line to the material. If material is not included in the chapter's Creative Commons license and your intended use is not permitted by statutory regulation or exceeds the permitted use, you will need to obtain permission directly from the copyright holder.

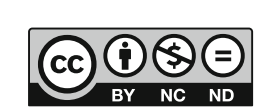




\title{
Chapter 2 \\ Globalization and the Emerging State: Past Advance and Future Challenges
}

\author{
Keiichi Tsunekawa
}

\begin{abstract}
This chapter defines and identifies twenty-eight "emerging states" and depicts the general patterns of their economic development and sociopolitical change in relation to institutional and economic globalization. These emerging states have been able to benefit from economic globalization but have avoided being constrained by institutional globalization because they have been able to attract global traders and investors by offering advantages, such as large domestic markets, abundant natural resources, appropriate technological capability, or a combination thereof. In the final analysis, however, upgrading the technological capability of domestic firms and labor and strengthening domestic production linkages will be crucial for the emerging states to further advance economically. They will also need to enhance redistributive measures and reinforce social linkages by narrowing the gap between the globally integrated populations and regions and those that are left behind. Both kinds of linkage strengthening require the close coordination of interests among economic and social forces such as large enterprises, local suppliers, workers, the middle class, and disadvantaged people. This chapter argues that the successful coordination of such interests requires the involvement of public institutions and is deeply affected by firm-government relations, middle-class conservatism, populist mobilization, institutional and ideational legacies from the past, and political leadership for institution- and coalition-building. These topics should be among the priority areas of scholarship for future emerging-state studies.
\end{abstract}

\subsection{Introduction}

Terms such as emerging economy or emerging-market economy have been used mostly in journalism or the business world. As such, they have seldom been subject to scholarly scrutiny. To begin with, the exact meaning of "emerging" has never been clarified. There is only a vague consensus that these economies are highly attractive

K. Tsunekawa $(\bowtie)$

National Graduate Institute for Policy Studies, Tokyo, Japan

e-mail: k-tsunekawa@grips.ac.jp

(C) The Author(s) 2019

T. Shiraishi and T. Sonobe (eds.), Emerging States and Economies, Emerging-Economy

State and International Policy Studies, https://doi.org/10.1007/978-981-13-2634-9_2 
for global traders and investors. Furthermore, as the terms "emerging economy" or "emerging market economy" illustrate, an overwhelming focus has been placed on the economic development of certain countries or regions that are supposed to be "emerging." In practice, economic development is frequently accompanied by sociopolitical transformation, which in turn either fosters or constrains the future trajectory of economic development. Furthermore, rapid economic development of certain countries frequently has serious repercussions for security relations among the nations. For this reason, I use the term emerging "state" instead of emerging "economy" in this chapter. 1

The purpose of this chapter is threefold: first, to define and identify the "emerging state;" second, to clarify the nature of their development in economic, social, and political terms; and third, to explore the kinds of challenges they face as they develop and achieve higher levels of economic and social complexity. As the "emerging" phenomenon most noticeably occurred in the 1990s and 2000s-during which time the pace of the global exchange of goods, money, human talents, and information quickened and global trade increased exponentially-I will examine it by looking closely at its relationship with globalization. The emerging states have been among those most deeply integrated into the global economy and have consequently benefited from and been constrained by globalization.

Identifying emerging states, just like defining "developing countries" or "middleincome countries," is a risky practice because a certain arbitrariness is unavoidable in the selection of categorization standards. However, in the following section, I will venture to introduce certain standards and to identify twenty-eight countries as "emerging states."

Before proceeding, I should clarify what this chapter is not about. It does not attempt any empirical analysis that rigorously tests mutual or causal relationships among various factors. The samples are too selective (they do not contain "nonemerging" states) and the potentially relevant variables (economic, social, political, and institutional) are too diverse to allow me to design a meaningful empirical analysis. This chapter will only try to depict general patterns of economic development and sociopolitical change that have been observed in the selected emerging states.

On the other hand, this chapter is also not a small-N study. It covers as many as twenty-eight countries, and therefore certain details and nuances will have to be compromised. It is not based on original research but relies heavily on secondary materials. The main goal of the chapter is to draw a big picture illustrating the "emerging" phenomenon and indicating directions of future research on the emerging state.

Third, this chapter does not directly deal with impacts of the "emerging" phenomenon on the inter-state relations. The focus of this chapter is the other way around: how and why global factors have affected the "emerging" phenomenon.

\footnotetext{
${ }^{1}$ The entities that are not "independent" national states under the United Nations system will be treated as "emerging states" for the sake of simplicity if their economy operates in a sufficiently autonomous manner (without other countries' intervention).
} 
This chapter is organized in the following manner. In Sect. 2.2, I will present and justify my definition of the emerging state and will select twenty-eight states that fit that definition for the period of 1990-2014. I will also point out that such attempts at defining the emerging state cannot be free from arbitrariness and that the list of the potential emerging states can be expanded by broadening the definition. In addition, Sect. 2.2 will mention that the "emerging" phenomenon is not new but there are historical antecedents during both the pre-WWII and post-WWII periods.

Section 2.3 will explore the existing literature related to the nature of globalization, distinguishing institutional globalization and economic globalization. This section will explore three different positions regarding the economic, social, and political impacts of globalization upon individual national states: optimist, alarmist, and cautious.

In Sect. 2.4, I will examine the extent to which the positive and negative views of globalization are supported by what has actually happened in the last twenty to twenty-five years, specifically by examining the relationship between the extent of globalization on the one hand and economic growth, social improvement, and political transformation (democratization) on the other. This section will demonstrate that the emerging states have been able to gain economic benefits from economic globalization but have avoided being constrained by institutional globalization because they were able to attract global traders and investors by offering certain advantage factors such as large domestic markets, natural resources, and the requisite technological capability, or a combination thereof. However, this section will point out that mere dependence on natural-resource export or domestic market does not guarantee a long-term economic development. As for social and political repercussions of the globalization, Sect. 2.4 will elucidate that no simple pattern is observed.

Section 2.5 will then attempt to explain the divergence of globalization's impacts on the emerging states by focusing on institutional diversities. Since the period of rapid globalization is also regarded as that of political regime changes (to democracy or pseudo-democracy), a special attention will be paid to examining whether such political change is associated with the economic and social performance of the emerging states.

Section 2.6 is concerned with the challenges emerging states face while attempting to realize further economic and social advancement. This section will argue that, in the final analysis, the prospects of emerging states largely depend on the coordination capability of their public institutions. These public institutions must help upgrade the technological capability of domestic firms and the domestic workforce and must strengthen redistributive measures for populations and regions left out of the global integration process, thus broadening and deepening domestic linkages and cohesion. Section 2.6 will then indicate five factors that can affect the coordination capability of public institutions in the emerging states: government-private sector relations, middle-class conservatism, populist mobilization, institutional and ideational legacies from the past, and the nature of the country's political leadership.

In the concluding section, I will argue that the enhancement of domestic linkages is not only an economic or technical matter but is also deeply connected to political factors. The reason is that pro-linkage endeavors require complex coordination 
among many groups across the social spectrum. This section will also point out that the five factors that can affect such coordination in the emerging states should simultaneously be among the priority areas of scholarship for future emerging-state studies.

\subsection{Which Countries Are the Emerging States?}

The attempt to categorize countries (economies) into specific groups is always accompanied by arbitrariness with regard to the standards used for such categorization. The selection of emerging states is no exception. The BRICs and G20 groupings are too narrow to cover many other important countries in the world. I contend that there are two basic reasons why emerging states have attracted broad attention in the contemporary world. These reasons should be taken into account in the identification of emerging states. First, they were "developing" countries before the 1980s but are now regarded as "emerging" because their speed of economic catch-up with the "advanced" industrial countries is noticeably high. Second, as their share in the global economy has expanded, they are regarded as the partners (no longer the followers or beneficiaries) of "advanced" countries that must share certain responsibilities in the effective governance of various aspects of the global economy. For these two reasons, I use GDP per capita and the size and growth rate of GDP (relative to those of the "advanced" countries) as the standards for identifying emerging states.

First, since the emerging states were "developing countries" before the 1980s, the countries whose per capita GDP in 1990 was greater than that of Singapore (which was the forerunner among the contemporary developing countries and had attained "high-income country" status in the early 1980s) must be excluded. ${ }^{2}$

Second, for a country to be called "emerging," it must have achieved a GDP growth rate greater than the growth rate of "advanced" countries for the 1990-2014 period. Here, I use the US growth rate (78.2\% increase between 1990 and 2014) as the benchmark.

Third, the size of the country's economy (which is a proxy of its relative importance in the world) is considered. It is here that the greatest arbitrariness occurs, but I temporarily set $1.0 \%$ of the US GDP in 2014 as the standard by which I selected the emerging states.

This exercise leaves twenty-seven countries (economies). I have added Russia to this list, even though its growth rate for the period 1990-2014 (18.7\%) was substantially lower than the US growth rate for this period. We need to consider the exceptionally steep decline of the Russian economy in the 1990s due to the breakdown of the Soviet Union. It shrunk by $25.9 \%$ between 1990 and 2002. If the growth rate is calculated only for 2003-2015, Russia recorded 60.3\% vis-à-vis US's 23.8\%. Moreover, the Russian economy - the size of which was $10.4 \%$ of US GDP in 2014-is still the fourth largest among the emerging states and is too large to be excluded.

\footnotetext{
${ }^{2}$ Singapore's per capita GDP in 1990 was $\$ 11,865$ (in current USD).
} 
Table 2.1 Emerging states by region and income level

\begin{tabular}{|c|c|c|c|}
\hline & High income & Upper middle income & Lower middle income \\
\hline East and South Asia & $\begin{array}{l}\text { Singapore } \\
\text { South Korea } \\
\text { Taiwan }\end{array}$ & $\begin{array}{l}\text { Malaysia } \\
\text { China } \\
\text { Thailand }\end{array}$ & $\begin{array}{l}\text { Indonesia } \\
\text { Philippines } \\
\text { India } \\
\text { Pakistan }\end{array}$ \\
\hline Latin America & Chile & $\begin{array}{l}\text { Brazil } \\
\text { Argentina } \\
\text { Mexico } \\
\text { Venezuela } \\
\text { Colombia } \\
\text { Peru }\end{array}$ & \\
\hline $\begin{array}{l}\text { Former USSR and } \\
\text { Eastern Europe }\end{array}$ & $\begin{array}{l}\text { Poland } \\
\text { Russia }\end{array}$ & Kazakhstan & \\
\hline $\begin{array}{l}\text { Middle East and } \\
\text { North Africa }\end{array}$ & Saudi Arabia & $\begin{array}{l}\text { Turkey } \\
\text { Iran } \\
\text { Iraq } \\
\text { Algeria }\end{array}$ & Egypt \\
\hline Sub-Sahara Africa & & South Africa & Nigeria \\
\hline
\end{tabular}

Note Countries in thick letters are G20 members. Source Appendix 1

On the other hand, Vietnam and Bangladesh are excluded, although their growth rates were more than triple that of the United States during the period of 1990-2014. This exclusion is because their GDPs had not yet reached the $1.0 \%$ benchmark by 2014. They will certainly reach that threshold before long. The list of next-generation emerging states (including Vietnam, Bangladesh, Ethiopia, Uganda, and Ghana) is long, ${ }^{3}$ but most of them are small countries whose relations with the global economy and their mode of growth seem to be quite different from the mostly upper-middle or high-income countries that I chose as emerging states. I will return to this subject in the next section.

Consequently, as of 2014, there are twenty-eight countries or economies that form the group of "emerging states" (Table 2.1). Regionally, Asia (both East and South) contains the greatest number of emerging states, followed by Latin America and MENA (Middle East and North Africa). Fifteen out of twenty-eight countries belong to the higher-middle-income category defined by the World Bank. ${ }^{4}$ Seven are categorized as high-income economies and six as lower-middle-income countries. The list covers all eleven G20 members that were not "advanced" countries before the mid-1980s.

Although this chapter focuses on the contemporary emerging states, it is worth mentioning that there are historical antecedents for them. Fig. 2.1 shows the size

\footnotetext{
${ }^{3}$ The countries whose growth rate was more than double the US rate between 1990 and 2014 number as many as thirty-nine without counting the current emerging states.

${ }^{4}$ As for standards set by the World Bank to classify income groups in different years, refer to http://databank.worldbank.org/data/download/site-content/OGHIST.xls (accessed on September $18,2016)$.
} 


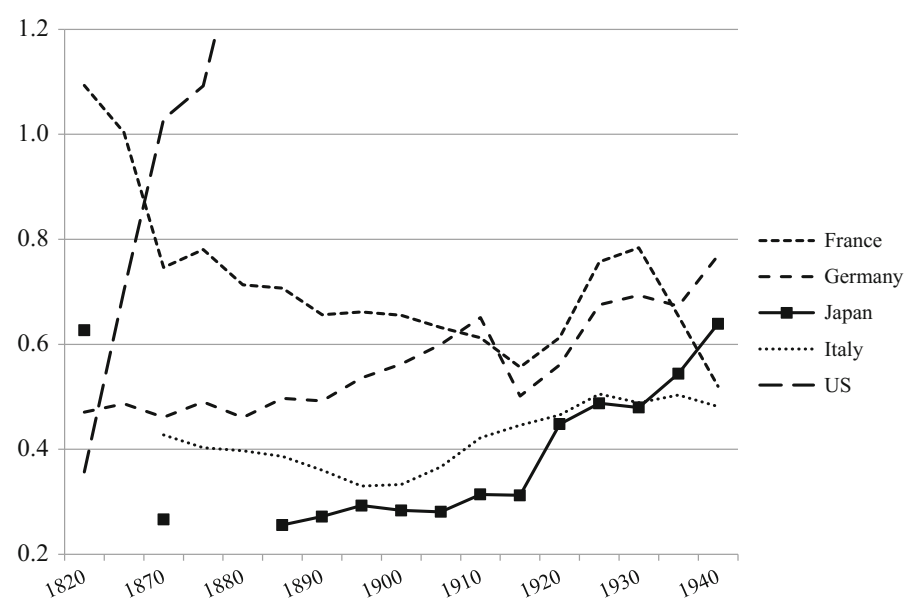

Fig. 2.1 Relative size of GDP(United Kingdom = 1.0). Source Own calculation based on Maddison (1995, Table C-16)

of GDP of several major countries relative to that of the United Kingdom for the period covering 1820-1940. The US economy surpassed the UK's by 1870 while France declined over a century vis-à-vis the United Kingdom. The growth trajectory of Germany, Italy, and Japan demonstrates a long-term catching-up with the United Kingdom although the starting years are different for the three. These three countries and the United States are clear historical cases of the emerging states. However, a similar pattern is not observed when the United States is used as the benchmark country. Figure 2.2 shows that Soviet Union, France, Germany, Italy, and Japan experienced the narrowing of economic gap with the United States before the WWII, but such experience lasted only for ten to twenty years. After a sharp economic decline during the war, these countries restarted the catching up. However, except for Japan, they could never advance beyond the prewar peak. In that sense, Japan was the only clear case of the emerging state vis-à-vis the United States.

The developing countries/economies have a better performance in the postwar period in terms of the catching-up with the United States. Many of the twenty-eight emerging states listed in Table 2.1 started their catching-up process much earlier than 1990. Among twenty-six countries for which data for earlier periods are available, twenty (mostly from Asia, Middle East, and North Africa) recorded economic growth greater than the United States in 1960-1990. ${ }^{5}$ What happened after 1990 is the spread of the "emerging" phenomenon to cover the whole developing areas.

\footnotetext{
${ }^{5}$ This observation results from the author's calculation based on the GDP data from World Bank's World Development Indicators database and Maddison (1995, Table C-16).
} 


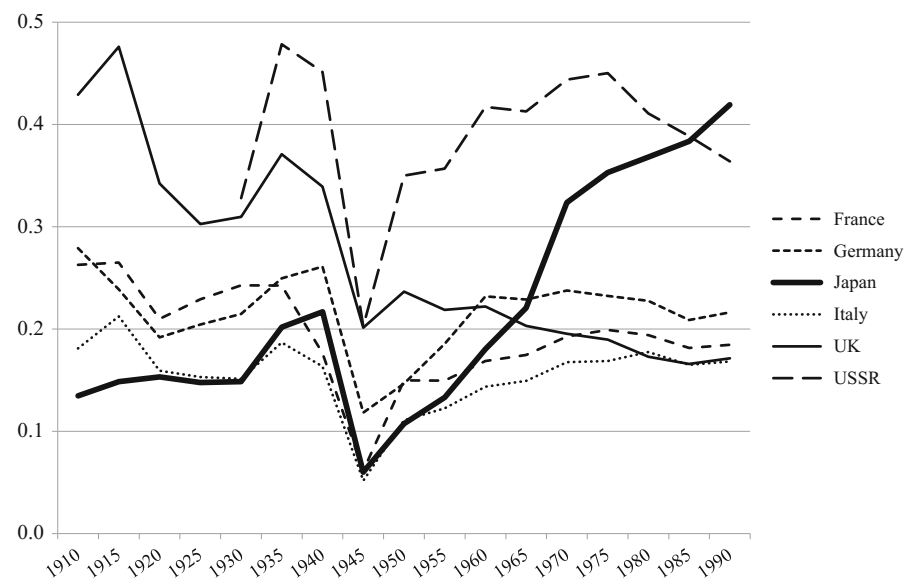

Fig. 2.2 Relative size of GDP (United States =1.0). Source Own calculation based on Maddison (1995, Table C-16)

\subsection{Globalization and Its Anticipated Impacts on the Emerging States}

\subsubsection{Anticipated Impacts of Globalization}

As the world-wise spread of the "emerging" phenomenon occurred in the 1990s and 2000s in which the speed of globalization quickened, it will be legitimate to inquire of impacts of globalization on the emerging states. In practice, globalization has been one of the most popular topics in both the scholarly and business circles during the last twenty to thirty years.

There are three different views — optimistic, alarmist, and cautious — on how globalization has affected national states including the emerging states. The optimistic view, which is especially popular among business people, regards globalization as highly beneficial to any country in the world. Kenichi Ohmae's books $(1990,1996)$ fully embody this view. He argues that the intensified competition over markets (for both final and intermediate goods) has forced firms to search for business partners beyond borders to reduce fixed costs. Economic activities have become borderless and as a consequence national states are no longer the main actors when it comes to protecting people's well-being. Interventions by national states generally interfere with efficient production and distribution by global economic actors and serve to reduce overall welfare.

In contrast to the first view, the second view is rather pessimistic in its evaluation of globalization. This view does not deny that globalization has brought certain benefits to individual national states. However, it is highly concerned about globalization's 
negative impact on the policymaking autonomy of individual national states regarding economic and social matters. This concern was strongly expressed by Susan Strange:

[The] impersonal forces of world markets, integrated over the postwar period more by private enterprise in finance, industry and trade than by the cooperative decisions of governments, are now more powerful than the states to whom ultimate political authority over society and economy is supposed to belong. (Strange 1996, p. 4)

She argues that decisions about production, trade, investment, and finance are increasingly controlled by multinational corporations (MNCs) and their global networks. Consequently, the authority of national governments is heavily constrained in many policy fields including national currency, development strategy, economic cycles, social welfare, tax, trade, and labor. As a result, damages are incurred, especially against the interests of workers, citizens, and small-sized firms. If a national government attempts to strengthen laws and regulations governing MNCs, they will simply transfer their activities to some other country with a weaker regulatory regime (Strange 1996, Chaps. 4 and 5).

Concerns about the adverse effects of globalization on national policymaking autonomy are shared by Dani Rodrik in his early work (1997). Echoing Polanyi's argument about the "double movements" (Polanyi 2001 [1944]), Rodrik warns that the national government's capacity to provide social insurance is being curtailed by the increasing mobility of capital, because such mobility has left a large portion of the tax base unmoored. As social insurance has been "one of their [governments'] central functions and one that has helped maintain social cohesion and domestic political support for ongoing liberalization," the shrinkage of that function will lead to the enhancement of anti-globalization voices (Rodrik 1997, p. 6, pp. 70-71).

Thomas Friedman, a journalist for the New York Times, also believes that space for policy choices by national governments has been narrowed by globalization. The global economy functions as a "golden straitjacket" for which only one size is available. A national government that fails to fit itself into that size will see investors leave its country and its economy fall into stagnation (Friedman 1999/2000, pp. 103-4). He warns that the people who seek trust and security from traditional identities (such as family, community, and nation) rather than from the global economy may revolt against global economic forces unless an adequate social safety net is made available (Friedman 1999/2000, p. 41, pp. 424-25).

In addition to the social effects of globalization, Rodrik mentions its political effects. Rodrik expresses his preference for democracy as a political institution that can process and aggregate local knowledge and needs in order to realize economic growth that is inclusive, resilient, and secure over the long term (Rodrik 2007, Chap. 5). However, he believes that there is a contradiction between democracy and globalization. Actually, he writes about a "political trilemma of the world economy," arguing that a country can have only two of the following three: "hyperglobalization," "democratic politics," and the "nation state" (Rodrik 2011, Chap. 9). In practice, the option of not having the national state is unavailable because, as Rodrik himself admits, a strong global governance regime supported by equally strong global democratic societies is too unrealistic. I would argue that the dilemma 
between democracy and globalization, rather than a trilemma, is the real problem. To solve this dilemma, Rodrik proposes moderating the application of global rules (that is institutional globalization) (Rodrik 2011, Chap. 12). This reasoning leads us to question whether democracy must be compromised if institutional globalization cannot be scaled down.

The third view on the impact of globalization shares with the second view a concern about its negative effects but differs in its admission that the constraints of globalization are not as strong as suggested by the second view. This third view leaves enough room for policy and institutional choice, at least for certain countries. It recognizes differentiated impacts of globalization for different countries.

For instance, Mosley (2003) investigated the relationship between global investors' behavior and the degree of national policy autonomy through quantitative analyses of government bond rates and interviews with sixty-four executives of major financial firms and rating companies. Mosley concluded that the executives of these international companies only consider key macroeconomic indicators such as inflation and budget deficit levels when making their investment decisions in "advanced" capitalist countries. Consequently, national governments in these countries can have a certain amount of autonomy to satisfy domestic necessities in the fields of taxation, labor-market regulation, and social welfare. However, emerging market governments face greater constraints because investors take into consideration many dimensions of government policy when they make asset allocation decisions. In the same line of argument, Wibbels (2006, p. 462) points out that the fiscal policy of developing countries tends to be procyclical (not countercyclical) because their access to international credit markets is limited during economic downturns. ${ }^{6}$ Mosley, however, observes that international investors' behavior in different emerging market countries is not monolithic. It diverges depending upon their evaluation of the credit risks of different regions and countries (Mosley 2003, Chap. 4).

During their discussion of global constraints (or the lack thereof) upon national political regimes, Acemoglu and Robinson distance themselves from Rodrik's view of democracy-globalization dilemma and admit the theoretical possibility that globalization fosters democracy because the expansion of global trade in poor countries "should reduce the income gap between the poor who earn their living from labor and the rich who are the capital holders" (2006, p. 322). This income gap reduction will moderate the behavior of the rich and the poor to the extent that peaceful coexistence becomes possible. They also infer that the increase in capital mobility makes democracy less threatening (and therefore more acceptable) to elites because they can expect that governments, fearing capital flight, will avoid heavy capital controls even under local democratic pressure to move in that direction. Acemoglu and Robinson (2006, Chap. 10), however, call for caution, observing that the relationship between global trade/investment and democracy has not yet been conclusively established. It depends on many factors, including the relative abundance of production factors, initial income distribution, and the distributional impacts of capital mobility.

\footnotetext{
${ }^{6}$ Kaplan (2013) makes a similar argument about countries in Latin America.
} 
Differing from the work of Mosley and that of Acemoglu and Robinson, who view the impact of globalization from the perspective of global opportunities (or constraints), many authors emphasize the importance of national political and institutional arrangements to explain the differing performances of national states that compete under similar global constraints. For instance, in his 2007 publication (originally written in 2005), Dani Rodrik provides a view that is less pessimistic than that of his other works. He argues that there can be "many recipes" in "one economics." If developing countries build appropriate institutions that respond to their national needs and conditions, they will be able to skirt global constraints and utilize the global economy for their own benefits.

Searching for national institutions suitable for economic development, Doner and his associates, who are concerned about the economic slowdown (that came to be known as the "middle-income trap" after 2007), emphasize the importance of institutions that foster the technological advancement of national firms and the labor force, thereby helping a country move up in the global production networks (Doner and Ramsay 2003; Doner et al. 2005; Doner 2009, 2015; Doner and Schneider 2016). For these authors, strengthening domestic linkages through interest coordination is essential. Workers and managers must cooperate on the shop floor to improve productivity and process technologies. Upstream firms and downstream firms must coordinate the scale, scope, and timing of investment and production. They may also need to compromise concerning the reduction of import tariffs at different stages of the production chain. Furthermore, to increase the amount of highly skilled human capital available, government budgets for higher education and technical training must be increased. Research and development $(\mathrm{R} \& \mathrm{D})$ budgets also need to be expanded. However, to increase these budgets, the government must either raise taxes or reduce other expenditures. Somebody needs to shoulder the burden. In this sense, as Doner and Schneider (2016) properly observed, technological upgrading is a highly political endeavor.

\subsubsection{Two Aspects of Globalization and the Emerging States}

So far, we have treated globalization as a single unified process. However, to understand the nature of impacts of globalization on the emerging states, it is important to distinguish two different aspects of globalization: institutional and economic. Institutional globalization is the spread of global standards and rules mostly set by intergovernmental negotiations led by the advanced countries. The rules set by the WTO concerning trade and intellectual property rights are typical expressions of institutional globalization. Market-oriented reforms required by the IMF and other global actors in exchange for financial support are another example of institutional globalization.

Economic globalization is the expansion of global transactions. As many studies of the global production network (GPN) point out, this process of economic globalization is mostly based on the economic activities of private firms and has been 
fostered by the spread of complex networks of firms beyond borders, especially since the 1990s.

The development of scholarly studies of the GPN has been well-documented in Coe and Yeung's comprehensive work (Coe and Yeung 2015). The source of GPN development is the fragmentation (vertical disintegration) of the production process and the transfer of a part of the process (assembly and/or parts production) abroad from the "advanced" industrial countries. Helped by the increasing modularization of parts and components and by the further development of information and transportation technologies, leading firms of the "advanced" countries shifted larger segments of their operations to locations where they could have greater global competitiveness in terms of market access, production costs, and the availability of technology. The leading firms increasingly specialized in those segments in which they possessed the greatest core competences, such as product development, the production of core products, brand management, and global marketing. This specialization left a large portion of manufacturing activities and business support services within the host countries.

Foreign direct investment (FDI) plays an important role in the formation of the GPN. However, according to Coe and Yeung (2015) and Yeung (2016), the GPN does not necessarily need subsidiaries of the leading firms to be established in the host countries, because, as the technological capability of local firms and workers improves, partnership without ownership (including outsourcing, contract manufacturing, and licensing arrangement) has increased between the leading global firms and local firms. In some cases, this partnership has reached the stage in which not only production but also product design and development are entrusted to the emerging partners.

The two aspects of globalization mentioned above are anticipated to affect the emerging states differently from how they affect the "advanced" countries and the less developed ones.

Institutional globalization demands more from the emerging states than the less developed countries because the emerging states grow and catch up quickly with the "advanced" countries, causing frequent trade disputes. The advanced countries and international organizations demand stricter application of the global trade rules from the emerging states, including tariff reductions, implementation of intellectual property rights, equal treatment of domestic and foreign firms, and the reduction of non-trade barriers.

The emerging states also tend to be subject to greater disciplinary pressure from the IMF and other global actors because the creditworthiness of their public and private sectors attracts a large amount of foreign financial capital while their economies are still vulnerable to sudden shocks. As shown by the Latin American debt crisis in the 1980s and the Asian financial crisis (AFC) in the 1990s, once large amounts of foreign funding start to exit or cease to come in, the indebted countries are forced to adopt free market-oriented policies such as fiscal balance, reduction of subsidies, market-based adjustment of domestic prices and exchange rates, and privatization (Teichman 2001, Chap. 3). 
Many less developed countries have also fallen into national bankruptcy. However, due to the small size of their economies, the global impact of their crises are minimal and consequently draw little international attention except on the issue of destitution. As far as the less developed countries are concerned, since the late 1990s policies demanded by the international organizations have focused more on poverty reduction than on market-oriented reforms (World Bank 2000).

The "advanced" countries are not free from trade disputes or financial crises, as shown by the Japan-United States trade friction in the 1980s and 1990s, the Lehman Brothers shock, and the European debt crisis in the 2000s. However, the constraints imposed by institutional globalization are weaker for them because "advanced" countries generally started institutional liberalization much earlier than the emerging states and attained high levels of liberalization by the 1990s. Their requests for the IMF's help are also less frequent.

With regard to economic globalization, the emerging states are deeply involved in the GPNs, a contemporary incarnation of economic globalization. Some of them started to build their manufacturing might by accepting FDI and/or participating in outsourcing networks and have since deepened their integration into the GPNs as they have moved up the global value chain to the middle or higher value-added sectors. In the process, some of them are supposedly susceptible to the "middle-income trap." A country (or economy) falls into this trap when, after having experienced years of high growth, long-term stagnation or decline sets in. Such a situation emerges when middle-income countries are "squeezed between the low-wage poor-country competitors that dominate in mature industries and the rich-country innovators that dominate in industries undergoing rapid technological change" (Gill and Kharas 2007, p. 5) due to the difficulty in moving up in the GPNs in terms of technological capacity (as for the middle-income trap, c.f. Yusuf and Nabeshima 2009; Doner 2009; Ohno 2009; Kohli et al. 2011; Felipe et al. 2012; Aaron et al. 2013; Gill and Kharas 2015).

The less developed countries and the "advanced" countries are also involved in economic globalization. The former, however, are integrated into lower value-added segments of the GPNs as labor-intensive manufactures or natural-resource exporters. The advanced capitalist countries are hosts for many global lead firms that compete for technological breakthrough.

In short, the emerging states are in the middle ground, being subject to strong pressures for institutional globalization and for specific adjustment for economic globalization.

\subsection{Actual Impacts of Globalization on the Emerging States}

The purpose of this section is to determine whether the impacts anticipated by the previous literature are congruent with what has actually happened in the emerging states. As I pointed out in the first section, my purpose is not to map exact correlations 
between globalization and economic, social, and political transformation but rather to observe general patterns across many emerging states.

\subsubsection{Globalization and Economic Growth}

The fact that the emerging states have been rapidly catching up with the "advanced" countries signifies that their economic growth has not been blocked by globalization. However, a closer examination is necessary to determine the extent to which globalization has been associated with a high level of economic performance of emerging states.

This is where globalization is divided into institutional globalization and economic globalization. To measure the degree to which each emerging state is exposed to institutional globalization (i.e., actual compliance with global rules of economic transaction), I use the Economic Freedom Score provided by the Heritage Foundation because, unlike other similar indicators (which attempt to measure broad business environments), this indicator is constructed using only indices that measure market freedom, such as property rights, trade and investment openness, fiscal balance, and labor market flexibility. On the other hand, I will measure economic globalization using two indicators: the ratio of trade to GDP and the ratio of inward FDI to GDP. All measures are calculated for the twelve-year period from 2003 to 2014 (see Appendix 2).

Clearly, Singapore is an exceptional case. Its trade and FDI ratios to GDP are abnormally high and could distort the whole analysis. For instance, the correlation coefficient between the trade ratio and the FDI ratio is very high $\left(\mathrm{R}^{2}=0.80\right)$ if Singapore is included, but it goes down sharply (to 0.09) if Singapore is excluded. Hence, Singapore has been excluded from this analysis. The main findings are as follows:

(1) A higher level of institutional globalization is not associated with increased economic growth. In fact, Fig. 2.3 indicates a reverse correlation between the two. A closer look at the scattergram, however, reveals that three countries-China, India, and Nigeria - that have attained exceptionally high growth rates despite low levels of institutional globalization have strongly contributed to the reverse correlation. If these three countries are excluded as deviant cases, no correlation is found concerning the level of institutional globalization and economic growth. Global rules enforced by the WTO and other arrangements neither improve nor constrain the economic performance of the emerging states.

(2) At first glance, economic globalization does not seem to be associated with the growth rate. The scattergrams that show relationships between the trade ratio and GDP growth (Fig. 2.4) and between the FDI ratio and GDP growth (Fig. 2.5) demonstrate that no clear-cut relationship exists in each pair. Again, China, India, and Nigeria are the main deviant cases. Their trade ratios and FDI ratios (to GDP) are quite low, but their growth rates are among the highest of the emerging 
GDP Growth Rate (\%)

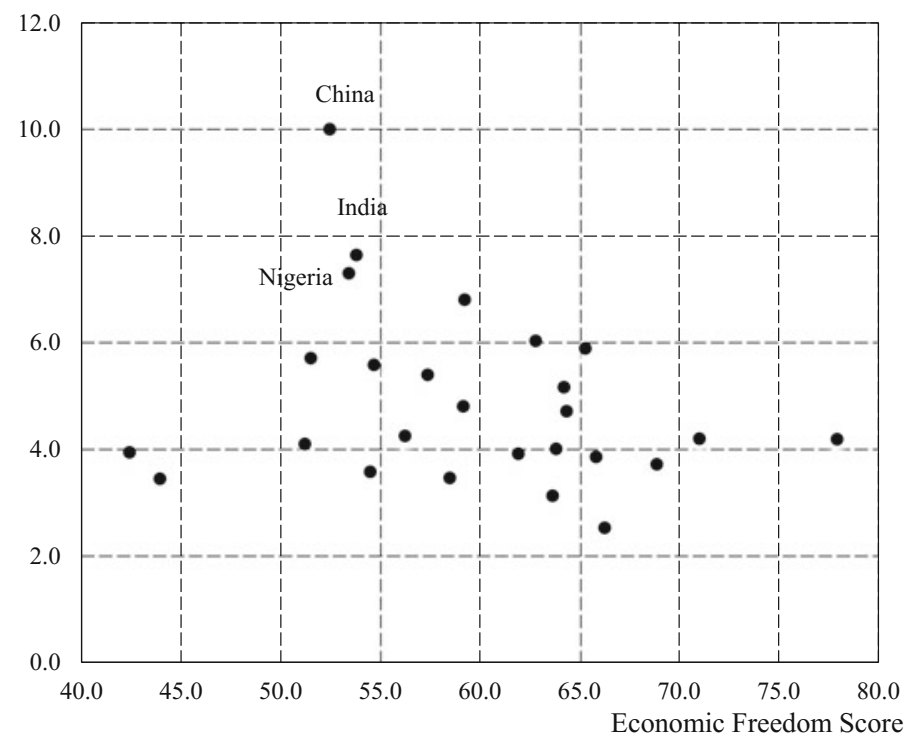

Fig. 2.3 Institutional globalization and growth rates 2003-14 (annual average). Source Appendix 2

states. However, as far as China and India are concerned, this contradiction is superficial to a certain extent. China and India are large countries in economic, geographic, and demographic terms. If the ratio to GDP is calculated, the result should be small simply because the denominator is large, falsely suggesting that their global connections are few. In practice, most of the leading economic sectors in these countries are concentrated in certain geographical areas (such as the coastal regions of China); if this geographical bias is taken into account, China's and India's position in Figs. 2.4 and 2.5 will move in the right-hand direction, strengthening the correlations between the trade ratio and FDI ratio on the one hand and the economic growth rate on the other. Furthermore, calculating China's and India's shares in the total amount of global trade and FDI for the period ranging from 2003 to 2014 reveals that China was at the top in both measures while India was ranked third for trade and sixth for FDI (refer to Appendix 2). It is clear that China and India, in spite of their low levels of institutional globalization, attracted many global traders and investors through whom these countries have strongly participated in and benefited from economic globalization. Nigeria is left as an unexplained case. One possible reason for the exceptionally good economic performance of Nigeria in recent years is that it recovered stability in 1999 after many years of political instability and economic volatility and began a speedy economic recovery based on the rising international price of petroleum. 
GDP Growth Rate (\%)

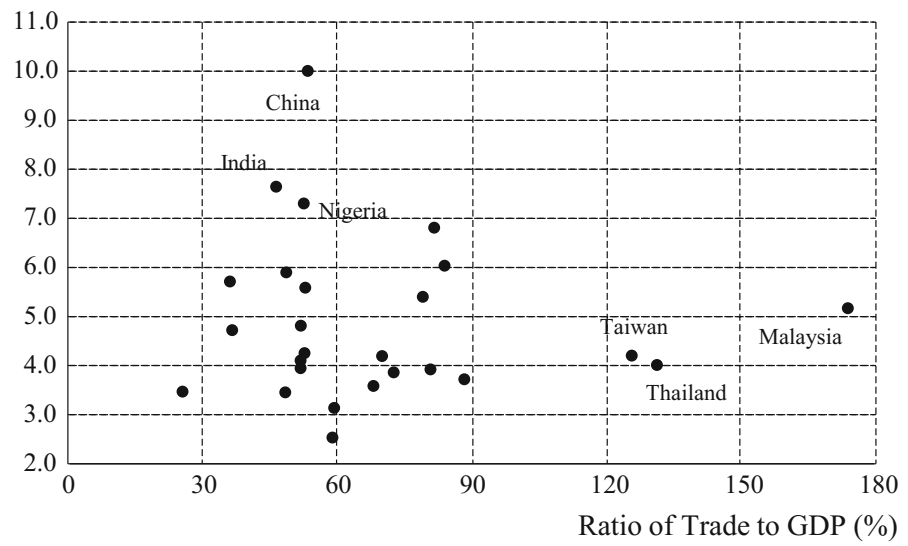

Fig. 2.4 Ratio of trade to GDP and growth rates 2003-14 (annual average). Source Appendix 2

GDP Growth Rate (\%)

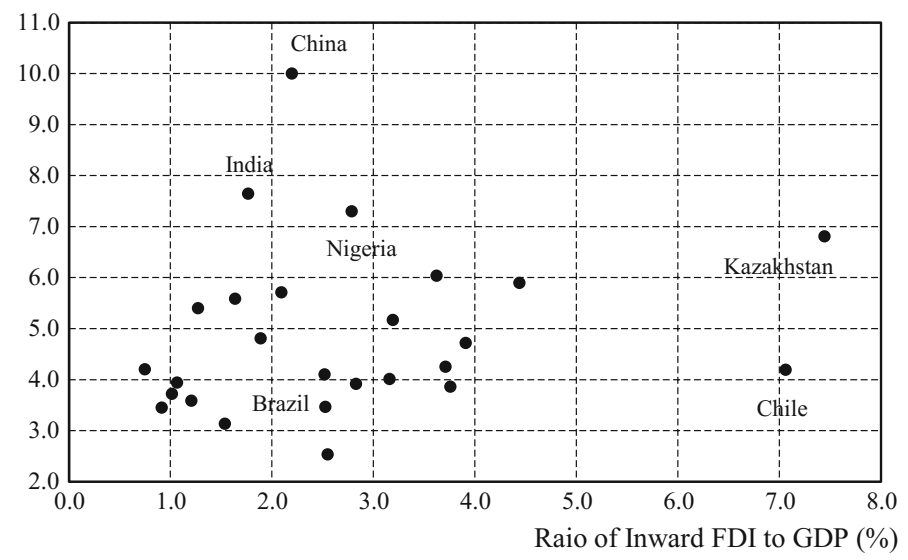

Fig. 2.5 Ratio of inward FDI and growth rates 2003-14 (annual average). Source Appendix 2

(3) The above discussion indicates that there are advantage factors that attract global investors regardless of the extent of an emerging state's institutional globalization. First, the cases of China and India point to the importance of the size of a country's domestic market. Second, the Nigerian case may be indicative of the importance of natural resource endowment. The fact that more than one third of the twenty-eight emerging states depend on natural resources for more than $60 \%$ of their total exports supports this contention. Third, Fig. 2.4 clearly indicates that countries (such as Malaysia, Thailand, and Taiwan) with neither large domestic markets nor high levels of natural resource endowment are highly dependent upon trade. Since a great majority of their exports are manufactured 
goods, it is crucial for these countries to upgrade their technological capability in order to move up in the GPNs and be able to continuously benefit from economic globalization.

Table 2.2 shows how the three advantage factors-domestic market size, natural resources for export, and technological capability-are distributed among the emerging states. Domestic market size is measured by GDP as a percent of US GDP in 2014 (adopted from Appendix 1). Natural resources for export (including fuel, mineral, and agricultural) are measured by their share of total exports in 2006, when the international price of natural resources was rapidly increasing. Technological capability is measured by the net export ratio (NER) of capital goods and parts and components. ${ }^{7}$ Capital goods and parts and components are assumed to be the most complex and technologically sophisticated merchandise. Table 2.2 shows NERs in 2014 and the improvement of NERs between 1995 and 2014.

The emerging states are classified into three groups. The first group is composed of resource-rich countries while the second group covers large-market countries. Russia is included in both. The third group consists of the countries whose domestic market is relatively small and whose share of natural resource exports are not as high as that of the first group of countries. We can discern several interesting patterns in Table 2.2.

(1) The countries that depend heavily on exporting natural resources have small domestic markets except for Russia (and Saudi Arabia to a lesser extent). Their economy is highly vulnerable to the fluctuation of international price of natural resources. The last column of Table 2.2 shows that most of the emerging states experienced declines of GDP growth rate after 2009 when the global recession spread to the whole world but the decline in the resource-dependent countries was especially steep. The record of their NERs is also poor. Although we lack information on the NERs (of capital goods and of parts and components) of many of these countries, we can reasonably assume that their NER is close to zero because their level of manufactured exports is very low. The countries for which we have NER information (Russia, Chile, Peru, and Egypt) experienced either a decline or only minimal improvement of NERs between 1995 and 2014, and their NERs in 2014 were still close to the bottom $(-1.0)$. Natural resource dependence may have a self-reinforcing effect in the sense that resource-dependent countries continue to depend on exporting resources for a long time. The poor performance of Chile may look odd as it is regarded as economically the most successful case in Latin America and is the only country in its region that has attained the status of a high-income country by World Bank standards. The point made by Caldentey (2012) on this matter is illuminating. According to his analysis, Chile has succeeded in developing several "pockets of excellence" in the processing

\footnotetext{
${ }^{7}$ The net export ratio is calculated by dividing the trade surplus of merchandise or a merchandise category by the sum of exports and imports of the same merchandise or merchandise category. It is a rough indicator of the international competitiveness of the merchandise or merchandise category of a certain country.
} 
Table 2.2 Advantage factors of the emerging states

\begin{tabular}{|c|c|c|c|c|c|c|}
\hline & \multirow{2}{*}{$\begin{array}{l}\text { Market } \\
\text { size (GDP } \\
\text { as \% of US } \\
\text { GDP in } \\
2014 \text { ) }\end{array}$} & \multirow{2}{*}{$\begin{array}{l}\text { Natural } \\
\text { resource } \\
\text { export } \\
\text { (share of } \\
\text { total mer- } \\
\text { chandise } \\
\text { export in } \\
2006 \text { ) }\end{array}$} & \multicolumn{2}{|l|}{$\begin{array}{l}\text { Technological } \\
\text { capability }\end{array}$} & \multicolumn{2}{|c|}{ GDP growth rate } \\
\hline & & & $\begin{array}{l}\text { Net export } \\
\text { ratio of } \\
\text { complex } \\
\text { manufactured } \\
\text { goods in } 2014\end{array}$ & \begin{tabular}{|l} 
Improvement \\
of net \\
export ratio \\
between \\
1995 and \\
2014
\end{tabular} & $\begin{array}{l}\text { Annual } \\
\text { average for } \\
\text { 2003-2014 }\end{array}$ & $\begin{array}{l}\text { Percentage } \\
\text { points } \\
\text { difference } \\
\text { between } \\
2003-08 \\
\text { and } \\
2009-14\end{array}$ \\
\hline \multicolumn{7}{|c|}{ Resource-dependent countries } \\
\hline Iraq & 1.1 & 99.6 & Close to -1.0 & Close to 0.0 & 6.7 & -1.6 \\
\hline Algeria & 1.1 & 98.6 & Close to -1.0 & Close to 0.0 & 3.6 & -1.1 \\
\hline Nigeria & 2.8 & 98.6 & Close to -1.0 & Close to 0.0 & 7.3 & -5.5 \\
\hline Venezuela & 2.6 & 94.4 & Close to -1.0 & Close to 0.0 & 3.9 & -7.0 \\
\hline $\begin{array}{l}\text { Saudi } \\
\text { Arabia }\end{array}$ & 4.0 & 91.3 & Close to -1.0 & Close to 0.0 & 6.0 & -2.7 \\
\hline Iran & 2.9 & 85.6 & Close to -1.0 & Close to 0.0 & 3.4 & -4.1 \\
\hline Kazakhstan & 1.1 & 84.7 & Close to -1.0 & Close to 0.0 & 6.8 & -3.5 \\
\hline Russia & 10.4 & 73.7 & -0.8 & -0.24 & 4.1 & -6.1 \\
\hline Chile & 1.6 & 71.5 & -0.88 & 0.04 & 4.2 & -1.1 \\
\hline Peru & 1.1 & 68.3 & -0.92 & 0.05 & 5.9 & -1.7 \\
\hline Egypt & 1.5 & 60.2 & -0.9 & -3.2 & 4.3 & -2.4 \\
\hline \multicolumn{7}{|c|}{ Large-market countries } \\
\hline China & 50.9 & 4.5 & 0.32 & 0.39 & 10.0 & -2.7 \\
\hline Brazil & 14.9 & 22.2 & -0.47 & -0.09 & 3.5 & -1.5 \\
\hline India & 13.6 & 24.1 & -0.38 & 0.15 & 7.6 & -0.3 \\
\hline Russia & 10.4 & 73.7 & -0.8 & -0.24 & 4.1 & -6.1 \\
\hline $\begin{array}{l}\text { South } \\
\text { Korea }\end{array}$ & 7.6 & 9.6 & 0.35 & 0.39 & 3.7 & -1.0 \\
\hline Mexico & 7.3 & 18.3 & 0.00 & 0.00 & 2.5 & -1.0 \\
\hline \multicolumn{7}{|c|}{ Other countries } \\
\hline Philippines & 1.6 & 7.3 & 0.31 & 0.30 & 5.4 & 0.0 \\
\hline Taiwan & 3.1 & n.a. & 0.30 & 0.15 & 4.2 & -0.7 \\
\hline Malaysia & 1.9 & 17.9 & 0.20 & 0.24 & 5.2 & -1.2 \\
\hline Thailand & 2.4 & 11.5 & 0.10 & 0.37 & 4.0 & -1.9 \\
\hline
\end{tabular}


Table 2.2 (continued)

\begin{tabular}{|c|c|c|c|c|c|c|}
\hline & \multirow{2}{*}{$\begin{array}{l}\text { Market } \\
\text { size (GDP } \\
\text { as \% of US } \\
\text { GDP in } \\
2014)\end{array}$} & \multirow{2}{*}{$\begin{array}{l}\text { Natural } \\
\text { resource } \\
\text { export } \\
\text { (share of } \\
\text { total mer- } \\
\text { chandise } \\
\text { export in } \\
2006 \text { ) }\end{array}$} & \multicolumn{2}{|l|}{$\begin{array}{l}\text { Technological } \\
\text { capability }\end{array}$} & \multicolumn{2}{|c|}{ GDP growth rate } \\
\hline & & & $\begin{array}{l}\text { Net export } \\
\text { ratio of } \\
\text { complex } \\
\text { manufactured } \\
\text { goods in } 2014\end{array}$ & $\begin{array}{l}\text { Improvement } \\
\text { of net } \\
\text { export ratio } \\
\text { between } \\
1995 \text { and } \\
2014\end{array}$ & $\begin{array}{l}\text { Annual } \\
\text { average for } \\
2003-2014\end{array}$ & $\begin{array}{l}\text { Percentage } \\
\text { points } \\
\text { difference } \\
\text { between } \\
2003-08 \\
\text { and } \\
2009-14\end{array}$ \\
\hline Poland & 3.3 & 10.7 & -0.04 & 0.42 & 3.9 & -2.0 \\
\hline Singapore & 1.7 & 14.6 & -0.18 & 0.55 & 6.1 & -1.5 \\
\hline Turkey & 5.4 & 8.0 & -0.33 & 0.43 & 4.8 & -2.1 \\
\hline Indonesia & 5.8 & 43.6 & -0.36 & 0.25 & 5.6 & 0.0 \\
\hline $\begin{array}{l}\text { South } \\
\text { Africa }\end{array}$ & 2.5 & 39.7 & -0.37 & 0.00 & 3.1 & -2.7 \\
\hline Argentina & 2.8 & 21.0 & -0.5 & 0.08 & 5.7 & -4.1 \\
\hline Colombia & 2.2 & 46.8 & -0.9 & 0.00 & 4.7 & -0.9 \\
\hline Pakistan & 1.3 & 6.8 & n.a. & n.a. & 4.4 & -2.1 \\
\hline
\end{tabular}

Sources Market size, Natural resource export, and GDP growth rate come from own calculation based on data derived from World Development Indicator database and IMF's Economic Outlook database; Net export ratio comes from own calculation based on data derived from RIETI's Trade Industry Database 2014. http://www.rieti-tid.com/. Accessed 25 November 2016

industries of wine, salmon, wood, and fruit, but their spillover effect in the domestic economy is low.

(2) The large domestic market countries can be divided into two groups. China, South Korea, and India succeeded in improving their NERs substantially between 1995 and 2014, and China and South Korea came to have positive NERs by 2014. Brazil, Russia, and Mexico, in contrast, experienced either a decline or zero improvement in NERs between 1995 and 2014; furthermore, their NERs in 2014 were either negative or zero. To grow economically in the global market, the former three countries are making efforts to improve the technological capability of their industries without solely depending on their large-market advantage. The latter group is weak in the area of technological upgrading.

(3) The countries in the third group have small domestic markets (except for the relatively large markets of Turkey and Indonesia). Their dependence on resource exportation is also much smaller than the first-group countries. What is char- 
acteristic of the third-group countries is the substantial improvement of their technological capability. All the countries except for South Africa and two Latin American countries (Argentina and Colombia) improved their NERs to a great extent between the years of 1995 and 2014, suggesting that their success largely depended on upgrading their technological capability which helped deepen their participation in the GPNs. It should also be noted that the expansion of regional (intra-Asian) trade and investment in the manufacturing industries has helped the Asian emerging states to form regional division-of-labor networks in which they upgraded their respective industrial structure and stepped up the value chains jointly, a pathway which is limited to a minimum in Latin America and Africa.

In conclusion, low levels of institutional globalization have not imposed insurmountable constraints on emerging states' ability to more deeply participate in economic globalization and to benefit from it in terms of achieving high rates of economic growth. This is because they have certain advantage factors such as large domestic markets, abundant natural resources for export, and appropriate technological capabilities that are attractive to global traders/investors regardless of the degree of institutional globalization of each emerging state. Every emerging state has at least one of the three advantage factors. All of these results demonstrate that the alarmist view does not fit the experience of emerging states as far as economic growth is concerned. However, endorsing the optimistic view is premature because economies that are excessively dependent on exporting natural resources are vulnerable to volatility in the international prices of commodities. It is also not easy for emerging states to compete with each other to keep up with the speed of technological upgrading demanded by the GPNs. I will return to this subject in Sect. 2.6, which deals with the future prospects of the emerging states.

\subsubsection{Social Policy and Income Distribution}

One of the most serious concerns about globalization is its presumed negative impact on national policymaking autonomy and the resultant deterioration of social welfare and protection. Unfortunately, it is more difficult to obtain social data (as opposed to economic data) that is comparable across many countries. In addition, different countries use different definitions of social welfare and protection. Here, I am compelled to look only at Asia and Latin America and to rely on separate datasets for each region.

Tables 2.3 and 2.4 show the share (in GDP) of public spending on social insurance and assistance (or welfare) in six Latin American countries and nine Asian countries respectively. In all five Latin American countries with data available for the period of 1991-2002, the annual average share of social spending improved between the first period (1991-1994) and the second (1999-2002). The nineteen-nineties was the decade in which these countries implemented reforms oriented toward institutional 
Table 2.3 Public expenditures for social insurance and social assistance (share of GDP, annual average)

\begin{tabular}{l|l|l|l}
\hline & $1991-94$ & $1999-2002$ & $2009-2012$ \\
\hline Argentina & 8.4 & 8.5 & 10.4 \\
\hline Brazil & 9.6 & 11.3 & 12.8 \\
\hline Chile & 7.2 & 7.5 & 6.6 \\
\hline Colombia & 2.6 & 4.4 & 7.7 \\
\hline Mexico & 0.4 & 2.2 & 3.1 \\
\hline Peru & n.a. & 4.1 & 3.3 \\
\hline
\end{tabular}

Source CEPAL (2016)

Table 2.4 Central government expenditure for social insurance and welfare (share of GDP, annual average)

\begin{tabular}{l|l|l|l}
\hline & $1991-95$ & $2000-2004$ & $2010-2014$ \\
\hline China & 0.2 & 1.2 & 2.4 \\
\hline India & n.a. & 0.8 & $0.5(2010-13)$ \\
\hline South Korea & 1.1 & 2.9 & 4.8 \\
\hline Taiwan & 3.4 & 4.0 & 3.4 \\
\hline Malaysia & 0.9 & 1.2 & 1.0 \\
\hline Thailand & 0.5 & 1.6 & 1.9 \\
\hline Philippines & 0.3 & 0.8 & 1.2 \\
\hline Indonesia & $0.9(1994-95)$ & $1.3(2001-04)$ & n.a. \\
\hline Singapore & $0.8(1995)$ & $0.6(2000)$ & $1.5(2011-14)$ \\
\hline
\end{tabular}

Note GDP of all the countries except for India is for calendar year. Government expenditure is also for calendar year for all the countries except for Taiwan (up to 2000), Thailand, and Singapore. Government expenditure of these countries and India is for fiscal year. Definition of "social insurance and welfare" differs from one country to another. Source ADB $(2010,2016)$

globalization, such as fiscal balance, privatization, trade and investment liberalization, and increased flexibility within the labor market in exchange for debt relief arranged by the IMF and the US government. As a result of these reforms, labor conditions generally deteriorated, although the degree of deterioration diverged according to the power and structure of labor unions (Teichman 2001; Murillo 2001). Contradicting the alarmist view, Table 2.3 shows that Latin American governments responded to social dislocations during a period of rapid globalization by increasing the share (if not the absolute amount) of social spending.

Table 2.4 indicates that the pattern of change in social spending in Asia is similar to that of Latin America between the first period (1991-1995) and the second (2000-2004), although the GDP share of social spending was much smaller in Asia. The social welfare system in the Asian countries has been described as "productive welfare capitalism" (Holliday 2000; Kim 2016), the "developmental welfare state" (Kwon 2002), or the "Listian workfare national state" (Jessop 2016). These authors share the view that people's welfare was secured not so much by the welfare state 
as by the increase in employment opportunities that the government helped create by fostering labor-intensive industries and by enhancing educational opportunities. Social policy was thus subordinate to economic policy. Even so, Asian governments needed to increase social spending to cope with the social dislocations caused by the AFC and post-AFC market reforms (institutional globalization). The countries that experienced a democratic transition between the late 1980s and the late 1990s (such as South Korea, the Philippines, Thailand, Taiwan, and Indonesia) were also exposed to greater pressure from their electorates to increase social provisions for healthcare, pensions, and social assistance. ${ }^{8}$ Singapore provides a notably exceptional case that substantiates the alarmist view that globalization brings deterioration of social welfare. Singapore is the most globalized of the emerging countries, scoring highest on the Economic Freedom Score and trade and FDI ratios to GDP among the emerging states; differing from other Asian countries, it responded to the AFC by reducing social spending. It also reduced firms' obligatory contributions to the Central Provident Fund (the national fund composed of individual accounts that are used for healthcare, pensions, and other individual expenses) (Kim 2016, pp. 113-14).

During the following decade, four Latin American countries and five Asian countries (including Singapore) increased their share of GDP dedicated to social spending. Chile, Peru, India, Taiwan, and Malaysia are in the minority of countries that reduced their social spending share. Together, Tables 2.3 and 2.4 show that the emerging states in Asia and Latin America could generally expand their social spending in the face of social dislocations caused by economic crises and greater exposure to globalization. However, whether such fiscal expansion contributed to a decline in social disparity is a separate question.

Figures 2.6 and 2.7 provide information on changes in income distribution in Latin America and Asia during the period of 1989-2013. Fig 2.6 reveals a seeming contradiction concerning the effect of social spending in Latin America. In three of the seven Latin American countries (Argentina, Colombia, and Venezuela), income distribution deteriorated between the first period (1989-1991) and the third period (2001-2003). In addition, Mexico experienced a slight deterioration in income distribution between the first period (1989-1991) and the second period (1995-1997). A similar deterioration was observed in Peru from the second period (1995-1997) to the third (2001-2003). As we saw above, these were the periods during which the share of social spending increased in those countries.

In contrast, after the period of 2001-2003, income distribution improved in all the countries, including Chile and Peru that reduced their share of GDP devoted to social spending.

One explanation for this seeming contradiction between changes in social spending and changes in income distribution in Latin America is the enormous social dislocations that the debt crisis and hyperinflation (of a magnitude of three to four

\footnotetext{
${ }^{8}$ Both Ramesh (2003) and Kim (2016) stress the importance of electoral competition in the expansion of welfare programs in South Korea and Taiwan. The universal health care program introduced in 2001 by Thaksin Sinawatra, then prime minister of Thailand, is another example of electoral-populist policy.
} 


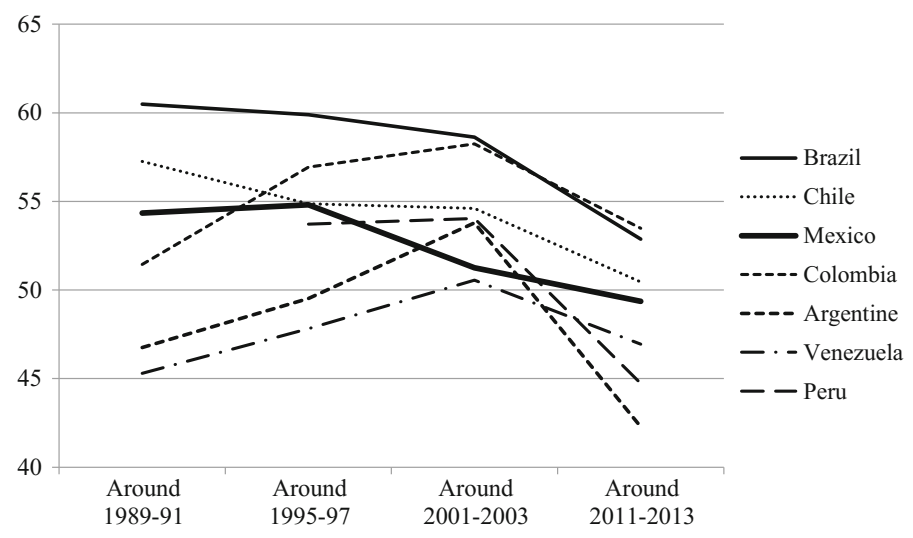

Fig. 2.6 GINI index in Latin American countries (distribution of income). Source World Bank's PovcalNet database. http://iresearch.worldbank.org/PovcalNet/povOnDemand.aspx. Accessed 3 December 2016

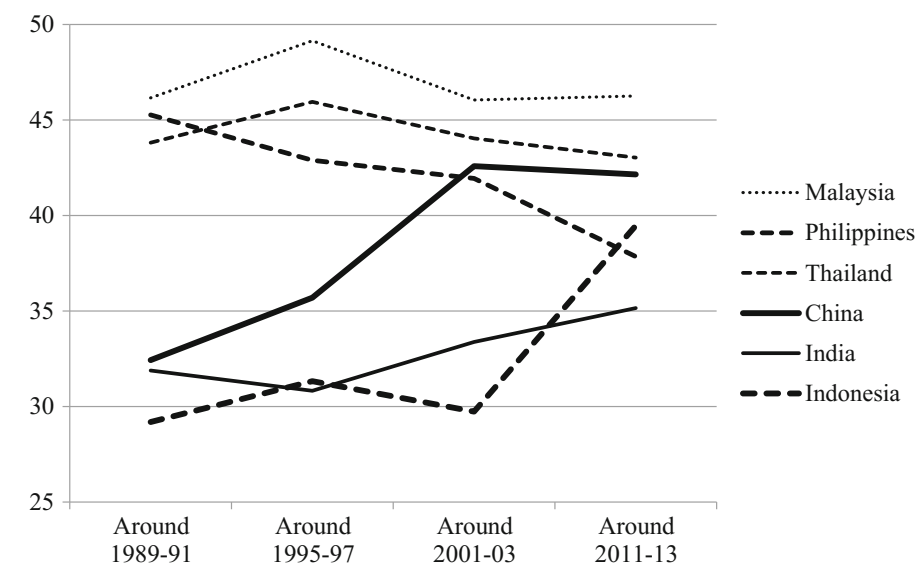

Fig. 2.7 GINI index in Asian countries (distribution of income or consumption expenditure). Note Figure for Malaysia is distribution of income. All others are distribution of consumption expenditure. Source World Bank's PovcalNet database. http://iresearch.worldbank.org/PovcalNet/ povOnDemand.aspx. Accessed 3 December 2016

digits) incurred in the region during the 1980s and the first half of the 1990s. Such social dislocations were so serious that even a substantial increase in social spending during the 1990s could not compensate for the damages. Social spending started to have some effects only in the 2000s when economic conditions were normalized. In addition, many Latin American countries introduced conditional cash transfer (CCT) programs during the 2000s. As these programs attempted to focus on the poorest segments of the population, they may have contributed to the improvement of income distribution. As of 2010, the number of beneficiaries of these programs 
reached 29\% (Argentina), 27\% (Brazil), 25\% (Colombia), and 24\% (Mexico) of the country's total populations (Stampini and Tornarolli 2012, p. 10).

The important role of social spending notwithstanding, many studies on income distribution in Latin America point out that a large part of the improvement in income distribution during the 2000s is explained by economic growth rather than by income redistribution. For instance, Stampini and Tornarolli (2012, p. 12) indicate that it was economic growth that contributed to reducing the number of poor households. The reduction was so rapid that CCT became less redistributive as families whose income had been improved continued to receive the benefits. A World Bank study team found that a rapid and sizable increase in upward mobility, from the low-income to the middle-income strata, occurred after 2003 and that $74 \%$ of the increase in the number of middle-income families (those with \$10-50 USD of income per day) can be explained by the increase in per capita income. The rest is attributable to income redistribution (Ferreira et al. 2013, pp. 3-4). Birdsall (2014, p. 264) reached the same conclusion concerning Brazil. Also discussing Brazil, Power (2016, p. 214) attributed $54.9 \%$ of the disparity shrinkage to the improvement in labor remuneration and only $12.2 \%$ to Bolsa Familia (Brazil's CCT program).

The pattern of change in income distribution in Asia is quite different from that in Latin America. As shown in Fig. 2.7, the increase in the social spending share of GDP is generally more closely associated with the improvement of income distribution in Asia. Between the second period (1995-1997) and the third (2001-2003), Malaysia, Thailand, and Indonesia, which were most heavily hit by the AFC, ${ }^{9}$ enhanced their social spending and also saw an improvement in income distribution. After 2003, Malaysia and India reduced their share of GDP devoted to social spending, and their income distribution deteriorated, while China, Thailand, and the Philippines experienced both increased social spending and improvement in income distribution.

Furthermore, high economic growths in the Asian countries contributed to general improvement of poor people's life. However, different from the Latin American pattern, high growth rates did not necessarily guarantee a reduction in income disparity in Asia, as shown by the experiences of India and China between the second period (1995-1997) and the third (2001-2003), and the experiences of India, Malaysia, and Indonesia between the third period (2001-2003) and the fourth (2011-2013). In these countries, the growth of globally integrated sectors and regions has been so speedy that other sectors and regions are left behind.

In conclusion, as in the case of economic growth, neither the alarmist nor the optimistic view of globalization could explain the pattern of social spending and income distribution in Asia and Latin America. Most of the emerging states in Asia and Latin America expanded social-spending shares to cope with shocks caused by economic crises and subsequent market reforms promoting institutional globalization. ${ }^{10}$

\footnotetext{
${ }^{9}$ South Korea is another victim of the AFC but is not mentioned here due to the absence of comparable data.

${ }^{10}$ A study by a World Bank group demonstrated that poverty-oriented universal health care programs enhanced coverage between 2006 and 2011 not only in Asia and Latin American but also in countries such as Nigeria, South Africa, and Turkey (Cotlear et al. 2015, Table 1.1).
} 
Economic globalization helped the Asian and Latin American countries attain high rates of economic growth, which in turn contributed to reducing income disparity. However, contradicting the optimistic view, there are cases in which social spending was not enough to compensate for the social dislocations caused by economic shocks and institutional globalization or by regionally and sectorally imbalanced growth. Neither is steady economic growth (that will contribute to reducing income disparity) guaranteed. As discussed in the previous subsection, continuous economic growth largely depends on the future availability of the advantage factors that each emerging state can offer.

\subsubsection{Globalization and Political Transformation}

As Rodrik's trilemma argument indicates, the pessimist view of globalization insists that it is incompatible with democracy while the more cautious view endorsed by Acemoglu and Robinson admits the possibility that globalization facilitates democratization under certain conditions.

Many of the works dealing with democratization in the post-Cold War era indicate that the post-Cold War euphoria of "third wave" democratization (Huntington 1991) receded by the early 2000s; Larry Diamond observed that "the trend toward democracy has been accompanied by an even more dramatic trend toward pseudodemocracy" (Diamond 2002, p. 27). Authors use slightly different definitions of "pseudodemocracy," but they share the view that, in contrast to outright autocracy, pseudodemocratic (or hybrid, competitive authoritarian, or electoral authoritarian) regimes adopt many conventional democratic institutions, especially multi-party elections. In many cases, semi-authoritarian regimes manage these institutions in ways that are highly disadvantageous to the opposition, although elections can work against authoritarian continuity under certain conditions (Brownlee 2007; Levitsky and Way 2010; Schedler 2013). These observations indicate that neither the transition to democracy nor to autocracy has been a dominant pattern during the period of hyper-globalization.

Table 2.5, which categorizes emerging states by their regime types during the periods of 1991-1993 and 2013-2015, substantiate this contention. Twenty-one out of the twenty-eight emerging states $(72 \%)$ had the same kind of political regime during the 2013-2015 period that they had during the 1991-1993 period, while the remaining eight states shifted from "partly free" regimes to "free" or "not free" regimes in equal number (four for each). There was no general tendency toward authoritarian resurgence or toward democratic transition as far as the emerging states were concerned. This observation supports the cautious view that the political-regime impact of globalization is not monotonic.

Table 2.5 also shows that the relative degree of globalization is not associated with specific regime or regime change. "I" in the parentheses indicate that the score of institutional globalization of that country was higher than the median of the scores of all 28 emerging states. "E" means relatively high economic globalization (trade 
Table 2.5 Political regime in 1991-1993 and 2013-2015

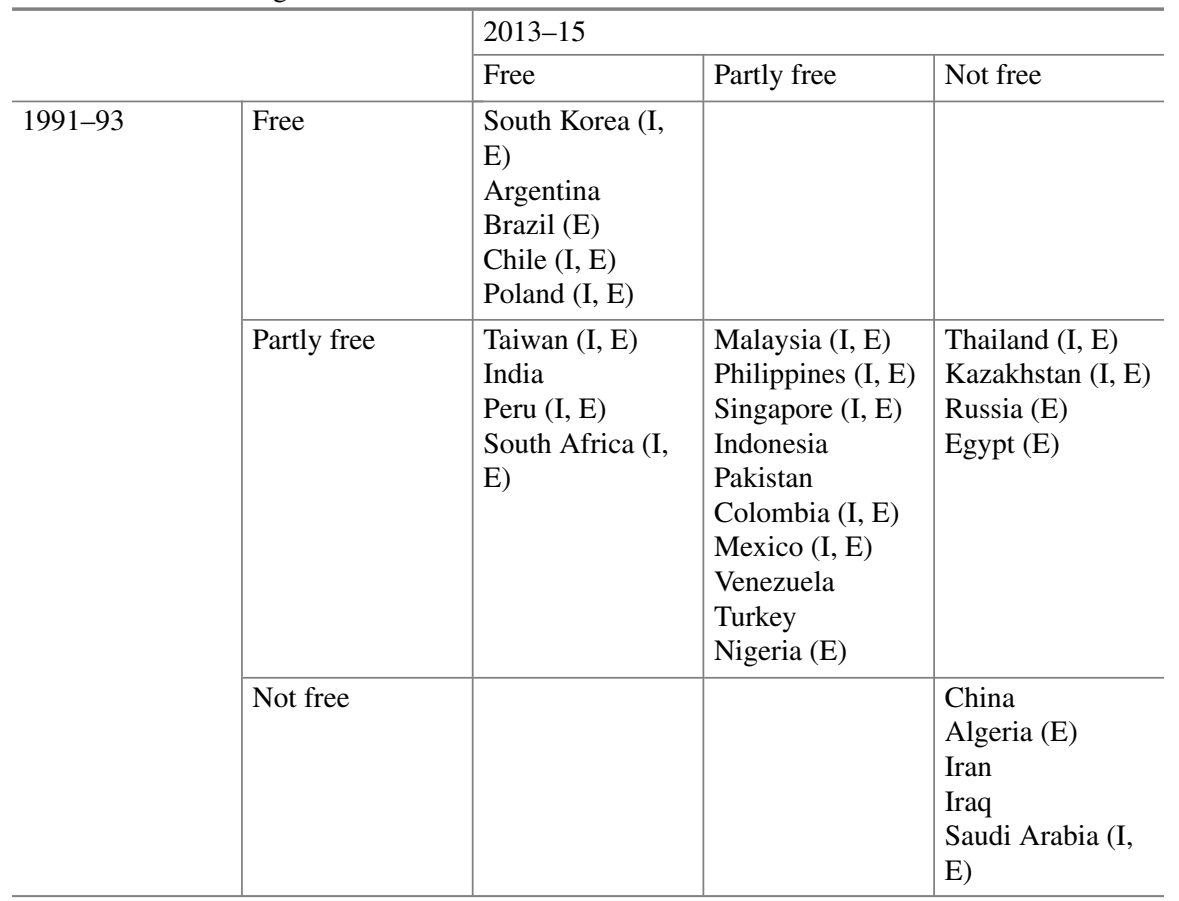

Source Freedom House "Freedom in the World Country Ratings," accessed 11 August 2015; Appendix 2

share and/or FDI share). The countries which were "not free" in both 1991-1993 and 2013-2015 tend to record relatively low institutional and economic globalization. Beside this tendency, Table 2.5 demonstrates that the relatively high globalization does not necessarily favors specific political regime or regime transformation.

\subsection{Institutions and Economic and Social Performance}

The above examination of economic, social, and political impacts of globalization shows that the cautious view best grasps what has actually happened in the emerging states. Globalization does not always foster or impede economic growth. It depends on the nature of advantage factors that each emerging state can offer to the global economy. Neither does globalization always bring the enhancement or shrinkage of social equity. It depends on deepness of economic crises, sustainability of economic growth, and the degree of imbalanced development in different localities and sectors. Finally, globalization does not necessarily foster democracy or autocracy. The cautious view of globalization, as I discussed in Sect. 2.3.1, emphasizes the impor- 
tance of political and institutional arrangements to explain the differing economic performance of national states. This is because sustained economic growth in the context of globalization requires the coordination of interests among big (foreign and domestic) firms, small producers, and workers in order to deepen and broaden domestic linkages for technological upgrading. The similar interest coordination will be needed to cope with the major concern of the alarmist view of globalization- the loss of social cohesion due to the enhancing gap between globally integrated and benefited segments of the population and those who are left behind with little connection to globalized networks and benefits. To alleviate this social disparity, tradable sectors and higher income people must bear the tax burden generated by redistributive measures.

The questions are best stated as follows: Under which political order (or institutional complex) can this type of coordination be optimally achieved, and how can such order be formed and maintained politically? Many studies seem to indicate that successful coordination depends on a political order in which the state is not easily subject to pressure from special interest groups or rent-seeking individuals but at the same time is close enough to the private sector for consultation and cooperation. For instance, Doner et al. (2005, p. 328) argue that to successfully cope with coordination and other problems relating to upgrading, a country needs "organizational complexes in which experts and coherent bureaucratic agencies collaborate with organized private sectors to spur national economic transformation." In this regard, South Korea, Taiwan, and Singapore are superior to Malaysia, Thailand, Indonesia, and the Philippines. This argument is an extension of earlier work on "embedded autonomy" (Evans 1995) and "governed interdependence" (Weiss and Hobson 1995; Weiss 1998). Coinciding with Macintyre (2003), who examined the divergent responses of Southeast Asian countries to the AFC, Doner believes that under the optimal institutional arrangement, the number of veto players (i.e., influential actors in policymaking) is neither too large nor too small. Having too many veto players facilitates free-riding and consequently makes consensus-building difficult. Too small a number of veto players will heighten the fear of arbitrary policy changes and therefore lower the credibility of lasting commitment by top political leaders. Neither is good for the coordination of those involved in technological upgrading (Doner 2009, pp. 92-93).

\subsubsection{Political Regime as a Macro-Political Institution}

To examine the coordinating functions of different political and institutional arrangements, I first focus on political regime as a macro-political institution. The number of veto players is usually smaller in the authoritarian regimes than in the democratic regime. However, we can generally expect that the optimal political order in which veto players are neither too many nor too few are found most frequently in regimes that fall between the democratic and the authoritarian ends of the political order spectrum. In Table 2.5, "partly free" regimes are such intermediate regimes. 
Table 2.6 Political regime and improvement in income distribution

\begin{tabular}{|c|c|c|c|c|}
\hline & & \multicolumn{3}{|l|}{ 2001-03 } \\
\hline & & Free & Partly free & Not free \\
\hline \multirow[t]{3}{*}{ 1989-91 } & Free & $\begin{array}{l}\text { Brazil } \\
\text { Chile } \\
\text { India } \\
\text { Thailand }\end{array}$ & $\begin{array}{l}\text { Argentina } \\
\text { Venezuela }\end{array}$ & \\
\hline & Partly free & $\begin{array}{l}\text { Mexico } \\
\text { Peru } \\
\text { Philippines }\end{array}$ & $\begin{array}{l}\text { Colombia } \\
\text { Indonesia } \\
\text { Malaysia }\end{array}$ & \\
\hline & Not free & & & China \\
\hline & & \multicolumn{3}{|l|}{ 2011-13 } \\
\hline & & Free & Partly free & Not free \\
\hline \multirow[t]{3}{*}{$2001-03$} & Free & $\begin{array}{l}\text { Brazil } \\
\text { Chile } \\
\text { India } \\
\text { Peru }\end{array}$ & $\begin{array}{l}\text { Mexico } \\
\text { Philippines } \\
\text { Thailand }\end{array}$ & \\
\hline & Partly free & $\begin{array}{l}\text { Argentina } \\
\text { Indonesia }\end{array}$ & $\begin{array}{l}\text { Colombia } \\
\text { Malaysia } \\
\text { Venezuela }\end{array}$ & \\
\hline & Not free & & & China \\
\hline
\end{tabular}

Note The countries in bold letters are those that recorded the improvement of income distribution. Sources Freedom House "Freedom in the World Country Ratings" (accessed 11 August 2015) and Figs. 2.6 and 2.7 in this chapter

It is true that the largest number of the emerging states is concentrated in the category in which the regimes were "partly free" in both 1991-1993 and 2013-2015. However, If the numbers of the emerging states that had either democratic or authoritarian regimes in the two periods are counted together, they are as numerous as the consistently "partly free" countries. In addition, the equal number of countries changed their regime from "partly free" to "free" or "not free" between 1991-1993 and 2013-2015. The nature of political regime does not seem to be associated with the economic performance of the emerging states.

As for social performance, since we have only limited data on income distribution, it is difficult to find clear patterns. In Table 2.6, the names of the countries that saw significant improvement in income distribution appear in bold. During the periods of 1989-1991 and 2001-2003, the countries that remained "free" or became freer (Brazil, Chile, Mexico, and the Philippines) showed improvement in social performance. However, such a tendency ceased to be observed after the period of 2001-2003, in which most of the "free" and "partly free" countries equally experienced social improvement.

In short, we cannot conclude that semi-authoritarian regimes have achieved superior economic and social performances. We must investigate institutional variations among countries with the same regime types. For instance, writing from a historical point of view, Slater (2010) compared the "ordering power" of Southeast Asian states. 
He argued that their ordering power diverges because different relations between the state and the elites developed due to divergent experiences of class and/or communal conflict during the early post-colonial era. In countries such as Malaysia and Singapore, elites (state officials, economic elites, middle class, communal leaders) needed protection from the state in the face of endemic and unmanageable internal threats. As a result, a strong and durable regime capable of extracting resources even from its elite members as the need arose was formed. In contrast, the state leaders of the Philippines, Thailand, and South Vietnam needed to provide wasteful patronage benefits to secure the support of the elites, as these elites did not face serious mass mobilization and were fragmented among themselves. Consequently, the political regime in the latter group of countries became fragile both politically and economically. From a more functional point of view, Macintyre (2003) attempts to explain divergent veto-player distributions by examining factors such as the number of political parties, their internal cohesiveness, and executive-legislative relations. Rock (2013) distinguishes majoritarian institutions from proportional institutions. Even concerning the highly authoritarian China, Breznitz and Murphree (2011, Chap. 1) use the term "structural uncertainty" to indicate the institutional complexity that leaves reform policies ambiguous; this allows multiple interpretations that accommodate various policy players in the central government, local governments, and the Communist Party.

\subsubsection{Bureaucracy as a Micro-Level Institution}

Examining the variations in micro-level institutions in the emerging states is a necessary but daunting task. In this chapter, I will only examine the nature of the state bureaucracy. This is because almost all literature concerning the role of the state in development regards the insulation of the governing body from special social interests as an essential element of good performance. "Embeddedness" with market and society is another important element for success. However, it is difficult to measure the degree of "embeddedness." In contrast, Evans and Rauch (1999) provide unique and useful data on "Weberianness" of the economic bureaucracy. They measure the nature of the bureaucracy by their organizational features. They especially emphasize two factors: meritocratic recruitment and promotion and a predictable career ladder which provides long-term tangible and intangible rewards. These structural features will contribute to the development of competent, purposive, and cohesive bureaucracy with a long-term perspective. It is expected that such bureaucracy will be less susceptible to the private capture and value public purposes.

Evans and Rauch (1999) provide "Weberianness scale scores" for 35 developing countries, out of which 18 are the emerging states. Table 2.7 shows the nature of political regime and "Weberianness" of the bureaucracy in these countries in the late 1990s. The figures in parentheses indicate the growth rate between 1990 and 2014 adopted from Appendix 1. The sample is too small to have any conclusive observation, but "Weberianness" seems to explain differential growth rates better 
Table 2.7 Political regime, Weberianness of bureaucracy, and economic growth

\begin{tabular}{l|l|l|l|l}
\hline \multicolumn{2}{l}{} & \multicolumn{3}{|l}{ Weberianness of bureaucracy (late 1990s) } \\
\cline { 3 - 5 } \multicolumn{2}{c|}{} & High & Medium & Low \\
\hline $\begin{array}{l}\text { Political regime } \\
\text { (1998-2000) }\end{array}$ & Free & $\begin{array}{l}\text { India (352) } \\
\text { South Korea } \\
(227)\end{array}$ & & $\begin{array}{l}\text { Argentina (129) } \\
\text { Chile (221) } \\
\text { Philippines (165) } \\
\text { Taiwan (231) }\end{array}$ \\
\cline { 2 - 5 } & Partly free & $\begin{array}{l}\text { Malaysia (284) } \\
\text { Singapore (316) }\end{array}$ & $\begin{array}{l}\text { Brazil (103) } \\
\text { Colombia (135) } \\
\text { Mexico (90) } \\
\text { Thailand (170) } \\
\text { Turkey (149) }\end{array}$ & $\begin{array}{l}\text { Nigeria (245) } \\
\text { Peru (209) }\end{array}$ \\
\cline { 2 - 5 } & Not free & Pakistan (158) & Egypt (165) & \\
\hline
\end{tabular}

Note When the Weberian scale score of a country exceeds ten, the country is categorized as a "high" Weberianness state while it is categorized as a "low" Weberianness state when the score is smaller than six. Sources Weberianness of bureaucracy is from Evans and Rauch (1999), Appendix C; Political regime is from Freedom House database

than the nature of political regimes. The emerging states with high "Weberianness" recorded higher growth rates than the countries with medium or low "Weberianness" except for Pakistan and Nigeria. Pakistan is "high" in terms of Weberian structure of its bureaucracy but economic performance is low. Nigeria recorded a high economic growth in spite of low Weberianness of its bureaucracy. However, it should be recalled that Nigeria, together with Chile and Peru in Table 2.7, is a country highly dependent of natural resource exports. Economic growth of resource-rich countries may not need a professional bureaucracy as long as the international price of resources is high.

Beside the nature of bureaucracy, we can think of many other micro- or meso-level institutions that may affect the capability of individual national states to respond to opportunities and risks of globalization. Mechanisms linking the public and private sectors, relationship between the executive and legislative branches of a government, and the electoral and party system are some of such institutions. The examination of these institutions, however, cannot be taken up in this study. Such attempt must await another research opportunity.

\subsection{Future of the Emerging States}

\subsubsection{Modes of Global Integration}

As discussed in Sect. 2.4.1, emerging states have achieved strong economic performances by participating in and benefiting from economic globalization. To do so, they offered various advantage factors to global actors, such as natural resources, 
large domestic markets, and appropriate technological capabilities. The question to be asked is whether emerging states will be able to maintain or improve their current rate of catching-up by relying on their current advantage factors.

The exportation of natural resources seems to be the least promising path. For one thing, excessive dependence on the exportation of natural resources is risky and unsustainable, as the international price of natural resources is notoriously unstable. One way out of this impasse involves building and strengthening downstream processing industries. The oil palm industry and the rubber industry in Malaysia, and the food processing industries in Thailand, are successful cases in this respect (Rasiah 2006; Oikawa 2015; Kawano 2017; Suehiro 2017; Intarakumnerd 2017). However, as the case of Chile shows, the development of resource processing industries may face limitations unless the benefits of their development spill over into more technologically advanced sectors.

Countries like China and India are at an advantage based on the mere size of their domestic markets. To gain access to such large markets, global economic players will continue to cajole these countries into the economic globalization process regardless of their poor record of institutional globalization. However, it should be noted that not all large-market countries have a high growth rate. For instance, China and Brazil share a similar FDI-to-GDP ratio (Fig. 2.5), but the growth rates of these two countries are spectacularly different. Table 2.2 clearly indicates that high-growth large-market countries (China, India, and South Korea) have made far greater efforts in upgrading the technological capability of their industries. In contrast, the technological capabilities of Brazil, Russia, and Mexico deteriorated or showed no improvement between 1995 and 2014. Schneider (2013, pp. 170-71) wrote that Brazilian private firms (with the exception of certain natural resource companies) have low levels of funding for their R\&D activities despite various promotional policies of the government. In contrast, according to Sihna (2016), who analyzed the pharmaceutical and textile industries in India, the private sector of that country, confronted with pressing WTO obligations, changed its strategy from sheltering under government protection to seeking to promote exports and international competitiveness. As a consequence, these industries increased their R\&D expenditures and extended backward and forward linkages of production. On the other hand, in their analysis of the electronics and ICT industries in China, Breznitz and Murphree (2011, p.3) point out that "China can excel in a wide array of innovative activities that might not advance the technological frontier but can certainly transform how the global economy works."

The countries that have neither a large domestic market nor an abundant resource endowment will need to be continuously integrated into the GPNs as exporters of manufactured goods and providers of business support services. Although there are cases in which technological "catch-down" (or downgrade) for specific domestic markets results in greater value capture (Coe and Yeung 2015, p. 173), it will be indispensable in the long run for emerging states to upgrade their technological capability if they want to maintain or improve their status in the GPN. As Yusuf (2004, p. 6) pointedly argues, these countries' competitiveness is "predicated on technological deepening" (also see Paus 2012, p. 117; Chandra and Kolavalli 2006, p. 19). 
In the final analysis, all types of emerging states will be required to pay greater attention to the improvement of the technological capabilities of their firms and labor forces. For this purpose, close interest coordination must be fulfilled among big firms, upstream and downstream firms, and labor force.

On the other hand, the analysis in Sect. 2.4.2 shows that greater global integration and resultant economic growth have not necessarily brought social equity and cohesion. Although economic growth itself helps improve income distribution in many cases, the role of the public sector continues to be important in ensuring the social welfare of the general population. As with technological upgrading, such welfare policies require political coordination of the distribution of burdens and benefits among domestic players.

\subsubsection{Coordination Capability for Technological Upgrading and Inclusive Growth}

As discussed in Sect. 2.5, many scholarly works agree that governing institutions' strong coordination capabilities frequently stem from their "embedded autonomy." They must have an internal cohesiveness and institutional capacity that can help ward off capture by particularistic interests and prioritize long-term national goals. At the same time, they must maintain close cooperative and consultative relations with social and economic actors to effectively monitor the market and social situations and secure the adoption and implementation of optimal policies. There are several factors we need to consider in our assessment of the prospects of each emerging state to maintain, strengthen, or build such capabilities anew.

First, some scholars say that private local firms have been enhancing their influence vis-à-vis state institutions. As early as 1995, Evans warned that domestic firms were strengthening their ties with MNCs while distancing themselves from the state; as a result, the "embedded autonomy" of the state may be undermined. Twenty years later, Yeung (2016) argued that economic success no longer depended on national states but on the development of GPNs based on close connections among private firms that extend beyond national borders. If any role remains for the government, it will be primarily to assist national-global articulation by helping domestic firms seek out specialized niches within the global economy. If this is the dominant tendency in the contemporary world, much of the work of coordinating interests to promote technological upgrading and inclusive growth will have to be left primarily in the hands of domestic private firms and their global allies. Room for coordination from a national point of view will be narrowed unless the private sector itself has a mechanism that can broadly coordinate the interests of big firms (both domestic and multinational), smaller suppliers and other domestic firms, workers, and people left out of the economic globalization process.

Second, the implications of the growing middle-class conservatism for "embedded autonomy" must be considered. Many authors point out an amazing expansion 
of the middle class in the emerging states (ADB 2010; Chen 2013; Ferreira et al. 2013; Power 2016). At the same time, several authors observe that this middle class is increasingly conservative in political terms. For instance, Kurlantzick (2013) contends that middle-class people feel threatened by the post-Cold War trend of democratization because democracy usually empowers the poor more than the middle class and endangers the middle class's economic, political, and social privileges. As a consequence, members of the middle class support authoritarian leaders in many countries, including Thailand, Venezuela, Russia, and China. Writing on the military coup of 2014 and its aftermath in Thailand, Kanchoochat (2016) observes that many professionals supported the coup and participated in the post-coup government. Reid (2014, Chap. 13) discerns increasing dissatisfaction among members of the Brazilian middle class and their participation in street demonstrations against the elected left-wing government. Middle-class conservatism does not necessarily mean a decline in the coordination capabilities of public institutions. As middle-class people's prosperity largely depends on continuing economic growth, they may support efforts to promote national technological upgrading. However, if their conservatism deters them from serving as a counterbalance against powerful private enterprises, it may end up dampening the effort to broaden and deepen domestic linkages to build technological capabilities and foster income redistribution.

Third, the mobilization of low-income people can impact the capability of public institutions. As the economies of the emerging states grew quickly, income levels even at the bottom of the economic ladder increased, raising people's expectations for an even better material life. Such expectations may put pressure on political leaders to enhance redistributive measures, thereby jeopardizing growth-oriented activities by strengthening the middle-class conservatism mentioned above and potentially frightening away private investors. Impediments to economic activities will become even more serious if political leaders attempt to mobilize the masses using populist rhetoric and practices. Reid (2014) mentioned the economic and political upheaval during the second half of the Labor Party's administration in Brazil, while Güven (2016) argued that the increasingly populist policies of the AKP government have impeded the structural transformation of the Turkish economy. The confusion and stagnation caused by the Thaksin administration and the subsequent coup is another well-known example of a populist debacle. In such a situation, we cannot expect public institutions to achieve effective interest coordination pertinent to technological upgrading and equitable growth.

Fourth, historical legacies that take the form of institutional path-dependence and ideational persistency may constrain the coordination capabilities of emerging states. As I mentioned in Sect. 2.4.3, Slater (2010) differentiated the "ordering power" of Southeast Asian states and attributed the divergence to each country's historical experiences of domestic crises threatening their elites. Doner et al. (2005) argued that institutional complexes that promote technological upgrading developed in South Korea, Taiwan, and Singapore to a greater extent than in other Southeast Asian countries. This difference originates from different historical experiences of internal and external crises. On the other hand, authors such as Bruce Gilley and Elizabeth Thurbon emphasize the importance of the ideational influence of the past. Gilley (2014) 
contends that the concept of the "virtuous ruler" persists throughout Asian history. This notion is supported by a shared culture that prioritizes the state-run by virtuous political leaders committed to the common good and constrained by the social norms of accountability - as the key entity guaranteeing national integrity, people's wellbeing, political stability, and economic development. Writing about contemporary South Korea, Thurbon (2016) echoes Gilley by saying that the "developmental mindset" persists not only among politicians and state officials but also in the population at large, and that this mindset helped bring about the resurgence of once-weakened public financing for high-tech industries. Institutional and ideational legacies may reinforce the coordination capabilities of public institutions. They may, however, jeopardize such capabilities if state elites behave in a self-righteous or predatory way without paying proper attention to the economic and social conditions of the nation.

Last but not least, political leadership may make a difference. Where a nation's historical legacies support strong public institutions, top leaders' policy choices will affect the degree to which the legacies are effectively utilized to strengthen the nation's coordination capabilities. Where historical legacies are not quite appropriate for the embedded-autonomy mode of interest coordination, leaders can still try to introduce institutions that limit the number of veto players in order to facilitate interest coordination. Furthermore, institutions that facilitate coordination will be more resilient if they are endorsed by a range of social and economic forces that support the broadening and deepening of domestic linkages. ${ }^{11}$ To do so, political elites need to build a firm and stable coalition of these forces while resisting the temptation of populist mobilization or the comfort of the conservative status quo.

\subsection{Concluding Remarks}

Somewhat ironically, we are currently witnessing strong antagonism toward globalization in some "advanced" industrial countries more so than in emerging states. The latter have successfully skirted the constraints of institutional globalization and have taken advantage of economic globalization in order to catch up with the advanced countries. Provided that the current anti-globalization mood in some advanced countries does not turn into long-term protectionist policies that spread across the world, some of the upper-middle-income emerging states will attain a high-income status, and some small but rapidly growing countries will achieve the status of emerging states in the years to come.

In order to productively integrate into the economic globalization process and benefit from it, emerging states have attracted global investors/traders by providing advantage factors such as large domestic markets, abundant natural resources, appropriate technological capabilities, or a combination thereof. In the final analysis, however, upgrading the technological capabilities of domestic firms and the

\footnotetext{
${ }^{11}$ Teichman (2016, p. 25) argues that a broad, cross-class consensus will help bolster the state's capacity and political will to pursue inclusive development.
} 
domestic labor force, along with strengthening domestic production linkages, will be crucial for the emerging states to advance further. They will also need to enhance redistributive measures and reinforce social linkages by narrowing the gap between the globally integrated populations and regions and those that have been left behind. Otherwise, anti-globalism, as witnessed in some advanced countries, may also flare up in the emerging states.

Strengthening both kinds of linkages requires a strong commitment to coordination among economic and social forces such as large enterprises, local suppliers, workers, the middle class, and disadvantaged people. In this sense, it is a political rather than an economic and/or technical endeavor, and, consequently, public institutions must be involved.

As for the future of the emerging states, this chapter presented five factors that can affect their coordination capability. These were identified as firm-government relations ("embedded autonomy"), middle-class conservatism, populist mobilization, institutional and ideational legacies of the past, and political leadership. Related to historical legacies and political leadership, institutional arrangements that promote a higher level of coordination capability must be explored. This chapter indicates that macro-institutions such as political regimes are not associated with the economic and social performance of emerging states, and therefore it focused on the bureaucracy as an example of micro-level institutions. The bureaucracy is certainly among the most important micro-level institutions that affect the coordination capability of national states. However, deeper and broader examination of the bureaucracy and other institutions is needed as it is beyond the scope of this chapter.

This chapter concludes by contending that the five factors mentioned above will undoubtedly affect the future trajectories of emerging states; as such, they should certainly be counted as major themes in emerging state studies.

\section{Appendix 1: GDP Growth Rate and GDP Per Capita}

\begin{tabular}{l|l|l|l}
\hline & $\begin{array}{l}\text { GDP growth rate } \\
\text { between } 1990 \text { and } \\
2014\end{array}$ & $\begin{array}{l}\text { GDP as percent of US } \\
\text { GDP in 2014 }\end{array}$ & $\begin{array}{l}\text { GDP per capita at } \\
\text { current US\$ in 2014 }\end{array}$ \\
\hline \multicolumn{4}{l}{ High-income countries } \\
\hline Singapore & 316 & 1.7 & 56,007 \\
\hline Taiwan & 231 & 3.1 & 22,626 \\
\hline South Korea & 227 & 7.6 & 27,989 \\
\hline Chile & 221 & 1.6 & 14,566 \\
\hline Saudi Arabia & 165 & 4.0 & 24,406 \\
\hline Poland & 136 & 3.3 & 14,337
\end{tabular}

(continued) 
(continued)

\begin{tabular}{|c|c|c|c|}
\hline & $\begin{array}{l}\text { GDP growth rate } \\
\text { between } 1990 \text { and } \\
2014\end{array}$ & $\begin{array}{l}\text { GDP as percent of US } \\
\text { GDP in } 2014\end{array}$ & $\begin{array}{l}\text { GDP per capita at } \\
\text { current US\$ in } 2014\end{array}$ \\
\hline Russia & 19 & 10.4 & 13,902 \\
\hline \multicolumn{4}{|c|}{ Upper middle income countries } \\
\hline China & 899 & 50.9 & 7587 \\
\hline Malaysia & 284 & 1.9 & 11,307 \\
\hline Peru & 209 & 1.1 & 6549 \\
\hline Thailand & 170 & 2.4 & 5970 \\
\hline Turkey & 149 & 5.4 & 10,304 \\
\hline Iraq & 148 & 1.1 & 6336 \\
\hline Colombia & 135 & 2.2 & 7918 \\
\hline Argentina & 129 & 2.8 & 12,325 \\
\hline Iran & 126 & 2.9 & 5443 \\
\hline Brazil & 103 & 14.9 & 11,729 \\
\hline Algeria & 99 & 1.1 & 5484 \\
\hline Mexico & 90 & 7.3 & 10,351 \\
\hline Kazakhstan & 90 & 1.1 & 13,155 \\
\hline South Africa & 84 & 2.5 & 6472 \\
\hline Venezuela & 79 & 2.6 & 12,265 \\
\hline \multicolumn{4}{|c|}{ Lower middle income countries } \\
\hline India & 352 & 13.6 & 1577 \\
\hline Nigeria & 245 & 2.8 & 3203 \\
\hline Indonesia & 214 & 5.8 & 3500 \\
\hline Egypt & 165 & 1.5 & 3366 \\
\hline Philippines & 165 & 1.6 & 2873 \\
\hline Pakistan & 158 & 1.3 & 1315 \\
\hline United States & 78 & 100.0 & 54,398 \\
\hline
\end{tabular}

Note Income group classification is according to the definition (based on GNI per capita) by the World Bank. Sources Own calculation based on data from World Development Indicator database and ADB $(2000,2016)$. The GDP data used for the calculation of growth rates and ratios to US GDP are at constant 2010 US \$ for all the countries except Taiwan. For Taiwan, figures at current price are used due to the data limitation 


\section{Appendix 2: Institutional and Economic Globalization and GDP Growth Rate (Annual Average)}

\begin{tabular}{|c|c|c|c|c|c|c|}
\hline & Institutional & Economic g & obalization & & & GDP \\
\hline & & $\begin{array}{l}\text { Ratio of } \\
\text { trade to } \\
\text { GDP, } \\
\text { average for } \\
2003-14\end{array}$ & $\begin{array}{l}\text { Ratio of } \\
\text { inward FDI } \\
\text { to GDP, } \\
\text { average for } \\
2003-15\end{array}$ & $\begin{array}{l}\text { Share of } \\
\text { trade in } \\
\text { world total } \\
\text { trade, } \\
2003-14\end{array}$ & $\begin{array}{l}\text { Share of } \\
\text { inward FDI } \\
\text { in world } \\
\text { total FDI, } \\
2003-15\end{array}$ & \\
\hline Algeria & 54.5 & 68 & 1.2 & 0.25 & 0.13 & 3.6 \\
\hline Argentina & 51.5 & 36 & 2.1 & 0.36 & 0.56 & 5.7 \\
\hline Brazil & 58.5 & 26 & 2.5 & 1.14 & 3.43 & 3.5 \\
\hline Chile & 77.8 & 70 & 7.1 & 0.35 & 1.02 & 4.2 \\
\hline China & 52.4 & 54 & 2.2 & 10.94 & 7.22 & 10.0 \\
\hline Colombia & 64.3 & 37 & 3.9 & 0.27 & 0.74 & 4.7 \\
\hline Egypt & 56.2 & 53 & 3.7 & 0.26 & 0.41 & 4.3 \\
\hline India & 53.8 & 47 & 1.8 & 2.35 & 1.85 & 7.6 \\
\hline Indonesia & 54.6 & 53 & 1.6 & 0.83 & 0.80 & 5.6 \\
\hline Iran & 43.9 & 49 & 0.9 & 0.33 & 0.22 & 3.4 \\
\hline Kazakhstan & 59.2 & 82 & 7.4 & 0.24 & 0.69 & 6.8 \\
\hline $\begin{array}{l}\text { South } \\
\text { Korea }\end{array}$ & 68.8 & 89 & 1.0 & 2.91 & 0.77 & 3.7 \\
\hline Malaysia & 64.2 & 174 & 3.2 & 0.97 & 0.55 & 5.2 \\
\hline Mexico & 66.2 & 59 & 2.5 & 2.03 & 1.94 & 2.5 \\
\hline Nigeria & 53.4 & 53 & 2.8 & 0.32 & 0.43 & 8.7 \\
\hline Peru & 65.2 & 49 & 4.4 & 0.21 & 0.46 & 5.9 \\
\hline Philippines & 57.3 & 79 & 1.3 & 0.39 & 0.17 & 5.4 \\
\hline Poland & 61.9 & 81 & 2.8 & 1.11 & 0.86 & 3.9 \\
\hline Russia & 51.2 & 52 & 2.5 & 1.65 & 2.59 & 4.1 \\
\hline $\begin{array}{l}\text { Saudi } \\
\text { Arabia }\end{array}$ & 62.7 & 84 & 3.6 & 1.13 & 1.30 & 6.0 \\
\hline Singapore & 87.8 & 390 & 19.0 & 2.33 & 2.96 & 6.1 \\
\hline $\begin{array}{l}\text { South } \\
\text { Africa }\end{array}$ & 63.6 & 59 & 1.5 & 0.48 & 0.36 & 3.1 \\
\hline Taiwan & 70.9 & 126 & 0.7 & 1.52 & 0.23 & 4.2 \\
\hline Thailand & 63.8 & 131 & 3.2 & 1.23 & 0.67 & 4.0 \\
\hline
\end{tabular}


(continued)

\begin{tabular}{|c|c|c|c|c|c|c|}
\hline & \multirow{2}{*}{$\begin{array}{l}\text { Institutional } \\
\text { globaliza- } \\
\text { tion } \\
\text { (Economic } \\
\text { freedom } \\
\text { score, } \\
2003-2014 \text { ) }\end{array}$} & \multicolumn{4}{|c|}{ Economic globalization } & \multirow{2}{*}{$\begin{array}{l}\text { GDP } \\
\text { growth rate } \\
(2003-14)\end{array}$} \\
\hline & & $\begin{array}{l}\text { Ratio of } \\
\text { trade to } \\
\text { GDP, } \\
\text { average for } \\
2003-14\end{array}$ & $\begin{array}{l}\text { Ratio of } \\
\text { inward FDI } \\
\text { to GDP, } \\
\text { average for } \\
2003-15\end{array}$ & $\begin{array}{l}\text { Share of } \\
\text { trade in } \\
\text { world total } \\
\text { trade, } \\
2003-14\end{array}$ & $\begin{array}{l}\text { Share of } \\
\text { inward FDI } \\
\text { in world } \\
\text { total FDI, } \\
2003-15\end{array}$ & \\
\hline Turkey & 59.1 & 52 & 1.9 & 1.03 & 0.92 & 4.8 \\
\hline Venezuela & 42.4 & 52 & 1.1 & 0.22 & 0.17 & 3.9 \\
\hline
\end{tabular}

Sources Economic Freedom Score is from own calculation based on Heritage Foundation's economic freedom scores (http://www.heritage.org/index, accessed on 21 November 2016); Ratio of trade to GDP is from own calculation based on data derived from World Development Indicator database and ADB (2016); Ratio of inward FDI, Share of trade in world total trade, and Share of inward FDI in world total FDI are from own calculation based on data derived from UNCTADSTAT database (http://unctadstat.unctad.org/wds/ReportFolders/ reportFolders.aspx?sCS_ChosenLang=en, accessed on 27 November 2016); GDP growth rate is from own calculation based on data derived from World Development Indicator database, ADB (2016), and IMF's Economic Outlook database

\section{References}

Aaron, F., Chani, E., \& Mishra, S. (2013). How to avoid middle income traps? Evidence from Malaysia. Policy Research Working Paper No. 6427. Washington, D.C.: The World Bank.

Acemoglu, D., \& Robinson, J. A. (2006). Economic origins of dictatorship and democracy. New York: Cambridge University Press.

Asian Development Bank (ADB). (2000). Key indicators for Asia and the Pacific 2000. Manila: ADB.

Asian Development Bank (ADB). (2010). Key indicators for Asia and the Pacific 2010. Manila: ADB.

Asian Development Bank (ADB). (2016). Key indicators for Asia and the Pacific 2016. Manila: ADB.

Birdsall, N. (2014). A note on the middle class in Latin America. In R. Kanbur, C. Rhee, \& J. Zhuang (Eds.), Inequality in Asia and the Pacific: Trends, drivers, and policy implications (pp. 257-287). Manila: ADB, UK: Routledge.

Breznitz, D., \& Murphree, M. (2011). Run of the red queen: Government, innovation, globalization, and economic growth in China. New Haven and London: Yale University Press.

Brownlee, J. (2007). Authoritarianism in an age of democratization. Cambridge: Cambridge University Press.

Caldentey, E. P. (2012). Income convergence, capability divergence, and the middle income trap: An analysis of the case of Chile. Studies in Comparative International Development, 47, 185-207.

Chandra, V., \& Kolavalli, S. (Eds.). (2006). Technology, adaptation, and exports: How some developing countries got it right. Washington, D.C.: The World Bank. 
Chen, J. (2013). A middle class without democracy: Economic growth and the prospects for democratization in China. Oxford and New York: Oxford University Press.

Coe, N. M., \& Yeung, H. W. (2015). Global production networks: Theorizing economic development in an interconnected world. Oxford: Oxford University Press.

Comisión Económica para América Latina y el Caribe (CEPAL). (2016). Panorama Social de América Latina 2015. Santiago: CEPAL.

Cotlear, D., Nagpal, S., Smith, O., Tandon, A., \& Cortez, R. (2015). Going universal: How 24 developing countries are implementing universal health coverage reforms from the bottom up. Washington, D.C.: International Bank for Reconstruction and Development/The World Bank.

Diamond, L. (2002). Thinking about hybrid regimes. Journal of Democracy, 13(2), 21-35.

Doner, R. F. (2009). The politics of uneven development: Thailand's economic growth in comparative perspective. Cambridge: Cambridge University Press.

Doner, R. F. (2015). Success as trap? Crises and challenges in export-oriented Southeast Asia. In T. J. Pempel \& K. Tsunekawa (Eds.), Two crises, different outcomes: East Asia and global finance (pp. 163-184). Ithaca and London: Cornell University Press.

Doner, R. F., \& Ramsay, A. (2003). The challenges of economic upgrading in liberalizing Thailand. In L. Weiss (Ed.), States in the global economy: Bringing domestic institutions back in (pp. 121-141). Cambridge: Cambridge University Press.

Doner, R. F., Ritchie, B. K., \& Slater, D. (2005). Systemic vulnerability and the origins of developmental states: Northeast and Southeast Asia in comparative perspective. International Organization, 59, 327-361.

Doner, R. F., \& Schneider, B. R. (2016). The middle-income trap: More politics than economics. World Politics, 68(4), 608-644.

Evans, P. (1995). Embedded autonomy: States and industrial transformation. Princeton: Princeton University Press.

Evans, P., \& Rauch, J. E. (1999). Bureaucracy and growth: A cross-national analysis of the effects of 'Weberian' state structures on economic growth. American Sociological Review, 64(5), 748-765.

Felipe, J., Abdon, A., \& Kumar, U. (2012). Tracking the middle-income trap: What is it, who is in it, and why? Levy Economics Institute of Bard College Working Paper No 715.

Ferreira, F. H. G., Messina, J., Rigolini, J., López-Calva, L., Lugo, M. A., \& Vakis, R. (2013). Economic mobility and the rise of the Latin American middle class. Washington, D.C.: The World Bank.

Friedman, T. L. (1999/2000). The lexus and the olive tree: Understanding globalization (Updated and Expanded ed.). New York: Farrar Straus Giroux.

Gill, I., \& Kharas, H. (2007). An East Asian renaissance: Ideas for economic growth. Washington, D.C.: The World Bank.

Gill, I., \& Kharas, H. (2015). The middle-income trap turns ten. World Bank Policy Research Working Paper No. 7403.

Gilley, B. (2014). The nature of Asian politics. New York: Cambridge University Press.

Güven, A. B. (2016). The political economy of Turkish democracy. In C. Erisen \& P. Kubicek (Eds.), Democratic consolidation in Turkey: Micro and macro challenges (pp. 184-203). London and New York: Routledge.

Holliday, I. (2000). Productivist welfare capitalism: Social policy in East Asia. Political Studies, 48(4), 706-723.

Huntington, S. P. (1991). The third wave: Democratization in the late twentieth century. Norman: University of Oklahoma Press.

Intarakumnerd, P. (2017). Industrial innovation in Thailand: The electronics, automotive and seafood sectors. In B. T. Khoo \& K. Tsunekawa (Eds.), South East Asia beyond traps and crises: Economic growth and upgrading (pp. 167-192). London: Palgrave Macmillan.

Jessop, B. (2016). The developmental state in an era of finance-dominated accumulation. In Y.-W. Chu (Ed.), The Asian developmental state: Reexaminations and new departures (pp. 27-55). Basingstoke, UK: Palgrave Macmillan. 
Kanchoochat, V. (2016). Reign-seeking and rise of the unelected in Thailand. Journal of Contemporary Asia, 46(3), 486-503.

Kaplan, S. B. (2013). Globalization and austerity politics in Latin America. Cambridge: Cambridge University Press.

Kawano, M. (2017). Upgrading Malaysia's rubber manufacturing: Trajectories and challenges. In B. T. Khoo \& K. Tsunekawa (Eds.), South East Asia beyond traps and crises: Economic growth and upgrading (pp. 193-223). London: Palgrave Macmillan.

Kim, M. M. S. (2016). Comparative welfare capitalism in East Asia: Productivist models of social policy. New York: Palgrave Macmillan.

Kohli, H. S., Sharma, A., \& Sood, A. (Eds.). (2011). Asia 2050: Realizing the Asian century. Los Angeles, London, New Delhi, Singapore, and Washington, DC: Sage Publications.

Kurlantzick, J. (2013). Democracy in retreat: The revolt of the middle class and the worldwide decline of representative government. New Haven \& London: Yale University Press.

Kwon, H.-J. (2002). Welfare reform and future challenges in the Republic of Korea: Beyond the developmental welfare state? International Social Security Review, 55(4), 23-38.

Levitsky, S., \& Way, L. A. (2010). Competitive authoritarianism: Hybrid regimes after the cold war. Cambridge: Cambridge University Press.

MacIntyre, A. (2003). The power of institutions: Political architecture and governance. Ithaca and London: Cornell University Press.

Maddison, A. (1995). Monitoring the world economy 1820-1992. Paris: OECD.

Mosley, L. (2003). Global capital and national governments. Cambridge: Cambridge University Press.

Murillo, M. V. (2001). Labor unions, partisan coalitions, and market reform in Latin America. Cambridge and New York: Cambridge University Press.

Ohmae, K. (1990). The borderless world: Power and strategy in the interlinked economy. Harper Business.

Ohmae, K. (1996). The end of the nation state: The rise of regional economies. New York: Simon \& Schuster Inc.

Ohno, K. (2009). Avoiding the middle-income trap: Renovating industrial policy formulation in Vietnam. ASEAN Economic Bulletin, 26(1), 25-43.

Oikawa, H. (2015). Mareshia pamuyu sangyo no hatten to shigen riyogata kyacchiappu kogyoka [Development of Malaysian palm oil industry and resource-based catching-up industrialization]. Ajia Keizai [Asian Economy], 56(2), 41-71.

Paus, E. (2012). Confronting the middle income trap: Insights from small latecomers. Studies in Comparative International Development, 47(2), 115-138.

Polanyi, K. (2001). The great transformation: The political and economic origins of our time. Second Beacon Paperback edition. First published 1944.

Power, T. J. (2016). The reduction of poverty and inequality in Brazil: Political causes, political consequences. In B. R. Schneider (Ed.), New order and progress: Development and democracy in Brazil (pp. 212-237). New York: Oxford University Press.

Ramesh, M. (2003). Globalization and social security expansion in East Asia. In L. Weiss (Ed.), States in the global economy: Bringing domestic institutions back in (pp. 83-98). Cambridge: Cambridge University Press.

Rasiah, R. (2006). Explaining Malaysia's export expansion in palm oil and related products. In V. Chandra (Ed.), Technology, adaptation, and exports: How some developing countries got it right (pp. 163-192). Washington, D.C.: The World Bank.

Reid, M. (2014). Brazil: The troubled rise of a global power. New Haven and London: Yale University Press.

Rock, M. T. (2013). East Asia's democratic developmental states and economic growth. Journal of East Asian Studies, 13, 1-34.

Rodrik, D. (1997). Has globalization gone too far?. Washington, D.C.: Institute for International Economics. 
Rodrik, D. (2007). One economics, many recipes: Globalization, institutions, and economic growth. Princeton and London: Princeton University Press.

Rodrik, D. (2011). The globalization paradox: Why global markets, states, and democracy can't coexist. Oxford: Oxford University Press.

Schedler, A. (2013). The politics of uncertainty: Sustaining and subverting electoral authoritarianism. Oxford: Oxford University Press.

Schneider, B. R. (2013). Hierarchical capitalism in Latin America: Business, labor, and the challenges of equitable development. New York: Cambridge University Press.

Sihna, A. (2016). Globalizing India: How global rules and markets are shaping india's rise to power. Cambridge: Cambridge University Press.

Slater, D. (2010). Ordering power: Contentious politics and authoritarian leviathans in Southeast Asia. Cambridge: Cambridge University Press.

Stampini, M., \& Tornarolli, L. (2012). The growth of conditional cash transfers in Latin America and the Caribbean: Did they go too far? Social Sector, Social Protection and Health Division (Inter-American Development Bank) Policy Brief No. 185.

Strange, S. (1996). The retreat of the state: The diffusion of power in the world economy. Cambridge: Cambridge University Press.

Suehiro, A. (2017). New growth strategies of Thailand's big firms in the ASEAN economic community era. In B. T. Khoo \& K. Tsunekawa (Eds.), South East Asia beyond traps and crises: Economic growth and upgrading (pp. 35-69). UK: Palgrave Macmillan.

Teichman, J. A. (2001). The politics of freeing markets in Latin America: Chile, Argentina and Mexico. Chapel Hill and London: The University of North Carolina Press.

Teichman, J. A. (2016). The politics of inclusive development: Policy, state capacity, and coalition building. Basingstoke and New York: Palgrave Macmillan.

Thurbon, E. (2016). Developmental mindset: The revival of financial activism in South Korea. Ithaca and London: Cornell University Press.

Weiss, L. (1998). The myth of the powerless state: Governing the economy in a global era. Cambridge: Polity Press.

Weiss, L., \& Hobson, J. M. (1995). States and economic development: A comparative historical analysis. UK: Policy Press.

Wibbels, E. (2006). Dependency revisited: International markets, business cycles, and social spending in the developing world. International Organization, 60, 433-468 (Spring).

World Bank. (2000). World development report 2000/2001: Attacking poverty. Washington, D.C.: The World Bank.

Yeung, H. W. (2016). Strategic coupling: East Asian industrial transformation in the new global economy. Ithaca and London: Cornell University Press.

Yusuf, S. (2004). Competitiveness through technological advances under global production networking. In S. Yusuf, M. A. Altaf, \& K. Nabeshima (Eds.), Global production networking and technological change in East Asia (pp. 1-34). Washington, DC: The World Bank.

Yusuf, S., \& Nabeshima, K. (2009). Tiger economies under threat: A comparative analysis of Malaysia's industrial prospects and policy options. Washington DC: World Bank. 
Open Access This chapter is licensed under the terms of the Creative Commons AttributionNonCommercial-NoDerivatives 4.0 International License (http://creativecommons.org/licenses/bync-nd/4.0/), which permits any noncommercial use, sharing, distribution and reproduction in any medium or format, as long as you give appropriate credit to the original author(s) and the source, provide a link to the Creative Commons license and indicate if you modified the licensed material. You do not have permission under this license to share adapted material derived from this chapter or parts of it.

The images or other third party material in this chapter are included in the chapter's Creative Commons license, unless indicated otherwise in a credit line to the material. If material is not included in the chapter's Creative Commons license and your intended use is not permitted by statutory regulation or exceeds the permitted use, you will need to obtain permission directly from the copyright holder.

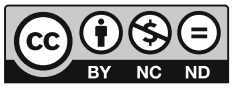




\title{
Chapter 3 \\ The Asian Path of Economic Development: Intra-regional Trade, Industrialization and the Developmental State
}

\author{
Kaoru Sugihara
}

\begin{abstract}
This chapter discusses the Asian path of economic development from a long-term historical perspective. It is an attempt to understand the regionally specific context in which current emerging economies, especially India, Southeast Asia and China, industrialized. The basic demographic regime of monsoon Asia was formed in the early modern period, in which China and India developed a very large population-carrying capacity. The path of economic development was sustainabilitydriven, rather than growth-driven. In the nineteenth century and the first half of the twentieth century regional integration took place under the Western impact, which led to the growth of intra-regional trade and labour-intensive industrialization. A fully-fledged industrialization, with a rapid rise in living standards, followed in the second half of the twentieth century. In Japan the developmental state promoted national land development plans, and fostered capital- and resource-intensive industries in the seafront industrial complex along the Pacific coast. The development path of the countries in the Western Pacific rim at least partially became resourceintensive and growth-driven. In the most recent period, China extended this seafront model to a more comprehensive resource nexus model, which would enable the integration of the non-maritime parts of the country and the Eurasian continent into its growth orbit. This development requires a fuller mobilization of less tradable resources, such as water and ecosystem services, putting pressure on local resources and raising questions about environmental sustainability. The developmental state seeking both industrialization and environmental sustainability plays a crucial role in determining the future of Asia's development path.
\end{abstract}

\section{K. Sugihara $(\bowtie)$}

Research Institute for Humanity and Nature, Kyoto, Japan

e-mail: sugiharak83@gmail.com 


\subsection{Intra-Asian Trade as a Key Agent of Regional Industrialization}

This chapter discusses Asia's regional path of economic development, focussing on trade, industrialization and the developmental state. It is an attempt to understand the regionally specific context in which current emerging economies (especially India, Southeast Asia and China) industrialized from a long-term historical perspective.

In my previous work I suggested that the growth of intra-Asian trade was faster than that of world trade or Asia's trade with the West between 1880 and 1938 (Sugihara 1996, 2005: see Fig. 3.1 and Table 3.1). This was in sharp contrast to many parts of Africa, Middle East and Latin America where the local economies were integrated into the metropolis-led international economy as a satellite. Asian countries involved in this intra-regional trading network included a number of European colonies in South and Southeast Asia, as well as countries of East and Southeast Asia under unequal treaties and the treaty port system. They interacted with one another much more than other developing worlds did, through the growth of Indian, Chinese and other Asian merchant networks. It was these networks, together with the Japanese trade associations and government efforts to help them to compete with Asian networks (see Sugihara 1994), that facilitated the Japanese exports of labourintensive manufactured goods to other Asian countries. The growth of intra-Asian trade was instrumental to Japan's labour-intensive industrialization.

After a heavy intervention of the emergence, development and abrupt collapse of the Yen bloc in the 1930s and the first half of the 1940s, intra-Asian trade recovered
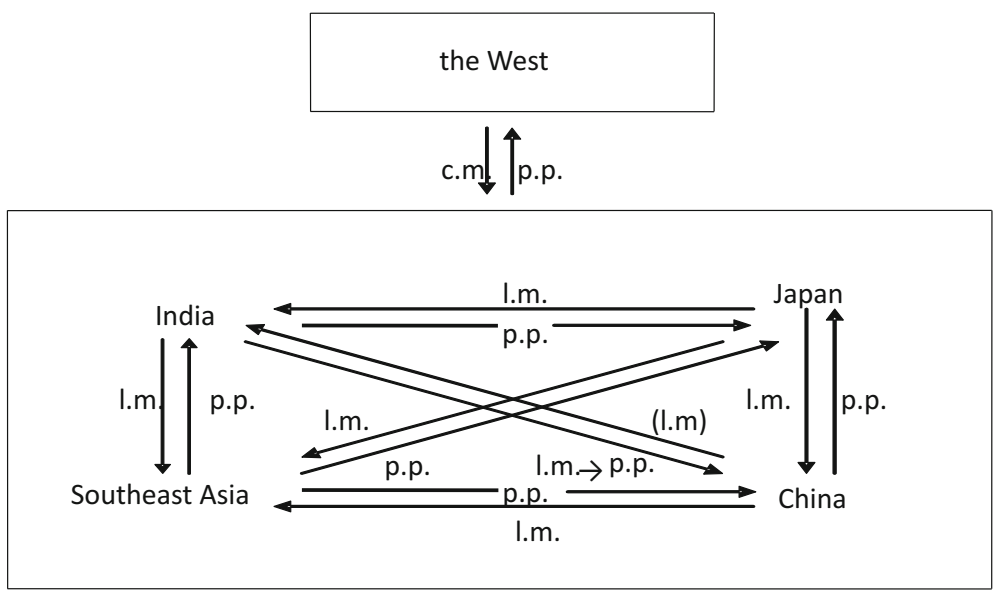

Fig. 3.1 Intra-Asian trade, c. 1880-1938 Source and notes c.m. capital-intensive manufactured goods, 1.m. labour-intensive manufactured goods, p.p. primary products. Since the late nineteenth century India exported cotton yarn to China in large quantities, but from the end of the 1910s, it was replaced by the exports of raw cotton. China exported a small amount of silk textiles in turn. Sugihara (1996): slightly revised 
3 The Asian Path of Economic Development: Intra-regional ...

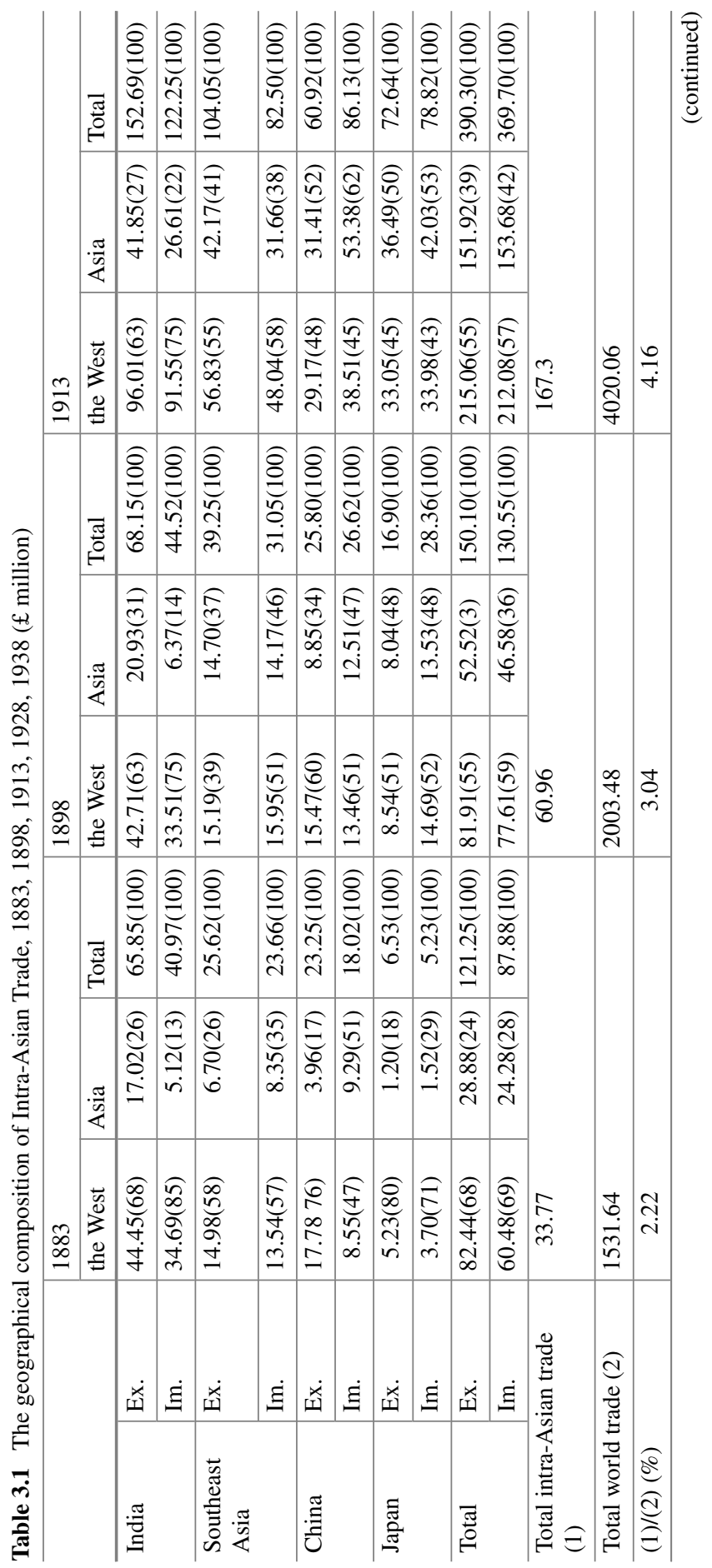




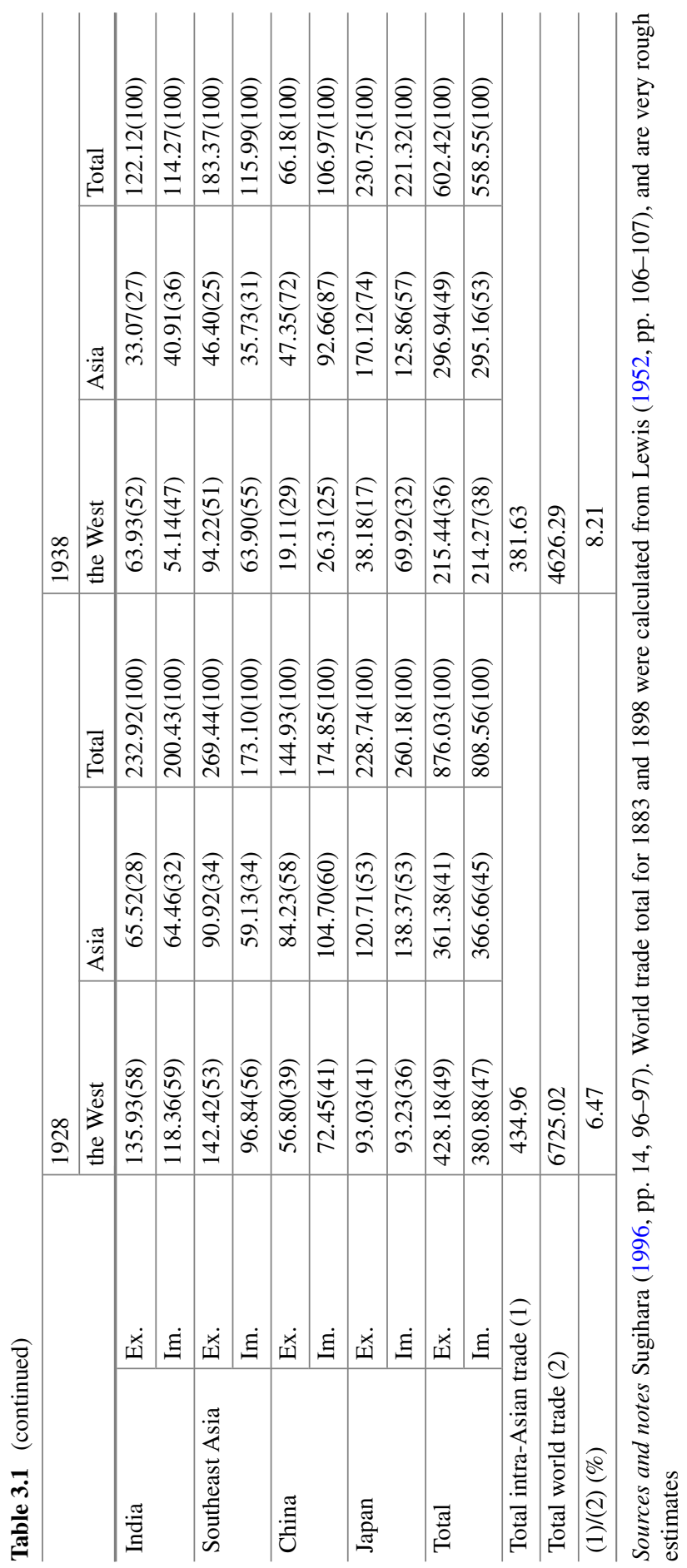


Table 3.2 Growth of Intra-Asian trade, 1950-2014 (billion dollars)

\begin{tabular}{|c|c|c|c|c|c|c|c|}
\hline \multirow[b]{2}{*}{1950} & \multicolumn{2}{|c|}{$\begin{array}{l}\text { (1) World exports } \\
\text { total }\end{array}$} & \multicolumn{2}{|c|}{ (2) Asia exports total } & \multicolumn{2}{|c|}{$\begin{array}{l}\text { (3) Intra-Asian trade } \\
\text { total }\end{array}$} & \multirow{2}{*}{\begin{tabular}{|l}
$\begin{array}{l}(3) /(2) \\
(\%)\end{array}$ \\
27.1 \\
\end{tabular}} \\
\hline & 58.0 & (100.0) & 10.7 & $(18.4)$ & 2.9 & $(5.0)$ & \\
\hline 1955 & 93.9 & $(100.0)$ & 13.4 & $(14.3)$ & 4.0 & (4.3) & 29.9 \\
\hline 1960 & 128.9 & $(100.0)$ & 18.3 & $(14.2)$ & 5.9 & (4.6) & 32.2 \\
\hline 1965 & 188.2 & $(100.0)$ & 25.7 & $(13.7)$ & 9.1 & (4.8) & 35.4 \\
\hline 1970 & 320.7 & $(100.0)$ & 44.4 & $(13.8)$ & 15.6 & (4.9) & 35.1 \\
\hline 1975 & 887.4 & $(100.0)$ & 143.4 & $(16.2)$ & 49.8 & (5.6) & 34.7 \\
\hline 1980 & 2018.1 & $(100.0)$ & 332.6 & $(16.5)$ & 135.9 & $(6.7)$ & 40.9 \\
\hline 1985 & 1987.0 & $(100.0)$ & 424.2 & $(21.3)$ & 167.7 & (8.4) & 39.5 \\
\hline 1990 & 3601.2 & $(100.0)$ & 805.4 & $(22.4)$ & 357.3 & $(9.9)$ & 44.4 \\
\hline 1995 & 5325.1 & $(100.0)$ & 1460.6 & $(27.4)$ & 764.8 & (14.4) & 52.4 \\
\hline 2000 & 6385.6 & $(100.0)$ & 1456.8 & $(22.8)$ & 738.9 & (11.6) & 50.7 \\
\hline 2005 & 10369.0 & $(100.0)$ & 2285.5 & $(22.0)$ & 1330.0 & $(12.8)$ & 58.2 \\
\hline 2010 & 14937.3 & (100.0) & 4495.3 & $(30.1)$ & 3073.9 & (20.6) & 68.4 \\
\hline 2014 & 18442.9 & (100.0) & 5603.2 & $(30.4)$ & 3905.9 & $(21.2)$ & 69.7 \\
\hline
\end{tabular}

Sources and notes Takanaka (2000). For figure from 2000 onwards, IMF, Direction of Trade Statistics Yearbook. The former work is based on UN commodity trade statistics, which is slightly wider in the scope of coverage than the IMF data, but the differences are small. Intra-Asian trade total refers to the value of exports from ten Asian countries (Japan, four NIEs, four ASEAN countries and China) and their imports from the smaller Asian countries (adjusted by FOB-CIF conversion)

fast among a much smaller number of countries in the post-war period. India, China and many Southeast Asian countries and North Korea withdrew from the regime of free trade, and a relatively small number of countries along the western Pacific coast (Japan, South Korea, Taiwan, Hong Kong and Malaya-Singapore among others) were integrated into the U.S.-led world economy. We then saw the high-speed growth of Japan, NIEs and ASEAN 4, followed by the reintegration of China, Southeast Asian countries (which joined ASEAN later) and India in the second half of the twentieth century, which led to a full recovery of the intra-Asian trading zone that existed in 1928. In the early post-war period the share of U.S. (and other Western countries) in Asia's trade was large, and its influence was dominant. However, the U.S. share rapidly declined, and was replaced by the growth of regionally-driven trade. In 2014 the share of intra-Asian trade in Asia's exports was as much as $70 \%$, a figure comparable to intra-E.U. trade (see Table 3.2). It has been by far the most dynamic section of world trade for the last half century.

Why has the growth of intra-regional trade been such a persistent tendency for the last hundred and thirty years? Our hypothesis is that there has been a dynamic relationship between the growth of intra-Asian trade and industrialization on a regional scale. That is, the growth of intra-Asian trade from the late nineteenth century helped Japan's labour-intensive industrialization, which in turn provided cheap manufac- 
tured goods such as cotton textiles and sundries to Asian peoples, and made the commodity composition of intra-Asian trade increasingly industrialization-driven. In the interwar period China went through import-substitution industrialization, which urged Japanese manufacturers to find more processed or higher-value added products for exports. Under the regime of 'selective' protectionism, Japanese manufacturers further increased the exports of textile machinery to China, which started regional industrialization. This was an original 'flying geese' (Akamatsu 1962), which has become a basic mechanism of progressively including higher value-added commodities and commodities made with the more advanced technology in intra-regional trade. The regional drive also targeted at opening up new markets for modern manufactured goods. Asian merchants and producers exploited the opportunity to identify local tastes and consumption patterns and to create a diverse range of demand for cotton cloth and sundries across Asia and beyond (think of exports of Indian and later Japanese cotton cloth to Southeast Asia and East Africa).

The post-war diffusion of industrialization, beginning in Japan and spreading to other Asian countries, has followed the same interactive path between intra-regional trade and industrialization, first among a small number of countries under the regime of free trade, and gradually embracing others [think of Asian textile complex in the 1980s in which Japan produced rayon [yarn], Taiwan wove it, and Hong Kong made it an apparel and exported it to the United States. See Arpan (1984: 112-117, 136-149, 159)]. Again, we do not see such a dynamic relationship in Africa, Middle East or Latin America in this period. South Africa and Brazil proceeded with industrialization without accompanying regional integration. It is only in Asia that economic nationalism has embraced regional integration on a regional scale. This trend continues to this day, most recently in the shape of the ASEAN Economic Community, and in spite of the emergence of China as a hegemon. By now labour-intensive industries reached many low-income countries (Sugihara 2013b).

This chapter is concerned with how such a distinctive feature has emerged. The key concept is intra-regional trade, as distinct from both local and long-distance trade. It created a regional division of labour between a commercial agricultural region and a proto-industrial region, and embraced industrialization by broadening the commodity composition of their trade. Its main career has been merchant networks, rather than the modern organization with the head office and a visible (Chandlerenian organizational) organizational structure, and both types remain important as careers of trade to this day. Intra-regional trade did not involve state monopolies such as European East India Companies, a product of mercantilism, but went hand in hand with the government policy of promoting trade and industrialization. In Southeast Asia, merchant networks were often responsible for the state formation in port cities and their hinterlands, which in turn provided institutional foundations of these networks. Where the power of the state was weak, merchant networks themselves organized schools, hospitals and social functions, to facilitate personal networks and information flows. Today they exist in the forms of overseas Chinese business associations, for example.

Implicit in these statements is that adopting a single country-based framework (e.g. Japanese history, Indonesian history) and considering intra-regional trade as a minor 
modification of such a framework are insufficient for the understanding of the context in which "emerging economies" reached the current level of development. What needs to be explained is how Asia as a region acquired global economic significance.

In the next section, I describe the pre-industrial roots of intra-regional trade and its relationships with the state, which governed the mobilization of resources. I argue that basic demographic profiles of these countries have been formed during the early modern period, and that China and India respectively developed a path, which was able to hold a very large population. It was a sustainability-driven, rather than growthdriven, path. In the nineteenth century and the first half of the twentieth century regional integration took place under the Western impact, which led to the growth of intra-regional trade and labour-intensive industrialization. Population growth became more regional, with a modest rise in living standards, especially in the maritime parts of Asia.

A fully-fledged industrialization, with a rapid rise in living standards, followed in the second half of the twentieth century. In the third section I discuss the post-war dynamics of intra-Asian trade and industrialization, focussing on the mobilization of labour and capital. Labour-intensive industrialization entailed the improvement of the quality of labour and livelihood, expressed in the Human Development Index, while capital- and resource-intensive industrialization was accompanied by the improved access to global resources. In Japan the developmental state promoted national land development plans, and fostered capital- and resource-intensive industries in the seafront industrial complex along the Pacific coast. The development path of the countries in the Western Pacific rim at least partially became resource-intensive and growth-driven. In the most recent period, China extended this seafront model to a more comprehensive resource nexus model, which would enable the integration of the non-maritime parts of the country and the Eurasian continent into its growth orbit. This development requires a fuller mobilization of less tradable resources, such as water and ecosystem services, putting pressure on local resources and raising questions about environmental sustainability. In the fourth section I discuss the importance of local resource constraints for the developmental state seeking both industrialization and environmental sustainability. The final section summarizes the main points of this chapter.

\subsection{Pre-industrial Roots and Trade Integration: the Western Impact}

\subsubsection{State Formation in Agrarian and Maritime Asia}

In understanding political and institutional foundations of Asia, it is important to go back to the evolution of state formation in the early modern period. The economic base of the state formation can be classified into three types: maritime, agrarian and nomadic. In both Mughal India and Qing China the nomadic empire came to rule 
a vast agrarian society, and transformed itself into the agrarian empire to a large extent. Judging by population size, these two agrarian empires were much larger than nomadic empires (the Ottoman empire was both nomadic and agrarian, but its population was smaller than the other two) and other earlier ones spanning vast regions of Eurasia. Within the environmental framework of monsoon Asia agrarian empires and their offshoots, including Japan, played a central role in the growth of population and the idea of welfare provision to sustain it. It was the agrarian empire that developed a regime of livelihood and resource security for ordinary people.

Various types of empires, states and other regional and international bodies tried to secure resources for their own survival and expansion. Among the most important means deployed were fiscal policy (typically tax extraction) and trade and territorial expansion. While in early modern Europe the execution of war was closely related to the issue of bonds and shares in the capital market, this was not the case in Asia. Land tax, together with monopoly sales, tariff, toll tax etc., served for the needs of the war, law and order, and the consumption of the ruling class. The Mughal Empire and the Tokugawa shogunate were perhaps the two states that extracted the highest proportion of agricultural output in the seventeenth century.

What made it possible for them to extract such a heavy tax for a long time? The main source was agricultural surplus. The source of surplus came from the high land productivity of rice agriculture in monsoon Asia where plenty of water and rich land were available, and labour-intensive technology and labour-absorbing institutions were developed. The 'industrious revolution' occurred both in Western Europe and East Asia, but it was in the latter that labour absorption led to population growth (Sugihara and Wong 2015).

The population-sustaining capacity was supported by the local community, as well as by an agrarian empire or state. In many peasant societies, including relatively land-scarce ones, village autonomy was guaranteed to a certain extent, as long as the village paid land tax and fulfilled other obligations. This was another way of providing livelihood and resource security. Within the local community welfare was provided by the family, the village community, market mechanisms and local hierarchies. In this case, the shape of centralized power differed region by region, in terms of the size of revenue, the extent of currency manipulation (by debasement and issuance of paper money), external policy, and the degree of freedom of migration. There was also diversity in the relationships between central and local governments. In the history of commons and common pool resources, institutions to deal with communal land emerged relatively early in land-scarce regions such as Japan and South India, while response to deforestation or decline of fish stocks came much later in resource-rich regions of Southeast Asia (Yanagisawa 2015).

Livelihood and resource security concerns in this period included not just the acquisition of food, shelter and clothing, but the more specific capacity to secure food during famine or food shortages and response to infectious diseases, disasters and war. While strong states were capable of destroying the livelihood of their people by conducting war or suppressing resistance, early modern states were also interested in the welfare of the people who were the foundation of their power. In seventeenth to eighteenth-century China, granaries stored food in preparation of local food short- 
ages (Will and Wong 1991). The main social mechanism of resource allocation and livelihood security in India was the caste system, which combined occupational division with status hierarchy. In certain castes, work/income rights (shares) were recognized and exchanged, while water, as well as land, was used to signal and reinforce social organization and hierarchy. The Mughal Empire built sophisticated architecture (including provision of water and construction of deep wells), cities and a network of roads by bringing in artistic, scientific and technical knowledge from the Islamic and Western worlds. Some of the knowledge and infrastructure had (largely unintended) external effects on sustaining the agrarian population.

Meanwhile, maritime states based on port cities and surrounding rural areas grew along the coasts of the Indian Ocean, including maritime Southeast Asia. Here the key organizing agents were port cities (or port city states) and networks of merchants (Reid 1993, 62-131). Products derived from sea, land and forest were all involved in the exchange economy. Helped by the presence of Indian and Chinese merchants, the region emerged as a trading world in which long-distance trade, regional trade and local trade actively interacted. Nevertheless, states did not develop a capacity to hold a large population. Resources were freely transferred through trade. The states thrived when they consolidated power or were in touch with other regions, including Asian agrarian and European overseas empires. If the state was relatively urban or commercially oriented, it could shift its fiscal base from one commodity to another, or from one economic activity to another, relatively easily. This flexibility was one important strength for securing resources and livelihood. The first serious economic contacts with Europe often began via these states. But their livelihood security was often threatened by external shocks through the introduction of infectious diseases, loss of comparative advantage as a result of the emergence of new production methods and trade regimes, and violence and war, in addition to natural disturbances, especially famines.

In peninsular Southeast Asia three military-fiscal states coexisted and competed with each other with a tendency for territorial consolidation in a way similar to European polity (Lieberman 2003). Even here commerce was important. Agrarian population was not necessarily the mainstay (for the Ayutthaya, see Baker and Phongpaichit 2017). Meanwhile, in the mountainous areas spanning South and Southeast Asia and China, people formed small political entities and retained their linguistic and cultural identities (Scott 2009). Furthermore, the impact of Islam (and Arab merchants) on the state formation in Indian Ocean trade regions cannot be ignored. All these features coexisted with agrarian empires and maritime states in South, Southeast and East Asia, often competing, overlapping or complementing with them.

It is possible to see a tendency for the two types of political units, agrarian and maritime, to initiate or encourage the growth of the market along each path. For example, the Chinese empire discouraged maritime expansion to a certain extent, but left the development of local and regional markets without heavy intervention. In eighteenth-century Jiangnan, where labour-intensive rice farming had developed, a significant proportion of cotton cloth was exported from the region; In addition, water buffalos had to be imported, and manure was brought from the North, to raise agricultural productivity (Li 1998, Chaps. 3, 4 and 6). The Tokugawa government 
was much more regulatory. It promoted the growth of the central market of rice through the collection of land tax, managed foreign trade under strict control, partly discouraged other types of trade, and regulated the growth of factor markets (in land, labour and capital). It was nevertheless 'market-enhancing', in that the system allowed relative socio-political autonomy, and even encouraged the peasant household to engage in commercial agriculture and proto-industry, especially from the latter half of the eighteenth century. Finally, the East Asian maritime networks were governed by the tendency to regulate long-distance trade, which denied the European style of expansion backed by military and technological capabilities. But by the end of the seventeenth century, pirate activities were curtailed, and East Asian seas became peaceful. In addition to, and partly in replacement of, the tributary trade relations, China developed a more equal regime of managed trade (the Hushi system), and both Japanese and Chinese governments recognized the utility of bilateral trade relationships, communicated through 'silent diplomacy' (Iwai 2010, 2012; Hao 2015).

By contrast, Indian Ocean trade was fostered by multi-layered networks of merchants, characterized by openness, spanning ecologically diverse areas, and with relatively large long-distance trade components. Territorial boundaries were observed, but the rules of exchange were not as imposing as in Europe, especially in sea. Europeans, Arab traders and local merchants overlapped in their operations, and they were not necessarily structured in a hierarchical way. The Mughal Empire was a strong fiscal military state, at least at its peak, but was relatively flexible towards trade, including maritime trade. In the Indian Ocean commodities from all over the world were exchanged as a result. Composition of commodities traded in the Atlantic or East Asia was not as comprehensive as that of the Indian Ocean (Chaudhuri 1990; Riello and Roy 2009).

\subsubsection{The Emergence of an Asian International Division of Labour}

In 1820, China's share in Asia's GDP was 59\% and South Asia 29\%, while Japan, South Korea, Taiwan and Hong Kong (using later territorial categories for the sake of comparison) took up 7\% and Southeast Asia 5\% (Asia's GDP was calculated as the sum of GDP of four sub-regions). By 1950, China' share declined to $28 \%$, while that of Japan and others rose to $21 \%$, Southeast Asia to $17 \%$ and South Asia to $33 \%$. Thus the four sub-regions became much more equal in terms of economic weight, though not of the size of the population. Within China and India economic progress mainly came from the coastal regions. The gravity of Asia's GDP shifted from the two agrarian empires in China and India to maritime monsoon Asia.

The key to this transformation was locational advantage. Economies of maritime monsoon Asia absorbed Western technology and institutions on the one hand, and mobilized local and regional resources on the other, through the development of 
transport networks, trade and migration. Two paths emerged as a result. In Meiji Japan, and a little later in coastal China, commercial ports in or near major cities, such as Yokohama, Kobe and Shanghai, connected imported and local resources, to help modern cities and industries grow. It was important that the emerging area had both the will to industrialize (thus committed to import technology and build an infrastructure to absorb it) and the social capacity to mobilize local resources, natural and human (including the ability to import or recruit them from other places). At the same time, in India and Southeast Asia, commercial ports, built by Western colonial powers, also connected imported and local resources to develop economies centred on port cities, but driven by the exports of primary products. They included Bombay, Madras, Calcutta, Singapore, and Jakarta. Hong Kong acted as a colonial port serving both for China and Southeast Asia.

The two paths were inter-related, and were not necessarily geographically separate: In fact the first modern industry emerged in Bombay in the middle of the nineteenth century, and soon met competition from Japan. Both China and Japan exported tea and raw silk in large quantities to earn foreign exchange. Commercial ports in Korea and Taiwan were developed by Japanese colonial authorities, to connect their primary exports to Japan. But there was also a divergence within maritime parts of modern Asia. South and Southeast Asia tended towards the path of primary producer economies, while East Asia tended towards industrialization.

Japan's labour-intensive industrialization was dependent on this growth of maritime economies, as well as being a major driver of it. In the early stage Japan exported rice and coal, but soon became an importer of these commodities as well as raw cotton and sugar. She competed with India in the market of cotton yarn in central China during the 1890s. By the early twentieth century she imported raw cotton from India, rice and sugar from Southeast Asia, Korea and Taiwan, and soybeans and their products from Manchuria, and exported labour-intensive manufactured goods such as cotton yarn cotton cloth and sundries to other parts of Asia. The environmental implication of this division of labour was a mitigation of local resource constraints, which enabled Japan to expand her industrial base, especially cotton textile industry. In this respect the basic logic was similar to England's discovery of 'ghost acreage' in North America during the period of the industrial revolution (see Pomeranz 2000, 274-278).

In the interwar period China went through import-substitution industrialization, which urged Japanese manufacturers to find more processed or higher-value added products for exports. Under the regime of selective protectionism, Japanese manufacturers also increased the exports of textile machinery to China, which started regional industrialization. This was an original 'flying geese' (Akamatsu 1962), which has become a basic mechanism of progressively including higher value-added commodities and commodities made with the more advanced technology in intra-regional trade. Japan adopted a policy of selective protectionism, that is, setting up tariff barriers only against imports directly competing with the domestic industry attempting import-substitution but pursuing the benefit of free trade, as a result of which her overall tariff rate stayed relatively low, while China and India raised tariff rates, partly for revenue purposes but also to more comprehensively protect domestic industries. 
Japan's dependence for the imports of raw materials was much greater than that of the other two countries.

Countries involved in intra-Asian trade included a number of European colonies in South and Southeast Asia, as well as countries of East and Southeast Asia under unequal treaties and the treaty port system. Under this system of 'forced free trade', Japanese merchants brought a wide range of cotton manufacture (cloth and apparel) and sundries (matches, soap, toothpaste and tooth brushes, traditional medicine, umbrellas, bicycles and noodle-making machines) to Asian peoples, and they interacted with Indian, Chinese and other Asian merchant networks. It was these networks, together with the Japanese trade associations (and government efforts to help them to compete with Asian networks), that facilitated the exports of labour-intensive manufactured goods. With a time lag and a series of heavy political disturbances, labour-intensive industrialization spread to China and eventually to other parts of Asia.

In Southeast Asia the crucial moment came in the late nineteenth to the first half of the twentieth centuries when modern maritime (mostly colonial) states seriously began to interact with populous Asian states, which proceeded with industrialization. Under the Western impact, the fusion between the two created massive migration of Indian and Chinese labourers to Southeast Asia, the growth of intra-Asian trade between Southeast Asian primary producers and other Asian producers of manufactured goods, and above all the sense of sharing of modern consumption goods among the ordinary Asian peoples (from rice, dried fish, spices and a range of nontimber forest products to cotton cloth and sundries mentioned above). The traditional commodity complex shared in the region (rice, sugar, tea, silk and cotton) remained important, but a modern Asian international consumer culture emerged through intra-Asian trade and labour-intensive industrialization. This in turn made it easier to transfer labour-intensive technology and managerial know-how, and prepared for regionally-driven industrialization in the post-war period.

\subsection{The Post-war Industrialization and the Developmental State}

\subsubsection{Open Regionalism Under the Developmental State}

The government in the inter-state system, which attempts to maximize the interest of its people, could act against the principle of free trade, which seeks mutual gain. In post-war Asia, there was a greater sense of tension between the need for political and economic independence and intra-regional trade than pre-war. On the one hand, independence meant gaining a political and economic autonomy, especially in relation to the former colonial power, and more generally to advanced Western countries. At the same time, the pre-war path dependency suggested that there was room for newly independent countries to take advantage of regional commercial networks, 
especially through the entrepots of Hong Kong and Singapore. In this section, we discuss how the states reacted to the issue of economic integration through trade, and eventually most of them came to engage in intra-regional trade and competitive regional industrialization.

The strategy for the 'import substitution industrialization', strictly interpreted, meant the building of a full industrial structure equivalent to that in developed countries, by imposing very high tariff against imports of industrial goods from the West. This strategy seemed politically viable in many countries, including India and China, though it turned out to be relatively short-lived. In India, by the Third Five Year Plan period, it became clear that benefits of heavy industrialization (modelled largely on the Soviet experience) were not being 'trickled down', resulting in 'disguised unemployment' in the rural area and the growth of the urban 'informal sector'. In communist China (during the Mao period), human development indicators (such as education and health) improved faster than in the more democratic India, but the country also struggled to develop competitive heavy industries (also originally influenced by the Soviet experience) in the absence of technological transfer from the more developed countries, especially from the West.

By contrast, some East and Southeast Asian countries, such as Japan, NIEs (Newly Developing Economies of South Korea, Taiwan, Hong Kong and Singapore, which had relatively high initial conditions of various kinds) and ASEAN 4 (Thailand, Malaysia, Indonesia and the Philippines, which pursued the export-oriented path to industrialization) successively experienced relatively high rates of growth, by taking advantage of the gains from trade more than India and China.

South Korea and Taiwan were among the first that captured the concept of exportorientation in industrialization, partly because they were too small a country for developing a comprehensive industrial structure, and partly because they lacked the natural resources (especially mineral and energy) needed for economic growth in much the same way as Japan did. In both cases political autonomy was complicated as much by territorial relations (with North Korea and China) as by dependence on exports, while Japan's was conditioned by the defeat of the war. It was important that these countries nevertheless pursued a policy for export promotion and were able to link it to both resource imports and employment creation.

ASEAN 4 started a developmental policy under the authoritarian regime around 1965. They gradually turned to the export-oriented strategy, coined by Hla Myint in an ADB-sponsored conference in 1970, and proceeded with a full route to industrialization in the 1980s (This can be seen in the radical change in their commodity composition of trade). In spite of the criticism of 'shallowness' of industrialization (Singh 1979) and the lack of initial conditions (such as the land reform) taken for granted in East Asia (Lee 1979), they pursued the export-oriented industrialization strategy with varying degrees of success. It became a mainstay of growth Asia's economic policy. Neither the U.S., the key provider of political and military support, nor former colonial powers (European states and Japan), has been primarily responsible for the diffusion of this strategy. If anything, it grew out of what was happening on the ground, rather than as a result of economic principles or policy directives from above. Even so, it was vital for some ideas and policies to be articulated and pursued. 
The 'open regionalism', which does not discriminate against countries outside the region when regional integration takes place and tariff rates are reduced inside the region (that is, this strategy proposes to reduce tariff rates against outside one-sidedly), derives from a special type of economic nationalism, which is different from both the hegemonic regime of free trade (as per Britain and the U.S.A.) and Continental European style regime of free trade through treaty networks (Sugihara 2015). Historically, the region was used to low tariff level exposure to the international economy, especially in the late nineteenth and early twentieth centuries under the regime of 'forced free trade'. It was natural for these Asian countries to engage in trade between neighbouring countries with similar economic structure and to compete for similar markets, in order to seek complementarity for small gains from trade and exploit regional potentialities for growth. Trade was seen, not just as a policy tool for economic growth or industrialization, but as a prime mover in itself. India and China, which had been an agrarian empire in the early modern period and opted for strict import-substitution industrialization in the post-war period, were slow to join this regional dynamics. Nevertheless, their long-term trajectories were not necessarily of agrarian origin. Both countries had long traditions of engaging in regional trade.

After the policy changes in 1979 and in 1991, China and India joined the network of trade and economic growth, and in many ways led the dynamism. China retained a high rate of growth for more than three decades, only with minor downturns, and increasingly traded with other Asian countries. Although the impact of foreign investment in China (from U.S., E.U. and Japan as well as from overseas Chinese capital) was significant as a vehicle of technology transfer and the training of labour, the increased significance of intra-Asian trade cannot be accounted for by such investment flows alone. Along with the growth of production networks initiated by multinational companies spanning greater Asian regions, the amount of smaller, local and regional transactions between China and Southeast Asia and other neighbouring countries increased in parallel to them. As a result, Asia's share in Chinese trade continued to grow. It was China that sustained the growth of commercial linkages among Asian countries in the more recent years, in many ways replacing the role Japan (and NIEs) had played earlier.

By 2000 India was trading eastwards (mainly with growth Asia and the U.S.) more than westwards (mainly with E.U., Russia and the Middle East). In 2015 she became the fastest growing country among the main emerging states, rapidly becoming part of Asia's regional growth. It is clear by now that 'growth Asia' began to include the 'hinterland', as well as smaller countries of Asia. By making a vast rural population closer to trade-inspired industrialization, the policy changes in China and India had a major impact on the rise of emerging economies in particular and global economic development in general.

China today is trying to distance itself from the norms and institutions that have governed the original Asia-Pacific economy, which was created in the 1950s to the 1970s by the United States, Japan, ASEAN and Australia. They include U.S. hegemony in military and international relations, as well as rules of international trade and monetary systems. The crucial question, however, is whether these moves 
will affect the forces promoting intra-regional trade. So far China appears to want to use them, so long as they do not contradict with its political and territorial interests.

\subsubsection{Labour-Intensive Industrialization and the Improvements of the Quality of Labour}

In 1954 Arthur Lewis wrote "Economic Development with Unlimited Supplies of Labour", in which he characterized labour in developing countries as abundant, homogenous and disposable, and described Asian labour in the 1880s as a powerful force of international labour market "willing to go to the ends of the earth for a shilling a day" (Lewis 1954, 1978). This was a polarization story, in which highwage economies in the West and low-wage economies in the non-European world grew simultaneously without a 'convergence'.

Instead, post-war growth Asia saw a steady improvement of the quality of labour, best seen in the progress of education, but also obvious in the type of industries which developing Asia has successfully established, especially in industrial clusters with a range of machinery industries. In manufacturing industry growth Asia substantially 'caught up' with the West. The main explanation for labour-intensive industrialization rests on the comparative advantage of an industrializing economy, that is, if labour is abundant and capital (and land) are scarce but the economy has a social capacity to industrialize, it tends to develop a set of technology and institutions that use more labour and less capital. In practice, major differences between East Asia and Western Europe came from the degree and speed of urbanization, which is relatively capital-intensive. Differences also came from the type of industries: (relatively capital-intensive) machine spinning diffused faster in the West, while the survival and development of (relatively labour-intensive) hand-weaving industries was more visible in East Asia. But at root there was the question of availability of labour of a good quality. Labour-intensive industrialization needed competitive and adaptable labour, which enabled industries to grow into a technology-inducing and institution-developing mode.

How did Asia acquire such labour? Elsewhere I have argued that there was an 'industrious revolution' in East Asia in the early modern period. Labour-intensive technology and labour-absorbing institutions developed to increase land productivity, and enabled the peasant household to combine rice farming, commercial agriculture and proto-industry. General, managerial and inter-personal skills (as against specialized, technical and individual ones) were formed. In Japan (and later in China) industrial workforce did not come from the proletariat but came from the peasant household. Early workers of peasant origin (including many young girls) were largely illiterate, but many of them were disciplined to become a labour of a good quality after they were transferred to modern factory. In Meiji Japan the real wage was low compared to that in the West, and working conditions were often harsh. One factor 
that made Japanese labour-intensive industries competitive was the high quality of labour relative to the wage (Sugihara 2013b).

Not all countries had as high initial conditions as Japan. Beginning in Japanese mills in China and India from the end of the nineteenth century onwards, we hear frequent complaints of Japanese factory managers about the quality of non-Japanese labour, often with culturally biased languages. The more rigorous observations and studies found differences in the rates of absenteeism, the response to incentive schemes and the degree of commitment to work in different places and in different periods. Nevertheless, a general trend is clear: As industrialization proceeded, a much larger proportion of labour became educated and/or skilled, while cheap labour in harsh working conditions remain in developing countries. Income inequality increased, though not always sharply, as expected in the Kuznets curve. But the speed of development of manufacturing industries was so rapid that the average manufacturing wage went up.

We briefly record evidence of the regional dimension of industrial upgrading. Between 1972 and 1985 'new' high technology industries grew faster in Asia than in the U.S.A. and Western Europe, although the original technology (mainly computer and communication technology) substantially came from the United States (Table 3.3). The ILO studies in labour-intensive industries and human resource development extensively discussed the 'matching' between the nature of new demand for skills on the one hand, and education and formal training on the other (Amjad 1981, 1987). Not many attempts were successful, nor were they comprehensively pursued by the government, but by the 1980s the direction of thinking was clearly towards the development of human capital, or in manufacturing, workforce of a good quality. This was linked to the shift towards a more balanced allocation of educational expenditure between primary, secondary and tertiary sectors [Many developing countries in Asia overspent on tertiary education, while spending too little on primary education at the early stage of industrialization. See Lindert (2003, 2004)]. An overall result was a simultaneous rise of per capita GDP and the Human Development Index (Table 3.4).

This is now history, and we face the 'middle income trap' today. My first observation is that the dynamics of intra-Asian trade and technology and managerial transfers at the level of labour-intensive industries (therefore to some extent at the level of related tertiary industries) remain at work. In terms of trade-driven growth, Asia is one of the best hopes among the emerging economies, largely as a result of alternating growth spurts in Southeast Asia, China and India and a high degree of regional integration.

My second observation is that stagnation of developed countries can be a cause of trap or a source of growth. From 1931 to 1936 Japan grew faster than most Western countries, and proceeded with heavy industrialization. This partly came from the 'import-substitution industrialization', in the sense that a competitive pressure from the West was eased (largely as a result of the Great Depression and the devaluation of the yen) and many domestic machinery sectors developed. The intra-Yen bloc trade now included a significant proportion of machinery trade. But it was also a move towards a 'relative autonomy', echoing post-war India and China, in that 
Table 3.3 Trends of domestic demand in volume terms by branch of industry in the european community, the United States and Japan (average annual growth rate, 1972-85) (\%)

\begin{tabular}{l|r|r|r}
\hline & EC & U.S.A. & \multicolumn{1}{l}{ Japan } \\
\hline Strong-demand sectors & $\mathbf{5 . 0}$ & $\mathbf{5 . 2}$ & $\mathbf{1 4 . 3}$ \\
\hline Office machines, data-processing equipment & 9.0 & 6.5 & 7.2 \\
\hline Electrical and electronic equipment and supplies & 3.5 & 7.2 & 20.7 \\
\hline Chemicals and pharmaceuticals & 5.3 & 2.3 & 9.9 \\
\hline Moderate-demand sectors & $\mathbf{1 . 2}$ & $\mathbf{2 . 8}$ & $\mathbf{3 . 1}$ \\
\hline Rubber, plastics & 2.8 & 5.4 & 2.0 \\
\hline Transport equipment & 1.7 & 2.7 & 5.2 \\
\hline Foodstuffs, beverages, tobacco & 1.2 & 0.4 & 0.0 \\
\hline Paper, printing & 1.6 & 2.9 & 2.7 \\
\hline Industrial and agricultural machinery & -0.1 & 5.6 & 5.6 \\
\hline Weak-demand sectors & $\mathbf{- 0 . 3}$ & $\mathbf{0 . 5}$ & $\mathbf{2 . 4}$ \\
\hline Metal products & -0.5 & -0.4 & 3.4 \\
\hline Miscellaneous industrial products & -0.6 & 2.1 & 1.9 \\
\hline Ores and ferrous and non-ferrous metals & 0.6 & -1.8 & 2.0 \\
\hline Textiles, leather, clothing & -0.2 & 2.0 & 2.2 \\
\hline Non-metallic minerals (construction materials) & 0.1 & 1.7 & 1.1 \\
\hline
\end{tabular}

Sources and notes van Liemt $(1992,12)$. Data derive from Commission of the European Communities, International Trade of the European Community: A View of Certain Aspects of the External Trade of the Community, Directorate-General for Economic and Financial Affairs, European Economy, No. 39, Brussels 1989

Table 3.4 Human development index, 1960-1995

\begin{tabular}{l|l|l|l|l}
\hline & 1960 & 1970 & 1980 & 1995 \\
\hline U.S.A. & 0.865 & 0.881 & 0.905 & 0.943 \\
\hline Japan & 0.686 & 0.875 & 0.906 & 0.940 \\
\hline Hong Kong & 0.561 & 0.737 & 0.830 & 0.909 \\
\hline Singapore & 0.519 & 0.682 & 0.780 & 0.896 \\
\hline South Korea & 0.398 & 0.523 & 0.666 & 0.894 \\
\hline Thailand & 0.373 & 0.465 & 0.551 & 0.838 \\
\hline Malaysia & 0.330 & 0.471 & 0.687 & 0.834 \\
\hline Indonesia & 0.223 & 0.306 & 0.418 & 0.679 \\
\hline Philippines & 0.419 & 0.489 & 0.557 & 0.677 \\
\hline China & 0.248 & 0.372 & 0.475 & 0.650 \\
\hline India & 0.206 & 0.254 & 0.296 & 0.451 \\
\hline
\end{tabular}

Source UNDP, Human Development Report (1996) 
most new industries were linked to the research and development efforts relating to Japan's military industries and territorial expansion (Sawai 2012). If the direction of industrial development was driven by political and military interests (and in Japan's case without a full understanding of global military and resource balances), there was no guarantee, or even a prospect, that the country was adopting a sensible importsubstitution strategy based on factor-endowment considerations.

\subsubsection{Capital-and Resource-Intensive Industrialization and the Improvements of Physical Infrastructure}

To some extent rapid industrial upgrading in Japan along the lines of labour-intensive industrialization was complementary to the more capital- and resource-intensive industries, especially in the U.S. But it also resulted in the upgrading and expansion of capital- and resource-intensive industries within Asia. Imports of fossil fuels, including oil and liquefied natural gas (LNG), and other raw materials became essential for this purpose.

In the 1950s there was a debate over how Japan's resources should be secured, especially as to whether its energy demand should depend on domestic coal or on imported oil. High economic growth and rapidly rising demand favoured the latter option. There was also a coordinated attempt by Ministry of International Trade and Industry (MITI) to spread the energy-saving methods of production in steel and electrical machinery industries. In the second half of the 1950s serious attempts were made to develop a 'seafront industrial complex (rinkai kogyo chitai)' to serve for oil refinery, petrochemical industry and electricity generation industry among others (see Fig. 3.2). There was an accumulation of knowhow prior to this period, including the idea of establishing the 'industrial port' as distinct from the 'commercial port'. International circumstances also strongly favoured this strategy. A sudden expansion of oil production in the Middle East was not being met by the matching increase of demand in Europe, and majors were looking for their customers. This gave Japanese companies the opportunity to negotiate with Western firms on technology transfer on good terms (Kobori 2010).

Pursuit for the seafront complex involved a number of industrial and infrastructural developments. Against the background of low prices of resources and energy, Japanese shipbuilding companies and shipping lines attempted to utilize the latest technology of large oil tankers and other specialist bulk vessels (e.g. for iron ore) to the full. Equally important was a rapid introduction of container cargoes for other commodities, which standardized shipments across international ports, and helped coordinate the transfer of goods between different means of transport in industrial ports. The seafront complex was constructed with dredging and reclamation, centered on a deep habour which could take large vessels. Railway lines and roads were built to ensure access. The establishment of the industrial site required pursuit of the economies of scale on the one hand, and political and public approval on the other. In 


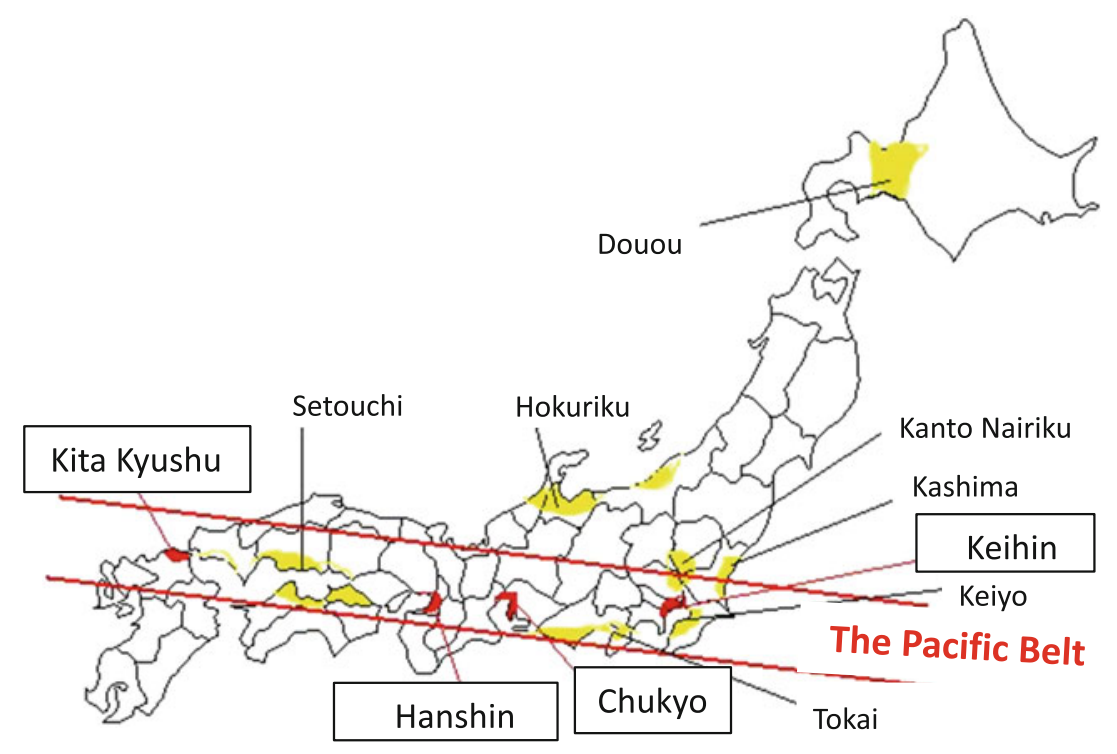

Fig. 3.2 The industrial belt in the Japanese Pacific Coast Source and note Adapted from http:// hiroseki.sakura.ne.jp/industry.html

the 1960s the Japanese political will was strong enough to push the 'Pacific industrial belt' development at a speed inconceivable in the established industrial districts in the West.

The industrial complex was typically located not in the central parts of major cities such as Tokyo and Osaka, but in neighbouring areas. For example, Tokyo retained employment-absorbing labour-intensive (by then mostly skill-intensive) industries within the central wards, while the bay areas of Yokohama became home to the resource-intensive cluster. After the second half of the 1960s environmental protection movements began to spread, and the municipal government absorbed the voice of the citizens before the central government did. Such politico-social dynamics partially resulted in the diffusion of the industrial complex to the more distant and less politically sensitive or powerful areas, without necessarily mitigating the potential environmental damages (Kobori 2017).

In prewar Japan rural industrialization remained important, especially in labourintensive industries, while agriculture provided industry with labour force, purchasing power and food and raw materials. Traditional considerations for industrial locations included local employment with relatively low wages (e.g. female byemployment in the peasant household economy), and supply of water, food and energy (both biomass and electricity). All of these functions had to be reorganized under the post-war national land development policy.

Unlike the 'global supply chain', which in this context essentially consists of a network of factories (plus perhaps headquarters) scattered in various parts of Asia, 
the key feature here is what might be called the 'resource nexus', the creation of an international competitive spatial cluster designed for combining specific sets of resources. In particular, local and domestic resources was to be efficiently combined with import resources. As industrialization proceeded, the resource nexus began to reorganize the entire spatial allocation of human and natural resources of the country. It encouraged the growth of cities, which provided resource-intensive industries with labour and the market (e.g. for electricity). A large proportion of population moved to cities, while a large part of rural areas became 'urban' at the same time. A new relationship between the city and the countryside was formed, with the premise that industries would have access to global resources to lead economic growth.

Other East Asian countries also adopted the seafront industrial complex strategy. In South Korea initial conditions for heavy and chemical industries were low, because most of the colonial legacy was located in the North. In 1973 the developmental state declared the programme for 'heavy and chemical industrialization', and a series of seafront complex were established at far south. They were distinctly separate from the traditional light industry zones. The new nexus included shipbuilding, automobile, steel and military-related machinery industries. In addition to the steel industry, which grew out of domestic demand and joined this development, petrochemical and shipbuilding industries were especially successful in exports. Meanwhile, in Seoul and its neighbouring regions and some other clusters, labour-intensive industries were transformed into the 'new' ones driven by the microelectronics revolution (Hashiya 1995, 43-46, 49-53; Ishizaki 1996, 65-86).

In Taiwan where traditionally fragmented small and medium-sized businesses were scattered across the island, the government-led strategy for heavy and chemical industrialization lasted for a relatively short period, from the late 1960s to the early 1970s. Even so, steel, petrochemical and shipbuilding industries were established, and they played a supporting role for the growth of labour-intensive and high-technology industries (Wade 1990, 86-112; Hashiya 1995, 46-49; Sato 1996, 96-101).

In China, the initial phase after the policy reform of 1979 saw a slow and difficult process of transition. Many heavy industries were located inland for political and strategic reasons and with the ideology that they should be developed close to where coal and other resources were found. Experts had to be persuaded that imports of resources were essential for further industrialization. The Pearl River delta, on the strength of the rich historical tradition of Hong Kong as a major trading hub and the export-zone initiatives in Canton in the 1970s, led the development of electronics industries, while the city of Shanghai (and the Yangtze River delta) initially suffered from the need to reorganize state-owned enterprises, heavy industries and coal mines, to cope with international competition. The establishment of Shanghai Baoshan Ironworks with the introduction of foreign (Japanese) technology and management was a turning point in China's commitment to the seafront development model. By the 1990s the Yangtze River delta reestablished itself as the main industrial complex with large imports of resources from abroad (Zhou 2007, 81-84, 119-121).

Here the linkage between the 'new' electronics-related industries and resourceintensive industries took a different form. Three 'megalopolis', a chain of connected 
metropolitan areas, located in Pearl River delta, Yangtze River delta and the national capital region (Beijing-Tianjin-Hebei) respectively, embraced megacity (or cities), the smaller cities and rural areas with township enterprises, and grew into a center of progressively larger urban networks. While heavy and chemical industries, especially steel and petrochemical sectors, were concentrated on the seafront to maximize the benefits from the economies of scale and access to imports, electronics and machinery industries were located across a variety of cities and countryside, so that the region could create intra-industry linkages and links to a large consumer market (Zhou 2007, 72-128). This was a more embracing model for combining the strength of natural and human resources than the earlier experiments in Japan and elsewhere, with accompanying, often more serious, problems such as air pollution. It also had equally powerful political and social consequences on the inequality and uneven resource allocation with other parts of China.

\subsection{Dealing with Local Resource Constraints}

In this section I wish to discuss the assumptions implicitly made for the discussion on intra-regional trade and industrialization by introducing the importance of nontradable resources, and the extent to which they affect the developmental state and the long-term path of economic development.

Up to around 1800, population growth did not cause major problems of environmental sustainability, in that nature was governed by forces of the geosphere (in which energy and material flows are determined by natural processes) or the biosphere (in which the eco-system and food chains function by incorporating human interventions rather than vice versa). Humans depended for their food on their own labour on arable land, and Malthusian or Boserupean dynamics were at work. Meanwhile, they depended for their energy on (mainly forest-derived) biomass, as well as on human and animal muscles, water and wind. Burning biomass was the basic technology for heating and lighting, as well as for clearing the land. But energy consumption per capita increased very slowly, while population growth was yet to reach the point of exhausting the land frontier in most parts of the world.

In the age of fossil-fuel-based industrialization and growth of world trade, local constraints were broken. Instead, securing raw materials from abroad became important, in order to extend the industrial capacity of the nation beyond the framework set by local resource constraints. Britain and Japan would not have been able to industrialize in the way they did, without imports of raw materials such as raw cotton and food. In the post-war period of economic growth in Asia, the regime of free trade became a vital element in overcoming the local resource constraints for the same reason, especially for relatively small economies, including many emerging ones.

At the same time, while food and fossil fuels could be imported relatively easily if the country earns foreign change through exports, the resulting growth put less tradable factors of production under unprecedented pressure. The most obvious such resources include water for agricultural use and local biomass energy. 
In fact, securing all essential resources for production and livelihood has been a twin target for the welfare of the local society for most of human history. If large parts of Asia, especially China and India, held an unusually large population in 1820, and exhibited a rapid expansion in absolute numbers during the last half century, it implies that these societies found answers to meet this target, especially in the early modern and the most recent periods.

Historians of the colonial period have discussed the more stagnant trends dividing these two periods, by relating famines, epidemics, disasters and wars to colonialism and/or the failure to secure resources for the local population. Economic and social historians have discussed the prevalence of poverty, social inequality and instability in the last two centuries, often by linking them to the resource shortage, especially that of land. Malthusian and neo-Malthusian thinkers have considered these issues in the context of population control. They have left unanswered the question of why population nevertheless grew so much in the long run.

The best-known approach to this question is to discuss the environmental characteristics of monsoon Asia. In describing post-war economic development up to c. 1980, Harry Oshima stressed the common socio-environmental characteristics of monsoon Asia, stretching from East and Southeast Asia to South Asia, in terms of seasonal rainfall patterns induced by monsoon winds, and the centrality of the large delta for the growth of rice farming and dense population. His formulation stresses the sequence of intensive rice farming, population growth, availability of cheap labour and labour-intensive industrialization leading to economic growth (Oshima 1987). This sequence has been further studied, especially with reference to East Asia. The development of intensive farming implied the availability of water and manure required for commercial crop production (Elvin and Ts'ui-jung 1998); Population growth required the maintenance of social order (Wong 1997); Labourintensive industrialization implied the capacity to trade primary products or labourintensive manufactured goods for capital-intensive and high-technology goods (Sugihara 2013b). On South Asia, difficulties of securing water delayed the rise of agricultural (land) productivity, which was eventually responded to by the green revolution and the introduction of tube wells (Roy 2006, 2007). This innovation made it possible for farmers to grow water-intensive, as well as labour- and land-intensive crops, and to provide the basis for full-fledged industrialization. The issue is how this sequence occurred in some parts of Asia to create a path and at what speed, while it did not in the other parts (or in comparably developed parts of Africa).

I suggest that, as far as monsoon Asia is concerned, three natural resource endowments, land, water and energy, have been important for both livelihood security and resource security. The usual factor endowment perspective singles out land and discusses its relationships with labour and capital. If land is scarce relative to labour, labour absorption is likely to be encouraged, and labour-intensive technology and labour-absorbing institutions are likely to develop. If land is abundant, such a path is less likely to be followed. Such a perspective ignores the crucial importance of water and (biomass) energy as local resource endowments. Major constraints to land use could be water or prevalence of infectious diseases, as a result of which people would not work on the land or raise the cattle. Seasonal and annual variability of 
water supply could be crucial for the stability of agriculture. Nearby forests or the 'waste land' from which timber, twigs or crop residues had been obtained, could disappear, as a result of population increase and expansion of arable land, and this could make it difficult for the peasant household to secure biomass energy for cooking, lighting and heating, and for the local economy to secure biomass resources for fuels and building materials (Sugihara 2012: 176-179). In other words, there was a great deal of environmental diversity, which worked for sustaining a large population in monsoon Asia since the early modern period, but, as industrialization occurred and tradable resources were brought in, some areas such as the Pacific coast or port cities and their environs along the Indian Ocean prospered, while hinterlands, semi-arid regions and mountainous areas took longer to meet the increased demand for local resources.

In many parts of contemporary China, water became scarce, and emerged as focal point of local, national and regional politics (Pomeranz 2009). The problem was aggravated by the need for dam construction for electricity generation. In contemporary India, a rapid progress in the use of tube well solved the issue of self-sufficiency of food and raised agricultural productivity, but resulted in the lowering of water tables. Free electricity for tube well users also distorts resource allocation, for example by making the improvement of electricity supply more difficult than otherwise (Shar 2009). Where electricity is not always available, securing local biomass energy for cooking and heating purposes could still be a matter of life and death. Vast number of hours was spent for water and fuel wood collection, mainly by women (Sugihara 2017).

Thus we consider a stable mix of land, water and energy as a resource security measure, and what might be called the 'water-food-energy nexus' as a livelihood security measure. The two measures are related to each other in a number of ways. The stable mix would provide a necessary, if not sufficient, condition for the livelihood nexus. In turn, the higher the livelihood security, the better the quality of labour and the quality of care would become. Under globalization the international competitiveness of the local society depends increasingly on these factors, rather than on abundant and disposable cheap labour. The combined strength of livelihood security and resource security would underscore the capacity of the developmental state. Its lack would imply the less favourable outcome.

\subsection{Concluding Remarks}

Components of regional integration discussed above were mainly economic. Compared to politically charged integration in Europe, Asia's regional integration was more strongly driven by trade and other economic factors. Part of the role of the state was carried out by commercial networks and by the local community. Even so, Asian states played a central role in regional integration by becoming the 'developmental state', that is by embracing 'developmentalism', in which economic development is a main policy goal. This was mostly clearly expressed in its effort to establish physi- 
cal infrastructure to access global resources. Elsewhere I have argued that the Asian norm has become 'developmentalism of free trade', that is, 'free trade if possible, state intervention if necessary' [Sugihara (2013a): for 'imperialism of free trade', see Gallagher and Robinson (1953)].

This ideology was a natural outcome of the Asian development path, which was built on the rich experience of the exploitation of socio-environmental characteristics of Monsoon Asia. At the same time, developmentalism must be sustainable both economically and environmentally, and at national, regional and global levels. Because Asia's growth rates remain comparatively high, the region has become a 'hot spot' of environmental problems. Moreover, by importing vast amounts of resources from outside the region, Asia is putting pressure on global environmental sustainability. Nevertheless, its capacity to generate intra-regional trade and the dynamics of technology and managerial transfer remains the best hope for sustainable economic development on a global scale. Politicians and bureaucrats should acknowledge the historical depth of the Asian path, and take advantage of it.

\section{References}

Akamatsu, K. (1962). A historical pattern of economic growth in developing countries. Developing Economies, Preliminary Issue, 1, 3-25.

Amjad, R. (1981). The development of labour intensive industries in ASEAN countries: An overview. In Amjad (Ed.), The development of labour intensive industries in ASEAN countries (pp. 1-28). Geneva: ILO.

Amjad, R. (1987). Human resource development: The Asian experience in employment and manpower planning: An overview. In Amjad (Ed.), Human resource planning: The Asian experience (pp. 1-37). Geneva: ILO.

Arpan, J. S., Barry, M., \& Van Tho, T. (1984). The textile complex in the Asia-Pacific region: The patterns and textures of competition and the shape of things to come. Research in International Business and Finance, 4(B), 101-164.

Baker, C., \& Phongpaichit, P. (2017). A history of Ayutthaya: Siam in the early modern world. Cambridge: Cambridge University Press.

Chaudhuri, K. N. (1990). Asia before Europe: Economy and civilisation in the Indian Ocean from the Rise of Islam to 1750. Cambridge: Cambridge University Press.

Elvin, M., \& Ts'ui-jung, L. (1998). Sediments of time: Environment and society in Chinese history. Cambridge: Cambridge University Press.

Gallagher, J., \& Robinson, R. (1953). Imperialism of free trade. Economic History Review, 6-1, $1-15$.

Hao, P. (2015). Kinsei Nisshin Tsusho Kankeishi [A history of Sino-Japanese trade relations in the early modern period]. Tokyo: Tokyo Daigaku Shuppankai.

Hashiya, H. (1995). Kankoku, Taiwan no NIEs-ka to Toshika [Development of newly industrializing economies and urbanization in South Korea and taiwan]. In R. Kojima \& N. Hataya (Eds.), Hatten Tojokoku no Toshika to Hinkonso [Urbanization and the poor in developing countries] (pp. 41-68). Tokyo: Ajia Keizai Kenkyusho.

Ishizaki, N. (1996). Kankoku no Jukagaku Kogyo Seisaku: Kaishi no Naigai Joken to Jisshi Shutai [South Korea's policy for heavy and chemical industries: Internal and external conditions for its establishment and actors for implementation]. In T. Hattori \& Y. Sato (Eds.), Kankoku, Taiwan no Hatten Mekanizumu [Patterns of development of South Korea and Taiwan] (pp. 65-86). Tokyo: Ajia Keizai Kenkyusho. 
Iwai, S. (2010). Choko to Goshi (Chaogong and Hushi). In H. Wada et al. (Eds.), Higashi Ajia Kingendai Tsushi 1 Higashi Ajia Sekai no Kindai: 19 Seiki [Modern and contemporary history of East Asia, Vol. 1, The modern period of the East Asian World: The 19th Century, pp. 134-153]. Tokyo: Iwanami Shoten.

Iwai, S. (2012). International society after "The transformation from Civilized to Barbarian”. (J. A. Fogel Trans.), Sino-Japanese Studies, 19(1), 1-22.

Kobori, S. (2010). Nihon no Enerugi Kakumei: Shigen Shokoku no Kingendai [The energy revolution in Japan: The modern and contemporary history of a resource-poor country]. Nagoya: Nagoya Daigaku Shuppankai.

Kobori, S. (2017). Rinkai Kaihatsu, Kogai Taisaku, Shizen Hogo: Kodo Seicho-ki Yokohama no Kankyoshi [Seafront development, anti-pollution policy and nature conservation: An environmental history of Yokohama in the period of high-speed growth]. In S. Shoji (Ed.), Sengo Nihon no Kaihatsu to Minshushugi: Chiiki ni Miru Sokoku [Development and democracy in post-war Japan: Conflicts at local settings] (pp. 71-104). Kyoto: Showado.

Lee, E. (1979). Egalitarian peasant farming and rural development: The case of South Korea. World Development, 7(4/5), 493-517.

Lewis, W. A. (1952). World production, prices, and trade, 1870-1960. Manchester School, 20(2), 105-138.

Lewis, W. A. (1954). Economic development with unlimited supplies of labour. Manchester School, 22(2), 139-191.

Lewis, W. A. (1978). Growth and fluctuations, 1870-1913. London: George Allen and Unwin.

Li, B. (1998). Agricultural development in Jiangnan, 1620-1850. Basingstoke: Macmillan.

Lieberman, V. (2003). Strange parallels: Southeast Asia in global context, c. 800-1830, Vol. 1 Integration on the Mainland. Cambridge: Cambridge University Press.

Lindert, P. H. (2003). Voice and growth: Was Churchill right? Journal of Economic History, 63(2), 315-350.

Lindert, P. H. (2004). Growing public: Social spending and economic growth, The Story (Vol. 1). Cambridge: Cambridge University Press.

Oshima, H. (1987). Economic development in Monsoon Asia: A comparative study. Tokyo: University of Tokyo Press.

Pomeranz, K. (2000). The great divergence: China, Europe, and the making of the modern world economy. Princeton: Princeton University Press.

Pomeranz, K. (2009). The Great Himalayan Watershed: Agrarian crisis, mega-dams and the environment. New Left Review, 58, 5-39.

Reid, A. (1993). Expansion and crisis: Southeast Asia in the age of commerce 1450-1680. New Haven: Yale University Press.

Riello, G., \& Roy, T. (Eds.), with the collaboration of Prakash, O., \& Sugihara, K. (2009). How India clothed the world: The world of South Asian textiles, 1500-1850. Leiden: Brill.

Roy, T. (2006). Roots of Agrarian Crisis in Interwar India: Retrieving a Narrative. Economic and Political Weekly, December 30, pp. 5389-5400.

Roy, T. (2007). A delayed revolution: Environment and Agrarian change in India. Oxford Review of Economic Policy, 23(2), 239-250.

Sato, H. (1996). Taiwan no Keizai Hatten ni okeru Seifu to Minkan Kigyo: Sangyo no Sentaku to Seika [Government and private enterprises in the economic development of Taiwan: Choice of industries and their performance]. In T. Hattori \& Y. Sato (Eds.), Kankoku, Taiwan no Hatten Mekanizumu [Patterns of development of South Korea and Taiwan] (pp. 87-118). Tokyo: Ajia Keizai Kenkyusho.

Sawai, M. (2012). Kindai Nihon no Kenkyu Kanhatsu Taisei [Modern Japan's system of technological research and development]. Nagoya: Nagoya Daigaku Shuppankai.

Scott, J. C. (2009). The art of not being governed: An Anarchist history of Upland Southeast Asia. New Haven: Yale University Press.

Seki, H. Nihon no Kogyo Seisan no Sakan na Chiiki [Main districts of industrial production in Japan]. http://hiroseki.sakura.ne.jp/industry.html, Accessed 9 August 2018. 
Shar, T. (2009). Taming the Anarchy: Groundwater governance in South Asia. Washington DC: Resource for the Future Press.

Singh, A. (1979). The "basic needs" approach to development vs the new international economic order: The significance of third world industrialization. World Development, 7(6), 585-606.

Sugihara, K. (1994). The development of an informational infrastructure in Meiji Japan. In L. Bud-Frierman (Ed.), Information Acumen: The understanding and use of knowledge in modern business (pp. 75-97). London: Routledge.

Sugihara, K. (1996). Ajiakan Boeki no Keisei to Kozo [Patterns and development of intra-Asian Trade]. Kyoto: Mineruva Shobo.

Sugihara, K. (Ed.). (2005). Japan, China and the growth of the Asian international economy, 1850-1949. Oxford: Oxford University Press.

Sugihara, K. (2012). "Kaseki-shigen Sekai Keizai" no Koryu to Baiomasu Shakai no Saihen [The emergence of a 'Fossil-fuel-driven world economy' and the reorganization of the biomass society]. In K. Sugihara, K. Wakimura, K. Fujita, \& A. Tanabe (Eds.), Rekishi no nakano Nettai Seizonken: Ontai Paradaimu o Koete [The tropical humanosphere in global history: beyond the temperate zone paradigm] (pp. 164-179). Kyoto: Kyoto Daigaku Shuppankai.

Sugihara, K. (2013a). 'Sengo Aji ni okeru Kogyoka-gata Kokusai Chitsujo no Keisei [The emergence of an industrialization-driven international order in post-war Asia]. In S. Akita (Ed.), Ajia kara Mita Gurobaru Hisutori: 'Choki no 18-seiki' kara 'Higashi-ajia no Keizaiteki Saiko' e (pp. 283-307). Kyoto: Mineruva Shobo.

Sugihara, K. (2013b). Labour-intensive Industrialization in global history: An interpretation of East Asian experiences. In G. Austin \& K. Sugihara (Eds.), Labour-intensive industrialization in global history (pp. 20-64). London: Routledge.

Sugihara, K. (2015). Asia in the growth of world trade: A Re-interpretation of the "Long Nineteenth Century". In U. Bosma, \& A. Webster (Eds.), Commodities, ports and Asian Maritime Trade $c$. 1750-1950 (pp. 17-58). Basingstoke: Palgrave Macmillan.

Sugihara, K. (2017). Monsoon Asia, intra-regional trade and fossil-fuel-driven industrialization. In G. Austin (Ed.), Economic development and environmental history in the Anthropocene: Perspectives on Asia and Africa (pp. 119-144). London: Bloomsbury Academic.

Sugihara, K., \& Wong, R. B. (2015). Industrious revolutions in early modern world history, In J. H. Bentley, \& S. Subrahmanyam (Eds.), Cambridge world history, Vol. 7: The Construction of a Global World, (2), 283-309. Cambridge: Cambridge University Press.

Takanaka, K. (2000). Higashi-ajia Choki Keizai Tokei 9: Gaikoku Boeki to Keizai Hatten [Longterm economic statistics of East Asia, Vol. 9, foreign trade and economic development]. Tokyo: Keiso Shobo.

United Nations Development Programme (UNDP). (1996). Human development report 1996. New York: UNDP.

van Liemt, G. (1992). Introduction. In van Liemt (Ed.), Industry on the move: Causes and consequences of international relocation in the manufacturing industry. Geneva: ILO.

Wade, R. (1990). Governing the market: Economic theory and the role of government in East Asian industrialization. Princeton: Princeton University Press.

Will, P.-E., \& Wong, R. B. (1991). Nourish the people: The state civilian granary system in China, 1650-1850. Ann Arbor: University of Michigan.

Wong, R. B. (1997). China transformed: Historical change and the limits of European experience. Ithaca NY: Cornell University Press.

International Monetary Fund (IMF). (various years). Direction of trade statistics yearbook.

Yanagisawa, H. (Ed.). (2015). Community, commons and natural resource management in Asia. Singapore: NUS Press.

Zhou, M. (2007). Chugoku Keizairon: Kodo Seicho no Mekanizumu to Kadai [Essays on the Chinese economy: The mechanism of high-speed growth and its problems]. Tokyo: Nihon Keizai Hyoronsha. 
Open Access This chapter is licensed under the terms of the Creative Commons AttributionNonCommercial-NoDerivatives 4.0 International License (http://creativecommons.org/licenses/bync-nd/4.0/), which permits any noncommercial use, sharing, distribution and reproduction in any medium or format, as long as you give appropriate credit to the original author(s) and the source, provide a link to the Creative Commons license and indicate if you modified the licensed material. You do not have permission under this license to share adapted material derived from this chapter or parts of it.

The images or other third party material in this chapter are included in the chapter's Creative Commons license, unless indicated otherwise in a credit line to the material. If material is not included in the chapter's Creative Commons license and your intended use is not permitted by statutory regulation or exceeds the permitted use, you will need to obtain permission directly from the copyright holder.

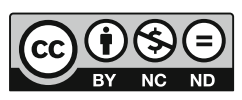




\title{
Chapter 4 \\ Financing Colonial State Building: \\ A Comparative Study of the 19th \\ Century Singapore and Hong Kong
}

\author{
Takeshi Onimaru
}

\begin{abstract}
Modern state building in Asia dates back to the mid 19th century. By that time, most parts of East and Southeast Asia other than Japan, China, and Siam had been colonized by the Western powers. In these colonized countries, modern states were built from the above by colonizers. This chapter reveals the process of such modern state building under the colonial rule by comparing colonial policies on revenue raising and policing in Singapore and Hong Kong.
\end{abstract}

\subsection{Introduction}

In Asia, modern state building began in the mid-19th century. By that time, most parts of Asia other than Japan, China, and Siam had been colonized by the Western nations. The paths of economic and political changes in the next century and a half depended critically on how soon a modern state was built and what kind of institutions it had. Thus, the several decades of modern state building since the mid 19th century was a critical juncture in the sense of Acemoglu and Robinson (2012), who argue that the inclusiveness of political and economic institutions has long-lasting impacts.

It is not true that only independent countries, as opposed to colonies, could have modern state building. In the colonized parts of Asia, modern states were built from the above, as Shiraishi (2000: 58-60) argues. The colonial states, however, were not full-fledged modern states. Since the transformation into a modern state under colonial rule was limited, the leaders of independence after World War II had to build or strengthen some core institutions by themselves. Still, they inherited structures, institutions, and personnel from the colonial states. The difficulty that these leaders had to face would depend much on the legacy of the previous modern state building under colonial rule.

Asian states and economies have emerged one after another since World War II. The resurgence of Japan as an economic power was followed by the rise of the four Asian Tigers (Singapore, Hong Kong, Taiwan, and South Korea) and Southeast Asia,

\footnotetext{
T. Onimaru (凶)

Kyushu University, Fukuoka, Japan

e-mail: onimaru@scs.kyushu-u.ac.jp
}

(C) The Author(s) 2019

T. Shiraishi and T. Sonobe (eds.), Emerging States and Economies, Emerging-Economy

State and International Policy Studies, https://doi.org/10.1007/978-981-13-2634-9_4 
and the even more impactful rise of People's Republic of China as a political and economic power. Asia is a hot spot of emerging-economy states. The understanding of modern state building under colonial rule as the origin of the current states seems crucial to better understanding of the emergence of Asia.

This chapter takes a first step toward the understanding of the processes of modern state building in colonies in the 19th century Asia. It focuses on cities, which have historically played leading roles in economic and political developments of states, just as Braudel (1992) illustrates by using the rise and fall of Venice, Genoa, Antwerp, Amsterdam, and London as examples. This chapter, as a first step, simplifies analysis by focusing on British colonial city states, Singapore and Hong Kong.

The two city states shared several commonalities. At the time of colonization (that is, 1819 in Singapore and 1842 in Hong Kong), both were expected to serve as regional centers of the British Free Trade Empire in East and Southeast Asia. Thus, they became free ports, where no custom duties were charged. Being free ports boosted trade, thereby enabling the two states to come up with expectation, and invited a large inflow of migrant workers predominantly from China. In the case of Singapore, migrant workers came also from India and other parts of Asia. Population increased rapidly in Singapore and even more rapidly in Hong Kong from the mid-19th century to the turn of the century.

In the mid-19th century East and Southeast Asia, states in these regions expanded administrative control over their territories, but much of their power and wealth rested on capital cities and port cities, such as Rangoon, Penang, Batavia, Singapore, Bangkok, Saigon, Hanoi, Manila, Hong Kong, Shanghai, Kobe, Yokohama and Tokyo. Bringing prosperity to these cities was a major task of the states. The question arises as to what consequences for state building such endeavors had.

As trade expanded and the population increased, public administration assumed increasing importance in these colonies. As one would expect, institutions for policing and financing were particularly important from the early period. Because the colonial governments refrained from levying taxes on trading for the purpose of promoting trade, they had to find a source of revenue elsewhere. The two otherwise similar city states differed critically in this respect: Hong Kong did not have any particularly large source of revenue whereas opium farming in Singapore accounted for almost half of the government revenue. If trade could have been the major source of revenue in both states, such a socio-economic difference would not have had significant implications. Because of the vital importance of raising revenue from somewhere else than trade, however, this difference led to significant differences in the formation and nature of financing and policing institutions between the two colonial states. The purpose of this chapter is to present historical supports to this hypothesis. ${ }^{1}$

The rest of this chapter is organized as follows. While Sect. 4.2 describes the revenue raising and policing practices in the 19th century Singapore, Sect. 4.3 describes the counterparts of Hong Kong. Section 4.4 compares the policies in the two states

\footnotetext{
${ }^{1}$ Although we do not deny the possibility that the same difference led to the divergence between the two states' fates after World War II, exploring such a possibility is beyond the scope of this chapter.
} 
Table 4.1 Population and government revenues in the 19th century Singapore

\begin{tabular}{l|l|l|l|l|l}
\hline Year & Population & \% Chinese & Year & $\begin{array}{l}\text { Revenue } \\
(\text { Spanish \$) }\end{array}$ & \% Opium \\
\hline 1824 & 10,683 & 31.0 & $1820-21$ & 15,925 & 46.1 \\
\hline 1834 & 26,329 & 40.8 & $1830-31$ & 96,331 & 40.7 \\
\hline- & - & - & $1840-41$ & 142,900 & 45.5 \\
\hline 1849 & 52,891 & 52.9 & $1849-50$ & 172,375 & 50.8 \\
\hline 1860 & 81,734 & 61.2 & $1860-61$ & 492,853 & 54.1 \\
\hline 1871 & 97,111 & 56.1 & 1870 & 875,690 & 41.1 \\
\hline 1881 & 139,208 & 62.3 & 1880 & $1,277,413$ & 47.0 \\
\hline 1891 & 141,300 & 71.0 & - & - & - \\
\hline
\end{tabular}

Sources The population data are taken from Makepeace et al. (1991: 355-359). The revenue data are taken from HKARR Vol. 1 (Jarman 1996 Vol.1: 71-73, 96-97)

and explains how the socio-economic structures had significant implications for their policies and fates. Section 4.5 offers concluding remarks.

\subsection{Singapore}

\subsubsection{Population}

Singapore was established as a British colony by Sir Stanford Raffles in 1819. It was just a small village then, but it soon became a center of intra-Southeast Asian trade (Kobayashi 2013). Its population grew throughout 19th century in Singapore, as shown in Table 4.1. The table also shows the percentage share of Chinese migrants in the population. While migrants came from various regions including India and other parts of South and Southeast Asia, the main driver of the population growth was Chinese immigrants, especially those from Southern China. The immigrants contributed to the expansion of trade, economy, and government revenues, but they were also serious threats for maintaining public order as we will see shortly.

\subsubsection{Revenue ${ }^{2}$}

As mentioned above, the colonial government in Singapore could not obtain any revenue from trade, potentially the large source of its revenue, because of its free trade policy. Its revenue, however, grew steadily throughout the 19th century, as shown in Table 4.1. What made the revenue growth possible?

\footnotetext{
${ }^{2}$ This section, especially the description of opium farming, is based on Trocki (1990).
} 
From the annual reports in 1868, the sources of revenue in Straits Settlements (Singapore, Penang and Malacca) were (1) excise duties on opium, spirits, toddy (or liquor made from palm), and bhang (or drug made from cannabis for smoking), (2) small duties on tin mining, timber cutting, brick making, granite cutting, and so on, (3) licenses for keeping spirit-shops, public-house, and pawnbrokers' establishments, (4) letting the public markets, (5) stamp duties, and (6) revenue from land. Except these duties, there were municipal taxes on houses, lands, and horses and carriages. These municipal taxes were used for keeping order in the towns and the maintenance of the police forces (Jarman 1998 Vol. 2, p. 32).

The most profitable source of revenue in Singapore throughout 19th century was the opium farm (see Table 4.3). For example, during 1820 to 1882, the opium farm accounted, on average, for $44.3 \%$ of total revenue, and the highest peak was $55.6 \%$ in 1841-1842 and the lowest was 31.8\% in 1826-27 (Trocki 1990, pp. 71-73, 96-97).

The opium farm was one to three years contract, and the right to run the farm was basically put to auction. The person who bid the highest price became a farmer. The farmer bought raw opium from the government and processed raw opium into prepared opium. The farmer retailed prepared opium directly to consumers, but at the same time he sold it to opium dens and plantations as a wholesaler. He paid rents from his sales to the government, and the residuals were farmer's income. The government prohibited the smuggling and sale of opium outside opium farming scheme by law not only to protect the farmer but also to secure revenue from opium (Trocki 1990: 73-76; Yen 1986: 227, 1995: 151-152).

The main consumers of opium were Chinese laborers who worked at plantations cultivating pepper and gambier, whose extract could be used for leather tanning, in the inland Singapore. For those who only know contemporary Singapore, it would be hard to imagine that the city of Singapore was limited to around the Singapore river mouth and the inland Singapore was covered with tropical jungle. Until the 1870s, accessing the inland was difficult especially for Europeans, and if the government tried to collect taxes from the inland populations, opium farm was the best way to do that (Song 1967: 34; Trocki 1990: 48, 70; Wong 1991: 52-53).

At the initial stage, opium farm was run by Hokkien Chinese born in Malacca Straits. Europeans regarded them as "respectable Chinese" because most of them were merchants and city dwellers, could understand some English, and had strong economic ties with Europeans. On the other hand, inland plantations were mainly managed by Teochew Chinese. And if Hokkien opium farmers wanted to sell opium to laborers who worked at inland plantations, it was necessary for them to cooperate with Teochew planters. This cooperation came about through the establishment of a syndicate between Hokkien merchants and Teochew planters. Collaboration between Hokkien and Teochew was also favorable for the colonial government because it was useful to secure opium revenue. The syndicate was organized through revenue farming scheme. From the mid-1840s, two important and lucrative revenue farm, opium and spirits, were owned by this syndicate. Members of the syndicate were changed in ten to fifteen years but this syndicate occupied opium and spirits farms till the 1880s (Trocki 1990: 5, 97-107, 117-148). 
Singapore's revenue heavily relied on opium farm, and the alliance among the colonial government, Hokkien merchants, and Teochew planters through revenue farm was necessary to secure opium revenue. Main consumers of opium were Chinese populations in Singapore, so it could be said that the colonial government created the scheme to finance state building by absorbing Chinese money through this alliance.

\subsubsection{Policing "Secret Societies"}

\subsubsection{Chinese Society and "Secret Societies"}

It was in 1890 when secret societies were prohibited by law in Singapore. From the establishment of Singapore in 1819, they were in fact "lawful" organizations during almost 70 years. And they played important roles in the Chinese society in Singapore, politically, economically, and socially.

The history of secret societies in Singapore was almost the same as the history of colonial Singapore. It was said that secret societies were already existed in 1824 . In the early 1840s, Hokkien, Teochew, Canton, and Hakka Chinese organized their own secret societies respectively, and total members were about six thousands (Gillis 2005: 24; Lee 1991: 25). William A. Pickering, who served as the first Protector of Chinese in Singapore in 1877, wrote in 1876 that "60\% of the Chinese in our colonies and the native states are sworn members of secret societies: of the remaining $40 \%$, most are subject to their influences (Pickering 2000: 311)."

Thus secret societies had strong influence in Singapore and this influence was based on two functions they played in Chinese societies. The first function was providing a kind of social safety or mutual aid for immigrants. Most immigrants were young and poor newcomers, called “sinkheh (新客)," and contracted immigrants. When the colonial government did not provide immigrants with enough legal protections, they needed institutions to find a job, to secure personal security and protection in case of being sick or unemployment. And organizations called kongsi (公司) or hoey (会) provided these services for newcomers. This kongsi or hoey was organized respectively by five topolect groups (Hokkien, Teochew, Canton, Hakka, and Hainan) in Chinese societies because Chinese societies in Singapore were divided into these five topolect groups and it was difficult to understand each other among different topolect groups (Lee 1991: 27-28; Shiraishi 1975: 82, 2000: 62).

The second function was related to Chinese economic activities in Singapore. As Chinese societies in Singapore were divided into five topolect groups, Chinese economic activities were also divided along with topolect groups. For example, Hokkien was mainly engaged in commerce, and Teochew managed inland plantations. And, to protect economic interests and dominance in their "niche" occupations, Chinese elites in Singapore, who were traders, merchants, and plantation owners and called “Taukeh (頭家)", utilized and relied on kongsi or hoey, so called "secret societies". These kongsi and hoey were in charge of the labor recruitment and control and the 
actual management of plantations and mining (Lee 1991: 27-28; Mak 1981: 41-43, 45, 49; Shiraishi 1975: 78-80; Yen 1986: 122).

Secret Societies not only sought to protect their members' economic interests or "turf" against rival groups; in case of disputes among members who belonged to different organizations, konsi or hoey frequently resorted to violence, killing each other and caused riots (Blythe 1969: 2). These frequent violent disputes and riots were serious threats for the colonial order, and it was quite natural that government officials and Europeans branded kongsi and hoey as "criminal" and "violent" organizations and called them "secret societies". Another reason why kongsi and hoey were regarded as "secret societies" was that there was no government official who could understand Chinese languages until the 1870s and all negotiations, rituals and activities by kongsi and hoey were deemed to be "conspiratorial" in the eyes of government officials.

\subsubsection{2 "Secret Societies" as a "Necessary Evil"}

Although violent disputes and riots caused insecurity in Singapore, secret societies were not banned legally till 1890 . The biggest reason why secret societies were not made illegal until a long after was that secret societies played an important role in the opium farm.

As mentioned above, the opium farm was the most lucrative source of revenue for the colonial government in Singapore. And those who consumed opium most were Chinese laborers employed in inland plantations. Secret societies managed these plantations, controlled laborers, and sold opium to them. Opium farmers also utilized secret societies for protecting and promoting their sales and for suppressing smuggling (Trocki 1990: 77; Wong 1991: 54; Yen 1986: 115, 122).

If the colonial government wanted to secure opium revenue, and when it could not directly collect opium revenue and other taxes from inland, the existence of secret societies was tolerated as a necessary evil. Controlling crimes, violent disputes and riots caused by secret societies was the task of the colonial police force, but unfortunately the police force did not have enough power to police the activities of secret societies.

Like the government, there was no police officer who could understand Chinese languages. And Chinese were not hired for the police force because the government was afraid of influence and penetration of secret societies into the police force. And this concern was true, because, even though there was no Chinese police official, secret societies could succeed in penetrating into the police. In 1860 s, several police officers were fired because of their membership of secret societies (Jarman 1998 Vol. 1: 464; Lee 1991: 35).

Criminals were harbored by secret societies, and in case of their arrests, witnesses did not testify properly because they were afraid of revenge. Most of Chinese translators hired for interrogation were members of secret societies (Blythe 1969: 2-3). 
Thus, as long as secret societies were tolerated as a necessary evil, it was impossible for the police to control the activities of secret societies. But this situation changed from the late $1860 \mathrm{~s}$, when the government started to shift its policy from tolerance to suppression.

\subsubsection{From Necessary Evil to Suppression}

Suppression against secret societies by the colonial government began in 1867 . The backgrounds of this policy shift were (1) the reduction of inland plantations and (2) the changing nature of secret societies.

Pepper and gambier plantations in inland Singapore were abolished and planters moved to Johore till the late 1860 s because of the degradation of the soil and the decrease of uncultivated lands. Moreover, from the 1860s onward, road access to inland Singapore was improved and the inland itself began to undergo urbanization. These changes enabled the colonial government to collect taxes from inland directly, and more importantly, created the condition that the government did not necessarily rely on secret societies to secure opium revenue (Jarman 1998 Vol. 1: 36; Vol. 2: 106; Trocki 1990: 149; Wong 1991: 53).

At the same time, the nature of secret societies had been changing. From around 1870, professional fighters called “samseng (三星)" came to Singapore from mainland China because of the end of Taiping Rebellion there. They joined secret societies in Singapore, and, by their participation, transformed secret societies into much more violent organization, triggering incessant violent riots in Singapore in the early 1870s ${ }^{3}$ (Lee 1991: 34-35, 42; Trocki 1990: 159-160).

These two factors - the decreasing importance of secret societies to secure opium revenue and the transformation of secret societies into mere violent and criminal organizations-gave impetus to the colonial government to shift its policy from tolerance to suppression.

The actual processes of suppression began in 1867. In this year, the governor got the power to deport those who caused insecurity in the colony by the ordinance. At this stage, deportation was only possible under the declaration of emergency, but it was effective measure for criminals and rascals because they were afraid of being detained in mainland China and executed there after deportation (Lee 1991: 57; Turnbull 1989: 88).

The next step was taken in 1869 when societies, including secret societies, were forced to register themselves by the ordinance. Registration was only required of societies or associations composed of more than ten members. By this ordinance, the government could obtain information about secret societies, order these societies to report before their meetings, make police officers attend the meeting, and oblige

\footnotetext{
${ }^{3}$ From 1871 to 1873 , four violent riots occurred in Singapore: (1) riots among secret societies on March 1871; (2) riots between Hokkien and Teochew workers on October 1871; (3) riots against the government regulation on October 1872; and (4) riots between Hokkien and Teochew secret societies from December 1872 till February 1873 (Jarman 1998 Vol. 2: 137; Blythe 1969: 155-156; Lee 1991: 35-41; Yen 1986: 197).
} 
secret societies to compensate losses caused by their riots. The first registration was carried out in 1869, and the ordinance, originally effective one year only, was extended several times, and finally was made permanent (Jarman 1998 Vol. 2: 141; Blythe 1969: 151-152; Lee 1991: 59-60).

The government started to police secret societies by way of deportation and registration, and then tried to intervene in Chinese labor control and protection by depriving secret societies of their socio-economic roles in Chinese society. In other words, the state took over the "state-like" functions of the secrets societies. To achieve this purpose, the Chinese Protectorate was established in 1877 and William A. Pickering, who was appointed to the first Protector of Chinese, was a suitable person for this mission (Blythe 1969: 167-168; Turnbull 1989: 85).

Pickering was the first government officer who was good at Chinese languages. He started to control and protect Chinese immigrants through making or checking their labor contracts by himself. Pickering was also in charge of registration of societies. From 1877, he began to re-register societies and associations together with Samuel Dunlop, Inspector General of Police, and this re-registration was successfully finished in 1878 (Blythe 1969: 205, 207; Lee 1991: 71; Turnbull 1989: 85).

In the 1880 s, the colonial government took further steps to regulate secret societies. Societies and associations to which a British citizen belonged were banned and the government could illegalize any societies regarded as dangerous for public order in 1882. And from 1885, the government could anytime deport undesirable persons. Along with these legal procedures, the government officials who could understand Chinese languages were increased. From the 1880s, cadets who would be in charge of Chinese affairs dispatched to Amoy (厦門), Swatow (汕頭), and Canton (広州) to learn Hokkien, Teochew, and Cantonese languages. The police force was also reformed. In 1881, a training school for police officers was opened, and the department specialized in criminal investigation was established in 1884 (Blythe 1969: 213; Lee 1991: 97; Turnbull 1989: 84, 88).

In 1887, Sir Cecil C. Smith, who had been the colonial officer in charge of Chinese affair in Hong Kong, became a Governor of Straits Settlements, and he took the final step to illegalize secret societies (Blythe 1969: 220; Lee 1991: 151).

First attempt to illegalize secret societies was in 1888 when Cecil Smith drafted the bill for complete illegalization. But this attempt was opposed by both Pickering and Dunlop, because they thought that it was better to suppress secret societies gradually. Regardless of their opposition, Smith submitted the bill to the Legislative Council of the Straits Settlements, but it was rejected. He resubmitted the modified bill in 1888 and this time, it was passed in 1889. The ordinance was in force in 1890, and the illegalization of secret societies was achieved in Singapore (Lee 1991: 134-144).

Even though secret societies were legally prohibited, they were not gone completely. But their influence in Chinese societies in Singapore declined and the colonial government was no more bothered with violent riots caused by secret societies (Blythe 1969: 225-234; Lee 1991: 135-151; Turnbull 1989: 87-89). 
Table 4.2 Population and government revenues in the 19th century Hong Kong

\begin{tabular}{l|l|l|l|l}
\hline Year & Population & \% Chinese & Year & Revenue (£) \\
\hline 1844 & 19,463 & 97.6 & 1845 & 22,242 \\
\hline 1850 & 33,143 & 96.4 & 1850 & 23,526 \\
\hline 1860 & 94,917 & 97.3 & 1860 & 94,182 \\
\hline 1870 & 119,477 & 96.5 & 1870 & 190,673 \\
\hline 1881 & 160,402 & 93.9 & 1880 & 222,905 \\
\hline 1891 & 221,441 & 95.2 & - & - \\
\hline
\end{tabular}

Sources Both population data and the revenue data are taken from HKARR Vol. 1 (Jarman 1996 Vol. 1)

\subsection{Hong Kong}

\subsubsection{Population}

Hong Kong was ceded by Treaty of Nanking in 1842 . Hong Kong in 1842 was a barren rocky island (Gillis 2005; Welsh 1997). It became an entrepôt between east and west (Hamashita 1996; Hisasue 2012). As shown in Table 4.2, the population of Hong Kong was dominated by Chinese, who came mainly from Canton province

\subsubsection{Revenue}

As with Singapore, the Free Port policy was applied to Hong Kong and the colonial government in Hong Kong could not impose custom duties. Once the government tried to introduce a poll tax but it was failed (Jarman 1996 Vol. 1: 612; Welsh 1997: 170-171). Even though the government could not get any revenue from the most lucrative economic activities in the colony, the total revenue in Hong Kong had been increased steadily throughout 19 th century (see Table 4.2).

The main sources of revenue in Hong Kong in 19th century were (1) land revenue, (2) rents on markets and buildings, (3) licenses on spirits retailers, pawnbrokers, opium monopoly, emigration brokers, money changers, and so on, (4) taxes on stamps, police, water, lighting, and fire brigade, and (5) fines and fees (Jarman 1996 Vol. 1; Welsh 1997: 265). Table 4.3 shows the composition of government revenue in 1848 and 1869 , even though comparison is not straightforward as the revenue classification varied over time.

The primary source of revenue had been shifted from time to time. In 1848, it was rents $^{4}$ from lands $(53.5 \%)$, but it was replaced by taxes $(29.7 \%)$ in 1869 . It is clear that

\footnotetext{
${ }^{4}$ Rents in 1848 were collected from lands, markets, and houses (Jarman 1996 Vol. 1: 89).
} 
Table 4.3 Government revenue by source in 1848 and 1869

\begin{tabular}{|c|c|c|c|c|}
\hline \multirow[t]{2}{*}{ Sources } & \multicolumn{2}{|l|}{1848} & \multicolumn{2}{|l|}{1869} \\
\hline & Amount (£) & $\%$ & Amount (\$) & $\%$ \\
\hline Rents & 16,630 & 53.5 & 50038.47 & 5.4 \\
\hline Land revenue & - & - & 132811.68 & 14.4 \\
\hline Licenses & 6786 & 21.8 & 159847.60 & 17.3 \\
\hline Police rates & 2240 & 7.2 & - & - \\
\hline Taxes & - & - & 274529.60 & 29.7 \\
\hline Postage & - & - & 64854.28 & 7.0 \\
\hline Fees and fines & 4170 & 13.4 & 5963822 & 6.5 \\
\hline Mint & - & - & 60192.71 & 6.5 \\
\hline Miscellaneous & 1252 & 4.1 & 112872.37 & 12.2 \\
\hline Total & 31,078 & 100 & 923653.01 & 100 \\
\hline
\end{tabular}

Source HKARR Vol. 1 (Jarman 1996 Vol. 1)

sources of revenue in 1869 were more diversified than that of 1848 . The divergence would reflect the commercial as well as urban development in Hong Kong.

For the purpose of this chapter, the most important point that Table 4.3 makes is that unlike Singapore, opium was never the most lucrative source of revenue in the 19th century Hong Kong. In the annual administrative report for 1877, Sir John Pope Hennessy, the Governor of Hong Kong, complained as follows (Jarman 1996 Vol. 1: 596):

Now, what has happened about the Opium farm? It fetched in $1875, \$ 137,000$ for the whole year; in 1876, $\$ 133,000$; and this year we will receive from it only $\$ 132,000$. The Opium farm is declining in value, because it has been sold to the Opium farmer at a slight falling-off in value. Well, it is a curious fact that, while the Opium farm has been declining in value, the number of chests of Opium forwarded to this Colony have been increasing year by year. It is very remarkable that our trade in Opium with California, Australia, and a few other places, has been increasing, that our Chinese population has not been declining, and that nevertheless our Opium farm has been declining. What has happened in the Straits Settlements? The farms there sold in 1876 for $\$ 837,000$. They have been re-let now for $\$ 1,020,000$, the increase in all the Penang farms being $\$ 161,000$, and in the Singapore Opium farm $\$ 28,000$. Whilst they have been increasing, we have been falling back. In Hong Kong, there are 130,000 Chinese; in the Straits Settlements, 104,000.

The share of opium farm for total revenue was not as high as Singapore. For example, that was $9.9 \%$ in fiscal year $1845-1846,11.8 \%$ in 1869 , and $16.7 \%$ in 1876 (Jarman 1996 Vol. 1: 29, 347, 470).

Opium farming was introduced in Hong Kong in 1844. At the initial stage, the government farmed out the right of distribution of opium in Hong Kong less than $160 \mathrm{lb}$ to single farmer. This scheme of monopoly was changed to selling the licenses to retailers or retail shops, but the amount from opium licenses declined in 1848 and 1849 (Jarman 1996 Vol. 1: 93, 119; Cheung 1986: 4-6, 25).

In 1858, opium license scheme was abolished and opium farm was introduced in order to increase the amount of tax from opium. Under this opium farm, a single 
farmer could get the right to sell and export fixed amounts of processed opium (Eitel 1895: 336; Welsh 1997: 348; Cheung 1986: 13-14, 29).

Opium farm had been in practice till 1883. In this year, the government got the information that opium farm was dominated by the syndicate between two opium traders and the bid price of opium farm was made deliberately lower than expect. To destroy this syndicate, the government reintroduced license scheme in 1883, but two years later, in 1895, opium farm was re-established again (Cheung 1986: 6).

The colonial government in Hong Kong went back and force, or made trial and error, to maximize opium revenue, but the share of opium in total revenue had not been increased as expected. One reason why opium revenue had not been lucrative in Hong Kong was that opium farm was monopolized by the above mentioned syndicate. In addition to this, it was also mattered that the government could not control or suppress the opium smuggling from Macau or mainland China (Cheung 1986: 31-33, 42, 60-61).

In the administrative report for 1881, the Governor Hennessy mentioned that over $90 \%$ of total revenue came from Chinese (Jarman 1996 Vol. 1: 612). All five sources, land revenue, rents, licenses, taxes, and fines and fees, were born by Chinese because Chinese were dominant in population (over 90\%) and economic activities from small retailers to big traders in Hong Kong. Even though opium farm had not worked well, the colonial government in Hong Kong could succeed in creating the system to collect revenue from Chinese population or their activities there.

\subsubsection{Policing Colonial Hong Kong}

Secret Societies such as Triad Society (三合会) were illegalized in Hong Kong in 1845, just three years after the cession and almost a half century earlier than Singapore. By the illegalization, the members of secret societies were imprisoned for three years, or deported from Hong Kong, or tattooed inside arm (Criswell and Watson 1982: 15-16). Although secret societies were legally banned, they continued to exist in Hong Kong, ${ }^{5}$ and, in 1887, the colonial government renewed the ordinance by which the government could punish not only leaders and members of secret societies but also supporters for them (Ball 1924 Vol. 1: 5, 52; Lee 1991: 140).

Why did the colonial government illegalize secret societies in Hong Kong in the very early stage of colonial state building? Undoubtedly, domestic security, especially protecting British and European peoples in the colony, was the most important factor to suppress secret societies. At the same time, another factor was also mattered: that was, to prevent that secret societies were utilized for anti-British movements.

\footnotetext{
${ }^{5}$ Most members of secret societies were lower class Chinese in Hong Kong. Basically, upper class Chinese did not take part in secret societies because Hong Kong was politically stable and the domestic order was relatively maintained, so they did not need to rely on secret societies for their securities (Tsai 1993: 112-113).
} 
In 19th century Hong Kong, the most serious threats for maintaining order except ordinary crimes were strikes and riots caused by Chinese workers. These strikes and riots could be classified into two types according to their motives and causes. The first one was strikes against the regulations of the government, and for this type of social disorder, in most cases, the government could reject striker's appeals and forced to end strikes relatively soon, except anti-poll tax strike in 1844. This was because Chinese workers could not continue strikes from their hardships and the government could easily get alternative labor forces from Amoy or Swatow (Tsai 1993: 11, 180).

On the other hand, the second type, riots and disputes fueled by anti-British sentiments, was not easily dampened. From the very beginning of the colony of Hong Kong, anti-British sentiments were in high tide not only in the colony but also in the surrounding region.

For example, after the Opium War, the relationship between Britain and ChingChina in Canton was very bad, and the relationship between the British and the Chinese population in Hong Kong was also perilous. On September 1849, there was a rumor that those who assassinated Sir George Bonham, the governor of Hong Kong at that time, would be rewarded by the Ching government, and Bonham needed to be guarded by the army when he went out in the colony (Tsai 1993: 41).

During the Arrow War (1856-1860), the anti-British sentiments were rising again. In 1857 , the incident that breads were poisoned by arsenic was occurred, and next year, more than two millions Chinese left Hong Kong to their homes because they did not want to work under Europeans (Tsai 1993: 51-55).

The most serious dispute in 19th century Hong Kong was the strikes and riots caused by Sino-French War (1884-1885). The dispute was triggered by the fact that a French Frigate stopped at Hong Kong in 1884. To protest this, Chinese dock workers refused to repair ships, and then strikes and riots by Chinese mobs fueled by anti-British sentiments were continued from 18th September till 6th October 1884. The economic activities in Hong Kong were almost suspended by this dispute until the colonial order was restored by the police and the army and also workers went back to their jobs because of their hardships (Tsai 1993: 126-129).

And if secret societies were involved in these anti-British movements and mobilized Chinese population for these movements and disputes, it would be really a nightmare for the colonial government. And that was why the illegalization of secret societies was implemented in 1845 , the very early stage of the colonial rule in Hong Kong. Apart from the legal prohibition of secret societies, what measures were taken to keep public order in Hong Kong?

The first measure was registration. In Singapore the target of registration was secret societies, but in Hong Kong the government tried to register Chinese population itself. The first attempt of registration was taken in 1844. The Legislative Council in Hong Kong enacted the ordinance to control Chinese population, to monitor the inflow of criminals, and to collect one dollar annual poll tax from them by registration. But Chinese residents went on strike against this ordinance, so the Legislative Council modified the ordinance to suspend poll tax, limit the registration to lower class 
Chinese, but to be enabled to take a census regularly (Ball 1924: 4-5; Tsai 1993: 40-41).

This first attempt was ended halfway, and the second attempt by the Governor, Sir John Bowring, in 1857 was also failed (Ball 1924: 15-16; Jarman 1996 Vol. 1: 238,242 ). But in 1866 , the colonial government succeeded in registering all Chinese residents in the City of Victoria, ${ }^{6}$ the "capital" of Hong Kong. The actual registration was conducted mainly by the Registrar-General, Cecil C. Smith who illegalized secret societies in Singapore as the Governor of Straits Settlements later. The data was taken from household survey by summoning owners of each house. In the same year, the colonial government started to register and license Chinese vessels to enter and leave the harbors in Hong Kong (Ball 1924: 25; Jarman 1996 Vol. 1: 305-306).

The second measure was regulating Chinese activities at night time. In 1842, all Chinese ships were prohibited to sail around the harbors after 9 p.m., and also all the Chinese were prohibited to go out after 11 p.m. In next year, they were requested to carry a lantern when they went out after 8 p.m., and not to go out after 10 p.m. In the same year, they were forced to possess a permit to go out after 8 o'clock in the night (Criswell and Watson 1982: 14; Jarman 1996 Vol. 1: 238; Sinn 1989: 10-11; Tsai 1993: 39, 99).

The third measure was to strengthen the police force. In the initial stage, the police in Hong Kong consisted of European and Indian staffs, so it was difficult for them to police crimes by the Chinese because they could not understand Chinese languages. To improve this condition, pao-cha (保甲) system was introduced in 1844. This pao-cha system was to recruit Chinese residents without salary and to make them maintain order with the colonial police force, but this system did not work well for several years (Ball 1924: 4; Sinn 1989: 11-12; Tsai 1993: 39-40).

In 1847, the police force decided to recruit Chinese staffs (Welsh 1997: 164). Immediately, this was regarded as effective measure to strengthen the police force. The superintendent of police reported in 1848 to the Governor, Sir John F. Davis, "the police service has been gradually improving, and the change made in diminishing the English and increasing the native force has proved beneficial (Jarman 1996 Vol. 1: 92)." In 1881, the police force in Hong Kong consisted of 125 Europeans, 314 Chinese, and 171 Sikhs, and more than half were Chinese staffs (Jarman 1996 Vol. 1: 628).

In addition to the formal police force, there was another organization to maintain public order in Hong Kong. That was the District Watch Force. In the early years of Hong Kong, the colonial police force only patrolled the harbor and European districts, and so the Chinese residents organized the District Watch Force by themselves and made it patrol the Chinese districts. In 1866, by the request from the Chinese residents, the government placed this District Watch Force under the command of the Registrar General's Office. The Chinese continued to pay for the cost of the Force and they organized the District Watch Committee to manage the Force under the control of the colonial government (Jarman 1996 Vol. 1: 338; Lee 1991: 65).

\footnotetext{
${ }^{6}$ From Sai Wan (西環) to Wan Chai (灣仔) in Hong Kong island in contemporary Hong Kong.
} 
The final measure was recruiting government officials who could understand Chinese languages. In 1859, there were four government officials who could understand Cantonese in Hong Kong, and one of them, Caldwell, was served as the Registrar General from 1856 to 1861 and reported as a quite efficient official (Jarman 1996 Vol. 1: 236; Welsh 1997: 231). From 1862, the Cadet Scheme was introduced in Hong Kong. This scheme was to select cadets in England by exam, to make them learn Cantonese, and finally to hire them as the government officials in Hong Kong. First cadets came to Hong Kong in 1862, studied Cantonese and later were in charge of Chinese affairs in the government (Endacott 1964: 168; Jarman 1996 Vol. 1: 284, 294, 298).

In Hong Kong, the colonial government illegalized secret societies almost immediately after its cession from the Ching government, and introduced several measures to strengthen policing and surveillance capabilities to maintain the colonial order.

\subsection{Comparison}

There were two major differences in revenue structures and policing practices in Singapore and Hong Kong in 19th century. To begin with, opium farming had been the major source of revenue in Singapore throughout 19th century, but the revenue structure in Hong Kong was much more diverse with opium farming not being as lucrative as that in Singapore. Turning to policing practices, Chinese secret societies in Hong Kong were illegalized at a very early stage, just three years after the cession, while those in Singapore were allowed to exist for almost seventy years from the establishment of colony. Is there any linkage between these differences?

The most important factor was the difference in socio-economic structures between Singapore and Hong Kong. In Singapore, secret societies played quite important roles in both plantation management and revenue collection. Important part of plantation management is to control labor forces consisting of migrants from mainland China. Secret societies took charge of such labor management. Revenues were collected mainly from opium plantation workers. This task was also undertaken by the secret societies since they as personnel in charge of labor management had advantage in this task.

The Chinese society in Singapore was divided along with five dialects groups, Hokkien, Teochew, Canton, Hakka, and Hainan, and secret societies were organized by each dialect group. They were expected to protect economic interest, to provide a kind of social security for newcomers, and to control and monitor labor forces. If the colonial government tried to illegalize secret societies, it would be necessary to establish new institutions that played these roles as substitutes. The multilingual structure of Chinese society made it hard and costly for the colonial government to substitute secret societies.

This is most likely to be the reason why state in Singapore "outsourced" collecting revenue and providing social security and protections for Chinese populaces to secret societies. By doing so, the government saved the cost for institutional building to collect revenue, maintain order, and control Chinese societies. Although riots and 
crimes caused by secret societies made Singapore insecure, the colonial government allowed their existence as a "necessary evil" for several decades.

This arrangement ended finally in the 1877, when the Chinese Protectorate was established as substitutive institution. Afterwards, this institution controlled and monitored Chinese workers without relying on secret societies. Consistent with the above reasoning, this policy change coincided with the major socio-economic change in the 1870s; that is, the economic importance of plantations declined considerably, and accordingly the nature of secret societies was transformed.

In Hong Kong, urban commerce or entrepôt trade was only and the most important economic activity. In order to make this city flourish as trading port, it was essential for the colonial government to maintain order (Endacott 1964: 6). From security point of view, secret societies were regarded as criminal organizations which would disturb domestic order, and that was why they were illegalized as early as in 1845 . The colonial government tried to keep domestic order by introducing registration, regulating Chinese activities at night time, improving police force, and recruiting and training officials who could understand Chinese languages.

In other words, the colonial state in Hong Kong needed to fashion "Leviathan" from the outset. Unlike its counterpart in Singapore, the Chinese society in Hong Kong was predominantly Cantonese and there was no important economic activity except commerce. Moreover, Hong Kong was so close to mainland China that anti-foreigner, especially anti-British, sentiments and events in mainland could have easily spilt over to Hong Kong and created more uncertainty, which was not an issue in Singapore. Under these conditions, it was too dangerous for the colonial government not to illegalize secret societies because they could easily mobilize and unite Chinese populations for anti-British movements. The colonial state should collect revenue, provide security, and control Chinese society by itself, and, for these purposes, it set up state machinery both to collect information and to penetrate into the Chinese society, like registering Chinese populations, issuing permits for their movements, hiring Chinese staffs into the police force, and introducing Cadet Scheme for recruiting and training government officials who could understand Chinese languages and work for Chinese affairs.

\subsection{Concluding Remarks}

How the state raises revenue and maintains order is undoubtedly one of the key questions to understand state formation/building. In the case of the colonial state, raising revenue as much as possible was crucial for financing state building, and in most cases those who bore these taxes were the "natives" who were governed by colonizers. Maintaining order was also almost equal to monitoring and controlling "natives" who were regarded as the source of insecurity and crime. But the actual process and system of raising revenue and maintaining order varied according to the political, economic, and social conditions each colonial state encountered in the course of state building. 
In Singapore, the process of colonial state building in 19th century took the form of minimizing the cost for institutional building on raising revenue and keeping order because the colonial government could rely on secret societies both for collecting revenue from Chinese workers and for providing Chinese society with protection. On the other hand, the colonial state in Hong Kong had to build its own systems to raise revenue from Chinese populace and to monitor and control them not to disturb the colonial order. Even though these two colonial city states shared similarities like British colony, Chinese dominant society, and free trade policy, the state characters in these colonies were different because of their differences in socio-economic structures.

In both cases, Hong Kong from the outset and Singapore from the 1870s when the colonial government switched its policy from indirect and outsourcing measures to more direct and suppressing measures, surveillance was the key instrument to raise revenue and maintain order. Charles Tilly classified the form of taxation into five (tribute, rent, flows, stocks, and income) according to the degrees of monetization and surveillance (Tilly 1992: 87-88). Compared to monetization, he only gave a brief explanation of what kind of role surveillance played in taxation, but it is quite clear that if the state wants to maximize revenue and diversify its sources, more and more information should be collected. Needless to say, surveillance is essential for maintaining order, and that is why many states establish political and criminal intelligence services to collect and analyze information.

But again, what kind of surveillance scheme is introduced in the process of state formation/building and how effective it is will vary according to not only political, economic, and social conditions, but also historical backgrounds each state has. Researching and comparing surveillance schemes or mechanisms in different states, different regions, and different historical periods would be fruitful to understand how state was formed or built and transformed under given political, economic, social, and historical conditions.

\section{References}

Acemoglu, D., \& Robinson, J. A. (2012). Why nations fail: The origins of power, prosperity, and poverty. New York: Crown Publisher.

Ball, A. D. (Ed.). (1924). The ordinances of Hongkong, 1844-1923 (Vol. 1, pp. 1844-1890). Hong Kong: Noronha \& Co.

Blythe, W. (1969). The impact of chinese secret societies in Malaya: A historical study. London: Oxford University Press.

Braudel, F. (1992). The perspective of the world. Berkeley and Los Angeles: University of California Press.

Cheung, T. P. L. (1986). The opium monopoly in Hong Kong, 1844-1887. M Phil. thesis, University of Hong Kong.

Criswell, C., \& Watson, M. (1982). The royal Hong Kong police (1841-1945). Hong Kong: Macmillan.

Eitel, E. J. (1895). Europe in China: The history of Hongkong from the beginning to the year 1882. Hong Kong: Kelly \& Walsh. 
Endacott, G. B. (1964). Government and people in Hong Kong 1864-1962: A constitutional history. Hong Kong: Hong Kong University Press.

Gillis, E. K. (2005). Singapore civil society and British power. Singapore: Talisman Publishing.

Hamashita, T. (1996). Honkon (Hong Kong). Tokyo: Chikuma Syobo.

Hisasue, R. (2012). Honkon: Teikoku no jidai no geitouei (Hong Kong: Gateway in the Era of Empire). Nagoya: Nagoya University Press.

Jarman, R. L. (Ed.). (1996). Hong Kong annual administration reports 1841-1941, (HKAAR) (Vols. 1 and 2, pp. 1841-1886, 1887-1903). Archive Edition.

Jarman, R. L. (Ed.). (1998). Annual reports of the straits settlements, 1855-1941, (ARSS) (Vols. 1, 2, 3 and 4, pp. 1855-1867, 1868-1883, 1884-1891, 1892-1900). Archive Edition.

Kobayashi, A. (2013, December). The role of Singapore in the growth of intra-Southeast Asian trade, c. 1820s-1852. Southeast Asian Studies, 2(3), 443-474.

Lee, E. (1991). The British as rulers: Governing multiracial Singapore 1867-1914. Singapore: Singapore University Press.

Mak, L. F. (1981). The sociology of secret societies: A study of chinese secret societies in Singapore and Peninsular Malaya. Kuala Lumpur: Oxford University Press.

Makepeace, W., et al. (1991). One hundred years of Singapore (Vol. 1). Singapore: Oxford University Press.

Pickering, W. A. (2000). The Chinese in the Straits of Malacca. In Kingsley Bolton and Christopher Hutton (Eds.), Triad societies (Vol. 1). London: Routledge.

Shiraishi, T. (1975). Kamingoeisho no setsuritsu to Kaitou (The establishment of Chinese protectorate and secret societies: Political change in Chinese societies in 19th Century Singapore). Ajia Kenkyu, 22 (2), 75-102.

Shiraishi, T. (2000). Umi no Teikoku (Maritime Empire). Tokyo: Chuo Kouron Sinsya.

Sinn, Elizabeth. (1989). Power and charity: The early history of the Tung Wah Hospital, Hong Kong. Hong Kong: Oxford University Press.

Song, O. S. (1967). One hundred years of the Chinese in Singapore. Singapore: University Malaya Press.

Tilly, C. (1992). Coercion, capital, and European States, AD 990-1992. Cambridge MA: Blackwell.

Trocki, C. (1990). Opium and empire: Chinese society in Colonial Singapore, 1800-1910. Ithaca: Cornell University Press.

Tsai, J.-F. (1993). Hong Kong in Chinese history: Community and social unrest in the British Colony, 1842-1913. New York: Columbia University Press.

Turnbull, C. M. (1989). A history of Singapore 1819-1988 (2nd ed.). Singapore: Oxford University Press.

Welsh, F. (1997). A history of Hong Kong. London: Harper Collins.

Wong, L. K. (1991). Commercial growth before the Second World War. In E. C. T. Chew \& E. Lee (Eds.), A history of Singapore (pp. 41-65). Singapore: Oxford University Press.

Yen, C.-H. (1986). A social history of the Chinese in Singapore and Malaya, 1800-1911. Singapore: Oxford University Press.

Yen, C.-H. (1995). Community and politics: The Chinese in colonial Singapore and Malaysia. Singapore: Times Academic Press. 
Open Access This chapter is licensed under the terms of the Creative Commons AttributionNonCommercial-NoDerivatives 4.0 International License (http://creativecommons.org/licenses/bync-nd/4.0/), which permits any noncommercial use, sharing, distribution and reproduction in any medium or format, as long as you give appropriate credit to the original author(s) and the source, provide a link to the Creative Commons license and indicate if you modified the licensed material. You do not have permission under this license to share adapted material derived from this chapter or parts of it.

The images or other third party material in this chapter are included in the chapter's Creative Commons license, unless indicated otherwise in a credit line to the material. If material is not included in the chapter's Creative Commons license and your intended use is not permitted by statutory regulation or exceeds the permitted use, you will need to obtain permission directly from the copyright holder.

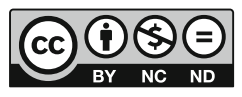




\title{
Chapter 5 \\ China's Emerging State in Historical Perspective
}

\author{
R. Bin Wong
}

\subsection{Clarifying Problems, Formulating an Approach}

China's economic growth since the 1980s has transformed the country from a primarily agricultural society with a socialist planned economy having minimal foreign trade into a major industrial power with a powerful presence on international markets. Rapid growth began with what economist Barry Naughton memorably captured in the phrase "growing out of the plan" and included opening the domestic economy to foreign capital and technology and the growing exports of manufactured goods to Western countries. By the late 1990s Chinese enterprises and entrepreneurs began to increase trade with and investment in African and Latin American governments and firms, promoting resource extraction and infrastructural development in world regions where Western governments and enterprises had long spoken of untapped development opportunities and aspirations. In autumn 2013 President Xi Jinping announced a bold vision of transforming Eurasia into a more integrated economy, reaching populations previously cut off from the transformative possibilities having market access as perennially promised, and linking the Chinese and European economies more closely than ever before.

China's entry into economic globalization during the 1980s put the country in a profoundly different position than that it occupied in the first round of industriallyled economic globalization a century earlier. From an exporter of largely primary products in the 1880s the country became an industrial exporter in the 1980s and 1990s. Globally, with improvements in transportation infrastructure between the mid-nineteenth and early twentieth centuries, railroads and steamships enabled the Western centers of industrialization to forge an international division of labor. Raw materials and agricultural products flowed from less developed societies as industrial products moved in the other direction. By the final decade of the nineteenth century

\footnotetext{
R. B. Wong ( $\varangle)$

University of California, Los Angeles, USA

e-mail: rbwong@international.ucla.edu

(C) The Author(s) 2019

T. Shiraishi and T. Sonobe (eds.), Emerging States and Economies, Emerging-Economy

State and International Policy Studies, https://doi.org/10.1007/978-981-13-2634-9_5
} 
Western capital (principally British) created production not only in industrialized areas but also went to central and eastern Europe, much of which had little to no industry, and to other world regions where entrepreneurs and foreign governments aspired to create wealth and power similar to what they observed in the advanced parts of the West. But most all these efforts had quite modest results for non-Western economies, including China's.

At the same time as states in late nineteenth century Asia and Latin America increasingly aspired to create more effective governments and expand production, American and European states were beginning to understand the complex challenges of capturing the benefits of international trade without exposing major sectors of their domestic economies to economic harm that could follow the shrinking or even collapse of foreign demand for their products. The first round of modern globalization begun in the 1870s ended in the 1930s Great Depression when most economies entered into protectionist modes and faced expanded state roles in economic management of their economies. These efforts proved a prelude to even greater state intervention in firms and markets occasioned by the demands to devote national resources to war efforts in World War II. For the Chinese, the post-WW II civil war pitting Communist and Kuomintang (GMD or Nationalist) forces against other, ended with the Communist establishment of the People's Republic of China in 1949 and the GMD moving the Republic of China to the island of Taiwan where a halfcentury of Japanese colonialism had recently ended with Japanese defeat in WW II. Each carried forward a modern Chinese legacy of state involvement in promoting industrialization.

Chinese governments in 1950 inherited knowledge of the successes and failures of previous Chinese governments in fostering industrialization. They also shared in the general post-World War II ethos of expecting strong governments to lead and develop more prosperous societies. What in other societies were often quite new commitments to popular welfare were for Chinese governments based on political ideas that had a far longer history of institutional development. A basic connection between imperial Chinese ideas about good governance, political economy, and popular material welfare became reconfigured in the ideologies and institutions of development on both sides of the Taiwan straits. This chapter considers the emergence of the state under the Communist Party in the People's Republic of China and considers its vision of transforming society to be fundamental to its domestic political economy. China's domestic political economy in turn provides a vantage point for considering the Chinese state's emergence domestically and internationally.

Many China specialists typically chronicle China's late twentieth-century economic transformation as the country's emergence from the stifling limitations of a socialist planned economy. Some, more typically within China, locate institutional changes beginning in the 1980s within the longer time frame of institutional developments in the first three decades of Communist rule. All students of post-1949 China recognize the dominating role of the Communist party and state in shaping economic and social life through the 1970s and their persistent presence thereafter. We face particularly vexing challenges of considering the possible connections between Chinese approaches to international relations in the world today and its domestic economic 
changes. We know that China's increased economic weight in the global economy portends a continuing evolution of the Chinese state's roles and relationships within the international political system, but do not have many obvious ways of evaluating the ways in which the Chinese state's many institutional actors take on roles enabling and channeling economic change that can inform the ways in which we understand the state's emergence as an international political and economic actor. Looking back on Chinese history can give us some perspective.

Over the first three decades of post-WW II scholarship on modern Chinese history, it was conventional to identify 'modern' Chinese history with the 'opening' of China made possible by the British defeat of the Chinese in the Opium War (1839-1842). More recent scholarship has pushed back the 'modern' era several decades or even to the beginning of the Manchu's Qing dynasty (1644-1911). This historiographical move allowed historians in the last two decades of the twentieth century to highlight domestic dynamics of change that mattered to understanding the conditions of the Chinese state and Chinese society when political, economic, and cultural contacts between Chinese and Westerners became more salient and consequential. Yet, when scholars move forward to the closing two or three decades of the nineteenth century, the main topics of concern remain those aligned along the axis connecting China to foreign interests and impacts. These historiographical choices reflect our own intellectual interests and understanding of the important topics of the period. Certainly, many of the major political and economic figures of the era were busy with a combination of concerns regarding both domestic and foreign affairs. The foreign subjects are most naturally framed within a broader context of the web of contacts defining international relations of that moment in history. Domestic themes are sometimes placed within a historical perspective to evaluate their character in relation to earlier practices.

This historiographical practice for late nineteenth-century China is by no means unusual. It conforms to a more general proclivity of studies that move beyond a particular time and place to move spatially when concerned with international issues and to move temporally when located in the domestic realm. We see the choices that historical actors perceive to be shaped either by earlier practices upon which they can draw or by the systemic links within which they operate and our likely location in time and space of a research subject uses national borders as a differentiating factor. As a result, we are possibly impaired or even potentially crippled when we consider a subject like 'emerging states' since we discover actors across the world who find themselves simultaneously having their own particular paths of emerging and yet sharing a larger more common set of international relations. This is especially the case when we face the openness and uncertainty of present international relations. We are led to wonder in particular how the growing importance of some emerging states globally will more concretely affect the nature of political and economic relations more generally. China is certainly one such state that deserves such scrutiny.

One way to gain some entry into this difficult set of issues is to consider how China's contemporary state has been consciously influenced and perhaps unconsciously shaped by its historical problems and possibilities in order to evaluate at least some of the ways it might be anticipated to act as an emerging state today. 
My strategy of analysis will be to consider concerns in and with China during the decades on either side of the millennial divide from the vantage point of key features of Chinese priorities and policies in the decades on either side of 1800 and 1900. The use of centennial markers is somewhat arbitrary but more easily recognized as such rather than if we use dates with some particular significance of their own which tend to influence perspectives on situations preceding and following the date which elevate the importance of the dates and obscure other significant moments of change or the less vocalized confirmations of past practices. In the next section of this chapter I will briefly consider four fundamental issues informing the ideological character and institutional structures at the beginning of China's modern era around 1800 as a vantage point to consider the contemporary period, roughly the decades on either side of 2000. I will then perform a similar analytical exercise with a move in a subsequent section to consider the pressing problems and priorities Chinese confronted around 1900. The concluding section will address the Chinese state's political and economic emergence as an international actor distinguishing initiatives and activities across world regions observing the ways in which multiple domestic actors and concerns have become enmeshed in China's emerging state with implications for all of us. The consequences will depend on the perceived concerns and results of choices by other actors as well, both those intended and unforeseen.

\subsection{Problems and Persistence of Chinese Empire-Legacies for the Present}

For more than two thousand years rulers on the Chinese mainland built states ruling large expanses of territory with densely settled areas at considerable and even great distances from the imperial center. Thus, the nature of the center's control over far flung locales and regions proved a perennial concern. Historians of China sometimes naturalize the persistent problems of reaching from the imperial court to a myriad of diverse locales because the challenge was chronic. Yet the challenges were historically constructed and reaffirmed over time through the successes of rulers who built new states drawing upon a set of political principles and beliefs reinterpreted and augmented through the centuries and a repertoire of political institutions that created an evolving menu of policy choices from which to select specific responses to issues. Two crucial and related changes took place at roughly the midpoint in this two millennia stretch of empire building and rebuilding after periods of division. The first was the decline of great magnate families based on landed wealth who disrupted Han dynasty rule and emerged after the dynasty's early third-century fall as de facto rulers in many parts of the former empire until the late sixth-century recreation of empire under the Sui dynasty. They remained visible in the Tang dynasty, but by the 10th century transition to the Song dynasty they no longer constituted the kind of threat to central rule that locally powerful families had proved to be in earlier Chinese history and would prove again to be in early modern empires, such as the Ottoman 
and Mughal empires. The second change just beginning to take shape in the tenth century and continuing to evolve for the balance of the imperial era was the formation of a civilian bureaucracy staffed increasingly by individuals who passed exams qualifying them for official posts not located in their province of birth, whose decisions were to be guided by administrative regulations, whose work was reviewed, and who were rotated to serve in different posts in order to reduce the problems of local official identification with local concerns over those of the center. The provincial level of government was consolidated during the eighteenth century so that a vertically integrated bureaucracy with county magistrates serving in over 1300 counties sent reports to the prefect in charge of one several prefectures in a province that fell under the authority of a provincial governor who worked with a provincial treasurer who was from the Ministry of Revenue and was himself subordinated to one of nine governor generals who supervised operations in up to three provinces.

The relations between members of the imperial court, or any other official serving in the capital, with officials serving in the provinces, from the level of governorgeneral down to county magistrate, are today all covered by the same Chinese phrase of 中央与地方关系 typically translated as “central-local” relations. This is the first feature of Chinese governance that informs the manner in which the Chinese state has emerged. This central-local simplification masks the administrative reality of provinces, comparable in size and population to European countries, being considered "local" in relation to the imperial center. When not falling under the general "local" label and noted more specifically as center-province relations, provincial initiatives have often been conceived as a challenge or at a minimum an alternative to the central state exercise of power. But provincial and sub-provincial administrative matters were never completely independent of the center no matter how difficult it proved to be for the center to sustain oversight. If an eighteenth-century Chinese province's bureaucratic capacities and challenges were mapped onto the early modern European scene, we would think, in terms of spatial and demographic scale of England's early modern state making experience as a "local" or "provincial" process, literally de-centering our focus on European state making - allowing us to recognize that what we take to be paradigmatic cases of state centralization in the European age of state building would be nothing more than provincial-level developments in China. While it is easy to see why this kind of distortion destroys our conventional clarity on European developments, we might take a moment to appreciate what the exercise enables us to bring into view from a broader comparative perspective that doesn't immediately default to European norms. At a minimum, we should acknowledge that if the distortions introduced by viewing British political development from a Chinese perspective is deeply disorienting, we should be alert to the dangers of assuming the symmetric exercise of judging Chinese state practices from the vantage point of a paradigmatic European case doesn't limit our view and distort what we are able to observe.

Many of the activities that were pursued within early modern era Chinese counties and bureaucratically coordinated or supervised at the prefectural and provincial levels, such as water control works or granary storage would be viewed as central state activities in a European political context. But in fact such activities, considered com- 
mon and important in China had no clear counterparts in European countries. Water control projects were sparse in Western Europe, the Netherlands of course reclaimed land through their polders and we can find canals built in southern France or dikes maintained in some small German principalities, but even in the few places with water control works, none of them was necessary to agricultural production in the way that controlling sources and flows of water for irrigation were to rice paddy agriculture. From the building and maintenance of irrigation systems up through managing the competing needs for water in rice cultivation and for maintaining water levels in rivers and canals that formed the arteries and capillaries of the transportation infrastructure supporting commerce across the empire, Chinese water control projects were basic and demanding components of the empire's political economy. The Chinese state's civilian granaries were intended to help smooth out seasonal oscillations in grain availability and be a key defense against famine in years of severe harvest failure. An empire-wide system of storage, most of the operations and supervision took place within provinces, with reports of activities part of the communication traffic sent to the center. European countries did not have comparable national systems of grain storage intended to reach both rural and urban subjects. Even a famous effort to address the needs of the poor in times of difficulty, the English poor relief system, lacks the kinds of involvement by the state exemplified by the Chinese granary storage system. Recall that the resources for the English poor relief system were raised locally and not part of any central government budget and that the operation of poor relief was in the hands of unpaid justices of the peace who were local notables, not members of any English bureaucracy entrusted with the task of addressing the needs of the local poor and vulnerable. The British would centuries later develop national systems of welfare funded by tax revenues that would in turn face criticisms mounted among many Western 'welfare states' in the late twentieth century. For the Chinese, subjects like food supply availability and water control would remain political priorities and practical matters involving state interventions after the collapse of the last dynasty and through the different administrations ruling the country before 1949 and in the People's Republic after 1949, however varied the successes and particular institutional arrangements developed to address these matters.

The presence of government policies and practices in late imperial China that did not exist in early modern Europe should make clear to all of us that European paths of state emergence cannot provide an adequate guide for state transformations in China. The Chinese bureaucratic tradition has informed the manner in which the state emerges in our millennium focused upon the people's material welfare as a source for regime legitimacy and establishes the long history behind the acute salience of water management issues in China today. Beyond its substantive agenda, this bureaucratic tradition has a formal feature worth highlighting. In contrast to most all other political systems that distinguish functions, responsibilities, and authority among different levels of government, the Chinese imperial system did so only to a limited degree. Federal systems of government have the sharpest divisions of authority, responsibilities, and functions but even systems that have far less autonomous forms of lower-level government distinguish among the functions of local and central government, as we see in today's France or Japan. In China's early modern era, county 
magistrates were responsible for the same substantive agenda of promoting social order and material security that was articulated by the emperor. As provincial-level government offices became crystalized into a provincial government, its officials still belonged to different central ministries so that duties for various tasks, such as tax collection, were shared by officials both within and outside the Ministry of Revenue and were stationed in both provinces and the capital. These similarities and connections meant the state agenda for material welfare and economic promotion was in some ways pursued at different levels of government in the same or similar ways.

To characterize the late imperial Chinese agenda for state success through fostering local order I have previously spoken of a 'fractal' agenda of rule characterized by the replication of similar features at each level of government (Wong 1997). This trait has implications for how political space is conceived. It encourages people to understand their actions at the local level to serve a far larger political project even when the scale and scope of their activities doesn't reach beyond the county level - this trait helps explain how early twentieth-century advocates of Chinese nationalism could believe that their efforts within a particular province had far less to do with a provincial identity than they did with advancing a national cause. At the same time, it also allowed the replication of similar practices over wide areas to create a set of relatively isolated rural areas held together by few connections beyond the similarity of their practices - a feature of eighteenth-century political economy seeking to settle unpopulated areas through migration and the replication of agrarian economic practices of agriculture and crafts found in well-developed areas of the empire and an even more pronounced proclivity to stress the replication of small and secure agrarian spaces across the country during much of the first three decades of the People's Republic when 'taking grain as the key link' stressed the importance of food self-sufficiency conceived to be relevant at the village, county, provincial and national levels. What separated eighteenth-century economic replication efforts from those after 1949 were eighteenth-century policy efforts to balance population and resources across the empire through commercial movements of grain and crafts and the migration of people from densely populated areas to those with sparser settlements. In the initial years of economic reform beginning in the 1980s, increased movements of people and goods once again became a feature of the economy after some thirty years of government set limitations on commerce and migration. Only since the mid-1990s have efforts to distinguish more sharply between the responsibilities, authority and functions of county, province, and center been pursued by the PRC's state.

I will introduce the remaining three features of the Chinese state c. 1800 far more briefly. A second important feature of Chinese governance c. 1800 was the nature of official relationships to local elites. It too offers an under-utilized perspective on China's emerging state today. Local elites shared with officials a cultural formation through learning the Confucian classics and related texts needed to take, and in only a few cases pass, the civil service exams. This training created a shared (or at least overlapping) understanding(s) of policies and institutions to construct and sustain local social order. To continue with examples of water control and granaries, each had considerable non-official involvement. The management of irrigation networks 
were managed in the first instance by the households whose land used the water for their rice paddies; these very local systems of water management, sometimes limited to households in a single village, were themselves nested within larger water networks that needed separate mechanisms for maintenance and repair. River systems often crossed county borders requiring coordinating the use of resources and labor to repair dikes or dredge river channels; such efforts often brought in county-level officials. Even larger repairs could prompt provincial officials to act_-officials and elites undertook related roles in the management of China's early modern water control systems that were vital to both agricultural production and commercial transportation in ways absent in Europe. The example concerns officials and elites sharing responsibility for granaries. The reserves were reviewed annually by the central government included granaries managed by the county magistrate and for which resources were mobilized by the state as well as those built by local elites who reported their granary activities to their local officials (Will and Wong 1991). The ability, and indeed proclivity, of officials and elites to take on complementary and even substitutable roles in projects designed to maintain or improve material welfare was a basic feature of late imperial Chinese governance. Such features did not mean, of course, that elite and official interests were always congruent or that they did not compete with each other, but they help explain the expectations for complementary efforts, especially in times of crisis, exemplified by local militarization to defend against mid-nineteenth century Taiping rebels, early twentieth-century efforts to suppress opium cultivation and use, and the late nineteenth and early twentieth-century expectations that officials and entrepreneurs would jointly provide capital for new enterprises not according to the anticipation of profits but from beliefs that such investments would strengthen the economy and society.

The logic of complementary roles for officials and elites also represented a balance between the bottom-up initiatives of local elites and the top-down policy priorities of officials. The division between the activities of elites and officials was not sharply drawn in the manner etched in European developments of civil society because the latter were part of a state making dynamic absent in China involving defense against an expanding state presence in society. In early modern China there was both an intersection and positive connection between bottom-up and top-down initiatives but there was also considerable space for local autonomy created by the limits of reach by a bureaucratic state stretching itself across an agrarian empire. After 1949 a Communist-indoctrinated elite emerged who unlike earlier Confucian elites had little to no potential for autonomous action under the strictures of party discipline. With the emergence of new social elites with more than three decades of economic reform, how official-elite relations will become stabilized remains to be seen.

Without the cooperation and commitment of Confucian elites, China's official bureaucracy would have been far less able to achieve the levels of stable governance the state enjoyed when most effective. The third important feature of early modern Chinese governance was its reliance on campaigns to mobilize resources and manpower to undertake large-scale, extraordinary projects (Wong 2001, 2012a). Once again water control and granaries provide clear evidence. Campaigns were mounted to expand granary reserves across the eighteenth-century empire and to respond to 
major river dredging and dike repair projects. Campaigns involved both the coercion of labor corvée and land surtaxes, the persuasion of elites to make financial contributions and manage some of the efforts. Behind the coercion and persuasion was a broader notion of the broader social and political interests of combatting food supply instabilities and maintaining water control works for both production and exchange. The logic of political campaigns is, of course, very familiar to observers of post-' 49 China but not all recognize that political campaigns are not a Communist invention or even just a twentieth-century invention of single party-led states beginning with the Nationalists between 1927 and 1937. Much as the political voice of citizens in modern democracies emerges out of the claim-making institutions early modern European elites and their rulers developed, post-1949 political campaigns and the state that emerges from them built upon earlier political practices.

The combination of a vertically integrated bureaucracy, a coalition of officials and local elites pursuing a shared Confucian agenda for social order, and state mounting of extraordinary campaigns created approaches to state activity that appear in the People's Republic within very different ideological and institutional frameworks. Yet, understanding these features of China's emerging state should benefit from recognizing how they have themselves emerged out of China's past. I will highlight briefly a fourth and final feature of Chinese state institutions and political practices c. 1800 that is sometimes seen as evidence of the Qing empire sharing a semblance with other empires of the early modern era but I suspect tells us at least as much about how Chinese leaders since 1949 have been able to imagine contemporary patterns of institutional diversity within the country's borders (Wong 2005, 2012b). The Qing empire, like other early modern empires, governed its diverse population through separate institutional structures. In the Chinese case, minority populations in the southern half of the empire were sometimes under indirect rule and at other times subject to routine civilian administration. The Manchus and their Mongolian and Han Chinese military allies were organized under eight banners; they established the Lifanyuan (Office of Border Affairs) which combined both military and administrative functions for the Qing establishment of suzerainty over Tibet as well as the management of relations with other Inner Asian groups with whom the Manchus could forge peaceful relations. The Dzungars who were deemed a threat to their achieving a peaceful Inner Asian border region were the object of military campaigns beginning in the late seventeenth century and culminating in their defeat by the Manchus in 1758. Separate from the banners and Lifanyuan were the tributary relations of the Qing with other Asian polities and some of the eighteenth-century contacts between the Qing and Europeans, all of which took place under the Board of Rites, one of the government's six boards first established under the Tang dynasty in the eighth century. Rather than address some of these institutions and suggest their similarity to institutions in other empires, I think we can better understand their significance to China's emergence by recognizing that the full spectrum of institutional distinctions between civilian bureaucratic rule, the banners, the Lifanyuan, and the tributary protocols of the Board of Rites gives us a view of Qing governance spanning domestic and foreign relations. The comparable spectrum for early modern emerging European states would be domestic, intra-European, and the somewhat different 
policies and institutions for governance of colonial territories in the Americas and management of commercial relations in Asia. The binary simplification of modern European political ideology and institutions into domestic/foreign did come to signal some coherent institutional conformity domestically while international relations have remained far less stable institutionally over the nineteenth and twentieth centuries, from the rise and fall of European colonialisms over much of Africa and Asia, the failures of European balance of power principles to prevent two world wars, the binary division of the globe by the Cold War, and the emergence of international institutions that have either regional or global activities. The Chinese state today emerges with domestic distinctions between areas deemed 'autonomous' because of an earlier set of governance practices both across its Inner Asian frontier and among areas within China proper where minority populations predominate.

The four features of Qing governance c. 1800 help to explain the kinds of capacities and commitments the Chinese state had fashioned in earlier times to base its political legitimacy on achieving social stability through promoting agrarian economic prosperity in a commercial economy spanning urban and rural locales. These capacities alert us to some of the reasons the Chinese state was able to survive the nineteenth century when the international political and economic contexts within which it had to operate presented new challenges and fostered the construction of new ideologies.

\subsection{From Empire to 20th-Century State-Power and Wealth, Party and State}

For several nineteenth-century states, including Asian countries such as Japan, Korea, and Thailand as well as far larger states such as the Ottoman, the Qing, and Russian empires, the examples of Western European and American economic growth and building of strong states offered models worthy of emulation in order to compete more effectively with them in a world of increasing economic connections and political ties. In the Qing case, so-called "self-strengthening" included the formation of new central government institutions to engage Westerners. Many of the officials responsible for mounting important new projects did so from positions within the bureaucracy that placed them outside of the capital. An earlier generation of scholarship suggested that these regional leaders were expanding their powers resulting in a devolution of power from the center to provincial leaders. Yet a leader identified as regional could also represent the Qing state to negotiate treaties, as Li Hongzhang did, both with the Koreans and with the Japanese, for state purposes and not envisioned to develop the economy in any clear manner. Li Hongzhang and other late nineteenth-century officials lived in a Chinese political order built upon a fractal vision of similarities of political intent no matter what the spatial frame of the efforts might be. He did not see his successes (and failures) as other than those of the dynasty itself. Thus, the structural challenge of coordinating efforts at different levels or parts of a bureaucratic 
system can be distinct from the more particular issue of constructing integration based on a division of labor defining different interests and thus potential competition among segments of the system. Individual officials could see themselves as serving imperial and subsequently national interests even if their ambit of authority was regional or local and not central.

Many of the efforts to strengthen the dynasty through military and industrial projects were undertaken by officials with provincial positions. Even if specialists come to recognize more generally that the Chinese pursuit of self-strengthening was conceived with the intent to sustain the state more generally, few are yet ready to consider whether or not such efforts also came to embrace older commitments. Scholars have typically viewed self-strengthening as a particular and focused movement to address new challenges, yet the pursuit of wealth and power by the 1900 included an understanding of "industry" (工业) to include the introduction of new machinery into rural handicraft settings, such as an iron gear loom for textile weaving. A survey of Jiangsu province published in 1919 summarized economic activities by county. This study included under “industry' machines used in rural household industry - even as Jiangsu was site to some of the important urban factory production emerging in China, "industry" as a category included the changes to rural handicraft production and not only the factories that would one day replace them. This Chinese notion of "industry" briefly brought rural craft transformation into its coverage, but did not survive into the 1930s. From that decade through the 1970s "industry" largely referred to more urban-based capital-intensive factory production. But beginning in the 1980s a dramatic rise in rural industry, the "township and village enterprises" (TVE, 乡镇企业), were a major source of industrial growth well into the 1990s. While certainly not handicraft industries, these rural industries were also not the stereotypical large urban-based capital-intensive factories using the latest and most advanced technologies. Nor were they the kinds of industries that were promoted under the socialist planned economy. Fitting neither economic models of modern economic growth or a socialist system, they can be more easily seen to resonate with earlier logics of how to incorporate industry into even older notions of promoting material welfare of the common people (Wong 2002, 2014). The Chinese state's emergence in the economic reform era included filling in the rupture between urban and rural sites of industrial production created under the socialist planned economy.

Returning to the vantage point of the Chinese state c. 1900, the standard political narrative recounts the failures of the last massive push for reforms, the New Policies, which set up new ministries modeled on those of Western countries and the termination of the civil service examination system. A weak republic with competing centers of power and authority emerged in provinces after 1911—some regimes were led by military leaders and others by coalitions of civilian elites attempting to build new institutions (McCord 1993). Some of the regimes, perhaps most notably that of Yan Xishan in Shanxi also made plans for economic development during the warlord era after the fall of the Qing in 1911 (Gillin 1967). Such projects were less seen as competitive efforts akin to those undertaken by mercantilist governments in early modern Europe and more as complementary strategies for building economic strength, the better to enable "China" to stand up politically to foreign pressures. 
In cities, industries before the Japanese invasion of 1937 were basically a private sector development that brought together foreign and domestic capital, foreign and domestic managers, and Chinese labor to create mainly light industrial consumer goods, including flour, cooking oils, cigarettes, and matches. Such developments did not stop Chinese governments from envisioning grander plans for large-scale government-led projects. But even the GMD's Nationalist state during its period of most effective rule in the decade after 1927 achieved little beyond blueprints. The mindset however proved persistent. The wartime political crisis forcing the Nationalist government to flee inland to Chongqing included the remarkable physical movement of large amounts of machinery and the assertion of control over previously private enterprises by the government in the name of wartime emergency. After losing their post-WW II civil war with the Communists, the Nationalists did not persist in controlling industry as they had during wartime, but that aspiration informed Communist Party thinking as they began industrialization plans after coming to power on the mainland after 1949. Their first goal was to recover from the economic dislocations caused by war and to this end they supported private Chinese entrepreneurs whose efforts to build a new China was crucial since they possessed the expertise and the resources to contribute to economic recovery. An implicit and somewhat politically uneasy relationship between state and industrial entrepreneurs was replaced in the second half of the 1950s by collectivization of agriculture and nationalization of industries, making both sectors subject to state planning processes. What had been a tacit willingness of the Communist party-state to work initially with industrial entrepreneurs was replaced by a heightened concern for the kinds of classes that the party state wanted to exist in the new socialist society. Within this set of concerns, the Communists made industrialization a party-state project to be pursued without a bourgeoisie. This led to the subtraction of a private class and the construction of a public class of cadres who would become in the second half of the 1960s the 'capitalist roaders' of the Cultural Revolution.

Those who suffered the label of "capitalist roaders" were members of the party's elite that replaced the Confucian elite staffing the Qing state c. 1800. That Confucian elite had already been shown inadequate to meet the demand for the concrete skills needed to guide the country successfully into century in the pursuit of wealth and power. But the new elite could not merely be technocratic-the search for an ideology or vision to replace the Confucian agenda for rule became tied to the organizational centrality of the Communist Party as the creator of a new political elite to replace the previous social elites of Confucian scholars, entrepreneurs and landlords. The formulation of a new socialist China created a party-state led construction of national identity that assumed a Chinese people with a long cultural history and focused on building a modern society utilizing advanced technologies. Beneath this vision of a common forward moving economic progress were realities of economic differences between urban and rural China as well as economic differences among different regions of China. The Chinese state was certainly aware of the regional differences c. 1800 as well as c. 1900; by the latter date the possibilities of growing gaps between urban and rural sectors began to come into focus, encouraging a capacious understanding of "industry" and then by the 1930s separate initiatives to develop 
the urban economy and revitalize the rural economy before the Communist state formally separated institutionally urban and rural China and managed each through its party-state bureaucracy.

The political economy of 1950s was different from what preceded it not simply because a socialist state institutionally modeled on Soviet Russian political institutions was put in place. It was also significantly different because what had been a vibrant agrarian commercial economy that linked rural and urban China was largely dismantled by the mid-1950s. At the same time society was simplified-the forms of associational life that had developed in twentieth-century urban China as well as the far older kinds of associational life in the countryside were all dissolved or at least stripped of their purposes and given no social space within which to operate. Only associations and organizations under Party supervision were permitted. Social simplification made organization of society by the party state feasible in ways that were otherwise inconceivable. Most all of social life was channeled through institutions directly run by the party-state or supervised by the state-what had previously been a shifting late imperial equilibrium between officials and elites sharing elements of a common agenda became a party-state led agenda for political transformation. These changes in turn made the potency of political movements far greater than they were earlier in the twentieth century, let alone c. 1800. The party state that emerged after 1949 clearly chose to depart from practices of the state in 1800 , even if much of such movements did not recognize the changes to be mounted from conditions resembling those of the country's historical past. These changes tend to obscure other ways in the PRC state in the 1950s also faced challenges common to the state c. 1800, in particular how to organize center-region/locale relations and how to promote popular material welfare.

Most institutional changes in the countryside involved increasing levels of collectivization culminating in the formation of communes followed by decreasing levels of collectivization culminating in the return to household-state relations as akin to late imperial practices as they were to previous Communist ones. A related set of changes took place regarding management and control of industries in which different levels of administration below the central ministries began in the mid-1950s to control state owned enterprises. Through the 1970s, agriculture and industry were all organized administratively with the division of authority between central, provincial and local authorities being the axis along which reforms were carried out. The late twentieth-century economic reform era included enterprise formation outside the socialist plan and increased use of markets in both urban and rural areas. By the 1990s the state's challenge to tap the growing wealth of the economy led to experiments with reorganizing the country's fiscal system culminating in a major round of reforms in 1994 from which different fiscal bases for different levels of government were recognized along with shifting sets of public responsibilities associated with each level. Bureaucratic change followed economic change. The particular characteristics of the Chinese state's fiscal system emerged out of previous practices as much as it involved the adoption of foreign practices.

However great the institutional changes in Chinese political economy by the new millennium, the state still sometimes invoked its aspirations to achieve wealth and 
power. The pursuit of wealth continues to have a strong connection to issues of distribution and raising material standards of living for the population at large. The pursuit of power continues to include domestic as well as foreign dimensions. The international dimensions of the pursuit of power truly have emerged more fully since c. 2000. In retrospect, China's separation from a U.S. dominated system of international relations for three decades after 1949 may well have been a blessing. Certainly this reduced the political challenges and demands on state. The reform era's international opening to gain access to capital and technology made it possible for Chinese labor to produce for export markets and the Chinese economy subsequently to begin to invest capital overseas in the new millennium. Chinese entrepreneurs and state organized projects have become sources of benefit and contention in African and Latin American countries. China has become an emerging state that will influence the future evolution of global political and economic relations.

\subsection{China and Other World Regions, Globalization and Global Hegemonies}

President Xi Jinping began in the fall of 2013 to discuss a Silk Road Economic Belt and a Maritime Silk Road with leaders in Central Asia and Southeast Asia. These became combined in the phrase "One Belt One Road" in 2014 with the intent to invest in infrastructure, production and trade in locations in Asia, the Middle East, Africa and Europe. At the economic heart of OBOR has been the promise of billions of dollars of infrastructural investment to undergird new transportation networks to move natural resources, agricultural crops, and finished goods along new and improved routes. The "belt" refers primarily to overland routes through Central Asia where natural resources of great interest to the Chinese (and others) are located. It is projected to extend along new rail line networks to be built to cut transportation costs from China to European markets. These rail lines complement the port facilities that China has developed in the eastern end of the Mediterranean in Greece's Piraeus. The "road" refers to maritime routes intensified and extended through new port developments, especially within Asia.

These developments promise a major response to the Asia Development Bank's 2009 report calling on Asian countries to invest in their transportation infrastructures some $\$ 8$ trillion dollars between 2010 and 2020 (Asian Development Bank 2009). The ADB called on Asian governments to make these huge infrastructural investments in order to give their populations improved access to market opportunities and also commit an additional \$290 billion dollars in regional infrastructure and energy projects. The call was made with little sense of how Asian countries could effectively revise their fiscal capacities to enable such outlays of capital, how to tap international capital markets, or to improve upon the ways large infrastructural projects have had uneven success. Large-scale infrastructure projects have become "PPP" efforts (public-private partnerships)—complex projects divided into public 
and private sector components, through which businessmen invest in the components they expect to have financial returns and states to support the financing of those necessary developments that have no likely financial return. Huge in scale and complex in division of labor they require multiple kinds of negotiation and agreement among public and private actors and have proven vulnerable to delays and even suspensions of activities, as they have to fit within shifting political climates in the country where such projects are launched as well as meet the financial expectations of private sector investors, not to mention the often daunting engineering tasks they entail.

The Chinese state's emergence internationally through OBOR represents new departures into international relations guided by past experiences and with the intention of creating new alternatives to the status quo conditions in the global economy. OBOR represents both an extension and a revision of Chinese approaches to economic development in poorer peripheries of their own country. It is a revision because unlike earlier efforts to build peripheral economies to make them more productive on their own or to link them more closely with the interior, cross-border infrastructure projects seek to tap commercial potential from extending economic integration of China's peripheries to its foreign neighbors-in Central Asia this is certainly to tap Central Asian natural resources and follows some of the kinds of projects China embarked upon in Africa. In southwestern China with its cross border connections to Southeast Asia the developments appear more geared to broadening and deepening market integration to create mutual benefits through trade and can also be seen as an extension of the principles of market expansion long pursued domestically by the Chinese.

OBOR infrastructural projects also represent a revision of Western approaches that until recently distinguished between government aid, international loans, and private sector projects. Now the so-called PPP bring together institutionally discrete actors to divide large projects into smaller sections subject to different criteria of desirability. Western approaches to aid have varied over the past half century and there remain major differences of opinion regarding the most sensible basic orientations to creating positive material improvements in the quality of poor people's lives. The best development thinkers and practitioners recognize that multiple methods can have constructive impacts in certain circumstances. But they also realize that mistakes or negative unintended consequences have attended aid projects large and small. At the risk of caricaturing important figures in development studies we can consider Columbia University economist Jeffrey Sachs' promotion of development through massive infusions of aid, call for effective standards of governance, and frequent role as advisor to the UN and government leaders a leading example of a long tradition of top-down and foreign-native knowledge transfers intended to create conditions for economic growth (Sachs 2012). In striking contrast is former World Bank economist William Easterly also based on the island of Manhattan at New York University who rails against the tyranny of development experts who have shouldered their white man's burden as they descend on poor countries around the world prescribing remedies for their poverty (Easterly 2002). He counsels the importance of empirical knowledge of specific situations and the recognition that 
functional market institutions cannot be imposed from above but must be nurtured within society to become effective. How do Chinese approaches to OBOR projects compare with current understandings of development strategies in the West?

In China's domestic economic reform strategy a combination of bottom up and top down efforts were implemented. This is clear in the example of township and village enterprises. The central government set loose guidelines in the early 1980s to allow diverse forms of township and village enterprises to develop. The initiative to develop these enterprises rested with county-level officials and local entrepreneurs. The environmental damage done by largely unregulated industrial development subsequently led to more top-down regulations and controls over these factories, many of which were subsequently put out of business by increasing market competition. An initial comparison of these Chinese practices with Western views suggests Chinese implementation of Sachs-like infusions of policy with Easterly-like recognition that market principles had to enjoy some local basis in practice. Upon reflection one can see that the Chinese did not however adhere to principles that Sachs, Easterly, and most other Western economists and analysts more generally take as necessary-basic principles of governance associated with democratic practices. The World Bank's Worldwide Governance Indicators, for instance, provides a metric based on survey responses of business people working in different countries regarding issues including the rule of law, effectiveness of bureaucracy, and the degree of corruption (Kaufmann et al. 2011). Unless countries score well on these and related topics they are deemed less likely to use World Bank loans productively. This logic conforms to the policy prescriptions Nobel laureate Douglass C. North drew out from his studies of American and British economic history that economic growth takes place when and economy and government have the proper institutions. His version of new institutional economics created a causal sequence of growth coming from the prior existence of good institutions - in terms of this book a proposition that economic development only occurs after a state modeled along the lines of AngloAmerican institutions emerges. The Chinese experience historically and beginning anew in the late twentieth century has undermined empirically this form of argument since much of the economic growth and development of the 1980s took place without effective courts or contracts, let alone the kind of democratic political system deemed necessary for an open society with freedom of opportunity. Instead, the Chinese developed Western-style institutions as the complexity of their economic transactions and engagement with global partners made such changes desirable. The direction of the causation between Western-style economic institutions and growth is crucial to understanding how China's state fostered development. It did not do so by emulating Anglo-American institutions generally. In economic history we can find examples of changes in the real economy stimulating changes in financial markets (France) and in the neighboring country of Germany scholars suggest that the development of banking institutions enabled Germany's late nineteenth-century economic growth. One might have expected that as economies become more complex, countries starting from a more backward position would need more upfront investment in institutional frameworks as well as actual capital being applied either from outside sources and/or top down sources, an expectation related to Gerschenkron's 
1962 arguments about the importance of states to overcoming economic backwardness (Gerschenkron 1962). Yet, the Chinese experience suggests that this is only partially true. Also important was building on existing (or in the Chinese case earlier subsequently suppressed) practices that allow market exchanges to function.

How might China's emerging state's domestic political economy affect its approach to international economic and political relations? First, the Chinese are less troubled by conventional signs of poor governance and hence poor investment risk than are Western companies, governments, or int'l organizations. There are disagreements, to be sure, in China over the manner in which OBOR projects are being drawn up and some analysts are far closer to Western norms than others. But projects are both planned and in process that would be deemed too risky by other international actors. The Chinese state's emergence thus suggests a challenge to prevailing norms or at least a challenge to reconsider their logic and effectiveness. The Chinese approach in OBOR projects seems at times to affirm a proposition present in ancient Chinese political philosophy and in centuries of Chinese economic policy formulation-address people's material welfare conditions to achieve political legitimacy and success (El Amine 2015). Rather than making political stability a precondition for economic development, Chinese OBOR efforts at times appear to propose economic development as a precondition for political stability. The idea is also present in the Western thinking that stresses the importance of creating jobs and a productive economy to ameliorate poverty in contentious political situations but the principle has not received the scale resources backing up Chinese initiatives.

The number and scale of Chinese developmental projects are both so large that some are unlikely to succeed. But if the state's approach to international economic relations emulates China's domestic economic reform efforts, then there will be repeated adaptation to each round projects by formulating revised policies aimed at achieving goals not reached under the previous round. Even if Chinese "learning by doing" doesn't operate in the same way internationally as it has domestically, as long as some developmental successes occur, a second set of issues regarding the impact of economic changes on geopolitical conditions becomes important. Here the issue is the complex way in which global political and economic systems historically and today operate with complicated mixes of cooperation and competition.

The early modern European expansion into other world regions introduced the use of violence into economic as well as political relations as Europeans staked out claims to land in the Americas and established ports at which to trade in Asia. As a result the pursuit of wealth and power by competing early modern European states created intimate connections between a European state's political success and its economic wealth. The nineteenth-century emergence of Britain as the world's hegemonic power emerged from that historical context; the British created a significant economic and military gap between itself and other countries to allow it to make itself the first modern hegemonic power and its government defined the terms of emergence as an effective modern state for others as its economy became the first in the world to industrialize and be taken as a model by others. The United States displaced Britain peacefully as the hegemonic power in the twentieth century, but only after a period of two world wars caused by political competition in Europe. 
Post WW II American hegemony did not span the world because organized competition and resistance to its hegemony came from the Soviet Union. The Cold War was possible because the Soviet bloc countries were largely separated from Western economies. As economic globalization has forged ever greater connections among countries across different world regions and we have seen in the past half century Asian examples of rapid economic development, the possibilities of one state establishing a hegemonic position over such a system seems less likely than it had been in previous centuries. The issue of China's economic and political rise is therefore not simply an issue of its competition with the U.S. for the spot of hegemon, but rather a new global challenge created by the transformed economic architecture of the world that makes earlier logics of pursuing wealth and power less positive and constructive than ever before. The Chinese state's emergence calls into question the conventional metrics based on Euro-American experiences for defining normal states and this state's role in transforming its own economy and economic prospects of other countries suggests that the intellectual challenge of understanding emerging states is also a policy imperative to revise and perhaps even reformulate some of the principles and practices of international political and economic relations.

\section{References}

Asian Development Bank and Asian Development Bank Institute. (2009). Infrastructure for a Seamless Asia. Asian Development Bank.

Easterly, W. (2002). The Cartel of good intentions: The problem of bureaucracy in foreign aid. Journal of Policy Reform, 5(4), 223-250.

El Amine, L. (2015). Classical Confucian political thought: A new interpretation. Princeton: Princeton University Press.

Gerschenkron, A. (1962). Economic backwardness in historical perspective. Harvard: Harvard University Press.

Gillin, D. (1967). Warlord: Yen Hsi-Shan in Shansi Province. Princeton: Princeton University Press.

Kaufmann, D., Kraay, A., \& Mastruzzi, M. (2011). World governance indicators: Methodology and analytical issues. The Hague Journal on the Rule of Law, 3, 220-246.

McCord, E. (1993). The power of the gun: The emergence of Chinese warlordism. California: University of California Press.

Sachs, J. (2012). From millennium development goals to sustainable development goals. Lancet, $379,2206-2211$.

Will, P. E., \& Wong, R. B. (1991). Nourish the people: The state civilian granary system in China, 1650-1850. China: University of Michigan Center for Chinese Studies.

Wong, R. B. (1997). China transformed: Historical change and the limits of European experience. New York: Cornell University Press.

Wong, R. B. (2001). Formal and informal mechanisms of rule and economic development: The Qing Empire in comparative perspective. Journal of Early Modern History, 5(4), 387-408.

Wong, R. B. (2002). The political economy of Chinese rural industry and commerce in historical perspective. Etudes Rurales (Le retour du marchand dans la Chine rurale), 161-162 (janvier-juin): $153-164$.

Wong, R. B. (2005). China's Agrarian empire: A different kind of empire, a different kind of lesson. In C. Calhoun, F. Cooper, \& K. W. Moore (Eds.), Lessons of empire. 
Wong, R. B. (2012a). Taxation and good governance in China, 1500-1914. In B. Yun-Casalilla, P. K. O’Brien, \& F. C. Comín (Eds.), The rise of Fiscal States: A global history, 1500-1914. Cambridge: Cambridge University Press.

Wong, R. B. (2012b). Reflections on Qing institutions of governance: Chinese Empire in comparative perspective. Crossroads, 5, 103-114.

Wong, R. B. (2014).近代早期到近現代的中國：比較並連結歐洲和全球歷史變遷模式 From early modern to modern China: Comparing and connecting to Europe and global historical transformations. Router: A journal of cultural studies, 19, 18-57 [in Chinese].

Open Access This chapter is licensed under the terms of the Creative Commons AttributionNonCommercial-NoDerivatives 4.0 International License (http://creativecommons.org/licenses/bync-nd/4.0/), which permits any noncommercial use, sharing, distribution and reproduction in any medium or format, as long as you give appropriate credit to the original author(s) and the source, provide a link to the Creative Commons license and indicate if you modified the licensed material. You do not have permission under this license to share adapted material derived from this chapter or parts of it.

The images or other third party material in this chapter are included in the chapter's Creative Commons license, unless indicated otherwise in a credit line to the material. If material is not included in the chapter's Creative Commons license and your intended use is not permitted by statutory regulation or exceeds the permitted use, you will need to obtain permission directly from the copyright holder.

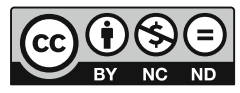




\title{
Chapter 6 \\ A History of the Indian Economy \\ in Asian and Global Contexts, \\ 1810s-2010s
}

\author{
Sugata Bose
}

\begin{abstract}
A grim temporal trajectory unfolded in the course of the nineteenth century in terms of the great divergence in the economic fortunes of Europe and Asia. Contrary to popular misconceptions, there was nothing ancient about Asia's poverty. The decade of the 1810s was a watershed during which Indian artisanal products lost their ability to compete in the global marketplace. China tea replaced Indian textiles as the most valuable commodity in the Company's trade, increasingly paid for by Indian opium rather than New World silver. The early twenty-first century is emerging as the moment of re-convergence with some prospects of Asia outstripping Europe and the West on key indicators of economic performance. This chapter narrates and explains the economic decline and rise of India during the preceding two centuries in a comparative and connective Asian and global context. It offers a careful account and explanation of different phases of poverty and prosperity.
\end{abstract}

\subsection{Introduction}

A grim temporal trajectory unfolded in the course of the nineteenth century in terms of the great divergence in the economic fortunes of Europe and Asia. Contrary to popular misconceptions, there was nothing ancient about Asia's poverty. In a pathbreaking book titled Asia before Europe, Chaudhuri (1990) documented and analyzed the economic dynamism of Asia and the Indian Ocean world in the period until 1750. Before 1800, in Pomerantz's (2000, pp. 9-11, 17) view, there was “a polycentric world with no dominant center". He stresses the proximity of fossil-fuel energy and the contingent availability of New World resources in explaining the European breakthrough. Parthasarathi (2011, pp. 1-2) notes "profound similarities in political and economic institutions between the advanced regions of Europe and Asia" until the late eighteenth century. In his analysis, two pressures-the competitive challenge of Indian textiles and shortages of wood-generated the process of

\author{
S. Bose $(\varangle)$ \\ Department of History, Harvard University, Cambridge, MA, USA \\ e-mail: sbose@fas.harvard.edu
}


the British industrial leap forward. Probing why Europe grew rich and Asia did not, he pinpoints the early decades of the nineteenth century as the moment of the global economic divergence. The early twenty-first century is emerging as the moment of re-convergence with some prospects of Asia outstripping Europe and the West on key indicators of economic performance.

The year 1813 saw a revision of the charter of the English East India Company withdrawing its monopoly to trade with India and marking a triumph of the advocates of free trade over the mercantilists who had held sway in the eighteenth century. The decade of the 1810 s was a watershed during which Indian artisanal products lost their ability to compete in the global marketplace. China tea replaced Indian textiles as the most valuable commodity in the Company's trade, increasingly paid for by Indian opium rather than New World silver. The decade of the 2010s may represent the close of a temporal cycle and the opening of a new one with manufacturing and financial clout shifting back to Asia.

\subsection{The Era of Opium and Indigo, 1810s-1850s}

Without control over Indian territories the English East India Company would not have been able to survive for half a century after the loss of its Indian trading monopoly. It had access to India's land revenue, a process that had begun with its acquisition of the diwani of Bengal in 1765. Control over the land revenue of Bengal had obviated the need to bring in silver to pay for Indian textiles. From the second decade of the nineteenth century Indian textiles lost out in world markets to the manufactures of England's industrial revolution. The Company met its requirement of remittances to the metropolis through the forced cultivation of indigo and financed its China tea trade by establishing a government monopoly over opium cultivation in India. Massive illegal sales of Indian opium in China made it unnecessary for the company to bring in silver to finance their purchase of tea. The opium monopoly provided about fifteen per cent of the income of the company state, and accounted for nearly thirty per cent of the value of India's foreign trade until the mid-1850s.

The number of chests of opium imported from India into China rose from about 4570 in $1800-1801$ to more than 40,000 chests in $1838-1839$ on the eve of the outbreak of the Opium War (Trocki 1999, p. 94). The East India Company had the dubious reputation of being by far the largest corporate drug dealer in the world during the first half of the twentieth century. The Company found willing Indian collaborators, especially among some Parsi traders, who helped transport opium from the hinterlands of northern and central India to the ports of Bombay and Karachi and from there by sea to China through Southeast Asia. In Southeast Asia, the Chettiar capitalists from Tamilnadu began their operation in the 1820 s by selling cotton piece goods from the Coromandel coast. But the real breakthrough for Tamil capital in the Straits came with a waft of fragrant smoke and a whiff of notoriety. The most prominent among the Parsi opium dealers was Jamshetjee Jeejeebhoy who worked hand in glove with William Jardine and James Matheson ever since a chance encounter 
between Jeejeebhoy and Jardine on board a ship in 1805. "Hong Kong and opium," writes Fay (1997, p. xiv) of the situation in 1840, "the place, the British, the drug. A natural, deadly three-way symbiosis."

Between 1808 and 1856 as much as \$ 384 million worth of silver flowed out of China as opium paid for Chinese tea that accounted for $85 \%$ of the world's exports of the commodity until 1871. In the early nineteenth century Latin America, especially Mexico, served as the source of silver. The dislocations caused by the Latin American independence movements resulted in a drop in silver and also gold production after 1811. Taking account of this global context, Man Houng Lin has claimed that "the British could not find enough silver to pay for tea and silk and ended up using opium as the medium of exchange for them". A close study of the deliberations in the British Parliament leading up to the revision of the Company's charter in 1813 reveals, however, that the decision not to pay in silver for Asian commodities was very much part of "the calculations, strategies, forms and practices of imperial rule". Lowe (2015) has brilliantly brought to light the intimacies of four continents-America, Europe, Asia and Africa-by showing the connections between African slave labor in the cotton fields of the US South, textile production and design in Asia, and the tea and opium trades of India and China in the making of British "free trade imperialism". The great divergence cannot be explained merely by reference to proximity of fossilfuel energy resources or the New World windfall for Europe. A connective history reveals the critical importance of the colonial conquest of India and the opium trail that led from India to China.

The colonial state was directly embroiled in the production and trade in opium. Its involvement with indigo was indirect through the setting up of financing mechanisms and bolstering of the power of European indigo planters, but quite as significant. Peasants were initially tempted with the money advance that came from indigo planters, but after 1830 indigo became a forced cultivation by an indebted peasantry. The early nineteenth century was a blue phase in dressing for European war and fashion. The dye drawn from the indigo plant grown in Bengal and Bihar, therefore, had a buoyant market in the West. There was an intra-Asian dimension to the indigo trade as well with significant markets in West Asia, especially Iran, and Central Asia. A mere $4 \%$ of the indigo production was locally consumed. The average annual value of indigo exports from Calcutta rose from Rs. 4 million in the decade 1796-1805 to Rs. 21 million during 1836-1845. The "blue mutiny" by peasants in 1859-60 brought the indigo system to an end in Bengal, but a different configuration of class forces ensured its continuation in Bihar until World War I (Bose 1993, pp. 45-51; Nadri 2016).

Opium and indigo were commodities of critical importance in the global economy of the first half of the nineteenth century and had key connections with the forms of servile labor that rose to prominence from the 1830s onwards. At one level, indentured and 'apprentice' labor and to a lesser degree convict or penal labor may be seen to have filled the breach in the plantation sector left by formal abolitions of slave trades and slavery. Yet there was something else of immense significance for the nineteenth-century world economy going on in the agrarian hinterlands of Asia. What was fashioned in the first half of the nineteenth century was a settled and 
sedentarized peasantry, which during its latter half produced primary products for a capitalist world market. "The first half of the nineteenth century," Bayly (1988) has argued, "was a critical period of the formation, by hammer blows from the outside, of the Indian peasantry." The colonial state held wandering peoples without fixed addresses in deep suspicion. The mobility that characterized eighteenth-century rural society was replaced in the nineteenth with the immobility and stern discipline of agricultural commodity production.

\subsection{The Era of Classic Colonialism, 1850s to 1920s}

India, the homeland of cotton, came to be inundated with cotton manufactures from Britain only from the 1850 s onwards. This was the period when India along with much of colonized Asia served as a vast market for Western manufactured products, especially British textiles, and the source for a wide array of agricultural raw materials. Raw cotton, raw jute, tea, coffee, oil-seeds, wheat and hides and skins were the chief exports of colonial India in the late nineteenth and early twentieth centuries. Cotton and jute were cultivated on peasant smallholdings in western and eastern India respectively while tea and coffee were grown on mainly European-owned plantations in Assam, Darjeeling and southern India. Sugihara (2013) has depicted this period as one of labor-intensive industrialization in East Asia, especially Japan. South Asia, by contrast, witnessed a process of labor-intensive commercialization of agriculture in this era. Peasants in the cotton and jute tracts switched to higher-value and more labor-intensive cash-crops. Unlike Japan, cottage industries did not flourish in the rural sector and there was no effort to improve the quality of labor through formal schooling or otherwise. At the end of colonial rule in 1947 a mere $13 \%$ of the Indian population had basic literacy - a smaller proportion than at the onset of colonial rule in the late eighteenth century.

The social organization of agrarian production in colonial India rested on a labor process utilizing the unremunerated and grossly under-remunerated work of family labor. Expanded commodity production for the capitalist world market was achieved efficiently and cheaply without resort to the formal commodification of labor. The refusal to be reduced to a commodity was itself a success of resistance by peasant labor determined to retain access to a combination of production-based and tradebased entitlement to consumption and subsistence. Western banks played a major role in the financing of Asian agrarian production and trade. From the late nineteenth century onwards, the surplus produced by peasant labor was extracted largely through the economic circuits of debt at the end of the production cycle. But this had to be tempered by the sharing of the responsibility for assuring subsistence and minimal needs of peasant labor through adequate provision of credit by the owners of land and capital at the beginning of the production cycle. It was the lines of credit that tied together the domains of land, labor and capital, and geared agrarian society to undertake production that sustained colonial commerce. Over the long term, agrarian society 'peasantized' during the early nineteenth century may be seen to 
have fought a drawn-out rearguard action contesting and warding off the tentative forces of 'depeasantization' since the late nineteenth century. The human and social costs of the contradictions between capital and labor can be gauged by the direction of change in otherwise resilient social structures - the downward spiral of pauperization, the slower but significant shift in favor of demesne lords and a richer peasantry, and the subtle change in gender and generational roles to the disadvantage of women and children. The development of colonial capital resting heavily on peasant family labor meant the forcing up of the intensity of unpaid and underpaid women's and children's labor. Peasant labor clung on to the basic means of production-land-but became increasingly dependent on merchant and usury capital (Bose 1993).

Yet this was also an era of Asians on the move and new sets of intra-Asian connections were forged based on the specialized flows of capital and labor, skills and services, ideas and culture. Production relations based on settled peasant labor and migrant indentured or quasi-indentured labor were bound in a dialectical relationship. In East Asia, intra-regional trade flourished in this period, especially between Japan and China. In South and Southeast Asia, it may have been possible until the mid-nineteenth century to advance a simple demographic typology of densely populated and sparsely populated zones. The rise of plantations and mines dramatically unsettled that dichotomy. They drew their labor from the old-settled thickly populated agrarian regions, which got an extended lease of life through this escape-hatch of migration. Large contingents of Tamil labor, for instance, moved to the tea plantations of Ceylon and the rubber plantations of Malaya, just as Chinese migrant laborers were set to work in the tin mines of the peninsula. But the new concentrations of population also needed new sources of food, which the old rice bowls of Bengal, Tamil Nadu, Java and northern Vietnam were in no position to supply. This spurred the opening of the rice frontiers of the Irrawady delta in Lower Burma, the Chao Phraya delta in Thailand, and the Mekong delta in southern Vietnam largely financed by overseas Chinese and Indian capitalists. The triad of old agrarian zones, new plantations and mines, and newer rice frontiers linked by specialized flows of labor and capital remained in place from the mid-nineteenth century until the crisis of the depression decade arrested or reversed most of these flows (Baker 1981).

The labor-intensive commercialization of agriculture did not create conditions for sustained prosperity. There were short periods of boom, for example, in the cotton tracts when the civil war of 1861-1865 cut off supplies from the United States. The economic downturns of the 1870s and the 1890s exposed the vulnerabilities of the Indian agrarian economy. A series of terrible famines occurred in the late $1890 \mathrm{~s}$ and the turn of the twentieth century, that devastated the peasantry in the cottongrowing regions of western India. A premier British medical journal, The Lancet, estimated famine mortality in India during the 1890s at 19 million which was about half the population of Britain. The death toll for the 1897 famine ranged from the official figure of 4.5 million to unofficial claims of up to 16 million. These were the severest of the many "late Victorian holocausts" (Davis 2000). In 1900 the Viceroy, George Nathaniel Curzon, tried to pass off a severe problem of political economy as a problem of nature. In 1902, he claimed that "to ask any Government to prevent the occurrence of famine in a country, the meteorological conditions of which are what 
they are here and the population of which is growing at its present rate, is to ask us to wrest the keys of the universe from the hands of the Almighty". This view was effectively contested by Romesh Chunder Dutt and Dadabhai Naoroji, who squarely blamed colonial fiscal and financial policies for these man-made disasters. In eastern India, a short-lived boom in the jute economy between 1906 and 1913 was swept away at the onset of World War I (Bose 2008; Ali 2018).

From 1870 to 1914 India's export surplus based on raw material exports was critical in offsetting Britain's deficit in the international system of trade and payments. The transfer of funds from colony to metropolis through a variety of mechanisms and for a variety of purposes led Indian nationalists to charge that there was a systematic "drain of wealth" from India. The devaluation of India's silver-based currency between 1873 and 1893 increased the burden of payments to the gold-based metropolis. While Indian capital made a move from commerce to industry in western India during the latter half of the nineteenth century, the establishment of a factory-based cotton textile industry in Bombay and Ahmedabad did not quite enable India to catch the second bus to industrialization along with Japan, Germany, Russia and the United States. The Lancashire lobby's influence in British politics meant that fiscal and financial policies remained tilted against Indian industrial interests. For example, the late imposition of a customs duty on British textile imports was counter-balanced by the levying of a countervailing excise duty on Indian cotton textiles. In eastern India, the jute mills that came up along the Hooghly River in the late nineteenth and early twentieth century were almost entirely European owned. By the late 1920s nearly half of the raw jute was consumed by these mills, but another half continued to be exported to Dundee in Scotland and other jute-manufacturing destinations in the West.

\subsection{The Era of Depression and War, the 1930s and 1940s}

With the onset of the 1930s depression the finely tuned structure of inter-regional interdependence across Asia quickly fell apart. Migrant Indians, Chinese and Javanese had formed on a conservative estimate at least $10 \%$ of the working population in Southeast Asia during the first three decades of the twentieth century. The world depression either reversed or arrested these demographic flows. In India, the depression witnessed a catastrophic price fall and a dramatic shrinkage in the availability of credit, which in turn spawned severe social tensions and political conflict. Having its origins in weakening demand for raw materials in the industrial West since 1926, the slump was accentuated in agrarian Asia as a result of policies adopted in Western Europe and the United States. The advanced industrialized countries of the West, including Britain, had responded to the crisis of the depression with policies of deflation, erection of protective tariff barriers, and huge cutbacks in foreign lending. In September 1931, the British pound sterling was taken off the gold standard, and the Indian rupee tied to it at a fixed exchange rate of 1 shilling and 6 pence. With the pound and the rupee effectively devalued against gold, and the rupee artificially 
pegged to the pound at a high exchange rate, a dramatic outflow of gold took place from India.

Between 1929 and 1931 the rising trend of the value of exports underwent a dramatic reversal in much of agrarian Asia including India, but not in silver-based China or Iran. The devaluation of China's silver-based currency helped to keep up the value of Chinese exports. The critical turning point for China came in 1933 once the United States went off the gold standard and launched a silver purchase program driving up the international price of silver. From 1933 massive outflows of silver from China began, the money supply contracted causing an acute deflationary downslide of prices. A neo-Smithian critique of Friedmanite monetarist economics as applied to China claims that although the silver stock declined the total money supply in China rose continuously from 1929 to 1935 . Both sides in the debate acknowledge that prices fell precipitously, whether owing to the quantity of money effect or the relative price effect. But the neo-Smithian intervention contains general claims about the strength of financial intermediation in China in the 1930s and stoutly denies that the US silver purchase policies set off a chain of bad economic events. On this view, China in this period had a free banking system on the commodity standard and that the Chinese banks in the period from 1929 to the currency reform of November 1935 issued real bills backed by reserves and government securities. But the historical evidence from agrarian China suggests that paper notes were freely being issued not just by banks but by landlords and grain-dealers, indeed, almost by anyone who had access to a printing press. Banking could not be freer and the bills could not be less real. Strong financial intermediation was not a characteristic of agrarian China at this time. Money was tight in the villages and it was extremely difficult to obtain even a small loan in cash. As in India, the buoyancy of output and intermediation in certain sectors of commerce and industry may have been at least in part based on the transfer of capital from the rural to the urban credit sector. The great outflow of silver from the hinterland to the coastal cities beginning in 1933 represented an unprecedented movement of financial capital out of agriculture, sparked by rising silver prices in the United States, a process not so dissimilar from the outflow of gold in India which constituted a massive disinvestment by the agrarian sector.

The political economy of late colonialism presented some marked departures from the classical patterns of the earlier era. The dislocations of World War I had provided effective, though not formal, protection to India's cotton textile industry. In 1922 London conceded fiscal autonomy to the colonial government of India. But it was the depression decade that fundamentally altered the metropolis-colony economic relationship. Lancashire dramatically lost out to Bombay and Ahmedabad whose cotton production far outstripped British imports. The British introduced a system of imperial preference in tariffs and trade through the Ottawa agreement of 1932. This kept Japanese goods from flooding the Indian market at a time when the Japanese were able to take over vast portions of the Southeast Asian and Middle Eastern markets beating the British not just in price but in the ability to cater to local taste.

The rupture of credit relations in agrarian India proved to be a lasting legacy of the depression decade. With the outbreak of war in Europe the winds of inflation started blowing in Asia and a dramatically new price conjuncture in global history began. 
Yet despite a dramatically different price conjuncture rural credit relations were not repaired. Partly this had to do with counter-productive political interference in the problem of rural debt. Also, prices of India's key cash crops did not rise as much as skyrocketing food prices. Three gigantic famines occurred in Asia during World War II between 1942 and 1945-in Bengal in India, Henan province in China, and Tonkin in Vietnam. These were all "man-made" famines in more senses than one, occurring in the context of no significant decline in aggregate food availability. The British late colonial state in India, the US-backed Guomindang regime in China, and the Japanese-supported Vichy government in Vietnam made disastrous state interventions in markets and showed a broadly similar apathy towards organizing famine relief. The reconfiguration of relations between the state and the market during the war and its aftermath influenced the transformations of the post-colonial era (Sen 1981; Bose 1990).

The inflationary pressure in India was triggered by a huge expansion in public expenditure. Colonial India had to pay for war expenditure here and now by printing rupees while sterling credits built up in the Bank of England. The money supply in India rose from about Rs. 3 billion in 1939 to Rs. 22 billion in 1945. Galloping inflation caused immense hardship to the rural poor who suffered grievously in the Bengal famine in which between 3.5 and 3.8 million people died. At the same time, the war economy reversed the longstanding debt relationship between metropolis and colony, as well as the nature of the links between the colonial state and the economy. By war's end Britain owed a debt of L 1.3 billion to the colonial government of India. The colonial state had intruded into the food market to provision troops and industrial workers, procuring grains from rural areas and selling through ration shops in towns and cities. The terrible famine of 1943 shredded what little remained of the legitimacy of the British raj in India (Baily and Harper 2005).

\subsection{The Era of State-Led National Development, 1940s to $1990 \mathrm{~s}$}

This is the one period marking the heyday of the nation-state characterized by the disruption of older forms of intra-Asian connections and the pursuit of alternative approaches to economic development. The spectacular post-war recovery of Japan between the 1950s and 1970s provided a model for the export-led economic development paradigms of the so-called Asian tigers-South Korea, Taiwan, Singapore and Hong Kong. Yet the example of these island-nations—big, medium and small—was not emulated by the large continental nation-states. The more populous countries of Asia-India and China in particular-followed variants of import-substituting industrialization with different degrees of success. Post-1947 India staved off the specter of colonial-era famines, but remained beset by chronic malnutrition and hunger. Post1949 China scored well in normal years in the field of basic health and education, but could not prevent the largest famine of the twentieth century during the "great 
leap forward" in 1959-61. Both managed to build a heavy industrial base, but growth rates remained sluggish.

It is important to note that the concept of national development predated that of colonial development in India. The Indian National Congress headed by Subhas Chandra Bose had set up a National Planning Committee with Jawaharlal Nehru as chairman to draw up blueprints for the economic and social reconstruction of India two years before the passage of the British Colonial Development and Welfare Act of 1940. Rabindranath Tagore, despite being skeptical of the modern nation-state, supported Bose's modernist vision of economic reconstruction. This vision differed from Mohandas Gandhi's predilection for self-governing and self-sufficient village communities.

Yet a scholarly obsession with the contrast between Gandhi's localism and Nehru's centralism misses out a whole range of thinkers and planners in between who proposed innovative ways of crafting the relationship between nation and state and a balanced view of the role of the state in development. There were many self-avowed socialists who did not subscribe to the Nehruvian project of centralization and were more amenable to ideas of regional autonomy and an equitable sharing of power among different religious communities as the basis for development. The capture of power at the apex of a centralized postcolonial state also led to a forgetting of the idioms of national development emphasizing the removal of poverty, illiteracy and disease in favor of an instrumental approach (Bose 1997).

This was not simply a case of Nehruvian modernism triumphing over Gandhian traditionalism. Modernist socialists criticized the Nehruvian state for eagerly inheriting the colonial mantle. The scientist Meghnad Saha, a key figure in the National Planning Committee during 1938-1940, lamented that the Bombay Plan of 1944 had been hatched by "a syndicate of capitalists," that the Department of Planning and Development established later that year was the handiwork of "foreign bureaucrats," and that in the case of the Bengal Government Plan of 1945 "the Civil Service provided the philosophy and the direction." (Chatterjee 1986, pp. 431, 445). The official version of development had not only arisen after but was now betraying the popular, national efforts in that direction.

Postcolonial India relied more on the colonial Planning and Development Department set up in 1944 than the work of the National Planning Committee during 1938-1940. From the mid-1950s Indian planners led by P.C. Mahalanobis opted for the path of capital-goods led import-substituting industrialization. This was a departure from the more ubiquitous "textiles first" model which was the choice of neighboring Pakistan. It was also quite at variance with the "export-led" strategies pursued by Southeast Asian countries in imitation of Japan. It is clear that the export pessimism in India around 1960 was completely misplaced and may have been a missed opportunity to accelerate economic growth. But the bigger failure related to the utter neglect of primary education and primary health care. In the first two decades after independence India was an "emergent state" to the extent that it successfully improved the savings rate, set up a heavy industrial base centering on iron and steel and chemicals, and from the 1960s broke out from the agricultural stagnation of the first half of the twentieth century 
In the late 1960s and early 1970s the lost idioms of national development were partially but not wholly rediscovered in the "populist" political and economic program of Indira Gandhi with its emphasis on poverty eradication and rural employment. This rediscovery was based on a realization that the Nehruvian consensus had not cared to address the means-using needs of the poor. Yet even Indira Gandhi's populism left a gap between prospectus and performance. In the late 1980s Sen (1989, p. 374) offered a lucid assessment of India's development experience in the first four decades since 1947 by drawing a distinction between what is instrumental and what is intrinsic: "The importance of savings and investment is instrumental rather than intrinsic," he wrote, "and any enhancement of instrumental variables may be washed out, in the tally of final accounting, by a deterioration of the impact of that instrumental variable on things that are intrinsically valuable." Post-1947 India did not have post-1949 China's direct and massive public action to improve living conditions. This accounted for the fifteen-year difference in average life expectancy in the two countries by the late 1980s. If India had China's lower mortality rates, "there would have been 3.8 million fewer deaths in India around the middle 1980s." As Sen (1989, p. 384) puts it, "every eight years or so more people in addition die[d] in India-in comparison with Chinese mortality rates - than the total number that died in the gigantic Chinese famine."

\subsection{India in the Era of "the Rise of Asia"}

In 2016 India completed twenty-five years of economic reforms initiated in 1991. P.V. Narasimha Rao, prime minister from 1991 to 1996 instructed his finance minister Manmohan Singh to dismantle what had come to be called the permits, licenses and subsidy raj. In mid-1991 India faced an acute balance-of-payments crisis, making it necessary to seek an IMF loan to tide over it. However, the Indian state made a virtue out of necessity by removing the many barriers to the entry, expansion and diversification of firms by proclaiming a new industrial policy. The stifling practice of licensing the use of industrial capacity was virtually abolished. The bureaucratic logjams on the road to economic development were gradually removed. Jean Dreze and Amartya Sen noted that these economic reforms addressed only the first part of a two-pronged problem facing Indian economic development. The reformers pulled back from over-intervention by the state in certain sectors but did not redress state negligence of social sectors, especially, health and education.

Any assessment of emergent states needs to place in context and explain the phenomenon widely described as the rise of Asia since the opening up of China to the global economy since 1979 and the economic reforms in India since 1991. In 1979 the size of the economies of China and India was roughly the same. After nearly four decades of rapid growth in both countries China's economy is now five times the size of India's economy. Even though India accelerated from the 3-4\% "Hindu" rate of growth of the 1947-1980 period, China grew much faster as it quickly became the manufacturing hub of the world exporting to overseas markets. The emphasis 
on health care and education in the Maoist era had also enhanced the quality of labor that served as the springboard for rapid economic development in the post1979 era. Between 1900-1901 and 1946-1947 the Indian economy had stagnated recording growth rates of $0.90 \%$ total and $0.10 \%$ per capita. The corresponding figures in 1950-51 to 1960-61 were 3.70\% total and 1.80\% per capita, from 1960-61 to $1970-713.40 \%$ total and $1.20 \%$ per capita, and from 1970-71 to 1980-81 also $3.40 \%$ total and $1.20 \%$ per capita. From the early 1980 s there was a spurt in growth, well before the launch of the celebrated economic reforms of 1991. From 1980-81 to $1990-91$ the Indian GDP grew at 5.20\% total and 3.00\% per capita, from 1990-91 to $2000-01$ at $5.90 \%$ total and $3.90 \%$ per capita, and from $2000-01$ to $2010-11$ at $7.60 \%$ total and $6.00 \%$ per capita. The growth rate peaked at $9.00 \%$ early in the current decade before falling back to under $6.00 \%$ in the current year.

It is important to ask what the dramatic acceleration of economic growth rates in emergent Asia has meant for the global balance of power and what impact it has had internally on the pressing problems of poverty and inequality. Also, the rise of Asia is not a linear story, but one interrupted by downturns, such as, the Asian financial crisis of 1997-98. India was better able to ride out that crisis than several countries in Southeast Asia, especially, Thailand, Indonesia and the Philippines. If the forces of contemporary globalization have a dark under-belly, so do the flows of labor migration that constitute today's Asian inter-regional arena. Yet there is no gainsaying the fact that with China as creditor to the United States and Asia as a whole powering ahead in manufacturing and services, the relations between Asia and the West are much different today from what they were two centuries ago.

Where does India stand in relation to the rest of Asia beyond the widening gap in the size of the economies of China and India in the last four decades? To be sure, India has emerged at a pace second only to China as Asia recovered in the early twenty-first century the global position it had lost in the late eighteenth. Dynamic economic growth infused a new sense of confidence. India was able to cope with the global financial crisis of 2008-9 in a more efficient manner than most countries of the world. Yet India's performance in the areas of basic education and health care for the poor has left much to be desired in comparison with other countries of Asia, excepting Pakistan. India ran the risk, as Amartya Sen put it, of becoming half-California and half sub-Saharan Africa. The rich in the major urban centers indulge in conspicuous consumption while the tribal peoples in India's rural and forest heartland continue to suffer acute deprivation. A very large number of districts in Bihar, Jharkhand, West Bengal, Orissa, Chhattisgarh and Andhra Pradesh have witnessed resistance by peasants and forest peoples to protect their rights to land against incursions by large capitalists.

The current government headed by Narendra Modi came to power promising development and announced a "make in India" campaign with much fanfare in 2014. However, as China has moved up the manufacturing chain, countries like Vietnam, Cambodia and Bangladesh have taken its place as manufacturing centers with relatively low labor costs. India may have already missed that bus and is increasingly reliant on the buoyance of the services sector as the agrarian sector continues to languish. The current government's attempt to pass a land acquisition law that would 
have made it easier to alienate peasant and tribal land was successfully resisted by the opposition.

The government's rhetoric about development has not been matched by actual accomplishment. The politics of religious polarization and caste conflict also do not bode well for the development agenda. On November 8, 2016, Narendra Modi suddenly announced the immediate demonetization of Rs. 500 and Rs. 1000 currency notes amounting to $86 \%$ of the circulating currency. This measure undermined the economy of trust, causing immense distress to elderly citizens and poor workers in the vast informal sector of the economy. It also contributed to the slowdown in the rate of economic growth. Yet it is not this deceleration of growth but distributional issues that pose the greater challenge to emergent states of Asia, including India.

An analytical survey of the economic history of India in broader Asian and global contexts yields one powerful insight or conclusion. Asia has prospered not through economic autarky, but by mustering the political and cultural resources to set the terms of global engagement, something that was effectively denied in the colonial era throughout all of Asia excepting Japan. In this process of denial colonized India suffered most grievously. It is by engaging with the global economy and recovering its own agency that much of Asia is being able not just to ride the upswings of the global economy but also to reduce vulnerabilities to its more volatile downturns, such as, the one that gripped the world since 2008-09. As the United States and parts of Europe turn inward, India and the rest of Asia have an opportunity to enhance intraAsian trade and investment while keeping the lines of economic exchange open with the rest of the world. If India and the rest of Asia can address the problems of inequity alongside achieving rapid growth, what many predict will be an Asian century can turn out to be a truly prosperous era in the history of the continent.

\section{References}

Ali, T. O. (2018). A local history of global capital. Princeton: Princeton University Press.

Baker, C. J. (1981). Economic reorganization and the slump in South and Southeast Asia. Comparative Studies in Society and History, 23(3), 325-349.

Bayly, C. A. (1988). Indian society and the making of the British Empire. Cambridge: Cambridge University Press.

Bayly, C. A., \& Harper, T. N. (2005). Forgotten armies. Cambridge, MA: Harvard University Press. Bose, S. (1990). Starvation amidst plenty: The making of famine in Bengal, Honan and Tonkin, 1942-45. Modern Asian Studies, 24(4), 699-727.

Bose, S. (1993). Peasant labor and colonial capital. Cambridge: Cambridge University Press.

Bose, S. (1997). Idioms and instruments of colonial and national development. In F. Cooper R. Packard (Eds.), International development and the social sciences. Berkeley, CA: University of California Press.

Bose, S. (2008). Pondering poverty, fighting famines: towards a new history of economic ideas. In K. Basu R. Kanbur (Eds.), Arguments for a better world: Essays in honor of Amartya Sen (Vol. II). Oxford: Oxford University Press.

Chatterjee, S. (Ed.). (1986). Collected works of Meghnad Saha (Vol. 2). Calcutta: Saha Institute of Nuclear Physics; Bombay: Orient Longman, 1987. 
Chaudhuri, K. N. (1990). Asia before Europe: Economy and civilization of the Indian Ocean from the rise of Islam to 1750. Cambridge: Cambridge University Pres.

Davis, M. (2000). Late Victorian Holocausts: El Niño Famines and the making of the third world. London: Verso.

Fay, P. (1997). The Opium War, 1840-1842. Chapel Hill: University of California Press.

Lowe, L. (2015). The intimacies of four continents. Durham, NC: Duke University Press.

Nadri, G. A. (2016). The political economy of Indigo in India, 1580-1930: A global perspective. Leiden: Brill.

Parthasarathi, P. (2011). Why Europe grew rich and Asia did not: Global economic divergence, 1600-1850. Cambridge: Cambridge University Press.

Pomeranz, K. (2000). The great divergence; China, Europe and the making of the Modern World Economy. Princeton, NJ: Princeton University Press.

Sen, A. (1981). Poverty and famines. Oxford: Clarendon Press.

Sen, A. (1989). Indian development: Lessons and non-lessons. Daedalus, 118(4), 369-392.

Sugihara, K. (2013). Labor-intensive industrialization in global history: An interpretation of East Asian experiences. In G. Austin \& K. Sugihara (Eds.), Labor-intensive industrialization in global history. New York: Routledge.

Trocki, C. (1999). Opium, empire and the global political economy. London: Routledge.

Open Access This chapter is licensed under the terms of the Creative Commons AttributionNonCommercial-NoDerivatives 4.0 International License (http://creativecommons.org/licenses/bync-nd/4.0/), which permits any noncommercial use, sharing, distribution and reproduction in any medium or format, as long as you give appropriate credit to the original author(s) and the source, provide a link to the Creative Commons license and indicate if you modified the licensed material. You do not have permission under this license to share adapted material derived from this chapter or parts of it.

The images or other third party material in this chapter are included in the chapter's Creative Commons license, unless indicated otherwise in a credit line to the material. If material is not included in the chapter's Creative Commons license and your intended use is not permitted by statutory regulation or exceeds the permitted use, you will need to obtain permission directly from the copyright holder.

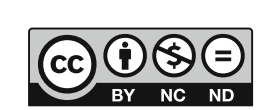




\title{
Chapter 7 \\ Middle-Income Trap in Emerging States
}

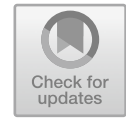

\author{
Tetsushi Sonobe
}

\subsection{Introduction}

The middle-income trap refers to a middle-income country's failure to become a highincome country in a timely manner. Many examples are found in Latin America and Middle East. In light of the recent growth slowdown of the Chinese economy, one cannot deny the possibility that even hitherto fast-growing Asian emerging states might fall into the trap. It is no wonder that much has been written about the trap since the pioneering work by Gill and Kharas (2007).

According to Kharas and Kholi (2011, p. 281), trapped countries are "unable to compete with either low-wage economies or highly skilled advanced economies." The economist typically points to the critical need for industrial upgrading, which in turn requires increased innovation capacity and an education system tuned to an innovation-led economy (e.g., Glawe and Wagner 2017; Agénor 2017), while the political scientist rather stresses the difficulty of meeting the need. For example, Tsunekawa (Chap. 2 of this volume) argues that technological upgrading requires the coordination of interests between management and labor. Kanchoochat (Chap. 3 of Volume 3) argues that economic growth inevitably creates winners and losers, which is a source of conflicts, and that unless conflict is managed, growth cannot continue. Shiraishi (Chap. 1 of this volume) argues that Asian emerging states will not be able to keep their economies growing without working on nation building. Hill et al. (2012, p. 1704) argue that innovation as "a painful process of creative destruction" in which old firms and industries are replaced by new ones may be blocked by the "political power of old firms."

This chapter takes part in the discussion on the politics of economic growth. It focuses on middle-income economies, for which rapid economic growth for an

\footnotetext{
T. Sonobe $(\varangle)$

Graduate School of Policy Studies, National Graduate Institute for Policy Studies (GRIPS),

Minato-Ku, Tokyo, Japan

e-mail: sonobete@grips.ac.jp

(C) The Author(s) 2019
}

T. Shiraishi and T. Sonobe (eds.), Emerging States and Economies, Emerging-Economy

State and International Policy Studies, https://doi.org/10.1007/978-981-13-2634-9_7 
extended period is needed to avoid the middle-income trap or to realize their dream of entering the ranks of high-income countries. We begin with the question of whether the trap is a real problem for emerging states. Tsunekawa (Chap. 2) identifies 29 countries as emerging states that have a set of defining characteristics. We find that the majority of these emerging states, including several Asian emerging states, are trapped according to frequently used definitions of the trap. Thus, it is really difficult for a middle-income country to become a high-income country in a timely manner.

To understand why it is so difficult to avoid the trap, and to explore a way to make it easier, this chapter develop a framework that accommodates both economic and political views of the economic growth of emerging states. In economics, a common approach to growth is to divide the economy into households or consumers, firms, and the government, and another approach is to classify growth drivers into the input accumulation type and the productivity growth type. These approaches, however, seem to make it difficult to think of political coordination for managing conflicts that economic growth creates, coping with vested interests, and taking care of those who cannot keep pace with changing environments due to economic growth.

As a first step, this chapter tries an uncommon approach that highlights the roles of households, industries or industrialists seeking innovations and overseas operation, vested interests and protectionists, politicians and the government, and the rest of the world in determining economic growth and equity. This trial is motivated by a hope that concrete images will help us form ideas about relevant interactions of economic and political forces.

The household sector contributes to economic growth by providing education for children or accumulating human resources. In recent years, the quality of education rather than the quantity has attracted attention of researchers who empirically analyze the relationship between education and economic growth. Education is also believed to be closely associated with economic equity. How are the quantity and quality of education related with economic growth and equity? Educational reforms are often postponed despite the wide spread belief that education holds the key to long-term growth of the economy and also to successful careers of individuals. We attempt to address these issues.

It is well known that most innovations take place in industrial clusters, where producers of the same goods and intermediate inputs are concentrated, and other economic agglomerations such as large cities and industrial zones. Agglomerations expand faster if they have good connectivity with the rest of the world as it facilitates foreign trade and investment. Innovations and external trade and investment are said to boost industrial development, which in turn contributes to economic growth. This chapter points out that industrial development, unlike educational development, does not contribute to equity and rather aggravates inequality because innovation creates winners and losers and agglomeration creates center and periphery. It discusses the key enabler for innovations and industrial upgrading in the middle-income stage. It then considers how to save innovations and industrial upgrading from the obstruction of vested interests and protectionists.

The emerging states today include both giant countries, such as China and India, and much smaller countries, such as Southeast Asian countries. This chapter applies 
the findings and arguments about educational and industrial developments to the discussion of the advantages and disadvantages as well as different behaviors between large and small emerging states.

\subsection{How Difficult Is It to Avoid the Middle-Income Trap?}

The existing studies propose some detailed definitions of the trap that are used to determine which countries are caught in the trap. This section applies such definitions to the 29 emerging states identified in Chap. 2 to see how common the trap is.

Glawe and Wagner (2017) and Im and Rosenblatt (2013) point out that many studies have defined the middle-income trap as staying for more than 50 years in a middle-income range, which is in turn defined as two thresholds as the percentage of a reference country's income level (usually the US level). Table 7.1 reports the results of applying two slightly different definitions of the middle-income range on a relative basis to a sample of 135 countries. In Panel $A$ of this table, the middle-income range in a given year is defined as $6-45 \%$ of the US level of GDP per capita. ${ }^{1}$ In Panel B, the range is defined as $10-50 \%$ of the US level. Many studies use income ranges similar to these ranges.

While the two panels are based on the data from the same sample countries, they exhibit considerably different outcomes. In Panel $A, 15$ countries were low-income countries and 65 were middle-income countries in 1960, while the corresponding numbers in Panel $B$ were 35 and 46. This is because there were 20 countries in a narrow income range between 6 and $10 \%$ of the US level. By contrast, the number of high income countries is stable. There was only one country in the $45-50 \%$ range. Whether a country was a low- or middle-income country depends on the definition of the lower boundary of the middle-income range. There is no theory about where to set this boundary. As a result, the number of countries trapped in the middle-income status varies considerably. In Panel A, 38 remained in this range (that is, $\mathbf{M} \rightarrow \mathbf{M}$ ) 50 years later and are regarded as trapped under the tentative definition. In Panel B, only 27 countries are regarded as trapped.

The results of applying these definitions to the 29 emerging states are presented in Table 7.2. The first three columns adopt the 6-45\% range as in Panel $A$ of Table 7.1, while the next three columns adopt the $10-50 \%$ range as in Panel $B$. As of 2010, China, Pakistan, and Thailand may or may not be in the trap, depending on whether they had crossed an arbitrary threshold 50 years ago but not on how they have been faring in recent years. This kind of definition is not satisfactory. Currently, however, no alternative is available. Moreover, it is safe to say that many middleincome countries seem to be in the trap and that not only emerging states in Latin America and the Middle East but also some Asian emerging states are suspected

\footnotetext{
${ }^{1}$ Real GDP per capita are obtained by dividing the expenditure-side real GDP at chained purchasing power parities (PPPs) in million 2011 US\$ over population. Both data are taken from the latest version (PWT 9.0) of the Penn World Table (Feenstra et al. 2015).
} 
Table 7.1 Number of countries by income range

\begin{tabular}{|c|c|c|c|c|}
\hline \multirow[t]{2}{*}{ Panel $A$} & \multirow[t]{2}{*}{ Total } & Low & Middle & High \\
\hline & & Less than $6 \%$ & $\begin{array}{l}\text { Between } 6 \text { and } \\
45 \%\end{array}$ & More than $45 \%$ \\
\hline 1960 & 96 & 15 & 65 & 16 \\
\hline 2010 & 135 & 30 & 71 & 34 \\
\hline 2014 & 135 & 26 & 70 & 39 \\
\hline \multirow{3}{*}{\multicolumn{2}{|c|}{$\begin{array}{l}\text { Number of countries that was in the } \\
\text { indicated ranges in } 1960 \text { and } 2010\end{array}$}} & $\mathrm{~L} \rightarrow \mathrm{L} 9$ & $\mathrm{M} \rightarrow \mathrm{M} 38$ & $\mathrm{H} \rightarrow \mathrm{H} 16$ \\
\hline & & $\mathrm{L} \rightarrow \mathrm{M} 6$ & $\mathrm{M} \rightarrow \mathrm{H} 11$ & $\mathrm{H} \rightarrow \mathrm{M} 0$ \\
\hline & & $\mathrm{L} \rightarrow \mathrm{H} 0$ & $\mathrm{M} \rightarrow \mathrm{L} 16$ & $\mathrm{H} \rightarrow \mathrm{L} 0$ \\
\hline Panel $B$ & & Less than $10 \%$ & $\begin{array}{l}\text { Between } 10 \text { and } \\
50 \%\end{array}$ & More than $50 \%$ \\
\hline 1960 & 96 & 35 & 46 & 15 \\
\hline 2010 & 135 & 42 & 60 & 33 \\
\hline 2014 & 135 & 40 & 61 & 34 \\
\hline \multirow{3}{*}{\multicolumn{2}{|c|}{$\begin{array}{l}\text { Number of countries that was in the } \\
\text { indicated ranges in } 1960 \text { and } 2010\end{array}$}} & $\mathrm{~L} \rightarrow \mathrm{L} 23$ & $\mathrm{M} \rightarrow \mathrm{M} 27$ & $\mathrm{H} \rightarrow \mathrm{H} 15$ \\
\hline & & $\mathrm{L} \rightarrow \mathrm{M} 11$ & $\mathrm{M} \rightarrow \mathrm{H} 11$ & $\mathrm{H} \rightarrow \mathrm{M} 0$ \\
\hline & & $\mathrm{L} \rightarrow \mathrm{H} 1$ & $\mathrm{M} \rightarrow \mathrm{L} 8$ & $\mathrm{H} \rightarrow \mathrm{L} 0$ \\
\hline
\end{tabular}

Notes

The 135 sample countries were selected by two criteria. One is that real GDP data are available from the Penn World Table 9.0 (Feenstra et al. 2015). The other is that the countries appear in Tables 1A and 1B of Felipe et al. (2012) so that their income classification can be compared with ours. GDP per capita in 1960 is available only for 96 out of 135 countries

of being trapped. ${ }^{2}$ Thus, it is very difficult for middle-income countries to become high-income countries.

\subsection{A Conceptual Framework}

The economist decomposes economic growth into input accumulation and productivity gains. The political scientist rather thinks of conflicts and vested interests created by economic growth, and the need for taking care of those who cannot keep pace with rapidly changing society. A possible conceptual framework accommodating both views is illustrated in Fig. 7.1. With a view to unleashing our imagination, the framework classifies actors relevant to economic growth into four groups: households, industries, those with vested interests and protectionists in the three boxes in the center of the diagram, and political leaders and bureaucrats in the left box.

\footnotetext{
${ }^{2}$ Using a different approach to income classification, Felipe et al. (2012) reach the same conclusion.
} 
Table 7.2 Which emerging states are trapped

\begin{tabular}{|c|c|c|c|c|c|c|}
\hline & \multicolumn{3}{|l|}{ (1) } & \multicolumn{3}{|l|}{ (2) } \\
\hline & \multicolumn{3}{|c|}{ Middle income $=6-45 \%$} & \multicolumn{3}{|c|}{ Middle income $=10-50 \%$} \\
\hline & 1960 & 2014 & Trapped? & 1960 & 2014 & Trapped? \\
\hline Argentina & M & M & Yes & M & M & Yes \\
\hline Algeria & M & M & Yes & M & M & Yes \\
\hline Brazil & M & M & Yes & M & M & Yes \\
\hline Chile & M & M & Yes & M & M & Yes \\
\hline China & M & M & Yes & $\mathrm{L}$ & M & No \\
\hline Columbia & M & M & Yes & M & M & Yes \\
\hline Egypt & $\mathrm{L}$ & M & No & $\mathrm{L}$ & M & No \\
\hline India & $\mathrm{L}$ & M & No & $\mathrm{L}$ & $\mathrm{L}$ & No \\
\hline Indonesia & $\mathrm{L}$ & M & No & $\mathrm{L}$ & $\mathrm{L}$ & No \\
\hline Iran & M & M & Yes & M & M & Yes \\
\hline Iraq & - & M & $?$ & - & $\mathrm{M}$ & $?$ \\
\hline Israel & $\mathrm{H}$ & $\mathrm{H}$ & No & M & $\mathrm{H}$ & No \\
\hline Kazakhstan & - & M & $?$ & - & M & $?$ \\
\hline Korea & M & $\mathrm{H}$ & No & L & $\mathrm{H}$ & No \\
\hline Malaysia & $\mathrm{M}$ & M & Yes & $\mathrm{M}$ & $\mathrm{M}$ & Yes \\
\hline Mexico & M & M & Yes & M & $M$ & Yes \\
\hline Nigeria & M & M & Yes & M & M & Yes \\
\hline Pakistan & M & M & Yes & $\mathrm{L}$ & $\mathrm{L}$ & No \\
\hline Peru & $\mathrm{M}$ & M & Yes & $M$ & M & Yes \\
\hline Philippines & $\mathrm{M}$ & M & Yes & $\mathrm{M}$ & $\mathrm{M}$ & Yes \\
\hline Poland & - & $\mathrm{H}$ & $?$ & - & M & $?$ \\
\hline Russia & - & $\mathrm{H}$ & $?$ & - & M & $?$ \\
\hline $\begin{array}{l}\text { Saudi } \\
\text { Arabia }\end{array}$ & - & $\mathrm{H}$ & $?$ & - & $\mathrm{H}$ & $?$ \\
\hline Singapore & $\mathrm{M}$ & $\mathrm{H}$ & No & $M$ & $\mathrm{H}$ & No \\
\hline $\begin{array}{l}\text { South } \\
\text { Africa }\end{array}$ & M & M & Yes & M & M & Yes \\
\hline Taiwan & M & $\mathrm{H}$ & No & M & $\mathrm{H}$ & No \\
\hline Thailand & M & M & Yes & $\mathrm{L}$ & $M$ & No \\
\hline Turkey & M & M & Yes & M & $\mathrm{M}$ & Yes \\
\hline Venezuela & M & M & Yes & $\mathrm{M}$ & $\mathrm{M}$ & Yes \\
\hline
\end{tabular}

\section{Notes}

The countries are arranged in alphabetical order. The symbols - and ? indicate that data are not available and that whether the country is trapped cannot be determined, respectively 


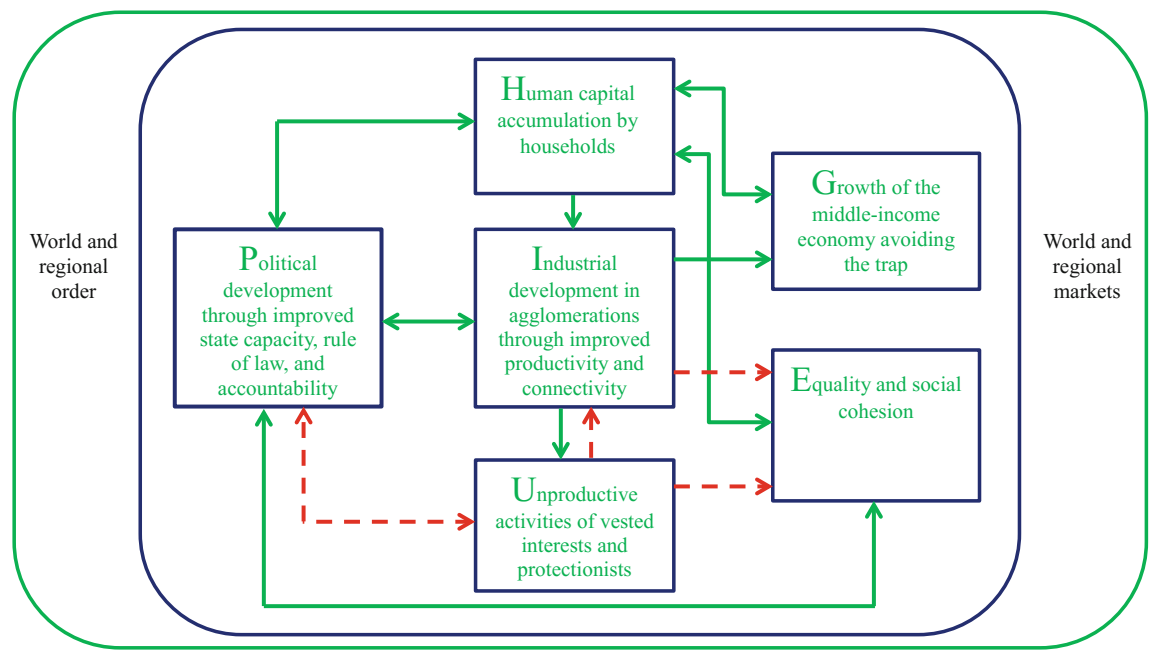

Fig. 7.1 Conceptual framework

Households contribute to economic growth primarily through human capital accumulation, most of which is accounted for by investment in the education of children. Educated individuals work in industries (or more generally, productive sectors including the primary and tertiary sectors) and the government as politicians or bureaucrats. Human capital accumulation contributes to economic growth through industrial development, which is indicated in the figure by the green solid arrows running from Box H to Box I and from Box I to Box G. Households are also owners of financial and physical assets. Their savings contribute to industrial development and economic growth, but this route is not as critically important in the globalized world as productive activities could obtain finance from foreign sources if the economy is open to international finance.

In Fig. 7.1, Box $\mathrm{H}$ and Box $\mathrm{G}$ are connected with a left-pointing arrow, which is based on the assumptions that economic growth enhances human capital accumulation probably by relaxing the financial constraint on education, and that human capital accumulation does not directly enhance economic growth. The latter assumption may be justified because industry refers here to all directly productive activities.

By contrast, directly unproductive activities, represented by Box U, include rent seeking activities and litigation activities intended to deter new entry of potential rivals. Such activities would be driven by profit motivation and generate incomes, but they are not socially productive. Since they would hinder industrial development and increase income inequality, red dotted arrows (which mean negative effects) extend from Box U to Boxes I and E. Moreover, vested interests, monopolists, protectionists might turn into cronies, capture the state, and hinder the rule of law and accountability on one hand, and if state capacity is increased, on the other hand, it will become possible to implement a competition law, to control rent seeking activities, and to 
fight against corruption. Thus, the red dotted arrow between Boxes $\mathrm{U}$ and $\mathrm{P}$ is pointing in both directions.

The government raises tax revenues and receives human resources from the household and industrial sectors. It provides households and industries with a variety of public services and infrastructure including public education, healthcare, necessary regulations, measures correcting market failures, and so on. Hence, the arrow between Boxes $\mathrm{P}$ and $\mathrm{I}$ and that between Boxes $\mathrm{P}$ and $\mathrm{H}$ are pointing in both directions. ${ }^{3}$ Since social welfare programs will increase economic equality, and since social cohesion will help political development, Boxes $\mathrm{P}$ and $\mathrm{E}$ are connected with a green solid arrow pointing in both directions.

Figure 7.1 provides multiple explanations for the difficulty in avoiding the middleincome trap. For example, industrial upgrading may be difficult to take place because of inadequate human capital, inadequate industrial policy, or interference from old firms. Even if industrial development was successful in the past, it might lead to deterioration in equality and social cohesion, which might in turn undermine political stability. Instability may reduce state capacity to collect taxes and to implement policies effectively, thereby hindering human capital accumulation and industrial development. A considerable compilation of empirical studies will be needed to determine which explanation is more relevant. Figure 7.1 can be used to develop hypotheses for such investigation.

\subsection{Education}

\subsubsection{Educational Catch-up and Economic Catch-up}

Few readers would hesitate to agree that human capital accumulation is positively related to long-run economic growth. If we take a closer look, the relationship between education and growth is quite complicated. The question, for example, arises as to how concurrently the two development processes occur? Using the data compiled by Godo (2010) and borrowing the idea of Godo and Hayami (2002), the first panel of Fig. 7.2 shows the processes of economic catch-up and educational catch-up in Japan from 1890 to 2000 . Here, education attainment is measured by the average number of years of schooling in adult population, and economic development is measured by GDP per capita. The extent of catch-up is measured by the Japanese level as percentage of the US level. The other panels of Fig. 7.2 use the Barro-Lee educational attainment data to show the same ratios in 12 other East Asian countries over a shorter period from 1965 to 2010.

In Japan, educational catch-up accelerated as early as the $1890 \mathrm{~s}$, but economic catch-up took place much later. A possible interpretation is that the early spurt in educational development was an investment with a very long gestation period. Korea

\footnotetext{
${ }^{3}$ In the same vein, Besley and Persson (2010) emphasize the roles of state capacity to raise taxes (fiscal capacity) and support markets (legal capacity) in state building and economic development.
} 
followed and China is following similar processes, while Taiwan did so to a lesser degree. Although not shown here, many Latin American and Eastern European countries share similar patterns. In Singapore and Hong Kong, however, educational catchup and economic catch-up took place concurrently; the same happened in Portugal. The question arises as to why the length of the investment gestation period varies so much.

There are at least three possible answers. First, the quality of education may be what really matters to economic growth, but it is missing in the figure. The years of schooling measure the quantity of education, not the quality. It may well be that when the quality of education was low, a gap widened between educational and economic catch-up levels, and the gap narrowed as the quality improved gradually. One may
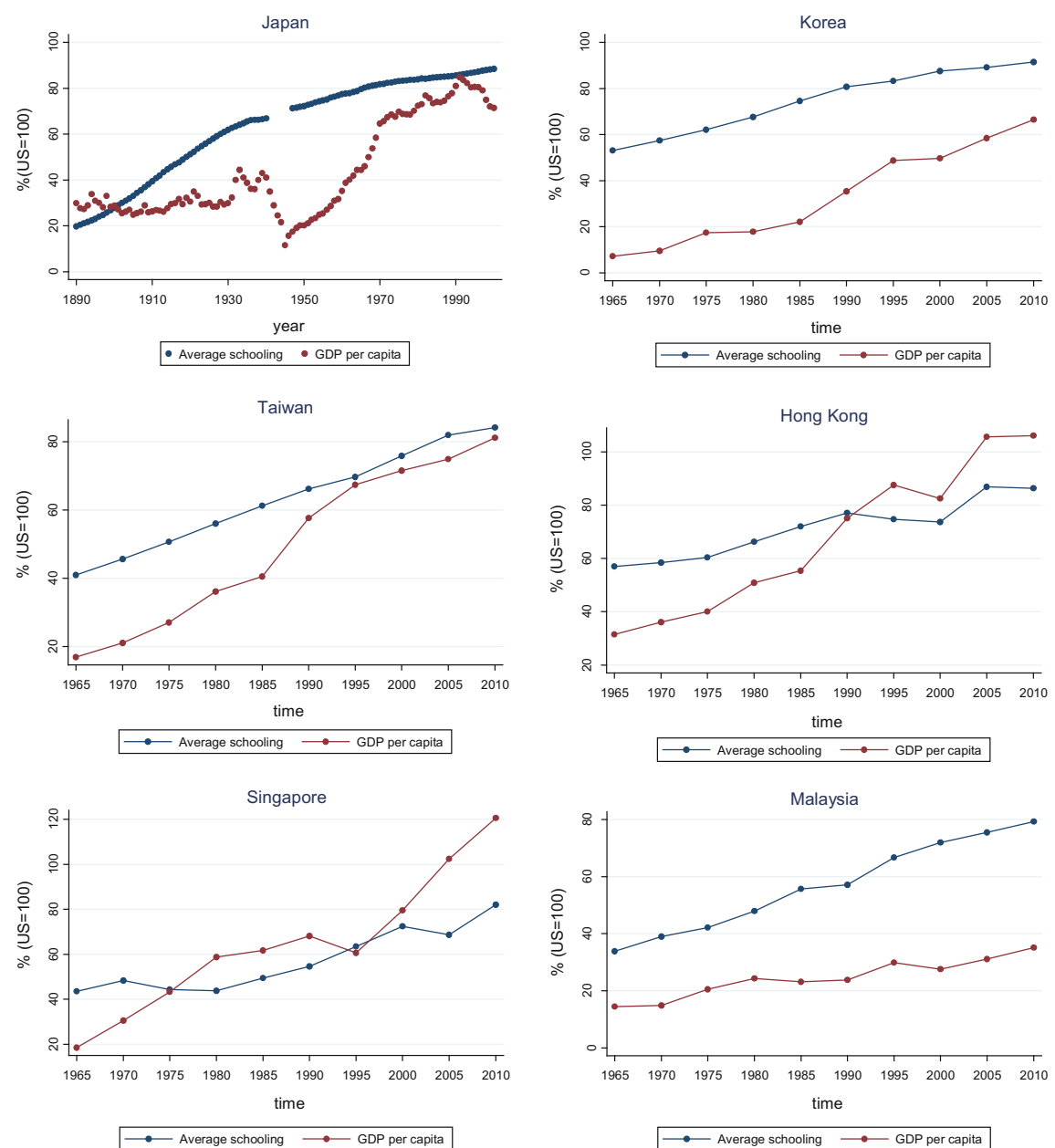

Fig. 7.2 Educational catch-up and economic catch-up in East Asia 


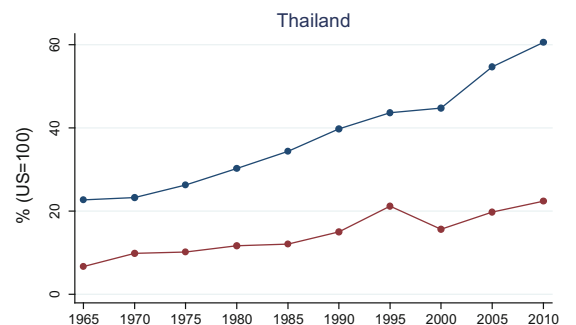

time

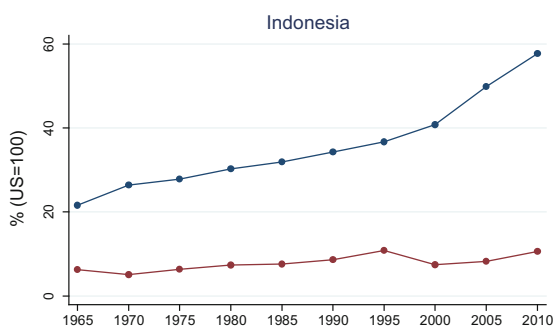

time
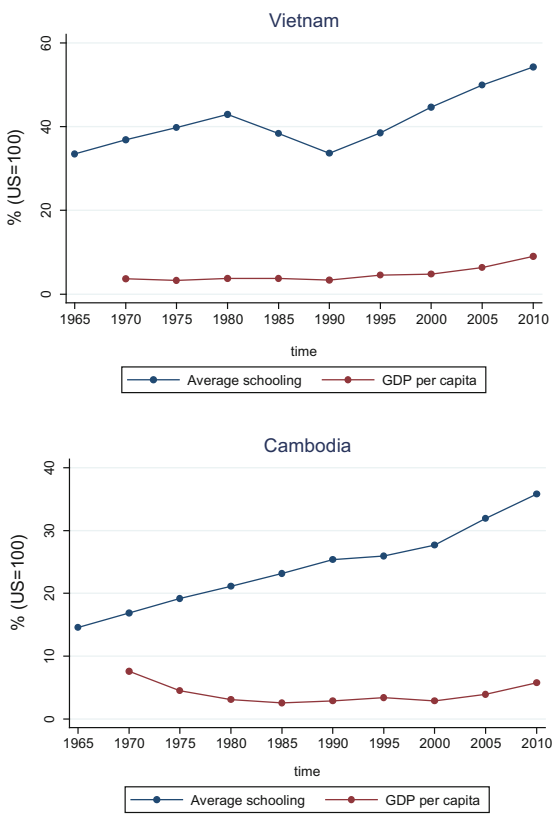

Fig. 7.2 (continued)
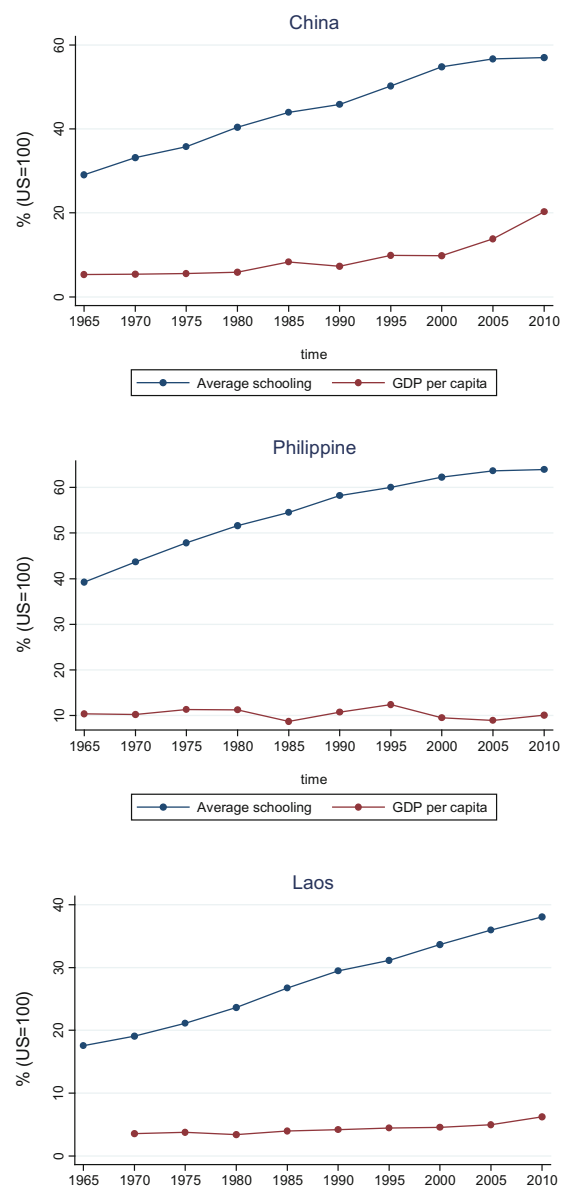

time

$\longrightarrow$ Average schooling $\longrightarrow$ GDP per capita 
wonder, however, why people went to school for many years if education was so low-quality that it contributed little to income growth. Similarly one may wonder why the government built many schools that would contribute only little to income growth. These are interesting, open questions. Probably, what people cared was their personal income, not GDP per capita. They might expect that academic credentials would serve as a signal in labor markets and get them high-paid jobs. The government might expect education to help to create a sense of national identity.

Second, international port-city states like Singapore and Hong Kong would have thriving service sectors like international commerce and financial services. They could offer jobs compatible with high education even in early stages of economic development. By contrast, larger countries with vast hinterland tended to start their economic development as agrarian economies, where the effect of education on productivity would be more limited. Taiwan is an island and its population and territory are not large, but it is not like a port-city state. Instead, it achieved rapid economic growth led by the development of labor-intensive, light-manufacturing industries in the 1970s and 1980s. Micro and small enterprises mushroomed to form industrial clusters in and around major cities. Taiwan was called a "boss island" because there were many business owners relative to the population. They tended to be more educated than their employees. Thus, what matters may be the level of industrialization, the industrial structure, or the distribution of jobs types.

Third, international connectivity may be critically important. Portugal is not a city-state, but its location is close to rich Western European countries. Its strong agriculture, forestry, fishery, and diversified manufacturing are all export-oriented. This is at least one reason why this country could have managed to have a relatively high level of economic catch-up for its relatively low level of educational catch-up.

\subsubsection{The Quality of Education}

Since the late 1980s, economists have developed and used educational attainment data as an indicator of the human capital of economies. As an alternative indicator, Hanushek and his coauthors have developed country-level data of cognitive skills based on the results of 12 international student achievement tests conducted over the period from 1964 to 2003 (e.g., Hanushek and Woessmann 2012). ${ }^{4}$ Although the data are available only for 77 countries, most of which are high- or upper-middleincome countries, and of cross section as opposed to panel, Hanushek argues that this index captures the quality of education. The third column of Table 7.3 shows the cognitive skill index for the 29 emerging states listed in Table 7.2, while the first two columns of Table 7.3 shows GDP per capita and educational attainment (the quantity of education) as percentage of the US level. In this table, the countries are listed in the order of GDP per capita. As this table suggests, the cognitive skill index and

\footnotetext{
${ }^{4}$ These international student achievement tests include the Trends in International Mathematics and Science Study (TIMSS) and the Programme for International Student Assessment (PISA).
} 
Table 7.3 Data on major variables

\begin{tabular}{|c|c|c|c|c|}
\hline & (1) & (2) & (3) & (4) \\
\hline & $\begin{array}{l}\text { GDP per capita } \\
\text { as } \% \text { of US }\end{array}$ & $\begin{array}{l}\text { Attainment index } \\
\% \text { of US }\end{array}$ & $\begin{array}{l}\text { Cognitive skill } \\
\text { index }\end{array}$ & $\begin{array}{l}\text { Management } \\
\text { score }\end{array}$ \\
\hline Singapore & 138.8 & 94.5 & 533 & 2.861 \\
\hline Saudi Arabia & 91.8 & 69.9 & 366.3 & - \\
\hline Taiwan & 84.8 & 85.8 & 545.2 & - \\
\hline Korea & 67.1 & 96.5 & 533.8 & - \\
\hline Israel & 63.6 & 99.0 & 468.6 & - \\
\hline Poland & 48.1 & 89.4 & 484.6 & 2.887 \\
\hline Russia & 46.0 & 90.2 & 499.2 & - \\
\hline Kazakhstan & 44.8 & 85.3 & - & - \\
\hline Malaysia & 44.3 & 79.7 & 483.8 & - \\
\hline Chile & 41.3 & 81.9 & 404.9 & 2.752 \\
\hline Argentina & 38.7 & 79.1 & 392 & 2.699 \\
\hline Turkey & 36.8 & 62.9 & 412.8 & 2.706 \\
\hline Mexico & 30.3 & 71.9 & 399.8 & 2.899 \\
\hline Iran & 29.7 & 61.5 & 4219 & - \\
\hline Brazil & 28.4 & 73.8 & 368.3 & 2.684 \\
\hline Venezuela & 27.0 & 73.1 & - & - \\
\hline Thailand & 26.7 & 71.4 & 456.5 & - \\
\hline Algeria & 24.5 & 58.7 & - & - \\
\hline Columbia & 24.1 & 66.8 & 415.2 & 2.578 \\
\hline China & 23.9 & 66.3 & 493.9 & 2.712 \\
\hline South Africa & 23.2 & 71.9 & 308.7 & - \\
\hline Iraq & 23.1 & 59.7 & - & - \\
\hline Peru & 21.0 & 73.9 & 312.5 & - \\
\hline Egypt & 18.9 & 67.6 & 403 & - \\
\hline Indonesia & 18.6 & 63.3 & 388 & - \\
\hline Philippines & 12.7 & 71.1 & 364.7 & - \\
\hline Nigeria & 10.5 & 49.7 & 415.4 & 2.516 \\
\hline India & 10.0 & 55.2 & 428.1 & 2.611 \\
\hline Pakistan & 8.9 & 47.8 & - & - \\
\hline
\end{tabular}

Sources (1) PWT 9.0, (2) The human capital index of PWT 9.0, (3) Hanushek and Woessmann (2012, Table 11), (4) Bloom et al. (2017, Fig. 1)

Note The countries are arranged in order of GDP per capita

GDP per capita are closely correlated. Hanushek finds that the cognitive skill index is also closely correlated with income growth, and that this correlation is closer than that between the educational attainment index and income growth during the period 1960-2000. 
To see if Hanushek's finding holds true to a more recent period 2000-2014, the first column of Table 7.4 reports the result of regression analysis that includes both the cognitive skill index and the educational attainment index together with some control variables in a sample of the 67 countries for which data of all variables are available. The coefficient on the educational attainment index would be highly significant if the cognitive skill index were not included in the regression. Once the cognitive skill index is included, however, it becomes only marginally significant whereas the coefficient on the cognitive skill index is significant at the 5\% level, as shown in column (1). Column (2) shows that the latter coefficient is even more highly significant if the sample is replaced by a small sample of the emerging economies. As Hanushek (2012) claims, the level of cognitive skill or educational achievement seems to be a crucial component of long-run picture.

Does the quality of education matter to the middle-income trap? Column (3) of Table 7.3 shows this index for the 29 emerging states. According to Table 7.2, the majority of these states are trapped. The trapped states tend to have low values of the cognitive skill index..$^{5}$ Latin American countries, South Africa, and the Philippines have very low cognitive skills even though their attainment levels are not very low. Peru and South Africa score extremely low on cognitive skills. These observations indicate that the quality of education is more closely associated with the middleincome trap than the quantity of education.

Even if an emerging state is not in the trap, it may fall into the trap in future. The fate of such a county may depend largely on its current level of human capital. Egypt, India, Indonesia, Iraq, and Nigeria, are not diagnosed as being trapped, but they have considerably low educational attainment and achievement. It seems reasonable to suspect that they are prone to be caught in the trap unless they improve their education systems drastically.

\subsubsection{Educational Reform}

It is difficult to improve the quality of education. It was more difficult before than now because it was more difficult to identify what made the quality low. It was not clear how poor the quality was, the seemingly low quality could be attributed to the laziness of students, poor skills of teachers, low-quality curriculums, low salaries of teachers, poor management of schools, and so on. Today, an increasing number of counties participate in international student achievement tests, these difficulties are resolving today.

Still, the improvement of education quality remains difficult, probably because of mutually dependent interests among students and parents, teachers and schools, industries that employ graduates, and the government. In many countries, the gov-

\footnotetext{
${ }^{5}$ The index is designed so that its mean and one standard deviation among the OECD countries are equal to 500 and 100 , respectively. In the past, some countries succeeded in increasing their scores by $30-50$ points in 30 years. These achievements are admired by educators in other countries.
} 
Table 7.4 Association between education and growth of income per capital, 2000-2014

\begin{tabular}{|c|c|c|c|}
\hline & \multicolumn{3}{|c|}{$\begin{array}{l}\text { Dependent variable: average annual growth rate (\%) in GDP per } \\
\text { capita, 2000-2014 }\end{array}$} \\
\hline & (1) & (2) & (3) \\
\hline \multirow{2}{*}{$\begin{array}{l}\text { Log of real GDP per } \\
\text { capita in } 2000\end{array}$} & $-2.369 * * *$ & $-2.279 * * *$ & $-1.441 * *$ \\
\hline & $(-7.879)$ & $(-5.714)$ & $(-2.269)$ \\
\hline \multirow{2}{*}{$\begin{array}{l}\text { Resource rent \% of } \\
\text { GDP in } 2000\end{array}$} & $0.113 * * *$ & $0.102 * * *$ & $0.183 * * *$ \\
\hline & $(4.698)$ & $(4.495)$ & $(3.025)$ \\
\hline \multirow{2}{*}{$\begin{array}{l}\text { Educational } \\
\text { attainment in } 2000\end{array}$} & $1.039 *$ & 0.093 & -1.107 \\
\hline & $(1.775)$ & $(0.119)$ & $(-0.953)$ \\
\hline \multirow{2}{*}{$\begin{array}{l}\text { Cognitive skills } \\
\text { divided by } 100 \text { (mean) }\end{array}$} & $1.183 * *$ & $1.306 * * *$ & \\
\hline & $(2.291)$ & $(2.959)$ & \\
\hline \multirow{2}{*}{$\begin{array}{l}\text { Management score } \\
\text { (mean) }\end{array}$} & & & 3.829 \\
\hline & & & $(1.531)$ \\
\hline \multirow[t]{2}{*}{ Constant } & $17.251 * * *$ & $18.793 * * *$ & $8.365 *$ \\
\hline & $(7.632)$ & $(6.495)$ & (1.936) \\
\hline$N$ & 67 & 24 & 33 \\
\hline$R^{2}$ adjusted & 0.575 & 0.800 & 0.670 \\
\hline
\end{tabular}

Definitions and data sources:

- The real GDP is the expenditure-side real GDP at chained PPPs in million 2011US dollars. Its data are from Penn World Table (PWT 9.0, Feenstra et al. 2015)

- Resource rent is the total natural resource rent as a percentage of GDP. The data are from World Bank's World Bank Indictors

- Attainment index is the human capital index provided by PWT 9.0. It is based on Barro and Lee's (2013) data on years of schooling and an estimated rate of return to education

- The cognitive skill index is from Hanushek and Woessmann (2012, Table 11)

- The management score is from Bloom et al. (2017, Fig. 1)

Notes

- Numbers in parentheses are $t$-statistics. ***, **, and * indicate the statistical significance at the 1,5 , and $10 \%$ levels, respectively

- In columns (1) and (2), the initial GDP per capita has a negative and highly significant coefficient, which is a common result and suggests that hindrances to economic growth tend to be more powerful in higher income countries. The resource rent is included in the regression in order to control for the favorable impact of the natural resource price increase during the $2000 \mathrm{~s}$ on the economic growth of resource-dependent countries 
ernment is expected to coordinate the web of the tangled interests. Policy makers, however, might procrastinate rather than taking initiative since education reforms might require considerable time to become effective compared with their tenure. If they are willing, their capacity to coordinate may be limited. Moreover, the government's ability to finance and oversee the operation of public school systems might be limited.

Another difficulty arises from the fact that the importance of family input to early childhood development is not recognized by poor parents and their parents. This problem may be illustrated by an example from China. This country has vast rural areas where income levels are much lower than in urban areas. The economic gap between the two regions translates into the educational gap. A large number of parents, both fathers and mothers, in the inland region work in the urban region, leaving their children to their parents, who are unfamiliar with modern parenting and provide little input to young children's cognitive development. As a result, cognitive delays are alarmingly common in remote rural areas (e.g., Yue et al. 2016). In such areas, over $30 \%$ of lower-secondary school students drop out, and only $37 \%$ go to upper-secondary schools, while about $90 \%$ in large cities do (e.g., Kor et al. 2016). A substantial portion of youth population may fail to meet the skill requirements of upgraded industries. Urban people, however, are little interested in this problem, and the government has been slow to respond to it.

\subsubsection{Education and Income Inequality}

One might think that the government should reform education in order to mitigate regional inequality rather than let regional inequality make an education reform difficult. Indeed, the diffusion of knowledge and skills is widely believed to hold the key to economic equality. The central role in this process is played by education. Thus, education is reputed to be a major driver toward equal societies. The question arises, however, as to whether societies with higher education levels are more economically equal than societies with lower education levels. To answer this question, Fig. 7.3 plots the data of the Gini coefficient of income distribution within countries and the data of educational levels. ${ }^{6}$ We use Gini coefficient data in or around 2000, just before conditional cash transfer (CCT) programs were spread from Mexico to other Latin American countries, to make the following analysis simple. The $y$-axis measures the Gini coefficient. The $x$-axis measures the cognitive skill index in the upper panel or the educational attainment index in the lower panel.

\footnotetext{
${ }^{6}$ The Gini coefficient data are taken from the United Nations University-World Institute for Development Economics Research (UNU-WIDER) World Income Inequality Database WIID3.4, which offers multiple estimates of income inequality for each country. We use the estimates based on disposable or net income data collected from both urban and rural areas. If gross income data are used, the Gini coefficient tends to be high because redistribution is ignored. If data from only urban or rural areas are used, it tends to be low because the urban-rural gap is ignored.
} 

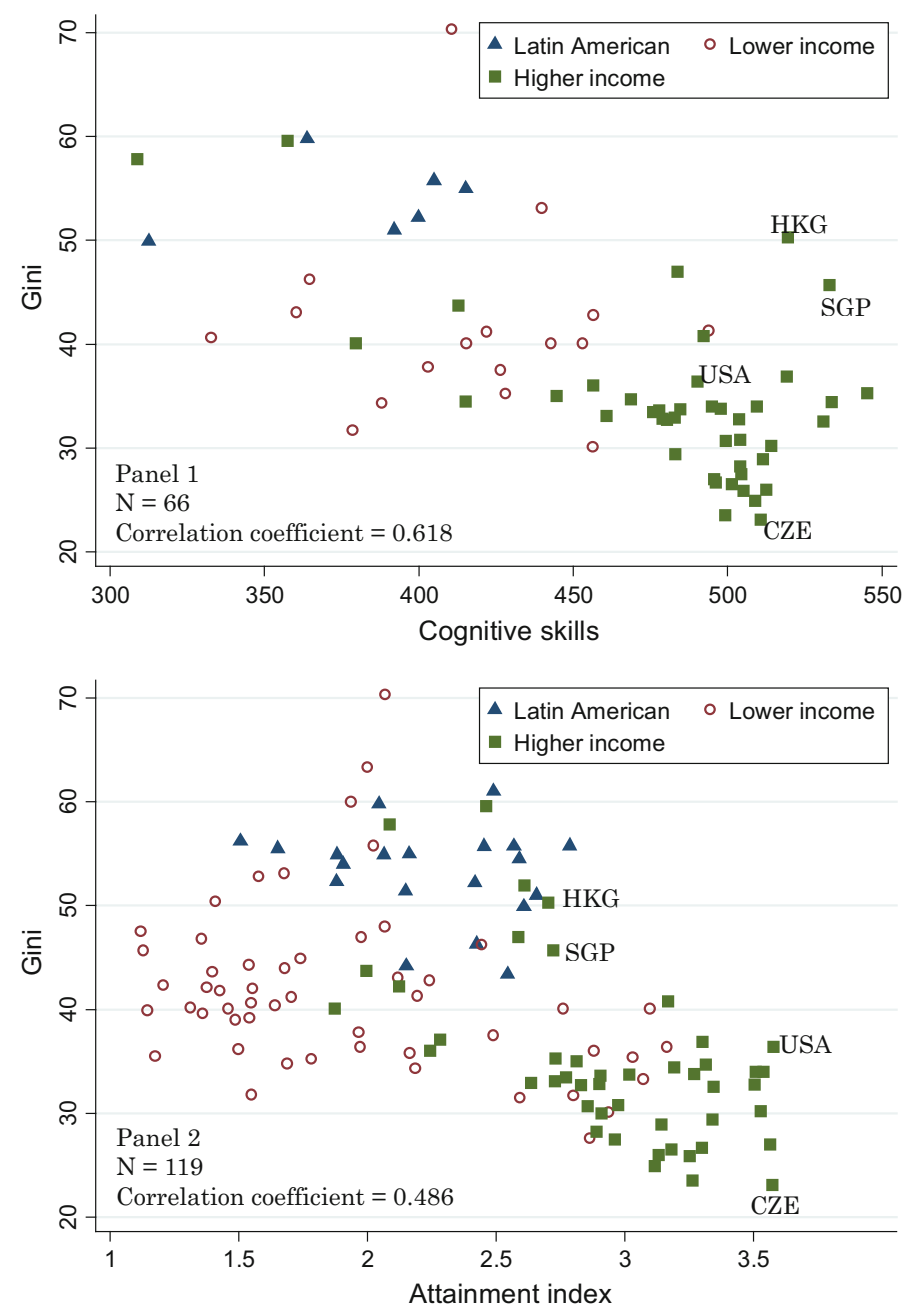

Fig. 7.3 Income inequality and education

Both panels show that education and income inequality are negatively correlated. In both panels, the negative correlation is statistically significant. However, it is not robust. For example, the correlation disappears from the upper panel if Latin American countries and two other countries, South Africa and Botswana, are excluded from the sample. In the lower panel, the negative correlation is not statistically significant among the low- and lower-middle-income countries. Among the upper-middle- and high-income countries, the negative correlation is highly significant, but it disappears completely if France, Germany, Switzerland, the Czech Republic, Finland, Canada, and Japan, which have highly established advanced social security and welfare systems as well as high levels of education. 
In Fig. 7.1, Boxes $\mathrm{H}$ and $\mathrm{E}$ are not just directly linked but also indirectly linked through Boxes I and P. The indirect linkages may offer an explanation why the correlation between education and inequality is not negative among relatively poor countries whereas it is negative among relatively rich countries. Consider an economy that is emerging but still relatively poor. Its accumulation of human capital and successful upgrading of its industries will inevitably create winners and losers. Winners include those who happened to have land titles in prospering economic centers, where land prices and rents soar, and those who happened to have connections with foreign technologies or export markets. Losers are those who cannot keep pace with rapid economic growth for any reasons. In relatively poor countries, losers tend to have no effective social safety nets, which might exist before urbanization and other social changes associated with rapid economic growth took place. Thus, as the red broken arrow indicates, industrial upgrading tends to increase inequality.

Due to the indirect effect, human capital accumulation alone might not lead to substantial reduction in inequality. Although social security and welfare programs would reduce inequality if effectively implemented, such a scenario was seldom realized in relatively poor countries because of the government's weak accountability and ability to finance such programs. The CCT programs in Latin American countries were successful to some extent, but their sustainability is unpredictable. In future, however, some of these countries may have political development of the type that took place in France, Germany, Switzerland, etc., leading to both highly advanced social welfare systems and high national levels of human capital, as mentioned above.

\subsection{Industrial Development and Upgrading}

\subsubsection{Drivers and Obstacles}

Openness and connectivity enhance trade and hence the division of labor between economies. Moreover, they enhance technology transfers and foreign investment. Their important roles in industrial development are best illustrated by the recent economic history of East and Southeast Asia. Japan liberalized trade in the late 1950s and then investment. Other Taiwan, Korea, Singapore, Malaysia, China, and Thailand followed suit in the 1970s and early 1980s, when most countries in South Asia, Africa, and Latin America still insisted in the inward oriented industrialization strategy. In the late 1980s, Indonesia and Vietnam began liberalizing trade and investment.

A number of firms in the East and Southeast Asian economies joined international production networks of Western and Japanese multinational firms as suppliers or vendors initially in those sectors that did not require a high level of quality control, such as garments and footwear of mass-production type. Gradually, however, an increasing number of firms in these regions produced electronic parts like basic types of printed circuit boards and assembled personal computers (e.g., Sonobe and Otsuka 2006). When the development of information and communication technology 
made the fragmentation of production process possible even in the automobile sector, these regions were ready to participate in automobile supply chains (e.g., Baldwin 2017). It is little wonder that many of the emerging states listed in Table 7.2 belong to these regions.

As a result of rapid economic growth they have enjoyed for an extended period, emerging states have seen wages soaring and their labor-intensive light manufacturing industries losing competitiveness. In many emerging states, moreover, only a small number of cities have good connection with foreign markets and technologies. As industries grew, these cities and especially the primary city grew into thriving and congested agglomerations of manufacturing and commercial activities. However, the problems of huge congestion, such as traffic jam, high rents, and pollutions, reduced the productivity of existing businesses and the probability that new profitable businesses emerge in large cities. In a sense, the result of growth in the past obstructs further growth.

To keep the high productivity of large agglomerations, congestion must be mitigated by developing transportation infrastructure within urban areas and by relocating production and commercial activities from the existing large agglomerations to the surrounding areas. For the latter purpose, industrial zones need to be built in suburban areas and rural areas and to connected with the existing large agglomerations and even export markets with highways, railroads, and sea- and airports. Such infrastructure development would require coordination of interests among stakeholders, such as central and local politicians and business persons in potential locations. It would also require coordination among central government ministries and local governments involved. The process of such coordination, planning, and implementation creates the risk of local captures and state captures of public resources. Thus, successful mitigation of urban congestion depends on the state capacity to manage the risk of state and local captures, to manage efficient operation of different parts of the government, and to coordinate conflicting interests (hence, the green solid arrow between Boxes P and I in Fig. 7.1).

New industries tend to be born in large economic agglomerations (that is, large cities and large industrial areas), where skilled workers, experts, and a variety of intermediate inputs are available and the market for new products is large (e.g., Henderson et al. 1995). As a result, industries tend to be concentrated in the economic center, and rural areas or periphery have relatively few thriving industries. Rural industries are fewer in lower income countries than in higher income countries. Thus, fact that agglomeration plays an important role in industrial development creates the problem of regional inequality or the problem of center and periphery, which is one of the reasons why the relationship between Boxes I and E in Fig. 7.1 is negative.

Rural industrial development is possible because some industries benefit little from large agglomeration but more from the availability of low-wage labor and spacious production site. Those industries with established supply sources, work force, and good reputation of its products and services may locate their production sites from large agglomeration to suburban or rural areas if infrastructure is developed. It is also be possible for rural areas to succeed in brand agriculture which produce and market high-value-added vegetables, horticulture products, dairy products, wine, and 
so on. Such successful development in rural areas, however, has been experienced only by some high-income economies. In emerging states, such development has not yet been observed. The government either turns a blind eye to regional inequality or takes care of it in the form of dole-out policies, such as pork-barrel projects, subsidies, and reduced taxes, which may be necessary to keep political stability but are costly.

As already mentioned in Sect. 7.3, industrial development creates vested interests (hence, the solid green arrow from Box I to Box U), but vested interests might interfere further industrial development (hence, the red dotted arrow from Box $U$ to Box I).

To summarize, openness, connectivity, and agglomerations have enhanced industrial development, which have in turn created urban congestion, regional inequality, and vested interests. A condition for avoiding the middle-income trap is to manage to keep the latter problems from decelerating economic growth too much and from causing political instability.

\subsubsection{Insufficient Responses to Higher Wage Rates}

This subsection asks how industries in emerging economies can counter the negative effect of increased labor costs. According to basic textbooks of economics, ordinary responses to an increase in wage rate are (i) substitution of expensive labor with capital, (ii) other cost reductions, and (iii) product upgrading. The substitution of labor with machinery would provide an opportunity for firms to upgrade their technology because newly imported machinery embodies relatively new technologies developed in advanced economies. To cut production costs, a firm would review the processes of processing, assembly, maintenance, inventory, and so on to eliminate wasteful uses of time, material, and energy. The firm might collaborate with its suppliers to improve the latter's productivity and lower intermediate input prices.

Upgrading products requires collaboration among a developer team, a production team, and a marketing team. The collaboration is coordinated by a manager. Consider a common case in which this manager is the head of the production team and hires the developer team and the marketing team. Developers and marketers may demand exorbitantly high rewards or sell the idea of the new product to other firms. If the expertise in product development and marketing is abundantly available, however, such opportunistic behaviors will be eliminated because troublemakers will be replaced by more conscientious experts. One of the advantages of agglomeration is considered to be abundance with experts.

In reality, however, developers and marketers as well as managers in emerging economies seem neither abundantly available nor well trained compared with their counterparts in high-income economies. The demand for expertise or skills in product development and marketing would be low in the past because firms could earn high profits without differentiating their products. Although managerial capabilities must have been used by every firm, but the recent economic literature offers two sets 
of evidence that managerial capabilities of firms in emerging states are rather low. First, small and medium enterprises in India and Vietnam are not familiar with standard management practices, such as lean or Kaizen management commonly used by American and Japanese firms, and their business performance improve after receiving management training or coaching from business consultants (e.g., Bloom et al. 2013; Sonobe and Otsuka 2014; Higuchi et al. 2015).

Another set of evidence for low managerial capabilities is provided by Bloom et al. (2017), who systematically obtained management information from 15,489 firms in 35 countries through interviews. Their measure of management practices, averaged over sample firms within countries, is distributed widely from 2.027 in Mozambique to 3.308 in the United States. The data are available for 11 out of the 29 emerging states and presented in column (4) of Table 7.3. Their average score, 2.718, is significantly lower than the average among high-income countries, 3.122.

Bloom et al. (2017) show that the national average of the management score is closely correlated with GDP per capita. How about its correlation with GDP per capita growth? Column (3) of Table 7.4 shows the result of growth regression that includes the national average of the management score. The estimated coefficient on this variable, 3.829, is not statistically significant, but its magnitude is considerably large. If the national average goes up by 0.5 points (so that an emerging state reaches parity with Germany), the GDP per capita growth rate rises by $1.9 \%$ points. Presumably the insignificance results from the small size of the sample; that is, if the management score were collected a greater number of countries, the estimate could become significant.

The large coefficient is consistent with a commonsense view that management matters to economic growth. With poor management, productivity and profitability are low, which makes it difficult to finance equipment investment and to hire experts in product development or marketing, and workers are not motivated or guided to learn new practices. Even the seemingly easy responses (i) and (ii) to rising wages, that is, substitution and other cost cutting, may be difficult in poorly managed firms.

The question arises as to why many firms are poorly managed. Bloom et al. (2013) find that owners of medium-scale textile firms in India do not hire any non-family members as managers because of lack of trust, and that firms can make profits without professional managers probably because they are protected from import competition by tariffs and from competition with new entrants by lack of external finance. There is empirical evidence that an increase in competitive pressure due to trade liberalization and deregulation increases the number of firms run by professional managers and improves management practices. ${ }^{7}$

In societies with social contestation, there may be another possible reason for poor management. In South Africa, "contestation between and within racial groups, with class and ethnic overlays has sharpened" recently, and it has been reflected in "workplace conflicts" and "a loss of economic productivity" among other things (Hino et al., forthcoming). This should have been captured by an arrow extending

\footnotetext{
${ }^{7}$ See, for example, Bandiera et al. (2015) and Chen and Steinwender (2017).
} 
from Box E to Box I, but it is missing in Fig. 7.1 because no empirical evidence for the effect has been presented even though there are suggestive anecdotes.

\subsubsection{The Role of Government in Industrial Upgrading}

In several ways, the government can help industries achieve upgrading. First, as discussed in Sect. 7.5.1, high quality education and economic agglomeration play important roles in industrial upgrading. The government can in principle improve the quality of education and mitigate urban congestion through infrastructure development. Second, the government can in principle increase competitive pressure on business owners through rigorous enforcement of competition policy, relaxation of entry regulation, and reduction of trade barriers, so that business owners are motivated to hire professional managers.

Third, the government can in principle support associations and non-profit organizations that establish qualification systems or ability-based grade systems, and those organizations that provide technology extension services and gather and distribute market information. The Industrial Technology Research Institute (ITRI) of Taiwan is one of the successful organizations that have played such roles (e.g., Sonobe and Otsuka 2006; Patarapong and Liu 2019). Fourth, the government can in principle be directly involved in research and development activities rather than supporting the efforts of the private sector.

These four types of policies are possible in theory, but their feasibility and effectiveness in reality depend on the government's administrative capabilities as well as the private sector's technological and managerial capabilities. Among these four types, the most difficult is of course the fourth policy. According to Lerner (2009), the vast majority of governments' attempts to boost innovations and entrepreneurship have failed around the world.

\subsection{Emerging States with Large Population and Territory}

Today's emerging states, especially BRICs (Brazil, Russia, India, and China), are among the largest countries in terms of population and territory. This section addresses the question of how the size of country affects the path of development and the policy that an emerging state adopts to avoid the middle-income trap.

\subsubsection{Similarities and Dissimilarities in Development Paths}

Industrial development in BRICs is cluster-based as in the emerging states in Southeast Asia and Japan, Korea, and Taiwan. In China, industrial clusters were few in 
number and small-scale during the period of command economy, but they mushroomed and burgeoned in Guangdong Province, Jiangsu Province, and Zhejiang Province after the start of the economic reform began. Industrial clusters continued to grow in size and number in the 1990s and 2000s in other parts of the territory. In the coastal region, they became strung together like beads to form economic agglomerations with population of several million people, which in turn constitute the so-called mega-regions, namely the Pearl River Delta, the Yangtze River Delta, and the Beijing-Tianjin-Hebei area. Each of these mega-regions has the world busiest container ports, such as Shenzhen, Hong Kong, and Guangzhou in the Pearl River Delta, Shanghai in the Yangtze River Delta, and Tianjin in the Beijing-Tianjin-Hebei area.

Incipient mega-regions are found in India. They surround the country's largest cities, such as New Delhi, Mumbai, Kolkata, Bengaluru, and Chennai, and grow rapidly in population and wealth by attracting migrants from rural areas and new businesses. These cities alone have more than 80 million residents. The size of economic agglomeration in China and India is an order of magnitude greater than that in the previously industrialized countries and the other emerging states.

A similar pattern of agglomeration was observed in Japan a half century ago. The rapid economic growth in that era was expected to slow down because of the severe congestion in each of the four major industrial zones that accounted for most of the industrial production in Japan. The remedy was the large-scale infrastructure development under the Income Doubling Plan implemented in the 1960s, which doubled real GDP per capita in seven years. The plan expanded the major industrial zones to suburbs and connected them with each other by highways and high-speed railways. Between the major industrial zones, new industrial zones with petrochemical industrial complexes or large-scale ironworks were built in sea-side districts to receive imported mineral resources and to produce basic materials such as plastic and iron and steel for machinery and other industries in the major industrial zones and other areas. As a result, the old and newly-built industrial zones and industrial cities as a whole formed what was called the Pacific Belt Zone, as they were located on the Pacific Ocean side of the country.

Each of the three mega-regions in China is at least as large as the Pacific Belt Zone in Japan. Note that these huge industrial complexes are clusters of industrial clusters and are located on the seashore. Thus, their successful industrial development is based on the benefits from large economic agglomeration and good connectivity to supply sources and markets. Thus, the logic of success was the same as we have discussed in Sect. 5.1 and common between China and Japan or between large and small emerging economies.

A major difference arising from the size of country is the attractiveness as investment destination. A country with large and growing population is more attractive as the destination of foreign direct investment than a small country, because the former is expected to grow into a large market in future whereas the latter can only be a production site for export. It is often a good idea for multinational firms to invest in a large country to establish their brand names before the market becomes large. If massive investment flows into a host economy, the latter will be boosted in the short 
run and in the long run, the latter will obtain learning opportunities useful for future industrial upgrading. For example, local managers employed by multinationals' local subsidiaries can learn standard management practices, and technology transfer from multinational firms to the host country may occur through foreign direct investment if the quality of engineering education is good in the host country. In these respects, large emerging states have advantage over their smaller counterparts. Indeed, China has succeeded in industrial upgrading in many industries, and Brazil and India seem to follow China's success.

Another important difference between large and small emerging states is the extent of regional inequality. In China, Brazil, and India, infrastructure development in remote rural areas is far behind. There is also large educational gap between urban and rural areas. It is easy to imagine that regional inequality can grow faster in gigantic countries than in countries with small territory. With low levels of infrastructure development and educational development, it is practically impossible for rural industrial development to take place. If China, Brazil, or India fell into the middle-income trap, the cause would not be the lack of industrial upgrading but political stability triggered by worsening inequality.

\subsubsection{Differences in Behavior}

A more notable difference between large and small emerging states is found in external engagement. BRICs are all nuclear nations, major military powers, and permanent members of the United Nations Security Council. Do they use their power for the purpose of avoiding the middle-income trap?

The leader of China proposed the Belt and Road Initiative in 2014 to build transportation, communication, water, and power systems to connect China, especially its inland provinces, with more than 60 countries through the Silk Road Belt and the Maritime Silk Road. It will reduce the regional inequality in China by offering construction worker jobs to the poor in the inland region, by improving connectivity and enhancing commercial activities in the region, and possibly by enhancing industrial development in the region as well. Although job creation for poor workers and improvement in connectivity are just a conventional combination, it is a novel idea to involve as many as 60 countries in domestic development. The idea makes sense because it seems possible to obtain commitments from many countries if not 60 .

In recent years, China has built islands and deployed troops in the South China Sea to back its expansive claim that the marine area is its own territory. This behavior may have an effect of taking attention away from inequality to the international issue. As a major military power, China has been promoting the development of artificial intelligence (AI) technology by the private sector in order to divert the technology to military use. The fruit of AI technology development will not just boost domestic industries, but it is also used by the government for surveillance activities intended to maintain political stability. Military-industry complex used to be observed only in high-income military powers. It would be an alien concept for small emerging states. 
Thus, the international bargaining power and military power put large emerging states in a better position to avoid the middle-income trap than small one, even though the difficulty in maintaining regional equality due to huge territory puts them in a worse position.

\subsection{Conclusion}

This chapter has found that it is difficult for middle-income countries, including emerging states, to become high-income countries in a timely manner. The economist tends to argue that the reason lies in the low ability of the private sector to upgrade products, productivity, and industrial structure. By contrast, the political scientist tends to think that industrial upgrading is difficult to take place because of resistance and interference of old firms that have political clout, and that industrial upgrading is difficult to continue because it creates winners and losers which in turn create conflict. Thus, political coordination is expected to be important, and political leadership is expected to play a critically important role in coordination.

To integrate these economic and political views of economic growth and middleincome trap, this chapter has developed a conceptual framework. It is designed to visualize relationships among human capital accumulation by households, industrial development in agglomerations through improved productivity and connectivity, rent-seeking and other unproductive activities of vested interests and protectionists, political development, economic growth, and equality and social cohesion. The power of this framework to generate meaningful hypotheses for empirical analysis will be judged by future studies.

Using this framework as a trial, this chapter made following arguments.

(1) Cross-country data suggest that the quality of education is closely associated with economic growth, but that it is not as closely associated with equality. Our framework suggests that the reason for the latter weak linkage is the negative impact of industrial development on equality.

(2) The recent literature has made it clear that the ability of firms to improve productivity depends much on their managerial capabilities. Unlike industries in low-income countries, those in the emerging states could easily to hire consultants and professional manages to improve managerial capabilities. Nonetheless, industrial upgrading is difficult to take place in the emerging states. Our framework suggests that the reason lies in the negative influence from vested interests and protectionism.

(3) Compared with small emerging states, large ones benefit from their abilities to develop mega-size agglomerations, to attract massive foreign investments, and to use strong international bargaining power. Our framework suggests, however, that they are even more prone to regional inequality, which might induce their leaders to resort to active or aggressive external engagement to keep popularity. 


\section{References}

Agénor, P. R. (2017). Caught in the middle? The economics of middle-income traps. Journal of Economic Surveys, 31(3), 771-791.

Baldwin, R. (2017). The great convergence: Information technology and the new globalization. Cambridge, MA: The Belknap Press of Harvard University Press.

Bandiera, O., Guiso, L., Prat, A., \& Sadun, R. (2015). Matching firms, managers, and incentive. Journal of Labor Economics, 33(3), 623-681.

Barro, R., \& Lee, J. (2013). A new data set of educational attainment in the world, 1950-2010. Journal of Development Economics, 104, 184-198.

Besley, T., \& Persson, T. (2010). State capacity, conflict and development. Econometrica, 78(1), $1-34$.

Bloom, N., Eifert, B., Mahajan, A., McKenzie, A., \& Roberts, J. (2013). Does Management Matter? Evidence from India. Quarterly Journal of Economics, 128(1),1-51.

Bloom, N., Sadun, R., \& van Reenen, J. (2017). Management as a technology? Working paper 22327 (issued in June 2016 and revised in December 2017). National Bureau of Economic Research.

Chen, C., \& Steinwender, C. (2017). Import competition, heterogeneous preferences of managers, and productivity. Working paper. Harvard Business School.

Feenstra, R. C., Inklaar, R., \& Timmer, M. P. (2015). The next generation of the Penn World Table. American Economic Review, 105(10), 3150-3182.

Felipe, J., Abdon, A., \& Kumar, U. (2012). Tracking the middle-income trap: What is it, who is in it, and why? Working Paper 715, Levy Economics Institute of Bard College.

Gill, I. S., \& Kharas, H. (2007). An East Asian renaissance: Ideas for economic growth. Washington, D.C.: World Bank.

Glawe, L., \& Wagner, H. (2017). The People's Republic of China in the middle-income trap? ADBI Working Paper Series No. 749. Asian Development Bank Institute.

Godo, Y. (2010). The human capital basis of the Japanese miracle: A historical perspective. In K. Otsuka \& K. Kalirajan (Eds.), Community, market and state in development. Basingstoke: Palgrave Macmillan.

Godo, Y., \& Hayami, Y. (2002). Catching-up in education in the economic catch-up of Japan with the United States, 1890-1990. Economic Development and Cultural Change, 50(4), 961-978.

Hanushek, E. A. (2012). Schooling, educational achievement, and the Latin American growth puzzle. Journal of Development Economics, 99(2), 497-512.

Hanushek, E. A., \& Woessmann, L. (2012). Do better schools lead to more growth? Cognitive skills, economic outcomes, and causation. Journal of Economic Growth, 17(4), 267-321.

Henderson, J. V., Kuncoro, A., \& Turner, M. (1995). Industrial development of cities. Journal of Political Economy, 103, 1067-1090.

Higuchi, Y., Vu, H. N., \& Sonobe, T. (2015). Sustained impacts of Kaizen training. Journal of Economic Behavior \& Organization, 120, 189-206.

Hill, H., Yean, T. S., \& Zin, R. H. M. (2012). Malaysia: A success story stuck in the middle? The World Economy, 35(12), 1687-1711.

Hino, H., Leibbrant, M., Machema, R., Shifa, M., \& Coudien, C. (forthcoming). Identity, inequality, and social contestation in the post-apartheid South Africa. In H. Hino, A. Langer, J. Lonsdale, $\&$ F. Stewart (Eds.), From divided pasts to cohesive futures? Reflections on Africa. Cambridge, MA: Cambridge University Press.

Im, F. G., \& Rosenblatt, D. (2013). Middle-income traps: A conceptual and empirical survey. Policy Research Working Paper Series 6594, The World Bank.

Kharas, H., \& Kohli, H. (2011). What is the middle income trap, why do countries fall into it, and how can it be avoided? Global Journal of Emerging Market Economies, 3(3), 281-289.

Kor, N., Pang, L., Liu, C., Chang, F., Mo, D., Loyalka, P., et al. (2016). China's looming human capital crisis: Upper secondary educational attainment rates and the middle-income trap. China Quarterly. Published online: 23 November 2016, 1-22. 
Lerner, J. (2009). Boulevard of broken dreams: Why public efforts to boost entrepreneurship and venture capital have failed - and what to do about it. Princeton, NJ: Princeton University Press.

Patarapong, I., \& Liu, M. C. (2019). Industrial technology upgrading and innovation policies: A comparison of Taiwan and Thailand. In K. Tsunekawa \& Y. Todo (Eds.), Emerging states at crossroad. Berlin: Springer.

Sonobe, T., \& Otsuka, K. (2006). Cluster-based industrial development: An East Asian model. Basingstoke: Palgrave Macmillan.

Sonobe, T., \& Otsuka, K. (2014). Cluster-based industrial development: KAIZEN management for MSE growth in developing countries (p. 2014). Basingstoke: Palgrave Macmillan.

Yue, A., Yang, S., Chen, J., Garth, J., Zhang, J., \& Medina, A., et al. (2016). Rural infant caregiver attitude, parenting behavior, and developmental delays in children aged 18-30 months: Finding from poor counties. Working Paper 307, Rural Education Action Program, Freeman Spogli Institute for International Studies, Stanford University.

Open Access This chapter is licensed under the terms of the Creative Commons AttributionNonCommercial-NoDerivatives 4.0 International License (http://creativecommons.org/licenses/bync-nd/4.0/), which permits any noncommercial use, sharing, distribution and reproduction in any medium or format, as long as you give appropriate credit to the original author(s) and the source, provide a link to the Creative Commons license and indicate if you modified the licensed material. You do not have permission under this license to share adapted material derived from this chapter or parts of it.

The images or other third party material in this chapter are included in the chapter's Creative Commons license, unless indicated otherwise in a credit line to the material. If material is not included in the chapter's Creative Commons license and your intended use is not permitted by statutory regulation or exceeds the permitted use, you will need to obtain permission directly from the copyright holder.

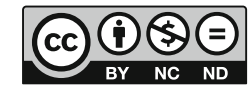

